\title{
Health promotion in migrants and older adults : epidemiological diagnosis, intervention development and effect evaluation
}

Citation for published version (APA):

Kocken, P. L. (2000). Health promotion in migrants and older adults : epidemiological diagnosis, intervention development and effect evaluation. [Doctoral Thesis, Maastricht University]. Universiteit Maastricht. https://doi.org/10.26481/dis.20000211pk

Document status and date:

Published: 01/01/2000

DOI:

10.26481/dis.20000211pk

Document Version:

Publisher's PDF, also known as Version of record

Please check the document version of this publication:

- A submitted manuscript is the version of the article upon submission and before peer-review. There can be important differences between the submitted version and the official published version of record.

People interested in the research are advised to contact the author for the final version of the publication, or visit the DOI to the publisher's website.

- The final author version and the galley proof are versions of the publication after peer review.

- The final published version features the final layout of the paper including the volume, issue and page numbers.

Link to publication

\footnotetext{
General rights rights.

- You may freely distribute the URL identifying the publication in the public portal. please follow below link for the End User Agreement:

www.umlib.nl/taverne-license

Take down policy

If you believe that this document breaches copyright please contact us at:

repository@maastrichtuniversity.nl

providing details and we will investigate your claim.
}

Copyright and moral rights for the publications made accessible in the public portal are retained by the authors and/or other copyright owners and it is a condition of accessing publications that users recognise and abide by the legal requirements associated with these

- Users may download and print one copy of any publication from the public portal for the purpose of private study or research.

- You may not further distribute the material or use it for any profit-making activity or commercial gain

If the publication is distributed under the terms of Article $25 \mathrm{fa}$ of the Dutch Copyright Act, indicated by the "Taverne" license above, 


\section{Health promotion in migrants and older adults}

Epidemiological diagnosis, intervention development and effect evaluation 



\title{
Health promotion in migrants and older adults
}

\author{
Epidemiological diagnosis, intervention development and effect evaluation
}

\section{PROEFSCHRIFT}

ter verkrijging van de graad van doctor aan

de Universiteit Maastricht, op gezag van de Rector Magnificus,

Prof.Dr. A.C, Nieuwenhuijzen Kruseman, volgens het besluit van

het College van Decanen, in het openbaar te verdedigen op

vrijdag 11 februari 2000, om 14.00 uur

door Paulus Leonardus Kocken 


\section{Promotores:}

Prof.dr. G.J. Kok

Prof.dr. F. Sturmans

\section{Beoordelingscommissie:}

Prof.dr. H.W. van den Borne (voorzitter)

Prof.dr. J.A. Knottnerus

Prof.dr. P.J. van der Maas (Erasmus Universiteit Rotterdam)

Prof.dr. Th. Paulussen (Katholieke Universiteit Nijmegen)

Prof.dr. H. de Vries

Part of the studies presented in this thesis was conducted with financial support from the Dutch Ministry of Health, Welfare and Sport (Commissie Determinanten van Gezondheid) and the AIDS fund (Programma Coördinatiecommissic Aids-onderzoek).

GGD Nederland, GGD Rotterdam e.o, and Glaxo Wellcome financially supported the printing and distribution of this thesis.

\section{ISBN 90-9013473.5}

graphic production: Caroline Poot

printed by: Offsetdrukkerij Ridderprint b.s. Ridderkerk

photographs by: Joop Reyngoud and Jan van der Meijden 


\section{Voorwoord}

Dit proefschrift is de neerslag van 10 jaar werken bij de Gemeentelijke Gezondheidsdienst (GGD) Rotterdam e.o.. Het is een voorrecht om bij een dienst onderzoek te doen, waar 'evidence based public health' hoog in het vaandel staat. Aan planmatige gezondheidbevordering, ondersteund met onderzoek, wordt grote waarde gehecht. Daarbij staat niet het ontwikkelen van nieuwe wetenschappelijke theorieēn voorop, maar het toepassen van wetenschappelijke inzichten ten dienste van een betere gezondheidssituatie van de inwoners van Rotterdam. Het schrijven van een proefschrift in een dergelijke innovatieve en stimulerende omgeving zou eigenlijk als vanzelf moeten gaan. Echter, het ontwikkelen van gezondheidsbevorderingsprogramma's voor de Rotterdammers krijgt natuurlijk voorrang, in vergelijking tot wetenschappelijke discussie over het werk. Dat het uiteindelijk toch tot een proefschrift is gekomen, heb ik te danken aan de stimulerende inbreng van mijn promotores. Met Ferd Sturmans sloot ik een 'gentlemen's agreement' om over mijn werk te publiceren en de artikelen in een proefschrift te bundelen. Gerjo Kok heeft mij op inspirerende wijze ingewijd in de mogelijkheden en onmogelijkheden van gezondheidsvoorlichting en opvoeding. Zij hebben ervoor gezorgd dat dit proefschrift zijn uiteindelijke omvang én kwaliteit kreeg.

De artikelen in dit proefschrift zijn niet in de laatste plaats het produkt van plezierige samenwerking met velen. Zonder de inbreng van de co-auteurs, collega-onderzoekers, secretariaatsmedewerkers, steunpunten van seniorenvoorlichting en migrantenvoorlichting, en de voorlichters kon dit proefschrift niet worden voltooid. Graag zou ik iedereen in dit voorwoord persoonlijk bedanken, echter dit zou een eindeloze lijst opleveren. De dankbaarheid voor ieders inbreng is zeer gemeend.

Echter, zonder iemand tekort te willen doen, moet ik toch enkele uitzonderingen maken. Met Toon Voorham heb ik de laatste jaren intensief samengewerkt aan de evaluatie-onderzoeken van wat hij noemt 'de voor en door voorlichting'. Hij was de initiator van de onderzoeken naar seniorenvoorlichting en Aids-voorlichting in eigen taal en cultuur. Het was prettig om van Toon's rijke ideeēn kennis te nemen en ik hoop dat deze ideeën ook voor anderen toegankelijk worden.

Bij de techniek van het maken van dit proefschrift heb ik veel hulp gekregen van Miranda en Caroline. Miranda Aldham-Breary heeft het Engels steeds zeer zorgvuldig gecorrigeerd. Een bemoedigend woordje en 'social talk' waren voor Miranda nooit teveel. Caroline Poot verdient veel lof voor de lay-out en het ontwerp van het boek.

Mijn vader heeft mij regelmatig en soms tot vervelens toe gevraagd hoe het met 'de studie' stond. Helaas kan hij het eindresultaat niet meer bewonderen. Voor hem en mijn moeder heb ik het proefschrift afgemaakt. Tot slot dank ik Alex, die mij steeds duidelijk maakt en laat voelen dat er meer is op deze wereld dan de GGD.

\section{Paul Kocken}




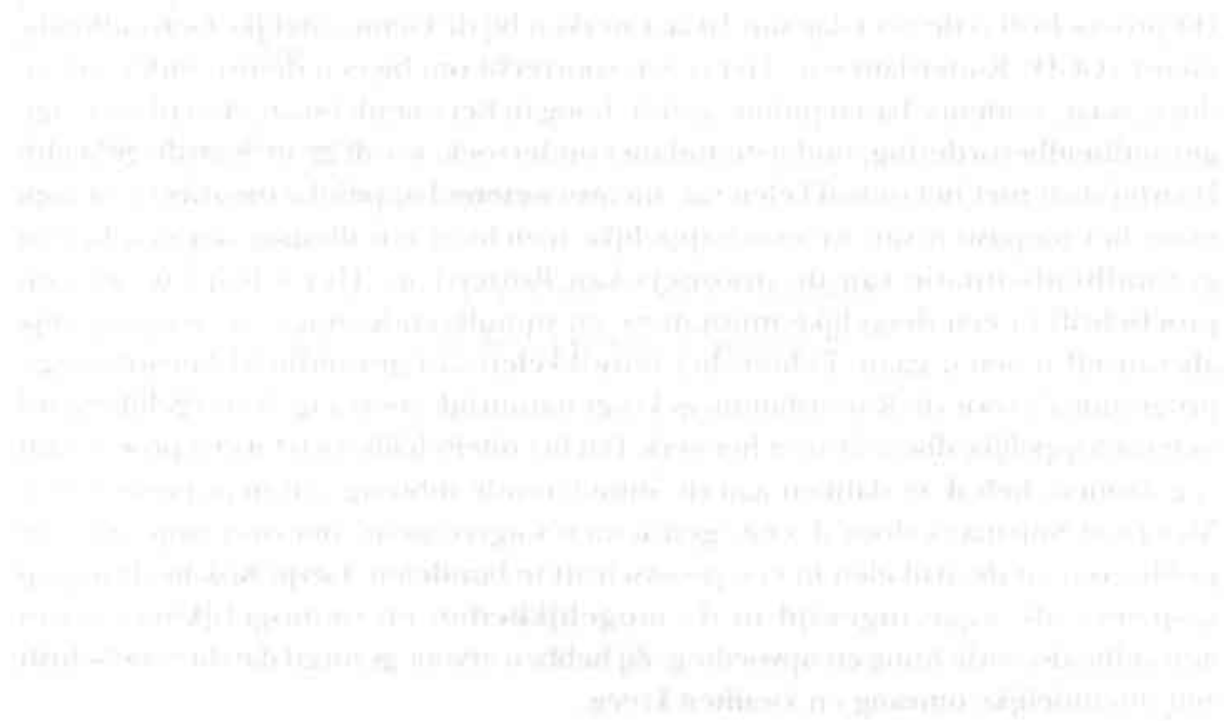




\section{Contents}

1. Health promotion planning ............................................................................... 3

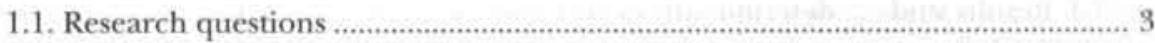

1.2. Health promotion planning: definitions …........................................................ 5

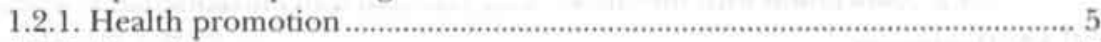

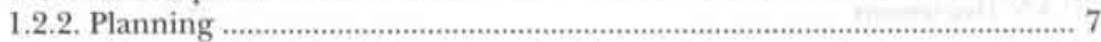

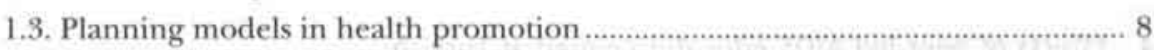

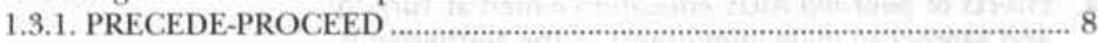

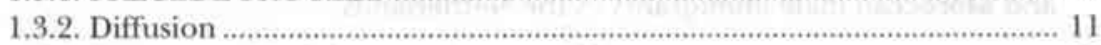

1.3.3. Community health promotion model .................................................... II

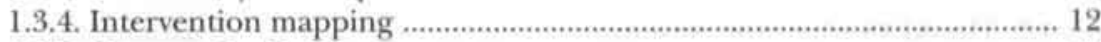

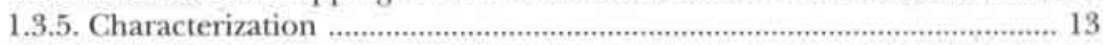

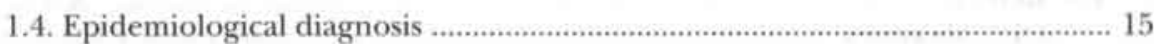

1.4.1. Descriptive and particularistic epidemiology ................................... 15

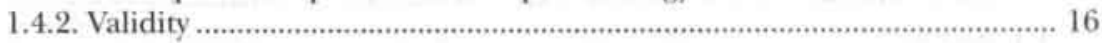

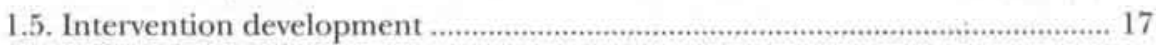

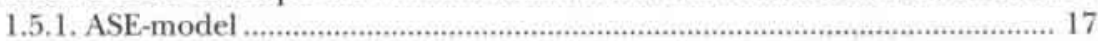

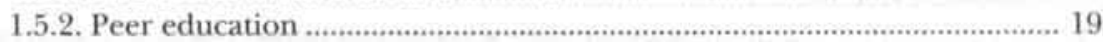

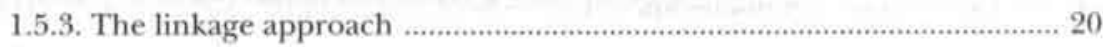

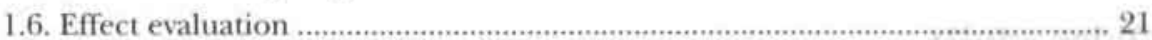

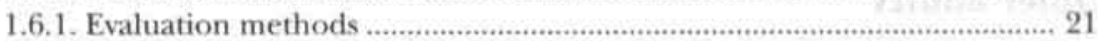

1.6.2. Methods used in the real life setting of a public health service .............. 23

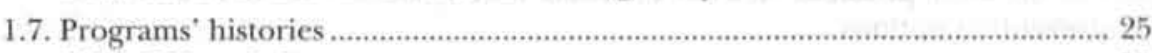

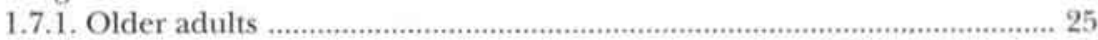

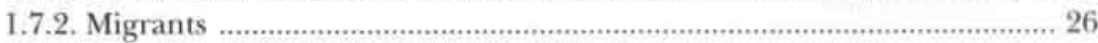

\section{Migrants}

2. Mortality, self-rated health and reported use of health care among the Rotterdam Surinamese ...................................................... 35

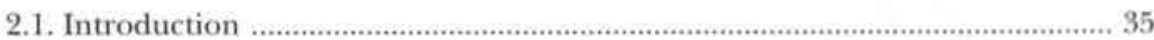

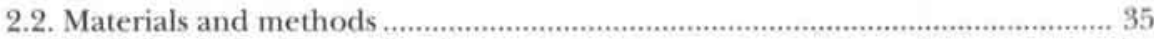

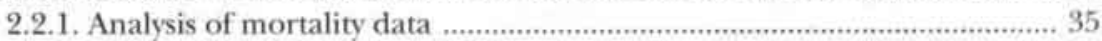

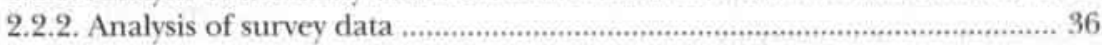

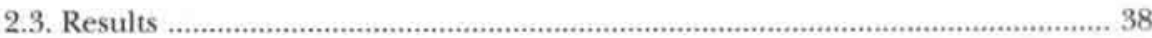

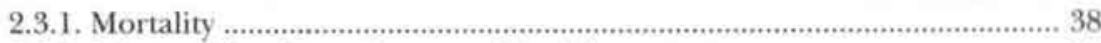

2.3.2. Self-rated health and reported health care use ..................................... 39

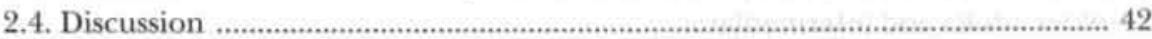

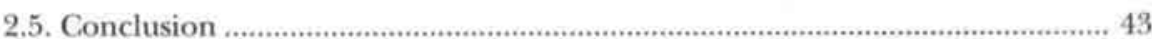

3. Peer-led AIDS education aimed at Turkish and

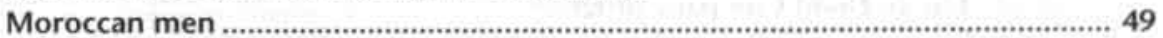

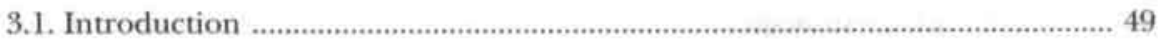


3.2. Methods and materials .................................................................................. 50

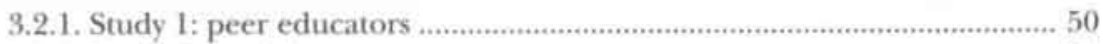

3.2.2. Study 2: participants ......................................................................... 50

3.3. Results study 1: the AIDS education objectives ............................................. 53

3.4. Results study 2: determinants of condom use ................................................... 54

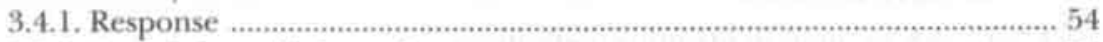

3.4.2. Association with intention ..................................................................... 55

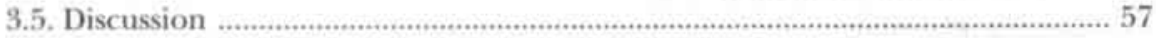

4. Effects of peer-led AIDS education aimed at Turkish and Moroccan male immigrants in the Netherlands ............................................63 63

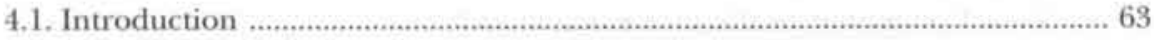

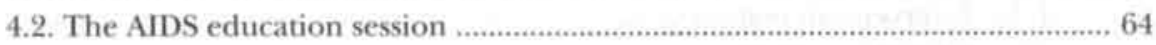

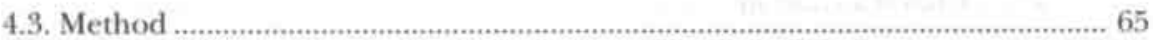

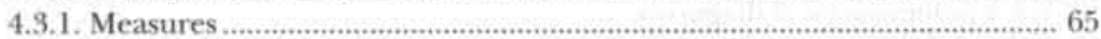

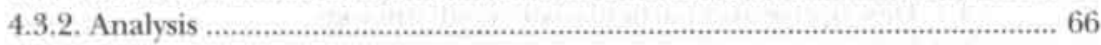

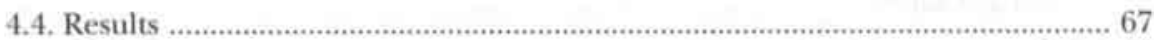

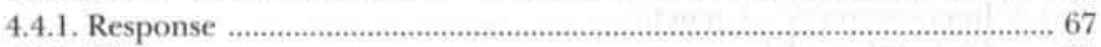

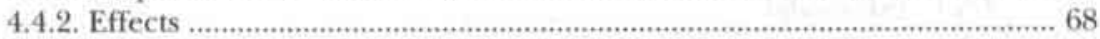

4.5. Conclusion and discussion ............................................................................. 71

\section{Older adults}

5. Psycho-social problems in the Rotterdam elderly and prevention options .............................................................................................. 79

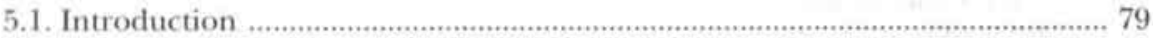

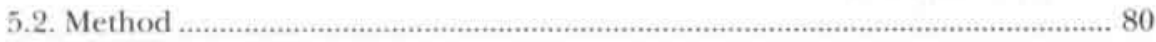

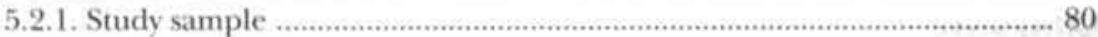

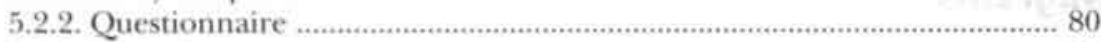

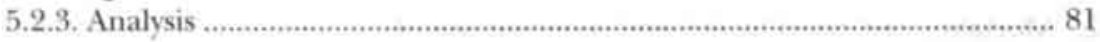

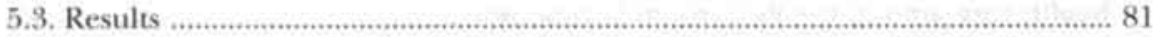

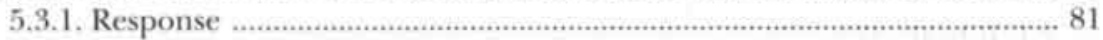

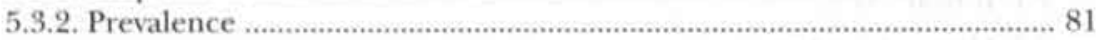

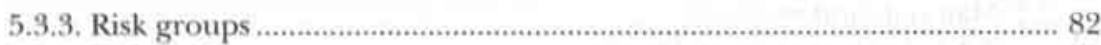

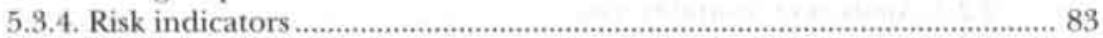

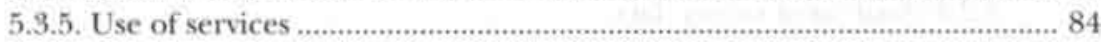

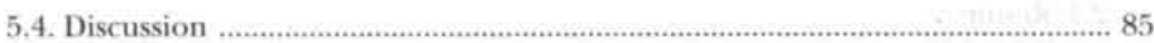

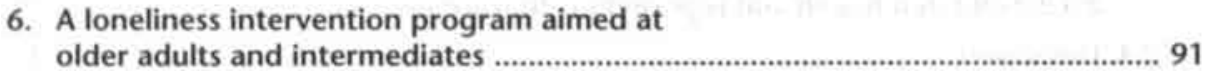

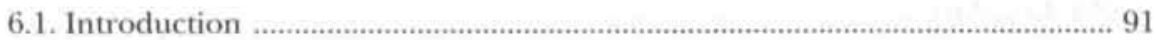

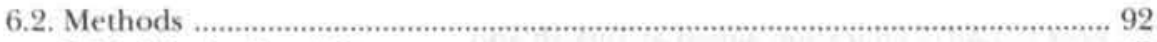

6.2.1. The In Good Company program ............................................................ 92

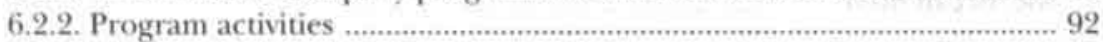

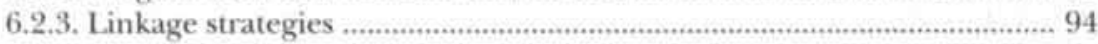




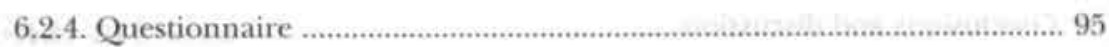

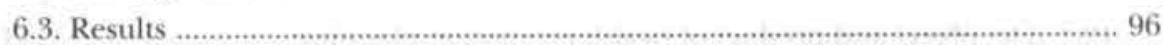

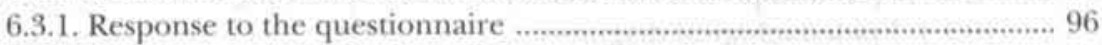

6.3.2. Opinions and satisfaction of intermediates ............................................. 96

6.4. Discussion and conclusion ......................................................................... 98

7. Interest in participation in a peer-led senior health

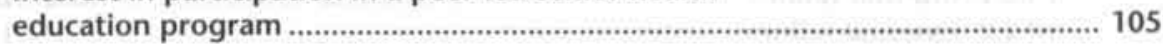

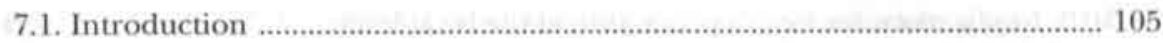

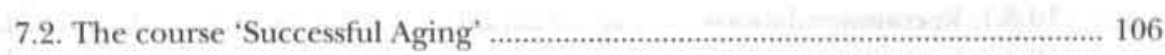

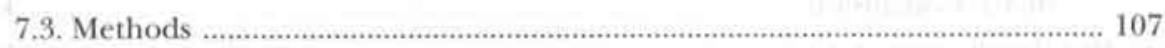

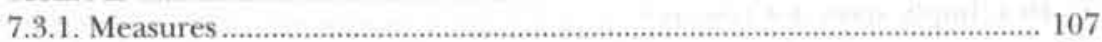

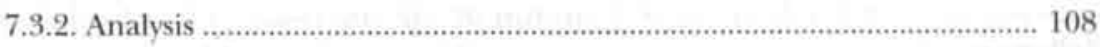

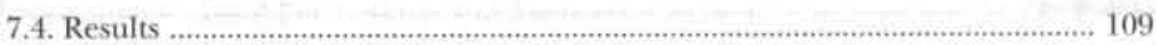

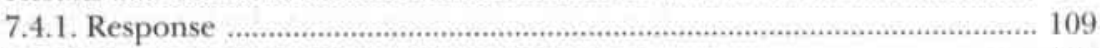

7.4.2. Characteristics of interested respondents ............................................ 109

7.4.3. Rates of expressed interest in the population .................................... 109

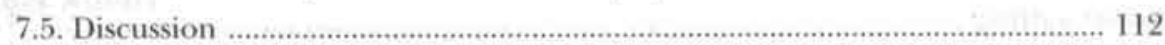

8. Effects of a peer-led senior health education program ................................. 121

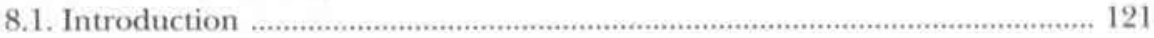

8.2. Outline of the course 'Successful Aging' ..................................................... 122

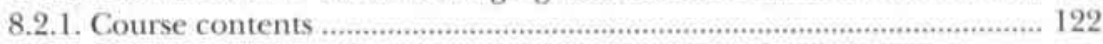

8.2.2. Behavioural model ........................................................................ 122

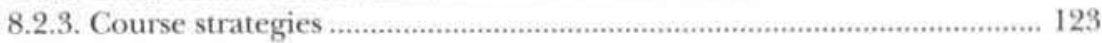

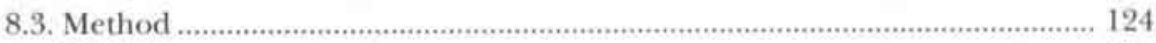

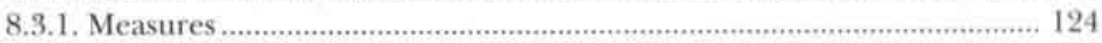

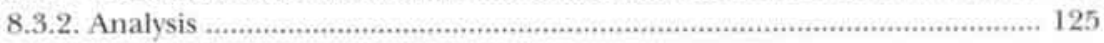

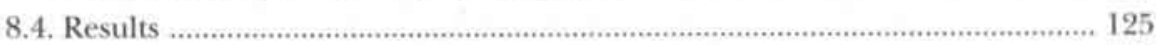

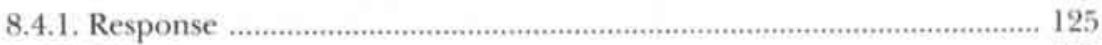

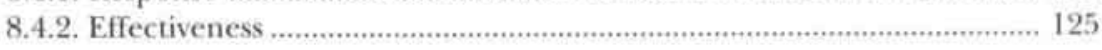

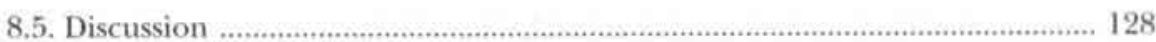

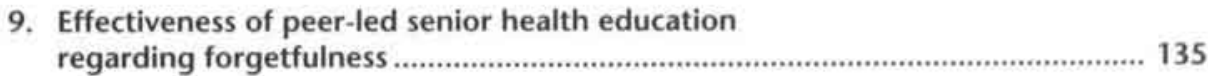

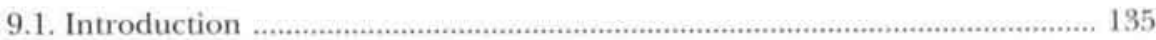

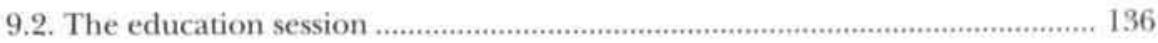

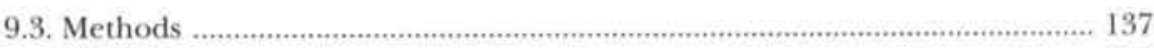

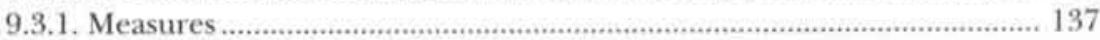

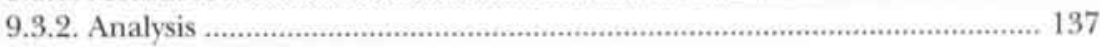

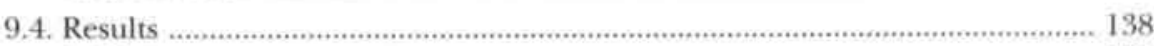

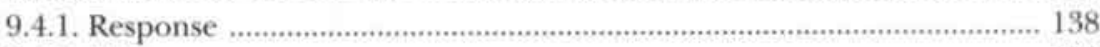

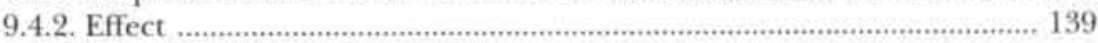

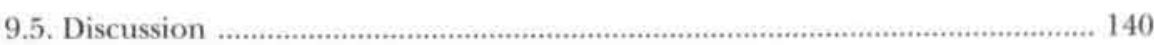


10.1. The object and product of health promotion planning .............................. 147

10.1.1. Epidemiological diagnosis ............................................................. 147

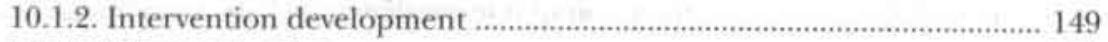

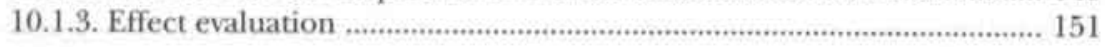

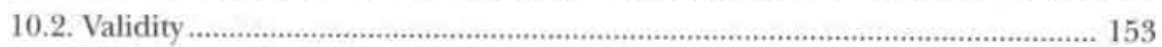

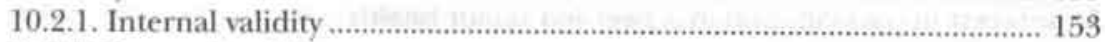

10.2.2. External validity ............................................................................. 155

10.3. Implications for health promotion at the local level ................................... 156

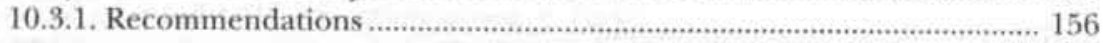

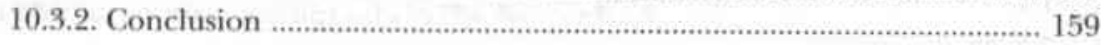

10.4. Implications for research ......................................................................... 161

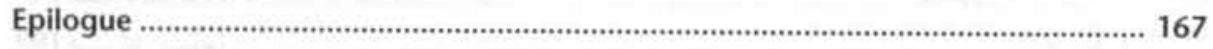

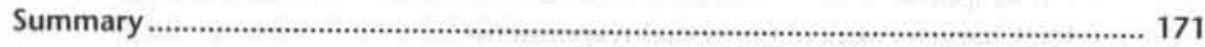

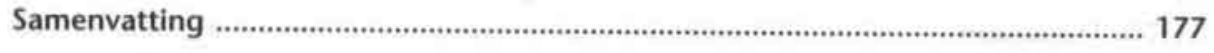

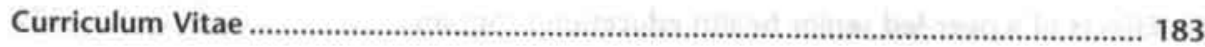




\section{Original articles}

\section{Migrants}

Chapter 2. Kocken PL, Mackenbach JP, Oers JAM van, Uniken Venema HP. Sterfte, ervaren gezondheid en gerapporteerd voorzieningengebruik van Rotterdams Surinamers. TSG 1994;72;231-236.

Chapter 3. Kocken P, Voorham T, Haastrecht P van. AIDS-voorlichting voor en door Turkse en Marokkaanse mannen: doelstellingen, determinanten en praktijk. Submitted.

Chapter 4. Kocken PL, Voorham AJJ, Brandsma J, Swart WAJM. Effects of peer-led AIDS education aimed at Turkish and Moroccan male migrants in the Netherlands: a randomized controlled evaluation study. Submitted.

\section{Older Adults}

Chapter 5. Kocken PL, Klaus-Meijs WMM. Psycho-sociale problemen van ouderen in Rotterdam en aanknopingspunten voor preventie. Tijdschrift voor Gerontologie en Geriatrie 1993;24:137-142.

Chapter 6. Kocken P. A loneliness intervention program aimed at older adults and intermediates: linkage of program plans and users' needs. Submitted.

Chapter 7. Kocken PL, Voorham AJJ. Interest in participation in a peer-led senior health education program. Patient Education and Counseling 1998;34:5-14.

Chapter 8. Kocken PL, Voorham A]J. Effects of a peer-led senior health education program. Patient Education and Counseling 1998;34:15-23.

Chapter 9. Kocken PL, Voorham AIJ. Effectiviteit van seniorenvoorlichting over vergeetachtigheid. TSG 1998;76:323-329 


\section{Chapter 1}

Health promotion planning

epidemiological diagnosis

intervention development

effect evaluation 
[1 Mychish

Eniminglin noisomasq itylegth 


\section{Health promotion planning}

Health promotion planning guides the daily routine of a public servant, working at a local public health service, and although he might sometimes believe that his work disappears in an uncontrollable flow of decision making processes, a planning effort can be discovered from a more removed point of view. Public health officers from several disciplines contribute to improve the quality of life for communities. Epidemiologists conduct studies among citizens to bring health problems at the surface, health promotion workers develop programs to encourage healthy lifestyles and environments, administration officers contribute to governmental policy making, and research scientists evaluate programs and policies aimed at changing unhealthy behaviours and environments. This thesis comprises a number of empirical studies in support of health promotion in migrants and older adults. The process of health promotion is not examined as such, however the planning steps of health promotion provide a framework that can be used to understand better research conducted in a public health service setting.

The planning of health promotion is explained in this chapter. Firstly, the research questions of this thesis are described. Definitions of health, health promotion and planning are given in section 1.2. Several health promotion planning models are reviewed in section 1.3. The planning elements focused on in this thesis, i.e. epidemiological diagnosis, intervention development and effect evaluation are treated in sections 1.4 to 1.6. A chronological overview is given of the contents of the empirical part of this thesis in section 1.7 .

\subsection{Research questions}

Health promotion is defined as any planned combination of educational, political, regulatory, and organizational supports for actions and conditions of living conducive to the health of individuals, groups, or communities. 'An important characteristic of health promotion mentioned in this definition is the planned development and provision of activities. Decisions on the design of health promotion interventions are grounded thoroughly in knowledge of the health problems and theories on effective behavioural and organizational change. The definition of health promotion will be explained in more detail in the following section.

Planning is viewed in this thesis as a system comprising the elements or subsystems, gaining insight, making decisions and taking action. ${ }^{2} \mathrm{~A}$ system is a meaningful set of separable subsystems which are linked in such a way that no element is isolated. ${ }^{3}$ Departments of an organization, components of computer hardware, parts of an engine often are described as a system, however a system also applies to abstract elements of a (planning) theory. The interconnectedness of the system elements or subsystems can be divided into aspectsystems. ${ }^{3}$ In this thesis the aspectsystems object, process and product are distinguished. ${ }^{4.3}$ Object refers to the theme or problem on which gaining insight, making decisions or taking action are focused. What is studied, 
decided upon or implemented? Process refers to how a theme or problem is studied, decided upon or implemented. Product refers to the outcome or solution of gaining insight, making decisions or taking action. Another dimension or aspectsystem of health promotion planning is the target group the subsystems of planning deal with, and in this thesis the central aspectsystems are migrants and older adults.

Three elements of the subsystems of health promotion planning, i.e, sub-subsystems epidemiological diagnosis as element of gaining insight, intervention development as element of decision making and effect evaluation as an element of taking action are focused on in this thesis, with an emphasis on the aspectsystems, object and product of planning. The process of how the planning of health promotion comes about was not studied.

The main research question was:

What is the object and product of epidemiological diagnosis, intervention development and effect evaluation in health promotion planning, aimed at migrants and older adults?

The articles that are included in this thesis address the following research questions.

\section{Migrants}

\section{Epidemiological diagnosis}

1. Are there differences in mortality, subjective health and reported health care use between the Surinam and autochthonous citizens of Rotterdam? Can a difference in subjective health and reported health care use be explained by the educational level and work situation of the respondents?

\section{Intervention development}

2. What were the objectives of peer-led AIDS education for male Turkish and Moroccan men? What are determinants of condom use by Turkish and Moroccan men?

\section{Effect evaluation}

3. What is the effect of peer-led AIDS education, aimed at male Turkish and Moroccan immigrants, on the perceived threat of AIDS and beliefs about condom use?

\section{OIder adults}

\section{Epidemiological diagnosis}

4. What is the prevalence of psycho-social problems in elderly Rotterdam citizens living independently? Which groups are at risk regarding psycho-social problems? What are the risk indicators of psycho-social problems? What is the association between psycho-social health and use of services? 


\section{Intervention development}

5. What was the linkage approach used in the In Good Company program carried out in three experimental Rotterdam neighbourhoods? Which linkage approach enhanced the satisfaction of the intermediates with the program and contributed to successful dissemination?

6. Which subgroups of older adults expressed interest in the health education course Successful Aging? What were the characteristics of those who actually inscribed for the course? What were the rates of expressed interest among the subpopulations? Was the dissemination strategy that was used suitable?

\section{Effect evaluation}

7. Was the course Successful Aging effective in improving social participation, the determinants of social participation, social support and wellbeing of its members?

8. What was the effect of the education session dealing with forgetfulness in the course Successful Aging on knowledge, attitude, self-efficacy and social influence regarding anxiety about normal forgetfulness?

\subsection{Health promotion planning: definitions}

\subsubsection{Health promotion}

Health education and health promotion are relatively new fields of study in the social and health sciences. Most scientific journals covering this area were founded in the $1970 \mathrm{~s}$. Theories and insights into processes of behavioural and environmental change are evolving strongly, and doing research in this developing area is an exciting pursuit. The scope of interest of scientists has broadened from health education to health promotion. Health education has been defined by Green e.a. as 'any designed combination of methods to facilitate voluntary adaptions of behaviour conducive to health'. ${ }^{5}$ The emphasis of health education is on learning experiences. For instance, educating people about family planning and contraception has to be distinguished from offering financial incentives when people limit their family size.' Health education pursues voluntary behaviour changes." The individual learns from the health message and is free to reject the plea for behaviour change. Another characteristic of health education is that it has been defined by its expected outcome: adaption of behaviour as an act of change. Health education is not defined by the methods used. Group processes, television, counselling, all educational methods are suitable, as long as they are designed to change behaviour in the desired direction. 3

The World Health Organization (WHO) definition of health is used in this thesis: a state of complete physical, social and mental wellbeing, and not merely the absence of disease or infirmity. ${ }^{7}$ This definition is interchangeable with the definition of quality of life which includes physical, social and mental health. ${ }^{8}$ Professionals in health education gradually became aware that people's health status is affected by their 
behaviour and by factors in the environment of an individual. Societal norms and values, economic constraints, living conditions (housing, pollution) and the accessibility of health care services are external factors, which are important, directly and indirectly, to personal health..$^{9,10}$ External factors, like environmental pollution, can influence people's health directly. In an indirect way, having the disposal of sufficient income or acceptable housing enables people to adopt and maintain a healthy lifestyle. These environmental conditions are often unentangable for individuals. Moreover, they are beyond the influence of the health field. Health educators therefore came to the conclusion that influencing policy making and mobilizing citizens to take control over their environment should be added to their strategy to change the quality of life. Health promotion has been defined as any planned combination of educational, political, regulatory, and organizational supports for actions and conditions of living conducive to the health of individuals, groups, or communities. Factors in the environment are discussed in this thesis, only when they indirectly hinder or facilitate behavioural change.

Figure 1 illustrates the characteristics of health education and health promotion. ${ }^{1}$ The diagram makes clear that health promotion encompasses health education. The first characteristic pertains to responsibility. Health change is not the responsibility of the individual alone. Health education can make people aware of their responsibility to look after their health, however society has to enable people to make a healthy choice. Health education facilitates behavioural change of individuals, moreover the objective of health promotion is ecological change. This means that health promotion not only encompasses promoting health for people, but also looks at town infrastructure (healthy cities) and deals with policy makers (healthy policy) to produce healthy lifestyles. Health promotion recognizes that it is not only the victim that is to blame, the individual's control over behaviour is limited. Behaviour is also conditioned by societal circumstances, values and economical constraints. A characteristic of health promotion is that it includes conscious health directed behaviour, as well as unconscious behaviours and lifestyles that are socially embedded and do not promote health.'

- Figure 1. Health education and health promotion

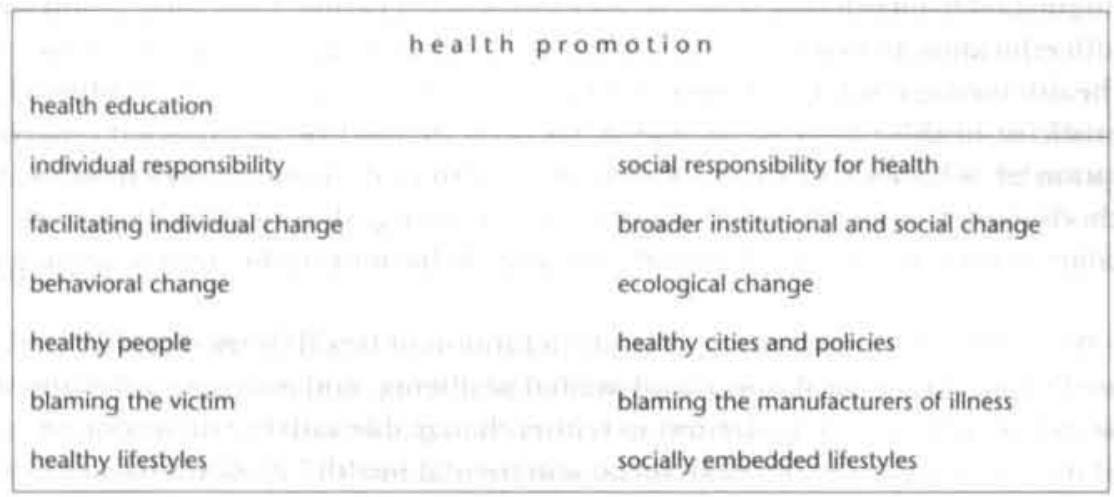

(Source: Green LW, Kreuter MW. Health promotion planning: an educational and environmental approach. 2nd ed. Mountain View: Mayfield, 1991) 
Health education is usually embedded in health promotion programs as figure 1 indicates, rather than existing as an autonomous, free-standing activity. Two other kinds of activities of health promotion should be mentioned: facilitation and advocacy. Facilitation concerns action taken in partnership with individuals or social groups to mobilize human and material resources for health. "Health education and health promotion have a facilitative role. The facilitative role applies to community action and to empowerment of individuals and communities to pursue healthy living conditions. Health education facilitates behavioural change in individuals, moreover health promotion facilitates, when necessary, change in organizational conditions or societal opinion. Advocacy is defined as action taken on behalf of individuals and/or communities to overcome structural barriers to the achievement of health. ${ }^{11}$ Health promotion professionals often function in an infrastructure from where access to policy making or contact with professionals outside the health care field is easier realized. They are the advocates of citizens who often do not know their ways in the complex administrative and institutional procedures. The advocatory role goes beyond the boundaries of health promotion, however these boundaries are not always clear. ${ }^{\text {note } 1}$ The question can be raised whether, for instance, administration of health care facilities or engineering of the physical environment are part of health promotion. Positive health as defined by the WHO, is not only determined by people's individual behaviour, but also by structures and policies outside the health field. ${ }^{10,12}$ All actions, whether they are within the field of preventive health care or not, are included in the broad definition of health promotion, e.g. income policy and city planning. Green adheres a more limited definition of health promotion, directed primarily at behavioural change. ${ }^{13}$ Behavioural change is in his view the focal point of health promotion, and environmental changes and health care actions that enable and reinforce people's healthy lifestyles are included. Preventive actions directed at the physical environment are called health protection, and interventions directed at the health care system are referred to as preventive health services. ${ }^{13}$ (Green, 1990) The grip of health educators or health promotion officers, working for public health services, on these fields is limited, instead they have an advocatory function. The more limited field of health promotion is focused on in this thesis, i.e. health education and interventions enabling and sustaining healthy behaviour, without disregarding the importance of effective health care services and health protective distribution of physical, chemical and biological resources.

\subsubsection{Planning}

Health promotion workers face the comprehensive task of collecting knowledge of social and epidemiological problems, preparing interventions, influencing policy making, having communities participate, and evaluating interventions. These actions have to be organized and planned. Many definitions of planning exist. The following two definitions give an illustration of how planning can be understood:

Planning is the process of preparing a set of decisions for action in the future, directed at achieving goals by preferable means. ${ }^{14}$ 
Planning is the combination of gaining insight, making decisions and taking action, and the interconnection between these three elements. ${ }^{2}$

The second definition of planning given above is used in this thesis. The planning subsystem gaining insight is included in both definitions. Planning is limited in the first definition to the preparation of decisions and actions in future. The second definition uses a different time perspective, decisions on courses prepared in advance of action, and execution of the decisions are included. Recognition of action as a planning component follows the opinion that plans are not fulfilled automatically. Special attention has to be paid to the process of implementing the actions designed beforehand. The idea that implementation is the logical result of carefully designed plans represents the classical approach to planning, in which the execution of a plan is seen as a managerial problem. A modern approach to the action element of planning is the opinion that implementation is a process dependent on negotiation and execution of power by the actors involved. ${ }^{13}$

\subsection{Planning models in health promotion}

Several different health promotion planning models have been developed. The three planning elements, gaining insight, making decisions and taking action are described in the models. These three elements of planning usually do not follow each other successively. The program planner moves back and forth from one stage to another. Planning is a circular, iterative process, with different points of departure and interaction between the stages. For example, decisions on program targets and target groups are taken during the process of gaining insight, and decisions on the program often are directed by evaluations that give insight into the attainment of program objectives. ${ }^{\text {th }}$ Planning models that are commonplace in health promotion are discussed in this section. The models are described using the three subsystems of planning, i.e.gaining insight, making decisions and taking action. Accents on the three subsystems and on the aspectsystems, i.e. object, process and product of planning, differ, dependent on the aim the model has been designed for. The planning models are characterized according to the accents made. The programs are described in figure 2 .

\subsubsection{PRECEDE-PROCEED}

\section{Gaining insight}

The most well-known health promotion planning model is Green and Kreuter's PRECEDE-PROCEED model. ' PRECEDE stands for predisposing, reinforcing, and enabling constructs in educational/environmental diagnosis and evaluation. The model starts with the question: What outcome has to be changed and which factors precede the outcome? The problems experienced by the community are the starting point. A study into these problems and its determinants is called social diagnosis. It will yield subjectively defined problems like crime, unemployment or welfare. An examination of the communities' interest will be the first step toward community participation. The acceptance of a program will be secured if an inventory is made of 


\begin{tabular}{|c|c|c|c|c|c|}
\hline & $\begin{array}{l}\text { PRECEDE.PROCEED (Green and } \\
\text { Kreuter, 1991) }\end{array}$ & $\begin{array}{l}\text { Dillution of innowations } \\
\text { 1983) }\end{array}$ & & $\begin{array}{l}\text { Community health promotion model } \\
\text { (8racht and Kingiburty, 1990) }\end{array}$ & $\begin{array}{l}\text { Intervention criapping (Bartholomev, } \\
\text { Parcel and Kok 1999) }\end{array}$ \\
\hline gsining insight & 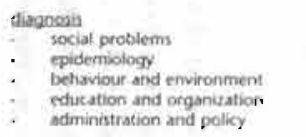 & & & $\begin{array}{l}\text { community anabso } \\
\text { define the community } \\
\text { collert dats } \\
\text { assess community capacity } \\
\text { assess commonity basmers } \\
\text { asses readiness for change }\end{array}$ & $\begin{array}{l}\text { Deech assesument } \\
\text { quality of life and heatith } \\
\text { : betuviour and ervironment } \\
\text { predictors determinants }\end{array}$ \\
\hline making decisions & 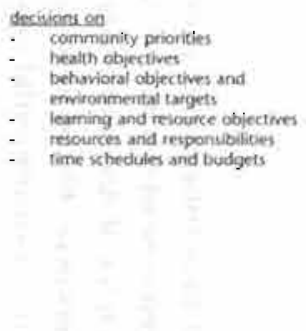 & 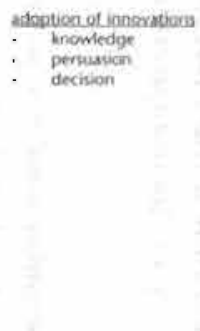 & & 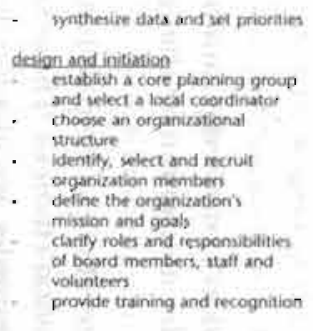 & 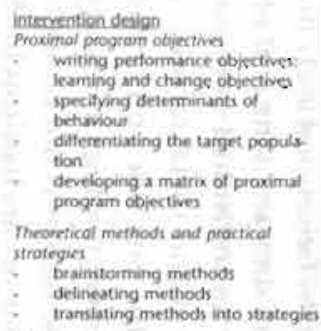 \\
\hline & & & & $=1$ & 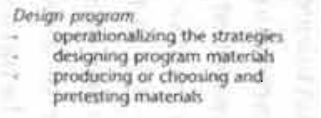 \\
\hline taking action & 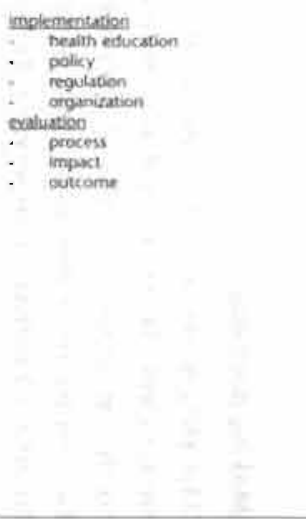 & $\begin{array}{l}\text { use of innorations } \\
\text { implementation } \\
\text { contirmation }\end{array}$ & $=$ & 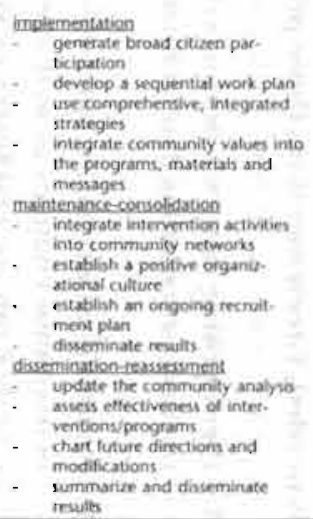 & 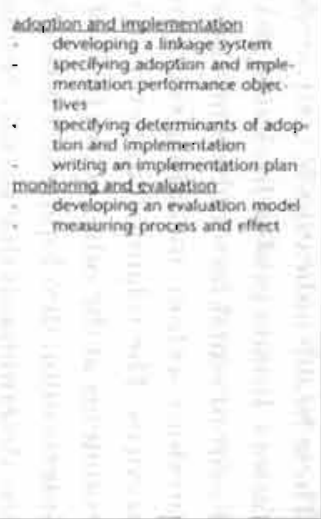 \\
\hline
\end{tabular}

$$
\text { policy }
$$

orgunization

process

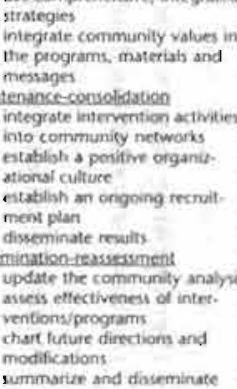


the issues that have the attention of the public. The social conditions people live in and the quality of life they experience are influenced among others by health problems. These health problems are identified using epidemiological data. Instances of indicators of the health state of a population are morbidity, discomfort or mortality. These health indicators in turn are determined by behavioral and environmental risk factors. Instances of behavioural risk factors are diet, smoking and physical exercise. Environmental factors beyond the control of an individual were mentioned in the previous section, including economic, physical and social factors, and health care services. The relationship between health at the one side and behaviours and environments at the other is the field of study of epidemiological research, however for intervention development, knowledge of these factors is not enough. Knowledge of the determinants that predict certain behaviour or mechanisms in the environment is needed. Green mentions three predictors.

1. Predisposing factors: a person's or population's knowledge, attitudes, beliefs, values and perceptions that facilitate or hinder motivation or change.

2. Enabling factors: skills, barriers or resources that can help or hinder the desired behavioural changes as well as environmental changes. These factors originate mainly from societal forces or systems. Examples are income, health insurance and law.

3. Reinforcing factors: the rewards and feedback the learner receives subsequently for his behaviour from others may encourage or discourage continuation of the behaviour.

The last diagnostic step is the assessment of organizational and administrative capabilities and resources in support of development and implementation of a program.

\section{Making decisions}

The diagnostic investigation is accompanied by a continuous process of decision making on objectives and administrative procedures, which have to be incorporated in the program. Green and Kreuter mention a lot of decision points which have to be considered when designing a program: objectives related to social problems and health, objectives concerning behavioural and environmental change, resources, administrative procedures and responsibilities (see figure 2). ${ }^{2}$ PRECEDE ends with a complete plan of priorities, targets, timetables, budgets, and assignment of responsibilities.

\section{Taking action}

PROCEED means policy, regulatory, and organizational constructs in education and environmental development. This part of the model applies to the action subsystem of planning. The barriers established in the organizational and administrative diagnosis have to be overcome when implementing the program. Much of the decision making on the organizational, regulatory and policy consequences of health promotion will continue during the action stage. PROCEED includes program evaluation. 
This actually refers to the planning subsystem gaining insight, however evaluation accompanies the execution of a program and therefore is included in the action element. The outcomes, risk factors and predictors diagnosed during PRECEDE are the criteria for program evaluation. In fact the planning follows an iterative process, as the evaluation produces insight into the process and effectiveness of a program. Decisions on the program targets and methods, target groups, dissemination strategies etcetera will be reconsidered when necessary, and the revised program will be implemented.

\subsubsection{Diffusion}

\section{Making decisions}

Diffusion is defined by Rogers as the process by which an innovation is communicated through certain channels over time among the members of a social system. ${ }^{17}$ Diffusion pertains to the decision making and action subsystems of planning. The five steps in the diffusion process are knowledge, persuasion, decision, implementation and confirmation. Knowledge and persuasion are elements of dissemination of a program. ${ }^{18}$ The innovation decision process starts with knowledge. The existence of the intervention has to be communicated to enable the program users to weigh the pros and cons of a health promotion program. They have to gain some understanding of how the intervention functions. Moreover the purpose of program dissemination is to increase the motivation of the potential users to adopt the program. Dissemination is the introductory step to activities leading to a choice to adopt or reject the innovation.

\section{Taking action}

When the users come to adopt the innovation, the process of re-invention has to be taken into account. The intervention will be changed to the users' needs and possibilities, however successful implementation depends on completeness and fidelity. ${ }^{18}$ Programs fail to be effective when only part of it is implemented. Fidelity refers to the extent to which implementers are true to the intent and methods of the program. When the implementation is successful and the interventions become institutionalized, the program users run the risk of becoming self-satisfied and losing critical self-evaluation. Continuation of a program may, in the end, contribute less to the community's health than implementing a series of new short-term health promotion programs.'

\subsubsection{Community health promotion model}

The accent of Bracht and Kingsburry's community health promotion model is on the process aspect of planning. ${ }^{19}$ The model provides a checklist of ways of how to organize communities. Community organization is defined as a planned process to activate a community to use its own structure and any available resources (internal or external) to accomplish community goals, decided in the first case by community representatives and consistent with local values. ${ }^{19}$ The outcome or product of this plan- 
ning process is community ownership: the community's acceptance of health promotion targets through their involvement in the program and their guidance of the course of the program.

\section{Gaining insight}

A profile of the community is made. The profile includes the community's needs, available resources, social structures, driving forces, like key leaders and influentials, barriers and resistances and the observed readiness for change.

\section{Making decisions}

The community members review the profile, thoroughly discuss all the information and ideas, and set priorities. An organizational structure is set up to facilitate program design and realization. A community board is formed and panels that have an advisory role are convened. An experienced and skilled coordinator is very important to program success. Program missions and goals are stated. Roles and responsibilities are clarified.

\section{Taking action}

The action planning subsystem in the community health promotion model is close to the subsystem of decision making. The conception of a work plan is recommended, covering multiple strategies concerning behavioural and environmental change. Special attention is focused on speaking the community's language, that is incorporating local values and symbols in the program. The model pays much attention to dissemination of activities and early results, and to program preservation. Dissemination is encouraged to increase the program visibility, which is critical to community participation. Recruitment of new volunteers and professionals, integration of the program in established community structures, reassessment of program goals and continuous evaluation facilitate program maintenance.

\subsubsection{Intervention mapping}

Intervention mapping was developed by Bartholomew, Parcel and Kok and provides a framework for effective decision making at each step in the intervention development process. ${ }^{20} \mathrm{It}$ builds on existing models for conducting a needs assessment and effect evaluation.

\section{Gaining insight}

The first step in planning health promotion using intervention mapping is similar to PRECEDE. The diagnosis of social, epidemiological, behavioral, environmental, educational, organizational and administrative aspects of the planning object directs the decisions on program targets and objectives, however intervention mapping makes this process more explicit and transparent. The strong side of PRECEDE-PROCEED is the insight gain into the needs of the population, the weak side is the limited attention paid to conversion of observed needs into program objectives, methods and strategies. What specific behaviour has to be changed? What are the practical pro- 
gram strategies the target population will eventually be exposed to? Is it group discussion, audio visual aids, role plays etcetera? The intervention mapping procedure pays attention to such decision making practice.

\section{Making decisions}

The behaviours and environmental outcomes desired, are stated in as much detail as possible using intervention mapping. Learning (behavioral) and change (environmental) objectives are stated in great detail, using schemes and flow charts. The preliminary list of determinants and predictors of behavioural and environmental change from the needs assessment is completed using views and theories taken from the literature. Once the target groups have been defined and program objectives restated, the practical strategies for organizing and delivering the intervention have to be developed. The decision making on practical program strategies is grounded in behavioural and social science theories. For instance role model stories are based on social learning theory, community meetings on theories about persuasive communication, and support groups on theories about social support. Methods are chosen which have proven to be effective in evaluation research. The strategies are developed in close communication with and are tested on the target group. This means that the implementation of the strategy already has started.

\section{Taking action}

A linkage system is created in which the ideas of program developers, program users (participants) and intermediate program users (implementers) meet. This system is organized preferably at the start of program, when making an assessment of the health problems together with the target group, for instance using focus groups. The needs assessment at the start of intervention mapping is extended to program implementation. Performance objectives aimed at the program implementers are delineated, for example change of their self-efficacy to introduce a program in the community and expectations regarding the program's outcome. Strategies and methods are specified in the implementation plan to facilitate the diffusion of the program among the program implementers. All stages of diffusion including evaluation and monitoring of the program have to be planned. The definition of performance objectives and determinants in the intervention mapping procedure is helpful for delineating evaluation criteria and measures.

\subsubsection{Characterization}

The health promotion planning models described above bear marks of all planning subsystems and aspect systems. Figure 3 shows where the accents of the models are placed. The accent of PRECEDE-PROCEED model is on the gaining insight subsystem. It offers a complete overview of conducting a needs assessment using diagnostic studies. Moreover, the themes or objects to be covered in the needs assessment, the outcome measures as products of the diagnosis studies and the process of conducting needs assessments are explained in PRECEDE-PROCEED. The stages of diffusion of health promotion apply primarily to the subsystems of making decisions and tak- 
ing action. Rogers' diffusing of innovations theory includes process aspects like communication processes, the role of opinion leaders and change agents. The outcomes of decision making and action is less payed attention to. The community health promotion model is a complete model with respect to the planning subsystems gaining insight, making decisions and taking action. The accent is on the process aspectsystem of planning. It describes how the community can be involved in program planning. Intervention mapping again is a complete model with respect to the planning subsystems. The focus is on the object, process and product of health promotion planning. It describes the fields of attention of health promotion, and outcomes like strategies, materials and implementation plans. Some attention is paid to the process aspect. Three core processes of intervention mapping are distinguished: the search for empirical findings from the literature, literature review of applicable theories and collecting new data from the target population, using individual or focus group interviews and questionnaires. One process should be added to this list: brainstorming techniques. The intervention mapping procedure is brim-full of making provisional lists of answers to questions one is posed. The process approaches of intervention mapping and the community health promotion model differ. The intervention mapping procedure has been criticized for the limited attention paid to involving the community in the planning process. ${ }^{21}$

- Figure 3. Characterization of health promotion planning models

\begin{tabular}{|c|c|c|c|c|}
\hline & $\begin{array}{l}\text { PRECEDE- } \\
\text { PROCEED }\end{array}$ & Diffusion & $\begin{array}{l}\text { Community } \\
\text { model }\end{array}$ & $\begin{array}{l}\text { Intervention } \\
\text { mapping }\end{array}$ \\
\hline gaining insight & $*$ & & $*$ & $x^{2}$ \\
\hline making decisions & & $\bullet$ & $\bullet$ & * \\
\hline taking action & & $*$ & $\bullet$ & s. \\
\hline object & * & & & * \\
\hline process & $\bullet$ & * & $\bullet$ & * \\
\hline product & * & & & $*$ \\
\hline
\end{tabular}

The three subsystems of planning are central in this thesis, i.e. gaining insight, making decisions and taking action, however these areas are too elaborate to cover. With respect to gaining insight the attention is focused on epidemiological diagnosis. Making decisions is dealt with when the development of health promotion interventions is described. Evaluation of the effect of actions or the execution of the health promotion program is related to the third subsystem of planning. In this thesis joined studies fall in the object and product aspectsystems, and not in the process aspectsystem of planning. 


\subsection{Epidemiological diagnosis}

\subsubsection{Descriptive and particularistic epidemiology}

Epidemiological research has been concerned with the frequency of occurrence of illness and related phenomena of health and health care. ${ }^{22}$ The occurrence relationship is studied between a health outcome and determinant. The determinant does not need to be a causal factor. ${ }^{92}$ It refers to a subject's characteristic, causal or not, that is predictive for the outcome of interest. For instance, gender can be related to a certain illness, without necessarily producing the illness. Epidemiological research is viewed as descriptive, when the studied relationship of interest is not per se causal. An example would be establishing the prevalence of loneliness among older people in relation to socio-economic status. The epidemiological diagnosis step in PRECEDEPROCEED is descriptive as its interest is in establishing the major health problems in a community, according to characteristics like age, gender, social class or geographic area. When the interest is in causal relationships, studies are designated 'analytic': what behaviours and environments cause health problems which can be altered or intervened in? ${ }^{23}$ Miettinen states that the subject of scientific epidemiology is to learn about determinant-occurrence relations in general, not limited to the time of study or place where the study is conducted. ${ }^{22}$ The object of interest of epidemiological diagnosis for health promotion is in the health or risk profile of a community. This kind of research is specific in time and place, and is referred to as particularistic research. Particularistic research often is used for administrative purposes which applies to the planning and evaluation of health promotion. The behavioral and environmental diagnosis in health promotion is most of the time descriptive and particularistic, as its concern is the prevalence of already scientifically established unhealthy lifestyles and environments in a signified population.

In descriptive epidemiology, statistics on a variety of health indicators can be assembled. Epidemiology is considered to be the intelligence service for health care. ${ }^{24}$ Information is tracked down on every step in the health promotion planning model. Health indicators gathered in epidemiological diagnosis can be summarized by the 'five D's': death (mortality), disease (morbidity), disability, discomfort and dissatisfaction.'

Some examples are given of health statistics concerning the five D's for the two populations discussed in this thesis, migrants and older adults. The standardized mortality ratio (SMR) compares the death rates of two population, standardizing for differences in age, gender or other background characteristics. For instance the, for age standardized, mortality ratios for Turkish immigrants compared to the Dutch in males is 1.19 and in females 1.25. For Moroccan immigrants compared to the Dutch the SMR are 0.77 and 1.54 respectively. ${ }^{25}$ An example of epidemiological diagnostic research into morbidity (disease) is the 6 to 10 times higher incidence of sexually transmitted diseases (STD's) among Turkish and Moroccan males for 1986 to 1989 , compared to Dutch males. ${ }^{26}$ With respect to morbidity and disability the main diag- 
noses which emerge from health care registers among males 55 years and over are hearing impairment and chronic bronchitis including emphysema, among females in the same age group arthritis and hearing impairment. Other diseases with high prevalences are diabetes, back impairment, cataract, breast cancer (among women 55-64) and coronary heart disease (among men 55-74), dementia (among 75+) and depression (among women 55-64). ${ }^{27}$ An example of discomfort or dissatisfaction is the subjective health of populations measured in surveys. For instance, the subjective health of older Surinamese, Turks and Moroccans is unfavourable compared to the older Dutch. About $70 \%$ of the older Turks, $60 \%$ of the older Moroccans, and $70 \%$ of the older Surinamese rate their health as moderate poor to very poor, compared to $35 \%$ of the Dutch $55+.^{28}$

Most public health services make a health profile with alike data for their region using national registers and conducting local surveys.

\subsubsection{Validity}

Experimental studies are the epidemiologist's golden standard. The inclusion of population members in the trial, and assignment to the experimental and control group are controlled by the researcher. The randomized controlled trial (RCT) as an example for study design in epidemiological research will be discussed in section 1.6 dealing with effect evaluation. Careful attention has to be paid to organizing the study design and threats to the validity of the research outcomes have to be considered, when conditions for controlling the design are absent. A distinction is made between external and internal validity. External validity refers to the generalizability of study results to the total population under study. Generalizability is reached when the study population is representative of the total population. Generalizability is especially important in descriptive studies which give insight into the state of health of a population. The interest of analytic studies is in causative factors. These causes are sometimes better proven in populations that, for instance, have suffered extreme exposure to a determinant as opposed to populations that have been little exposed. To uncover a causal relationship external validity is generally of secondary importance. ${ }^{29}$ The internal validity is often a more urgent problem. With respect to internal validity, three requirements can be mentioned. ${ }^{22}$

- Comparability of effects: the difference between the experimental and control group must lie exclusively in the exposition factor. The two groups have to be comparable with respect to the 'residual effect' on the health outcome under study. For instance, when the effect of a certain medicine is studied in a patient population, it is desirable to have the control group use a placebo, to exclude the effect of the mere fact that the experimental group gets a pill to cure or alleviate the disease. Comparability of effects is also a matter of excluding confounding due to extraneous factors, ${ }^{22}$ For instance, studying the effects of a certain occupation asks for comparison with occupations with similar demands and difficulties, except for the exposure factor; 
- Comparability of populations: the characteristics of the subjects from the experimental and control group have to be identical, in other words entrance into and exit from both groups have to be comparable. This is particularly critical for subject characteristics relevant to the disease. An example of differential selection of study groups is the healthy worker effect, that is the tendency for mortality rates in particular and control group. When randomization is not possible, comparability of populations is accomplished if sufficient attention is paid to the selection of the control group and controlling for differences in potential confounding characteristics in the analysis. Confounding by subject characteristics has to be considered separately from incomparability of effects as a result of confounding by extraneous factors related to the exposure. ${ }^{22}$

- Comparability of information: the experimental and control group have to be subject to the same measurement procedures. This applies to the measurement of exposure status, potential confounders and outcome status. Threats to valid ascertaining information are for instance the 'exposure suspicion bias' when a researcher knows the disease history of a patient and undertakes extra investigation to trace the risk factor, or recall bias when ascertaining the exposure status relies on patient recollection. Information bias is a problem when the researcher has more or different information about the experimental group than the control group, which leads to differential misclassification. A remedy for information bias is to 'blind' the researcher and study subjects.

\subsection{Intervention development}

The intervention mapping model was described in section 1.3. The model gives the health promotion worker tools for the development of practical strategies to bring about behavioural and environmental changes that are favourable for people's health. The object of intervention mapping is to be guided by the needs assessment made in the population of interest, including epidemiological diagnosis. The product of the intervention mapping procedure has a base in theory. One of the core processes of intervention mapping is to graze the literature, in search of theories which are applicable to the objective of changing a certain behaviour or environmental determinant and which have been tested empirically. Three theories are described in this section which were used in the interventions discussed in the empirical part of this thesis. Firstly, the ASE-model of behavioural change, secondly, peer education which is a well used method in public health services, and thirdly, the linkage approach to behavioural change or bottom up/top down strategies to organizational change.

\subsubsection{ASE-model}

Several theories have been developed in social psychology which explain behaviour. The principle theories are the health belief model, the theory of reasoned action and social learning theory. ${ }^{30-32}$ These theories are integrated in the ASE-model. ASE are the first letters of the Dutch translation of three determinants of behaviour: attitude, 
social influence and self-efficacy. ${ }^{30.45}$ These are the main determinants drawn from the social psychological theories explaining behavioural change. The ASE-model has proven to be useful in developing intervention strategies and materials in health education. The ASE-model is visualized in figure 4.

Behaviour is best predicted by the intention of an individual to perform that behaviour. ${ }^{35}$ The intention is predicted by among others, the individual's attitudes concerning the behaviour. Attitudes include beliefs about the advantages and disadvantages of a behaviour and the evaluation of these beliefs. For instance, a person's perception of negative or positive aspects of a certain behaviour influences the performance of that behaviour. These are called outcome expectations in social learning theory. The health belief model includes beliefs about benefits and barriers of behaviour to prevent a disease, and perceived threat, comprising perceived susceptibility and severity with respect to the disease. ${ }^{30}$ An example of an attitude toward using condoms (behaviour) is the belief that using condoms does not interfere in the contact with the sex partner and the positive evaluation of the use of condoms during the act. Social influences can be defined as the processes whereby people directly or indirectly influence the thoughts, feelings and actions of others. ${ }^{36}$ An example of direct social influence is the offering of a cigarette to a child by a school mate. Indirect influences from the social environment are categorized into injunctive social norms and descriptive social norms. ${ }^{37}$ Injunctive social norms are a person's subjective beliefs about the norms and expectations of individuals in the environment. Descriptive social norms are observed behaviours of others, also referred to as modelling. ${ }^{32}$ Selfefficacy is a concept from social cognitive theory and refers to people's confidence in their skills to perform a desired behaviour. ${ }^{32}$ This is called perceived behavioural control in the theory of reasoned action. ${ }^{31}$

- Figure 4. The ASE-model

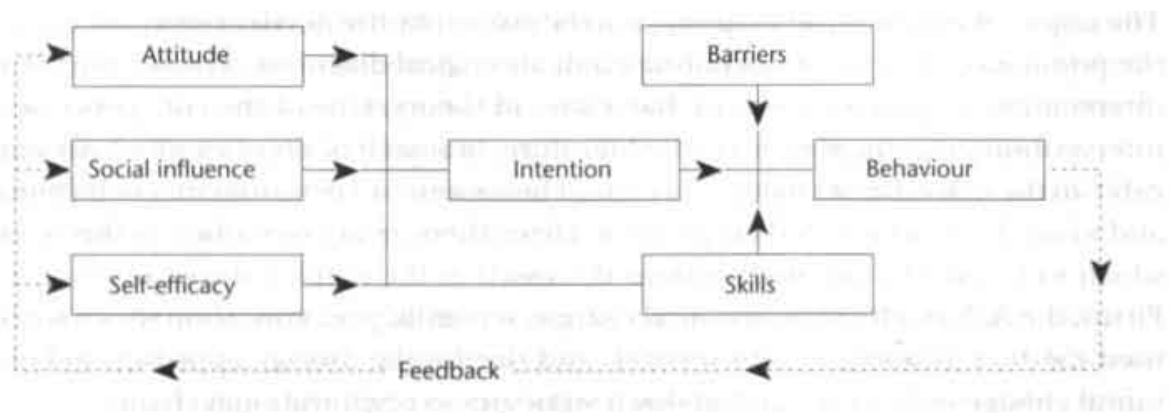

(Source: Kok G, Schaalma H, Vries H de, Parcel G, Paulussen Th. Social psychology and health education. Stroebe W, Hewstone M. European review of social psychology. Vol. 7. Chichester: Wiley \& Sons, 1996)

Attitude, self-efficacy and social influence are beliefs and evaluations directing a person's behaviour through the mental system. They have to be distinguished from the actual presence of barriers and skills. Change of people's attitude as a result of perceived barriers differs from change of the barrier itself using regulatory or organiza- 
tional measures. The same applies to people's expectation of their skills (self-efficacy) and change of the actual skills. This distinction is compatible to the classification of predisposing factors that have to be distinguished from reinforcing and enabling factors. ${ }^{1,35}$ Feedback refers to experiences with behaviour which in turn change the social psychological determinants of behaviour. ${ }^{33}$ (see figure 4 ).

\subsubsection{Peer education}

The efficacy of the peer education method can be understood well in view of the principles of social learning theory. Social learning theory is considered to be a complete theory as it addresses both determinants of behaviour change and methods of promoting change. ${ }^{38}$ Peer education is education delivered by people from the target group. Examples of peers, or lay health advisors or community health advisors as they are sometimes indicated, are adolescents educating their school mates in a smoking cessation program, elderly educating people of the same age in a physical exercise program, or prostitutes educating their colleagues in a safer sex program. Peer educators are trained to deliver the health promotion message. They use verbal persuasion techniques, however additional, indirect methods sustain the communication. The interaction between individuals and their environment is central in social learning theory, explaining the change in people's belief in their competencies (self-efficacy) to improve their health. The peer educator is put into action as a role model. Modelling is the principle of forming rules of behaviour through observing others, and on future occasions this coded information serves as a guide for action. ${ }^{32}$ Modelling does not mean imitation of behaviour. The observed behaviours are converted to suit different purposes and circumstances. Modelling affects personal skills and behaviours, inhibitions over behaviour, behaviours not yet cued, creativity to show new behaviour and emotional reactions to modelled behaviour. ${ }^{32}$ Behavioural change is induced by the change of determinants of behaviour. Seeing or visualizing other similar people (peers) perform successfully (vicarious experience) can improve or strengthen the perception of self-efficacy to perform comparable activities. The positive evaluation of the outcome of a behaviour demonstrated by the peer will have an effect on the attitude towards the behaviour. In social learning theory a person's estimate that a certain behaviour will lead to certain outcomes is called outcome expectation. Modelling is comparable to the influence of descriptive social norms. Moreover, a peer can address a person's perception of social norms (injunctive social norms), however, social support from a person's immediate social network will have a larger impact on behaviour than the temporary presence of a peer. ${ }^{39}$ For instance, the adoption of safe sex practice in the gay community was brought about in the long term, after starting with peer projects. The more friends used and regarded condoms positively, the more gay men believed in their efficacy to overcome interpersonal barriers to safer sex practices.

Similarity between observer and model (peer) is related to comparative past experiences and personal characteristics and attributes like age, gender, ethnic designation and socio-economic level. ${ }^{32}$ Similarity generally increases the impact of modelling, 
even when these characteristics are not predictive for performance capabilities. In diffusion theory, evidence is given of the positive influence of similarity between observer and peer on adoption of behaviour. ${ }^{17}$ Peers are thought to have less competence credibility or expertness than a professional, but they have the advantage of safety credibility or trustworthiness. The intentions of a peer are experienced by the observer to be safe and not manipulative.

Several studies have reported on the lack of empirical evidence of the mechanisms that explain the influence of peer education on behaviour. ${ }^{40-3}$ Further research into the effects of peer education, e.g. compared to expert-led health education, is recommended. ${ }^{4+}$

\subsubsection{The linkage approach}

A gap often exists between the development of an intervention and its diffusion. ${ }^{45} \mathrm{~A}$ proposed resolution to bridge this gap is to have the program users be involved in program development at an early stage, using a linkage system. A linkage system is defined as the cooperative exchanges and interactions required collaboratively to develop user-relevant innovations and diffusion strategies. ${ }^{45}$ The linkage system connects the resource system (program designers), user systems (program users and intermediate program users) and change agents. The latter facilitate the collaboration process. The needs assessment process described in the PRECEDE-PROCEEDmodel ensures an early commitment of the program users, when a social diagnosis of the health problem is made. Methods to pursue program ownership in the community are for instance local work groups, community hearings and discussions and training of key figures from the community. ${ }^{19,1}$

The concept of linkage systems corresponds to the mechanism of horizontal networks among the program users, introduced in the innovation theory. ${ }^{17}$ The question is who is central in the diffusion of an innovation. The classical diffusion model describes a centralized diffusion system in which decisions about commencing an innovation, its evaluation and the channels through which it will be communicated are made central in an organization by a small number of management executives. In practice an innovation often originates from numerous resources and evolves as it diffuses via horizontal networks. This decentralized diffusion system is thought to warrant the adoption of an innovation best, because the users share in the decision making, however the required technical expertise must not be too high. Re-invention is the key word in this bottom up process. Users should have the opportunity to modify an intervention to fit their needs and capacities. The innovation will have more prospect of being adopted, if the users have the feeling they have invented the structure, idea or practice themselves.

The problem of involvement of program users can be viewed as a general administrative or managerial problem. Who is governing or guiding whom? Decision making by a hierarchical unit at the top is called top down management. Allowing ideas to be 
generated at the lower units of an organization, within the limits of the organizational structure is called bottom up management. ${ }^{3}$ Use of linkage systems corresponds to the bottom up or democratic approach towards program planning. An innovation can be defined in managerial terms as the development and implementation of new ideas by people who, over time, engage in transaction with each other within an institutional order. ${ }^{46}$ This definition emphasizes the joint action of different people or multiple organization units. This totality of interacting units can be viewed as an interorganizational network. An important characteristic is the exchange of resources among the members of the network, all acting out of different interests and authority. ${ }^{47}$ The management of this network of program users, intermediate users, designers and change agents is a task of dreadful complexity. ${ }^{46}$ The solution that is proposed goes beyond the top down bottom up controversy. The innovation process is not viewed as a sequence of separable stages that goes from customer to marketing department to $R \& D$ department, or the other way round. The interorganizational network consists of self organizing units, which have a good knowledge of their function in relation to other units' speciality and understand the direction of the overall innovation (think globally while acting locally). An institutional, supportive leadership is needed to transform a set of innovative ideas into a set of guiding ideals. The institutional, charismatic leadership, accompanied by mission statements, use of personal networks, rituals and symbols, has to be distinguished from technical or instrumental leadership. ${ }^{46}$

\subsection{Effect evaluation}

\subsubsection{Evaluation methods}

Diagnosing the health problem and intervention mapping result in performance objectives which are criteria for assessment of the health promotion program's success or failure. An evaluation study can serve different official and unofficial purposes. ${ }^{48}$ Examples of unofficial, hidden purposes are public relations, legitimization, budget cuts and change inducement. Overt, official purposes are, for instance, gaining insight into the working of a program, judgement, program development or improvement of program effectiveness. A distinction can be made between formative and summative evaluation. Summative evaluation works up to a final judgement of the effectiveness of a program. The question should be answered whether the program works, to make a decision on the continuation or broader implementation of a program possible. Formative evaluation gives answers to the question of how the program works. It is aimed at exploration of program improvement and facilitates discussion on the progress of a program. ${ }^{48}$ Different methods can be used in the formative and summative evaluation of programs, among others monitoring, continuous internal evaluation and experimental methods.

Another dividing principle in evaluation research is the evaluation of process and effect. Effect evaluation demonstrates whether the program is successful, process evaluation gives an understanding of why it was successful. It is not always clear whether an indicator measures the process or the effect of a program. For instance, a cardi- 
ologist will judge smoking cessation to be a process indicator for the outcome of prevention of cardiovascular disease. A health educator will call smoking cessation an effect indicator and prevention of cardiovascular disease an effect in the long term. ${ }^{49}$ Process evaluation in health promotion addresses indicators like exposure to the intervention, reach of the target population, completeness of implementation of the intended intervention, fidelity among intermediate program users to the program aims and intentions, and satisfaction of program users. ${ }^{18,50}$ The distinction between process and effect evaluation does not necessarily follow the classification of formative and summative evaluation. An effect evaluation can be formative, depending on the criteria that are used to guide the assessment of a program's success. For instance, the assessment of the effect of a program component can be an intermediate step in the formative evaluation, and may motivate the adaptation of the program course. The above mentioned types of evaluation do not match the distinction made between qualitative and quantitative evaluation methods. For instance, a monitoring system generates routine data on the progress of a program, like data on the number of program users, evaluative assessments of visitors, themes of health education sessions etcetera. These quantitative data can be used as a formative, process instrument.

Experimental evaluation methods will be discussed in the remainder of this section. The use of a control group is an important characteristic of experimental evaluation designs. The experimental group which is exposed to the intervention under study is compared to a control group that does not undergo the intervention. Experimental designs are generally used as summative and quantitative effect evaluation methods. The effect evaluation studies included in this thesis meet the characteristics of experimental designs.

The Randomized Controlled Trial (RCT) is viewed in epidemiology as the evaluation method which produces the most valid results in intervention studies. The formula given in figure 5 makes clear which factors determine the observed effect of an intervention. The intervention effect is the effect of interest. The experimental and control group have to be comparable with respect to the natural course of the disease under study, external effects and information bias. The difference in observed effect between the experimental and control group in this case equals the intervention effect. Remedies have been mentioned in section 1.4 which ensure the comparability of natural course (comparability of populations), external effects (comparability of effects) and information bias (comparability of information). The remedies are randomization of the study population to the experimental and control group, a placebo intervention in the control group and blinding of researcher and study subjects. These conditions can often only be realized in a laboratory. Health promotion programs take place in real life settings that only allow for limited control in evaluation research. Quasi-experimental designs are used in the social sciences to deal with the problems of doing research into the daily life of human beings. ${ }^{51.52}$ An example is the nonequivalent control group design. This design does not guarantee comparable experimental and control groups, however it is regarded a next best design if randomization is not possible. The experimental and untreated control group receive 
a pre-test and post-test The pre-test delivers data on the comparability of the study groups. Differences with respect to potential confounders can be controlled for in the analysis.

- Figure 5. Epidemiological formula

$\begin{array}{ll}\text { O } & \text { observed effect } \\ = & \\ + & \text { intervention effect } \\ + & \\ \text { NC } & \text { natural course } \\ + & \\ \text { EE } & \text { external effects } \\ + & \\ \text { IB } & \text { information bias }\end{array}$

\subsubsection{Methods used in the real life setting of a public health service}

The powerful solution of the RCT for validity threats is valuable for the evaluation of health promotion programs. The real life setting of a public health service does not release the researcher from seeking solutions that approach the RCT design. Creativity is required if circumstances do not allow for randomized assignment to an experimental and control group. Health promotion is often aimed at populations and not at individuals. Randomization of populations as an alternative, is often used in group health education, e.g. randomization of school classes. Another alternative for the RCT is a Community Intervention Trial (CIT).$^{53}$ The intervention is assigned to experimental and control communities at random. A CIT encounters other problems that have to be overcome, i.e. program targets and target groups have to originate within the community and therefore base line measurement at the start of a community program is difficult, the duration of the trial is often too short to establish effects, and both experimental and control communities change due to mass media campaigns. Often the populations cannot be segregated adequately which has the consequence that in the longer run the community intervention is disseminated in the control group. Moreover, with an experimental design the researcher is often not able to measure all the effects and side effects of a complex community health pro$\operatorname{gram}^{50}$

Another drawback of the use of RCTs in health promotion is that they are designed to prove an intervention effect, separated from interfering circumstances (explanatory approach), however these laboratory conditions seldom happen in daily life. The aim of RCTs is to prove the efficacy opposed to the effectiveness in normal conditions. ${ }^{24}$ In the pragmatic approach daily circumstances are part of the intervention and inclusion of a placebo is not necessary. ${ }^{54}$ For instance, the mere effect of the attention a person receives when visiting a health education session is accepted in a pragmatic trial. Assessment of overall effectiveness, regardless of knowledge of what part of the intervention really explains the effect, is acceptable for health promotion, because in daily life the placebo is part of the intervention. 
A last difficulty that adheres to the application of RCTs in public health practice is the possibility of loss to follow-up after randomization, if study subjects are not assigned to the intervention of their choice. Study subjects have to be informed extensively about the pros and cons of the treatment alternatives. In the traditional RCT informed consent is asked for from study subjects before assignment to the experimental and control group. Pre-randomization of eligible study subjects prior to the informed consent procedure is proposed in the Zelen design ${ }^{535}$ Informed consent then only has to be acquired for the intervention the study subject has been assigned to. The loss to follow up among control subjects is expected to be less, because they will be unaware of the alternative choice. The Zelen design especially is applicable to situations where the treatment under study is very attractive. The applicability of the Zelen design to the evaluation of a normal educational program is limited, because practice teaches us that only a small section of the population will participate in an educational course. In the Zelen design refusing subjects have to be included in the analysis procedure (intention to treat) and as a consequence effectiveness will be difficult to establish if participation in the education course among the experimental group is poor. The Zelen design has been criticized as unethical, as the subject does not have full knowledge of the study he or she has been asked to participate in.

Use of multiple evaluation methods is recommended to meet the problems met when applying the randomization, placebo and blinding principles of RCT in the real life setting of a public health service. ${ }^{53.58}$ The use of multiple data sources in a combination of the above mentioned types of evaluation methods, formative and summative, process and effect evaluation, qualitative and quantitative methods, will provide an optimal answer to the research questions at issue. Conclusions can be drawn if the results of these combined evaluation studies point in the same direction (triangulation).

The use of a RCT design is dependent on the purpose of the evaluation. A solid evaluation is recommended if a health promotion program is innovative, costly, controversial or risky. Monitoring systems or other methods are useful if the effectiveness of a method has already been demonstrated, or the program is not far-reaching. ${ }^{53}$ The choice of an evaluation method often is dependent on information about program means and ends at the time of program implementation. Evaluation methods that are summative in nature and assess the effectiveness of programs are usable in situations where clarity and agreement exists about program aims. Program outlines are less clear if the program develops over time and the program planners act out of different objectives, interests and problem perceptions. Formative and process evaluation methods are more obvious in a social-interaction model defining policy making as the result or even side-effect of negotiations, conflicts, coalitions and persuasion among actors. ${ }^{15.48}$ 


\subsection{Programs' histories}

The empirical studies presented in this thesis are outlined briefly in this section. Programs under the administration of the Rotterdam area Municipal Health Service (RMHS) were studied. The studies are described in chronological order to demonstrate the development of the programs.

\subsubsection{Older adults}

\section{Psycho-social problems in older adults: diagnosis}

An epidemiological diagnosis was carried out into the psycho-social problems of the Rotterdam elderly population. This research project was conducted in 1989 to support the planning of health promotion programs aimed at older adults. The Rotterdam area Municipal Health Service had privatised the department of mental health and set up a new department which was asked to prepare a public mental health policy for the city government. This department commissioned to the RMHS department of epidemiology to carry out several research projects. The epidemiological diagnosis was designed to yield proposals to prevent psychological problems in older adults. A cross-sectional survey was conducted among independent living older adults of 65 to 79 years of age. A sample received a postal questionnaire and part of it was interviewed, using a psychiatric interview schedule.

\section{Prevention of loneliness: intervention development}

The results of the epidemiological diagnosis gave rise to an intervention designed to prevent loneliness in older adults. The loneliness intervention program 'In Good Company' was started together with a Regional Institute of Ambulatory Mental Health Care in the western area of Rotterdam in 1991. Other city organizations were invited to participate in the program. Experiments were conducted in three Rotterdam neighbourhoods in the period up to 1995. The planning of the program and satisfaction with the program among intermediate program users was evaluated. The program was coordinated by the RMHS department of public mental health and the evaluation was conducted by the RMHS department of epidemiology. In the meantime parts of the Rotterdam departments of public mental health and epidemiology were brought together to form a new department of epidemiology and health policy.

\section{Peer-led senior health education: effect evaluation}

The RMHS department of health promotion received many requests from elderly organizations to arrange health education for their clients. The department had positive experiences with peer education for migrant inhabitants of Rotterdam. It was expected that peer education would also be successful in the population of older adults. A group of older adults were trained as peer health educators, called senior health educators, in 1994. A scientific committee funding research projects into determinants of health on behalf of central government, asked the RMHS to evaluate the senior health education program. The effectiveness of the program was evaluated by the department of health promotion in cooperation with the department of 
epidemiology and health policy in the period 1995 to 1997. These departments were then integrated in a new department of health promotion, comprising the three disciplines epidemiology, health promotion and health policy, in 1997.

\subsubsection{Migrants}

\section{The health of the Rotterdam Surinamese: diagnosis}

The RMHS department of epidemiology had developed several register systems and recurrent surveys to monitor the health of the Rotterdam inhabitants. The health of the major immigrant groups, Turkish and Moroccan, had been analyzed using these data systems, however little was known of the health of another important immigrant group, the Surinamese. A secondary analysis of survey and mortality data was conducted in 1993 to give insight into the mortality, subjective health and reported health care use of the Rotterdam Surinamese.

\section{Peer-led AIDS education in male Turkish and Moroccan immigrants: effect evaluation}

The RMHS had quite some experience with peer education in immigrant groups. AIDS education for immigrants was one of the peer projects. It originated in 1989 when the AIDS epidemic was at its height and the Dutch mass-media campaigns had some difficulties in reaching immigrant groups. The RMHS coordinated the peerled AIDS education for immigrants at national level, however an evaluation of the effectiveness of the program was lacking. In 1996 the scientific committee of the national AIDS fund provided a grant to start an effect evaluation of the AIDS education in Turkish and Moroccan men.

\section{Peer-led AIDS education in male Turkish and Moroccan immigrants: intervention develop- ment}

There had been several years of peer-led AIDS education at the time the evaluation study started. A qualitative study was carried out among the peer educators into the targets of the AIDS education, using group interview techniques. Scales were developed in cooperation with the peer educators to measure the effectiveness of the AIDS education among the Turkish and Moroccan frequenters of coffee houses and mosques. The data of the pre-test were used to study determinants of condom use. The study into the program targets and determinants of behaviour yielded recommendations for the future development of the peer-led AIDS education program aimed at immigrants.

The studies depicted above are presented in the following chapters. They have been arranged per target group, starting with the programs aimed at migrants in chapters 2 to 4 . The studies of the programs aimed at older adults are described in chapters 5 to 9 . The conclusions and discussion regarding the in section 1.1 introduced main research question are given in chapter 10.

new ' The author wishes to thank Willy de Haes and Hans Saan for a discussion on this topic. 


\section{References}

1. Green LW, Kreuter MW. Health promotion planning: an educational and environmental approach. 2nd ed. Mountain View: Mayfield, 1991.

2. Vught FA van. Experimentele beleidsplanning: bestuurskundige expidities in de jungle van het planningsdenken. 's-Gravenhage: VUGA, 1982.

3. Leeuw $\mathrm{ACJ}$ de, Organisaties, management, analyse, ontwerp en verandering; een systeemvisie. Assen: Van Gorcum, 1982.

4. Rade N. Smit J de. Planning, besturing en organisatie van planning. Processen van kennisvorming, wilsvorming en machtsvorming in relatie tot planning, besturing en politiek. Gevers JKM, Veld $\mathrm{RJ}$ in ' $\mathrm{t}$ (red.). Planning als maatschappelijke vormgeving, Mens en Maatschappij, boekaflevering. Deventer: Van Loghum Slaterus, 1980.

5. Green LW, Kreuter MW, Deeds SG, Partridge KB. Health education planning; a diagnostic approach. Palo Alto: Mayfield, 1980.

6. Haes, WFM de. Gedragswetenschappelijk onderzoek ten dienste van gezondheidsvoorlichting en -opvoeding (GVO). Lisse: Swets \& Zeitlinger, 1983.

7. Nutbeam D. Health promotion glossary. Health Promotion International 1998:13:349-364.

8. Essink-Bot ML, Haes JCJM de. Kwaliteit van leven in medisch onderzoek. Amsterdam University Press, 1996.

9. LaLonde MA. A new perspective on the health of the Canadians. Ottawa: Ministry of National Health and Welfare, 1974.

10. Milio N. Promoting health through public policy. Ottawa: Canadian Public Health Association, 1986.

11. Nutbeam D. Health outcomes and health promotion. Defining success in health promotion. Health Promotion Journal of Australia 1996;6(2):58-60.

12. Leeuw $\mathrm{E}$ de. Health policy: an exploratory inquiry in the development of policy for new public health in the Netherlands. Thesis Rijksuniversiteit Limburg. Maastricht, 1989.

13. Green L. Community health. St. Louis: Times Mirror/Mosby College Publishing, 1990.

14. Dror $\mathrm{Y}$. The planning process: a facet design. Faludi A. A reader in planning theory. Oxford: Pergamon, 1973.

15. Grünwald CA, Meer D van der. De beheersing van de collectieve sector als beleidsvraagstuk: de bijdrage van de wetenschap. Bestuurswetenschappen 1984;39:416-432.

16. Vries $\mathrm{H}$ de, Kok G. Gezondheidsbevordering: een toepassing van het $\mathrm{ABC}$-planningsmodel. Health promotion: an application of the ABC-planning model. Gedrag \& Gezondheid 1996;24:342-352.

17. Rogers EM. Diffusion of innovations. 3d ed. New York: Free Press, 1983.

18. Parcel GS, Perry CL. Taylor WC. Beyond demonstration; diffusion of health promotion innovations. Bracht N (ed). Health promotion at the community level. Newburry Park: Sage, 1990.

19. Bracht N, Kingsburry L. Community organization principles in health promotion: a five-stage model. Bracht N (ed). Health promotion at the community level. Newburry Park: Sage, 1990.

20. Bartholomew LK, Parcel G, Kok G. Intervention mapping: a process for developing theory- and evidence-based health education programs. Health Education \& Behavior 1998:25:245-563.

21. Heaney CA. Intervention mapping and the new health promotion. Health Educ \& Behavior $1998 ; 25: 564-568$. 
22. Miettinen OS. Theoretical epidemiology. Principles of occurrence research in medicine, New York: Wiley, 1985.

23. Kelsey JL., Thompson WD, Evans AS. Methods in observational epidemiology. New York: Oxford University Press, 1986.

24. Sturmans F. Epidemiologie; theorie, methoden en toepassing. Nijmegen: Dekker \& van de Vegt, 1982.

25. Wersch SFM, Uniken Venema HP, Schulpen TWJ. De gezondheidstoestand van allochtonen. Mackenbach JP, Verkleij H. Volksgezondheids Toekomst Verkenning 1997 II: Gezondheidsverschillen. Maarssen: Elsevier/de Tijdstroom. Bilthoven: RIVM, 1997, 199-223.

26. Laar MJW van de, Sleutjes MPM, Postema CA, Water HPA van de. Seksueel overdraagbare aandoeningen bij allochtone bevolkingsgroepen; een oriènterend onderzoek. Ned Tijjschr Geneesk 1991;135:1542-1547.

27. Pot AM, Deeg DJH. De gezondheidstoestand van ouderen. Mackenbach JP, Verkleij H. Volksgezondheids Toekomst Verkenning 1997 II: Gezondheidsverschillen. Maarssen: Elsevier/ de Tijdstroom. Bilthoven: RIVM, 1997, 105-132.

28. Tesser PTM, Dugteren FA van, Mertens JGF. Rapportage minderenheden 1998. De eerste generatie in de derde levensfase. Rijswijk: Sociaal Cultureel Planbureau, Den Haag: Elsevier, 1998.

29. Bouter LM, Dongen MCJM van. Epidemiologisch onderzoek; opzet en interpretatie. Utrecht: Bohn, Scheltema en Holkema, 1988.

30. Janz NK, Becker MH. The health belief model; a decade later. Health Education Quarterly 1984:11:1-47.

31. Ajzen 1. The theory of planned behaviour. Organizational behaviour and human decision processes 1991:50:179-211.

32. Bandura A. Social foundations of thought and action; a social cognitive theory. Englewood Cliffs N]: Prentice Hall, 1986.

33. Kok G, Schaalma H, Vries H de, Parcel G. Paulussen Th. Social psychology and health education. Stroebe W, Hewstone M. European review of social psychology. Volume 7. Chichester:Wiley \& Sons, 1996.

34. De Vries $\mathrm{H}$, Mudde A. Predicting stage transitions for smoking cessation applying the Attitude Social influence - Efficacy Model. Psychology \& Health 1998;13:369-385.

35. Fishbein M, Ajzen 1. Belief, attitude, intention and behaviour; an introduction to theory and research. Reading, MA: Addison Wesley, 1975.

36. Vries $\mathrm{H}$ de, Backbier E. Kok G. Dijkstra M. The impact of social influences in the context of attitude, self-efficacy, intention and previous behaviours as predictors of smoking onset. J Appl Soc Psychol 1995:25:237-257.

37. Cialdini RB, Reno RR, Kallgren CA. A focus theory of normative conduct; recycling the concept of norms to reduce littering in public places.J of Personality and Social Psychol 1990;58:10151026.

38. Nutbeam D. Harris E. Theory in a nutshell: a practitioner's guide to commonly used theories and models in health promotion. Sydney: National Centre for Health Promotion, 1998.

39. Bandura A. Social cognitive theory and exercise of control over HIV infection. DiClemente RJ. Peterson JL (ed). Preventing AIDS; theories and methods of behavioral interventions. New York: Plenum Press, 1994.

40. Turner G, Shepherd J. A method in search of a theory: peer education and health promotion. Health Educ Res 1999:14:235-247. 
41. Frankham J. Peer education: the unauthorised version. Br Educ Res J 1998:24:179-193.

42. Milburn K. A critical review of peer education with young people with special reference to sexual health. Health Educ Res 1995;10:407-420.

43. Rijke B, Vries $\mathrm{N}$ de. Peers doen het beter...! Peer-voorlichting bij jongeren. Tijdschr Gezondheidsbevordering 1995;16:103-116.

44. Klepp KI, Halper A, Perry CL. The efficacy of peer leaders in drug abuse prevention. Journal of School Health 1986;56:407-411.

45. Orlandi M, Landers C, Weston R, Haley N. Diffusion of health promotion innovations, Glanz K, Marcus Lewis F, Rimer BK (ed). Health behavior and health education. San Fransisco: Jossey Bass, 1990.

46. Ven, AH van de. Central problems in the management of innovations. Management Science 1986:32:590-607.

47. Benson JK. The interorganizational network as a political economy. Administrative Science Quarterly 1975:20:229-249.

48. Donker, M. Principes en praktijk van programma-evaluatie; opzet en rendement in de geestelijke gezondheidszorg. Dissertatie. Utrecht: NcGv, 1990.

49. Kok G. Proces- en effectevaluatie van GVO-interventies. TSG 1998:76:284-285.

50. Nutbeam D. Evaluating health promotion: progress, problems and solutions. Health Promotion International 1998:13:27-44.

51. Cook TD, Campbell DT. Quasi-experimentation; design \& analysis issues for field settings. Boston: Houghton Mifflin, 1979.

52. Popham WJ. Educational evaluation. Englewood Cliffs N]: Prentice-Hall, 1975.

53. Nutbeam D. Evaluatie van oorzaak en gevolg in gezondheidbevorderingsprojecten; aanpassing van onderzoeksmethoden aan interventiemethoden. TSG 1999;77:15-23.

54. Schwartz D, Lellouch J. Explanatory and pragmatic attitudes in therapeutical trials. J Chron Dis $1967 ; 20: 637-648$.

55. Zelen M. A new design for randomized clinical trials. New England J of Medicine 1979:300:12421245.

56. Schellings R, Kessels AGH, Geurs R, Sturmans F. Een herwaardering van het Zelen-design: de bruikbaarheid bij een gerandomiseerd heroine verstrekkingsexperiment. T Alc Drugs 1995;21:6778.

57. Sturmans F. Evaluatieonderzoek in extramurale omstandigheden. TSG 1999:77:29-32.

58. Tones K. De evaluatie van gezondheidsbevordering; een verhaal van drie fouten. TSG 1999:77:2428. 
Migrants 


\section{Chapter 2}

Mortality, self-rated health and reported use of health care among

the Rotterdam Surinamese

epidemiological diagnosis

intervention development

effect evaluation 


\section{Abstract}

The differences in mortality, self-rated health and reported use of health care services between Surinam and Dutch citizens of Rotterdam were investigated. Mortality data from the registrar's office were analyzed. It was concluded that mortality is higher in male Surinamese aged 15 to 34 and female Surinamese aged 55 to 74 . Health status and health care use were analyzed using postal questionnaires sent to random samples of Rotterdam inhabitants (aged between 16 and 75). Logistic regression analysis was used, in which gender, age, marital status, level of education and work situation were taken into account. The results showed that a higher proportion of Surinamese than Dutch respondents considered their health to be poor. Moreover more Surinamese than Dutch people had had contact with their general practitioner one or more times during the last two months. Further research into the health situation and causes of death in the Surinamese is recommended. 


\section{Mortality, self-rated health and reported use of health care among the Rotterdam Surinamese}

\subsection{Introduction}

Considerable numbers of Surinamese have emigrated to the Netherlands over the years. Their motives are better education prospects and the desire to fulfil ambitions.' People from all social classes have taken their chance to emigrate. A total of 39,838 Surinamese lived in Rotterdam in 1991, which amounted to $7 \%$ of the Rotterdam general population and $15 \%$ of the Surinam population in the Netherlands. About $45 \%$ of the Surinamese in the Netherlands is Hindu and $45 \%$ is Creole. ${ }^{2}$ Other Surinamese ethnic groups are formed by, among others, Indians, Javanese and Chinese. Little research has been conducted into the health of the Surinamese living in the Netherlands. The Surinamese rate their health as poorer than the Dutch., 3,6 Moreover, they visit their general practitioner more frequently. ${ }^{3,7}$ The higher mortality among the Surinamese, compared to the Dutch is an indication for a poorer health situation. ${ }^{8}$ These findings are based on limited study populations and most studies do not take into account a difference in socio-economic status between the Surinamese and the Dutch. ${ }^{58}$ Evidence exists of the relationship between socio-economic inequalities and health. ${ }^{4}$ The Surinamese suffer from less income, more unemployment, less education and deprived housing circumstances, when compared to the Dutch. ${ }^{13}$ The causes of the inequality in health, whether socio-economic or ethnic, have not yet been unravelled.

The policy of improving health in socio-economic deprived populations and the limited knowledge of the health situation of the Surinamese, gave reason to conduct this study. ${ }^{9}$ The Rotterdam Surinamese population is expected to increase by $46 \%$ from 1991 to 2006. The following research questions are addressed. Are there differences in mortality, subjective health and reported health care use between the Surinam and autochthonous citizens of Rotterdam? Can a difference in subjective health and reported health care use be explained by the educational level and work situation of the respondents? The association between mortality and socio-economic status was not studied, because socio-economic data are not given in the registers used.

\subsection{Materials and methods}

\subsubsection{Analysis of mortality data}

Mortality data were provided from the registrar's office of the city of Rotterdam. The index-population consisted of Rotterdam Surinamese who were of Dutch nationality, and who themselves or whose father or mother were born in Surinam. Inhabitants of Surinam nationality were excluded to allow comparison with the study population of the survey (see hereafter). About $91 \%$ of the Rotterdam Surinamese had Dutch nationality in 1991. A comparison was made with the standard population including both the index population and all other city inhabitants of Dutch nationality. Only 
mortality after the age of 1 year will be considered in this article for technical reasons. Data were only available on mortality for residents of Rotterdam on the first of January of the year they deceased. As a result of this, statistics on perinatal and infant mortality were missed.

Mortality rates were standardized indirectly for men and women separately accounting for age, using Standardized Mortality Ratios (SMRs). ${ }^{10,11}$ The mortality figures from 1986 to 1991 were added up to obtain populations of sufficient magnitude, and ten years age categories were used. The number of Surinamese with Dutch nationality who died during the six years follow up period was 525 ( 280 males, 245 females). Significance was tested using $95 \%$ confidence intervals (95\%-CIs). ${ }^{12}$

\subsubsection{Analysis of survey data}

A secondary analysis was conducted of data from the Omnibus survey. Postal questionnaires were sent yearly from 1987 to 1991 to different samples drawn at random from the Rotterdam registrar's office. ${ }^{13-15}$ These samples comprised Rotterdam inhabitants of Dutch nationality aged 16 to 75 years, including citizens born in Surinam or whose father or mother had been born in Surinam. The index population of Surinamese amounted to 471 people. The reference population was a sample drawn from the respondents to the Omnibus questionnaires, a total of 2826 respondents who had themselves and whose father and mother had been born in the Netherlands.

The response rates to the questionnaires were about $60 \%$. An assessment of the response rates among the Surinam population was not possible, because of unknown denominators (size of samples from Surinam inhabitants), however response to the questionnaires among the Surinamese was lower than expected from census data. In $19916.2 \%$ of the Rotterdam population aged 16-75 with Dutch nationality was of Surinamese origin, compared to $4.2 \%$ of the survey respondents. The index-population was representative for the Rotterdam Surinamese of Dutch nationality in 1991, considering gender, age and marital status. In the response group of Dutch origin, married people were overrepresented, $57.6 \%$ of the respondents were married compared to $48.8 \%$ in the general population.

The associations between country of origin and the following outcome measures were established:

1. self-rated health: the respondents evaluated their health as good, moderate poor or poor:

2. psycho-social health: wellbeing was assessed using the subscale negative affect of the Affect Balance Scale (ABS). ${ }^{16,17}$ The cut-off point was 4 on a scale from 0 to 12 ;

3. contact with the general practitioner (GP): contact with the GP during the last two months was assessed, including the frequency of contacts; 
4. use of Regional Institutes of Ambulatory Mental Health Care (RIAMHCs); contact with the RIAMHC during the last five years.

Response to the outcome measures differed dependent on in which years the scales and questions were included in the questionnaires.

The following background characteristics were asked in the questionnaires: gender, age, marital status, educational level as an indicator for socio-economic level, and work situation. Work situation comprised the following categories: paid job, unemployment benefit, invalidity pension, social security, student, retired, or running the house. The index and reference populations differed significantly with respect to the background characteristics, except for gender (table 1). Research has shown an association between these characteristics and the outcome measures. ${ }^{13-15}$ The confounding effects and effect modification were studied, using multiple logistic regression analysis. ${ }^{18}$ Odds Ratios (ORs) were tested, using 95\%-confidence intervals (95\%-CIs).

- Table 1. The background characteristics of the Surinam and Dutch respondents

\begin{tabular}{|c|c|c|c|c|c|}
\hline & & \multicolumn{2}{|c|}{ Surinamese } & \multicolumn{2}{|c|}{ Dutch } \\
\hline & & $n$ & $\%$ & $n$ & $\%$ \\
\hline \multirow[t]{2}{*}{ gender } & male & 207 & 44.4 & 1324 & 47.1 \\
\hline & female & 259 & 55.6 & 1490 & 52.9 \\
\hline \multirow[t]{6}{*}{ age* } & $16-24$ & 140 & 29.7 & 465 & 16.5 \\
\hline & $25-34$ & 132 & 28.0 & 574 & 20.3 \\
\hline & 35.44 & 96 & 20.4 & 508 & 18.0 \\
\hline & $45-54$ & 54 & 11.5 & 403 & 14.3 \\
\hline & 55.64 & 38 & 8.1 & 472 & 16.7 \\
\hline & $65-75$ & 11 & 2.3 & 404 & 14.3 \\
\hline \multirow[t]{4}{*}{ marital status" } & unmarried & 217 & 46.3 & 869 & 30.8 \\
\hline & divorced & 81 & 17.3 & 184 & 6.5 \\
\hline & widowed & 11 & 2.3 & 144 & 5.1 \\
\hline & married & 160 & 34.1 & 1624 & 57.6 \\
\hline \multirow[t]{6}{*}{ educational level* } & 1 & 130 & 30.9 & 584 & 21.7 \\
\hline & II & 79 & 18.8 & 749 & 27.9 \\
\hline & III & 115 & 27.3 & 478 & 17.8 \\
\hline & IV & 42 & 10.0 & 289 & 10.7 \\
\hline & v & 28 & 6.7 & 250 & 9.3 \\
\hline & VI & 27 & 6.4 & 339 & 12.6 \\
\hline \multirow[t]{7}{*}{ work situation* } & paid job & 163 & 36.1 & 1221 & 45.1 \\
\hline & running household & 45 & 10.0 & 498 & 18.4 \\
\hline & student & 63 & 14.0 & 174 & 6.4 \\
\hline & retired & 18 & 4.0 & 408 & 15.1 \\
\hline & invalidity pension & 20 & 4.4 & 158 & 5.8 \\
\hline & unemployed & 85 & 18.8 & 152 & 5.6 \\
\hline & social security & 57 & 12.6 & 98 & 3.6 \\
\hline
\end{tabular}

- Chi-square test, $p<0.05$ 


\subsection{Results}

\subsubsection{Mortality}

Mortality among Surinam males aged 5-14 and 75 years and older was higher than among Dutch males from 1986 to 1991 (figure 6). Between the age of 15 to 34 the increase in mortality was stronger among Surinam males, and after the age of 35 the increase was equal to Dutch males. Mortality among Surinam females was higher than among Dutch females in all age categories.

- Figure 6. Mortality in Surinam and Dutch men and women, 1986-1991

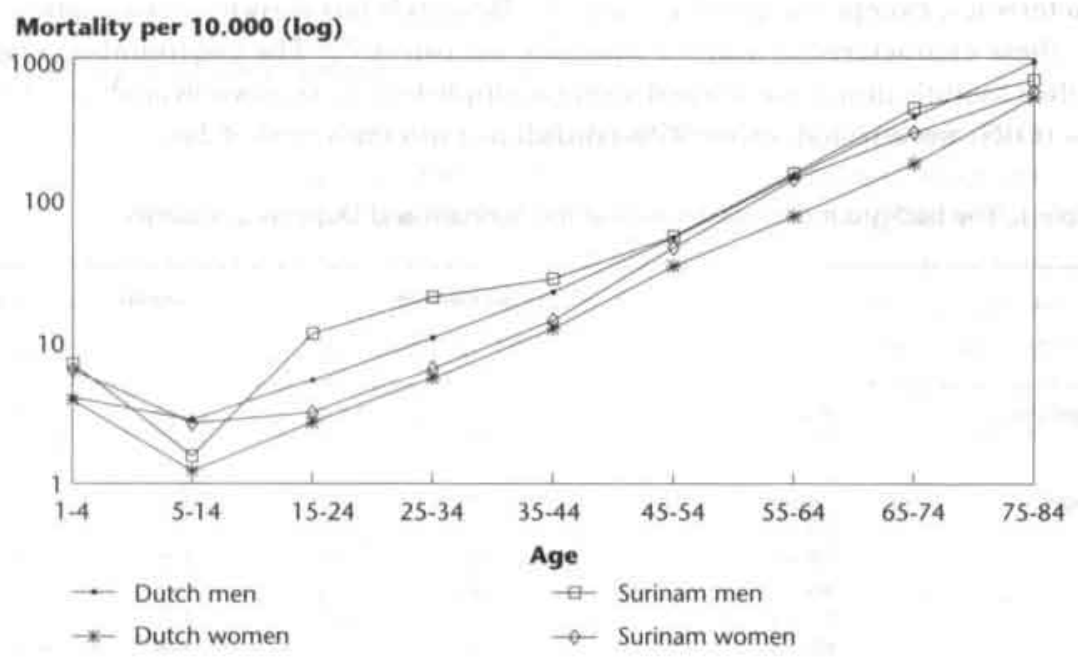

Separate SMRs were calculated for males and females in the age categories 1-34 and 35 years and above, because of these different patterns (table 2). The standardized mortality in Surinam males aged 1-34 was $81 \%$ higher than in Dutch males $(\mathrm{SMR}=180.6,95 \%$-CI 143.2-224.8). The mortality rates were clearly higher in the age categories $15-24$ and 25-34: 11.6 and 20.9 per 10,000 , against 5.4 and 10.8 among the Dutch. In the age category 35 years and above the mortality among Surinam and Dutch males was equal (SMR=103.8, 95\%-CI 89.9-119.3).

The standardized mortality in Surinam females aged 1-34 compared to Dutch females was $34 \%$ higher, though not statistically significant ( $\mathrm{SMR}=133.9 .95 \%$-CI 92.2-188.0). Surinam women aged 35 years and over counted for $39 \%$ more deaths than Dutch females (SMR=139.1, 95\%-CI 121.0-159.2). Mortality was higher especially in the age categories 55-64 and 65-74: mortality rates of 141.5 and 298.1 per 10,000 respectively, against 77.4 and 181.3 among the Dutch.

General SMRs for the sum of all age categories of Rotterdam Surinamese are given in table 2, although the mortality was not distributed homogeneously among all ages 
as was mentioned above. Among males of Surinam origin from Rotterdam the mortality was $18 \%$ higher and among Surinam females $38 \%$. These findings are comparable to the national statistic of a raised mortality, standardized for gender and age, of $21 \%$ among the Surinam inhabitants of the Netherlands in $1990 .^{*}$

- Table 2. SMRs and 95\%-confidence intervals (CI). Surinamese (index population) versus Dutch (standard population), 1986-1991

\begin{tabular}{|lllll|}
\hline & males & & females & \\
\hline age & SMR & $95 \%-\mathrm{Cl}$ & SMR & $95 \%-\mathrm{Cl}$ \\
\hline total & 118.2 & $104.7-132.9$ & 138.4 & $121.6-156.9$ \\
$1-34$ & 180.6 & $143.2-224.8$ & 133.9 & $92.2-188.0$ \\
$35+$ & 103.8 & $89.9-119.3$ & 139.1 & $121.0-159.2$ \\
\hline
\end{tabular}

\subsubsection{Self-rated health and reported health care use}

Crude Odds Ratios of the relationship between country of origin and health outcome are given in table 3 (model I). More Surinam than Dutch respondents considered their health to be moderate poor or poor, and experienced psycho-social problems. Moreover more Surinam respondents had contact with their GP or the RIAMHC. When gender and age was accounted for, the Odds Ratios stayed significant, except for use of the RIAMHC, (model II). The prevalences of the judgement of health as moderate poor or poor, and of contact with the GP at least once the last two months are given in figure 7. It can be seen that it is mainly in the oldest age category (35-75) that the Surinamese and Dutch differ with respect to these outcome variables.

When marital status, educational level and job participation were entered in the regression models, the Odds Ratios changed towards 1, meaning a less strong relationship between country of origin and health outcomes (table 3, models III. IV and V). In the complete regression model V, more Surinamese than Dutch respondents rated their health as moderate poor or poor ( $O R=1.50,95 \%$-CI 1.14-1.96), and more Surinamese had visited their GP $(\mathrm{OR}=1.81,95 \%$-CI 1.36-2.40). Moreover, they reported more frequent contact with their GP, than the Dutch, an OR of 2.17 (95\%CI 1.23-3.84), corrected for the background characteristics, meaning that more Surinamese compared to the Dutch, reported contact at least three times with their GP in the last two months. The association between country of origin and psychosocial problems was not significant in the full regression model (table 3).

Effect modification through categories of marital status was established, changing the association between country of origin and self-rated health (table 4). Among widowed people, the Surinamese rated their health most frequently as moderate to poor, com- 
- Figure 7 Differences between the Surinamese and Dutch with respect to their health rated as moderate poor to poor, and contact with the GP, at least once the last two months

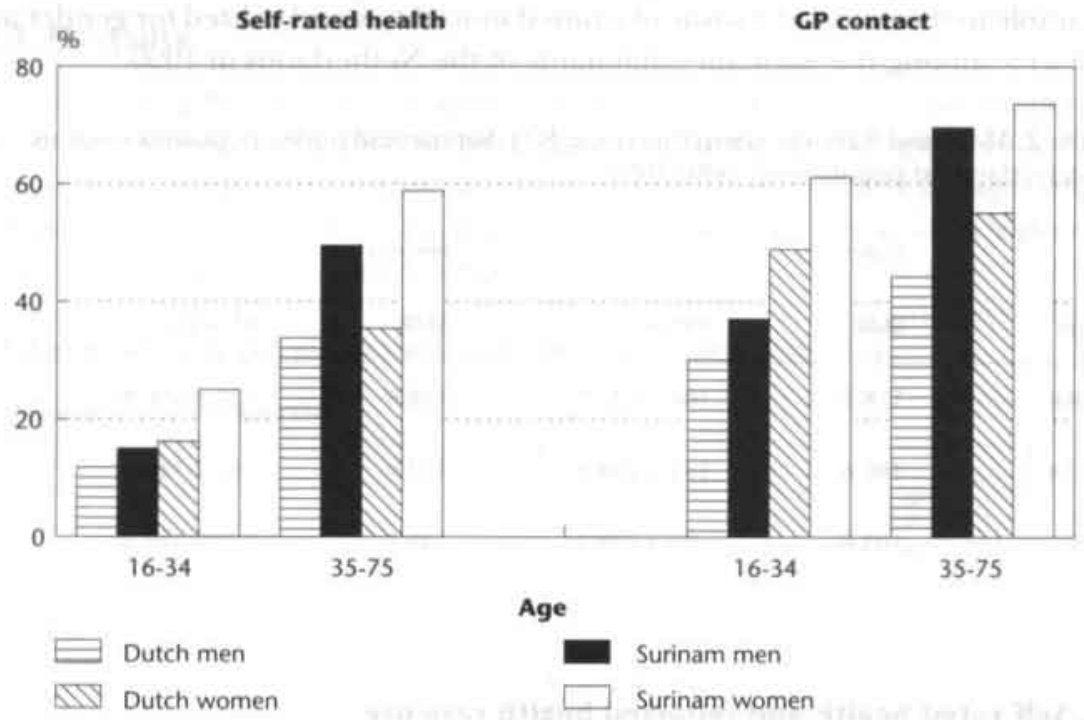

- Table 3. The association between outcome measures and country of origin, corrected for potential confounders (Odds Ratios, Surinamese (index population), Dutch (reference population) logistic regression analysis)

\begin{tabular}{|c|c|c|c|c|c|c|c|c|}
\hline & \multicolumn{2}{|c|}{$\begin{array}{l}\text { moderate poor to } \\
\text { poor health } \\
n=2945 \text {, } \\
\text { missing }=352\end{array}$} & \multicolumn{2}{|c|}{$\begin{array}{l}\text { psycho social } \\
\text { problems } \\
n=1936 \text {, } \\
\text { missing }=290\end{array}$} & \multicolumn{2}{|c|}{$\begin{array}{l}\text { GP use } \\
n=1984, \\
\text { missing }=172\end{array}$} & \multicolumn{2}{|c|}{$\begin{array}{l}\text { RIAMHC use } \\
n=1421 \text {, } \\
\text { missing }=245\end{array}$} \\
\hline & OR & $95 \%-\mathrm{Cl}$ & OR & $95 \%-\mathrm{Cl}$ & OR & $95 \%-\mathrm{Cl}$ & OR & $95 \% \cdot \mathrm{Cl}$ \\
\hline 1 & 1.29 & $1.02-1.62$ & 1.63 & $1.23-2.16$ & 1.77 & $1.36-2.29$ & 1.95 & $1.08-3.52$ \\
\hline II & 1.93 & $1.51-2.47$ & 1.63 & $1.22-2.18$ & 2.13 & $1.63-2.79$ & 1.66 & $0.90-3.04$ \\
\hline III & 1.74 & $1.35-2.24$ & 1.48 & $1.10-1.98$ & 2.02 & $1.54-2.65$ & 1.27 & $0.68-2.39$ \\
\hline IV & 1.58 & $1.22-2.05$ & 1.36 & $1.00-1.84$ & 1.84 & $1.39-2.43$ & 1.08 & $0.57-2.06$ \\
\hline v & 1.50 & $1.14-1.96$ & 1.23 & $0.90-1.69$ & 1.81 & $1.36 \cdot 2.40$ & 0.98 & $0.50-1.90$ \\
\hline
\end{tabular}

independent variables in logistic regression models:

1 country of origin

II country of origin + gender + age

III country of origin + gender + age + marital status

IV country of origin + gender + age + marital status + educational level

$\checkmark$ country of origin + gender + age + marital status + educational level + work situation 
pared to the Dutch. Among those who had never married, no significant difference was found as to self-rated health between the Surinamese and Dutch. The high amount of Surinamese students who experienced psycho-social problems, compared to Dutch students is striking. Among people receiving social assistance more Dutch than Surinamese respondents experienced psycho-social problems. The raised contact with the GP at least one time during the last two months, by Surinamese respondents compared to the Dutch, was highest among the age category 55-75. The strength of the relationship decreased across the age categories and GP use did not differ between the Surinamese and Dutch in the youngest age category. With respect to RIAMHC use, more male Surinamese than Dutch respondents reported contact. Among females, less Surinamese than Dutch respondents had contact with the RLAMHC.

- Table 4. Effect modification of country of origin and other background characteristics on the outcome variables (Odds Ratios, Surinamese (index), Dutch (reference))*

\begin{tabular}{|llll|}
\hline outcome & strata & OR & \\
\hline self-rated health & widowed & 3.62 & $95 \%-\mathrm{Cl}$ \\
& divorced & 2.58 & $0.69-19.00$ \\
& married & 2.00 & $1.35-4.93$ \\
& unmarried & 0.84 & $1.32-3.02$ \\
psycho-social & student & 3.96 & $0.54-1.30$ \\
problems & running household & 1.49 & $1.73-9.04$ \\
& unemployment benefit & 1.33 & $0.60-3.70$ \\
& paid job & 1.00 & $0.62-2.85$ \\
& retired & 0.92 & $0.60-1.67$ \\
& invalidity pension & 0.88 & $0.18-4.65$ \\
GP use & social security & 0.57 & $0.23-3.35$ \\
& S5-75 & 3.97 & $0.23-1.46$ \\
& $45-54$ & 2.57 & $1.14-13.90$ \\
& $35-44$ & 2.87 & $1.12-5.87$ \\
& $25-34$ & 1.51 & $1.57-5.25$ \\
RIAMHC use & $16-24$ & 1.11 & $0.90-2.51$ \\
& male & 2.40 & $0.66-1.87$ \\
& female & 0.49 & $0.94-6.13$ \\
& & & $0.19-1.28$ \\
\hline
\end{tabular}

- Effect-modification or interaction was studied using logistic regression models, including one outcome variable, country of origin and all background characteristics, to which one interaction term was added (product of country of origin and one background characteristic).

The likelihoodratio-test was used to determine improvement of the model at the significance level of $p<0.10$, when the interaction term was added to the model. 


\subsection{Discussion}

Mortality, perceived health situation and reported use of health care services among Surinam inhabitants of Rotterdam of Dutch nationality were studied. First, a few comments on the results should be given. As the non-response was not studied, selective response by for instance less healthy Surinamese has to be considered. Another restriction is that the results do not apply to the little group of inhabitants of Surinam nationality. Because the measurements used were not validated in the Surinam population, the difference in health status found in this study may be explained by the cultural differences between the Surinamese and the Dutch. For a better understanding of our findings, factors which are valid specifically for immigrants have to be considered, like selective emigration of healthy populations, exposure to determinants of illness in the home country, the influence of adoption of new lifestyles and exposure to determinants in the country of immigration, and genetic factors. ${ }^{19}$

More detailed research into causes of death could shed some light on the mortality rates found, however these causes cannot be determined using data from the registrar's office. The following questions can be asked with regard to the results of the mortality findings. Can a reduced prevalence of traffic accidents explain the lower mortality among boys between 5 to 14 years of age? Research into children of the city of The Hague showed a lesser incidence of traffic accidents among Surinam compared to Dutch children. ${ }^{29}$ Can external causes of death (homicide, suicide, accidents) explain the higher mortality among Surinam men 15 to 34 years of age? In this age group external causes of death account for $53 \%$ of mortality in the male general population. ${ }^{21}$ Research into causes of mortality in Surinam women 55-74 years is necessary to explain the raised SMR.

The more negatively rated subjective health and elevated GP use, even after correction for educational level and work situation, are an indication of a less favourable health status of the Surinamese. Not only had more Surinam citizens contact with their GP than Dutch, the contacts were also more frequent. The need for medical aid could even be higher, because use of alternative treatments, like 'winti-rituals', was not covered by the questionnaire. More Surinam than Dutch students experienced psycho-social problems. Moreover Surinam males more often reported use of RIAMHCs compared to Dutch males. Research into the use of psychiatric hospitals reported higher use among Surinam males, which supports our findings. ${ }^{2}$ The backgrounds of psycho-social problems and reasons for GP use need to be studied more in depth, however the difference in meaning that the Surinam people probably attach to their problems must be taken into account. If possible Creoles need to be distinguished from Hindus in future research.

The research question whether educational level and work situation explain the difference in subjective health and health care use, can only be answered partly. The difference in psycho-social health and use of RIAMHCs disappears when controlling in the logistic regression model for the background characteristics (table 3 ). With 
respect to self rated health and GP use, the association between country of origin at the one side, and self rated health and GP use at the other, becomes weaker, however, a difference between the Surinamese and Dutch still exists. The deprived health situation of the Surinamese may be explained by other factors, like stress of migration. ${ }^{23}$ Higher mortality in lower socio-economic populations is known from research..$^{4.24 .25}$ The influence of socio-economic status on mortality could not be examined in this study.

\subsection{Conclusion}

Excess mortality was found especially among Rotterdam Surinam males aged 15-34 years and Rotterdam Surinam females aged 55-74. A study into the causes of death is recommended. Surinam inhabitants more often judged their health as (moderately) poor and visited their GP. More Surinam than Dutch students experienced psychosocial problems and more Surinam males reported RIAMHC use, however because of the unknown validity of these outcome measures in immigrant groups, these findings have to be treated carefully. The educational level and work situation only explain in part the poorer health situation of the Surinamese. The backgrounds of the psycho-social problems and reasons for GP use among the Surinamese should be studied in more detail. 


\section{References}

1. Ferrier JM. De Surinamers, Muiderberg: Coutinho, 1985.

2. Rijkschroeff BR, The GT. Samen gezond: ervaringen van migranten met de gezondheidszorg in Nederland. Capelle a/d IJssel: Labyrint, 1992.

9. Centraal Bureau voor de Statistiek en Universiteit van Amsterdam. De leefsituatie van Surinamers en Antillianen in Nederland, 1985: kerncijfers. 's-Gravenhage: Staatsuitgeverij, 1988.

4. Mackenbach JP, Maas PJ van der. Sociale ongelijkheid en verschillen in gezondheid: een overzicht van de belangrijkste onderzoeksbevindingen. In: Wetenschappelijke Raad voor het Regeringsbeleid. De ongelijke verdeling van gezondheid: verslag van een conferentie gehouden op 16-17 maart 1987. 's-Gravenhage, 1987: 59-93.

5. Blanken P. Surinaamse ouderen in Rotterdam: een verkennend onderzoek naar de gezondheid, naar het gebruik van gezondheidszorgvoorzieningen, en naar de sociale contacten die zij onderhouden. Rotterdam: Gemeentelijke Gezondheidsdienst Rotterdam, afdeling Geestelijke Volksgezondheid, 1987.

6. Uniken Venema P, Klaus J, Reelick F. Gezondheid van Surinamers in Rotterdam. Epidemiologisch Bulletin 1990;23:11-16.

7. Wieringen J van. Morbiditeitspatronen en huisartsgeneeskundig handelen bij etnische groeperingen. Amsterdam: GG \& GD, 1986.

8. Tas, RF]. Surinaamse en Antilliaanse bevolking in Nederland, 1 januari 1991. Mndstat Bevolk (CBS) 1992;40:6-8.

9. Zundert A van. Prognose etnische minderheden Rotterdam, 2006. Rotterdam: Centrum voor Onderzock en Statistiek, 1992.

10. Veling SHJ, Sturmans F. Standaardisering van morbiditeits- en mortaliteitscijfers en indices. Tijdschr Soc Gezondheidsz 1981;59:271-278.

11. Maas PJ van der, Habbema JDF. Standaardiseren van ziekte-en sterftecijfers; mogelijkheden en beperkingen. Tijdschr Soc Gezondheidsz 1981;59:259-270.

12. Gardner MJ. Altman DG, Statistics with confidence: confidence intervals and statistical guidelines. London: British Medical Journal, 1989.

13. Reelick NF. Een gezondheidsuitstapje met de Omnibus: resultaten van het gezondheidsgedeelte van de Omnibusenquête 1987. Rotterdam: GGD Rotterdam c.o., afdeling Epidemiologie, 1988.

14. Reclick NF, Teeuwen JHM. Gezondheid en welzijn in Rotterdam: resultaten van het gezondheidsgedeelte van de Rotterdamse Omnibusenquête 1988. Rotterdam: GGD Rotterdam e.o., afdeling Epidemiologie, 1989.

15. Reelick NF, Lamers LM. Omnibusenquête 1989: wijkverschillen blijven. Rotterdam: GGD Rotterdam e.o., afdeling Epidemiologie, 1991.

16. Bradburn NM. The structure of psychological well-being. Chicago: Aldine, 1969.

17. Ormel H. Moeite met leven of een moeilijk leven: een vervolgonderzoek naar de invloed van psychosociale belasting op het welbevinden van driehonderd Nederlanders. Proefschrift. Groningen: Konstapel, 1980.

18. Hosmer DW, Lemeshow S. Applied logistic regression. New York: Wiley, 1989.

19. Marmot MG, Adelstein AM, Bulusu L. Lessons from the study of immigrant mortality. Lancet $1984 ; 393(\mathrm{I}): 1455-1457$. 
20. Junger M, Steehouwer LC. Verkeersongevallen bij kinderen uit etnische minderheden. 'sGravenhage: WODC, Ministerie van Justitie, 1990.

21. CBS. Jaargegevens mortaliteit. Mndber Gezondheid (CBS) 1993;12(3):10-11.

22. Uniken Venema HP, Wierdsma Al. Opnames van migranten in psychiatrische ziekenhuizen. Tijdschr Soc Gezondheidsz 1993;71:37-43.

23. Kliewer E. Epidemiology of diseases among migrants. Paper presented at the International Organization for Migration Conference on Migration and Health. Brussels, 1992.

24. Marmot MG, McDowall ME. Mortality decline and widening social inequalities. Lancet $1986 ; 335$ (II) $: 274-276$.

25. Oers JAM van, Teeuwen JHM, Sociaal-economische status en sterfteverschillen tussen Roterdamse buurten. Tijdschr Soc Gezondheidsz 1991;69:55-60. 


\section{Chapter 3}

Peer-led AIDS education aimed at Turkish and Moroccan men: objectives, determinants and practice

epidemiological diagnosis intervention development 


\section{Abstract}

A study was conducted into the AIDS education program aimed at male Turkish and Moroccan immigrants in the Netherlands. The AIDS education was given in the native language by peers. The aims of the study were to establish the actual program targets, to examine determinants of condom use among Turkish and Moroccan men, and to make recommendations for program improvement. Program objectives in the field of knowledge of HIV-transmission, the risk of getting AIDS, and condom use were established, using the nominal group technique. Registration of 48 education sessions in coffee houses and mosques showed that the most attention to condom use was paid by the Moroccan educators. The Turkish educators stressed knowledge of HIV transmission. Frequenters of coffeehouse and mosques filled out questionnaires before they received the AIDS education to examine predictors of the intention to use condoms. The following predictors of intention of condom use were found: misunderstandings about HIV transmission and beliefs of the risk of getting AIDS. Moreover, the barrier of diminished satisfaction with sex if using a condom, and self-efficacy, were predictors of the intention to use condoms among married men and men aged 30 years and above. The continuation of knowledge transfer and change of beliefs with regard to HIV transmission and susceptibility to AIDS is recommended. Ample discussion of condom use during the education session is advised and attention has to be paid to self-efficacy with regard to condom use among subgroups. A closer study into the motives for condom use among unmarried and younger Turkish and Moroccan men is recommended, considering the absence of a clear pattern of determinants of condom use. 


\section{Peer-led AIDS education aimed at Turkish and Moroccan men}

\subsection{Introduction}

Immigrant groups in the Netherlands, among others Antillian/Aruban, Surinam, Turkish, Moroccan and Cabo Verdian, have been educated about AIDS in a special program since 1989. Men recruited from these groups have been trained as peer educator. These peer educators speak the native language and are familiar with group norms and values about sexuality and AIDS. This article contains a description of peerled AIDS education for Turkish and Moroccan men. AIDS education for immigrants was thought to be important for various reasons. The general mass-media campaigns did not reach the immigrants, due to their insufficient mastery of the Dutch language and use of different media like minority programs on radio and television, satellite channels and native newspapers. Moroccans hardly read newspapers, as opposed to the Turks, because of illiteracy and a tendency not to read the available literature. Research into the occurrence of Sexually Transmitted Diseases (STD) among visitors to STD clinics, showed a raised incidence among Turkish and Moroccan men, compared to the Dutch. ${ }^{1-4}$ Divergent use of these easy accessible clinics by immigrant groups may explain this result, however inconsistent or absent use of condoms should be considered. Qualitative research into relationships and sexuality in Turkish and Moroccan men showed practical and emotional objections to condom use. ${ }^{3,6}$ Condom use was considered to be inconvenient, the smell of condoms was found to be unpleasant, and condom use was associated negatively with extramarital sex. Turkish and Moroccan men turned out to be well informed about the protective effect of condom use against AIDS, however persistent misunderstandings regarding HIV transmission existed. A change could be observed among young Turkish and Moroccan adolescents. ${ }^{7}$ The reported condom use had increased between 1990 and 1995 to the Dutch adolescents' level. Moreover, the attitude toward sex before marriage had become more liberal, though still less liberal than among Dutch adolescents.

The following targets were formulated at the start of the peer-led AIDS education program: making AIDS and sexuality discussible, calling attention to AIDS prevention, reducing unnecessary fear for HIV infection, and improving knowledge of AIDS. The 'Nederlands Instituut voor Gezondheidsbevordering en Ziektepreventie' (NIGZ, National Institute for Health Promotion and Illness Prevention) coordinates the AIDS education for immigrants at the national level, being part of the program 'Voorlichting Eigen Taal en Cultuur' (VETC, Education in the Native Language and Culture). ${ }^{8}$ Program execution at the local level is organized by the public health services. The program is an outreach program and the peer educators visit coffeehouses, mosques, community centres etcetera. The meetings are rather unstructured, people are free to join or leave the education session. Peer-led AIDS education is also given in a more structured form in courses for new settlers, basic education courses or health education courses for immigrants. Moreover, visitors to festivals and other events are educated about AIDS by peer educators. 
The study into the peer-led AIDS education given in coffeehouses and mosques is described in this article. The aim was to contribute to future improvement of the education practice. The study consisted of two parts: the objectives pursued in practice were determined in study 1 . The determinants of the intention to use condoms by Turkish and Moroccan visitors were examined in study 2 , using the pre-tests of the evaluation study conducted from 1996 to $1998 .{ }^{10.11}$ The following research questions are addressed in this article. What were the objectives of peer-led AIDS education for male Turkish and Moroccan men, and to what degree were they discussed during the education sessions? What are determinants of condom use by Turkish and Moroccan men?

\subsection{Methods and materials}

\subsubsection{Study 1: peer educators}

The objectives pursued in practice were studied, using the nominal group technique. Seven Turkish and Moroccan peer educators and four coordinators, who were also immigrants, participated in the group discussion. The nominal group technique offers a procedure to explore opinions about a central question. ${ }^{12,13}$ The central question was 'What have the frequenters of coffeehouses learned from your education sessions during the last year?'. The participants had to give six learning objectives in as concrete and measurable form as possible. They were allowed to explain the objectives and were asked to make a list in order of importance of the objectives. A postal delphiround was conducted afterwards, asking the participants whether objectives should be added or changes should be made in the ranking result of the group interview.

A top 5 of the highest ranked learning objectives was formed. The degree to which the five objectives were discussed during 48 meetings in coffeehouses and mosques was studied. The peer educator was accompanied by a colleague, called a research assistant, who had to judge on a five point scale the degree to which the objectives were dealt with, using a registration form.

\subsubsection{Study 2: participants}

The Turkish and Moroccan participants at the 48 education sessions in coffeehouses and mosques were asked to fill out a short questionnaire to evaluate the effectiveness. ${ }^{10.11}$ The questionnaire was called a 'quiz' to lower the threshold of participation in the study. The pre-test and post-test were assigned randomly to the education sessions. The analysis of determinants of condom use among respondents who were pre-tested before they received the AIDS education is described in this article, i.e. frequenters of 14 Turkish and 10 Moroccan coffeehouses and mosques in the cities of Amsterdam, Rotterdam, The Hague and Utrecht. The respondents filled out the short questionnaire by themselves, though they were helped by the research assistant if necessary. Questions were read out loud before the group or per table and the position of answer categories was pinpointed. The peer educators were trained in how 
to organize the data collection. Participation in the questionnaire was anonymous. Dutch, Turkish and Arabic Moroccan versions of the questionnaire were available.

Questions related to the learning objectives were included in the questionnaire, which was developed in collaboration with the peer educators. They were tested at three education sessions after which adaptations were made. The questionnaire had to be short and simple, because of the unstructured setting of the localities and the expected low educational level of the visitors. The number of items per learning objective was limited and a maximum of three answer categories was used. The questions had to be neutral. Explicit, suggestive references to sexual habits of the respondents were experienced as impolite. General questions without for instance suggesting that the respondent was involved in extramarital contacts or with different sexual partners could be included. The intention to use condoms in future if the respondent had a new partner could also be asked. Complex formulations like conditional statements, e.g. 'If you are in a situation where you have planned to raise the topic of condom use with your partner, would you.....?', were experienced as too difficult by the poorly educated respondents.

The questionnaire included items on beliefs about HIV transmission, risk of attracting AIDS and the use of condoms. These beliefs are equal to the determinants of behaviour of the Health Belief Model. ${ }^{1+16}$ The Health Belief Model is suitable when the behaviour change pursued is not too complex, like drawing people's attention to the danger of AIDS and the necessity of prevention. ${ }^{17}$ Two groups of factors in this model determine people's behaviour, i.e. the perceived threat of the illness under consideration and the expectations with regard to the barriers and benefits when performing actions which prevent or relieve the illness (figure 8 ). The perceived threat of AIDS was in this study distinguished into risk appraisal for AIDS infection and beliefs and misunderstandings about HIV transmission. Misunderstandings can influence people's right or wrong beliefs about the threat of AIDS. The determinant of perceived severity of the illness in the Health Belief Model was not studied and considered constant among the respondents, because of a $100 \%$ mortality of AIDS. Moreover the effect on the following expectancies with regard to condom use were studied: the barrier of diminished satisfaction with sex if using condoms, the barrier of buying condoms, the benefit of the protective effect of condoms and, perceived self-efficacy to use condoms. Perceived self-efficacy to perform the behaviour, a concept from social learning theory, was added to the Health Belief Model to increase its explanatory power. ${ }^{14} \mathrm{~A}$ person's self-efficacy or belief that one can successfully execute the behaviour is a strong predictor for performing the desired behaviour. ${ }^{18}$ The total of beliefs and the evaluation of beliefs determine a person's attitude toward condom use. The beliefs will differ between groups with different social demographic characteristics like gender, age or ethnicity. Cues will eventually activate the desired behaviour, for instance physical complaints or education (see figure 8). 


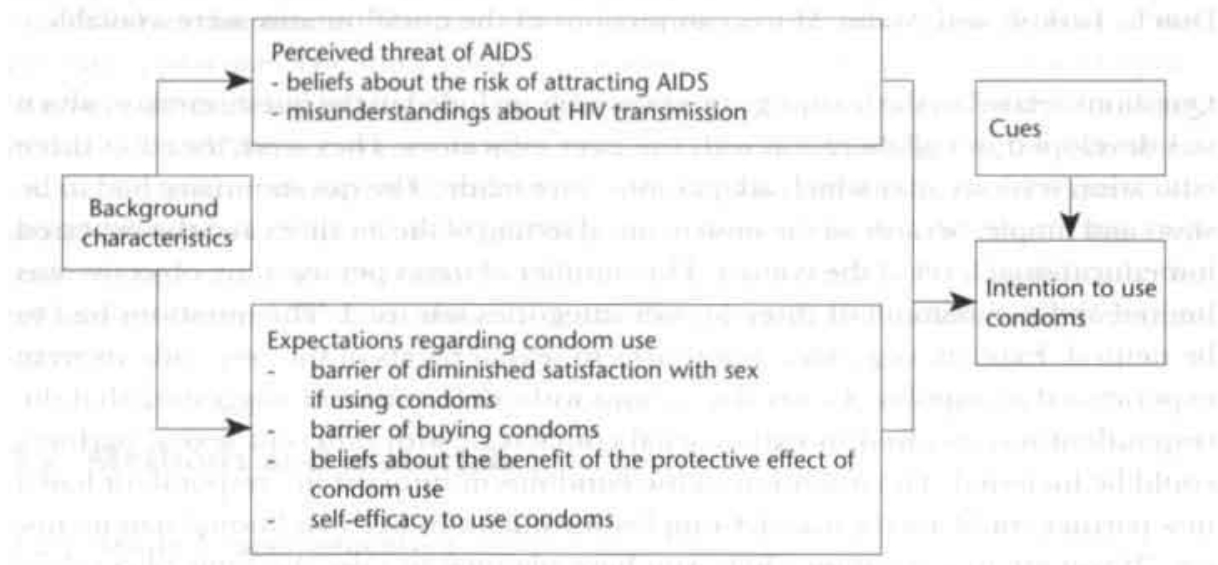

(Source: Rosenstock IM, Strecher Vl, Becker MH. The health belief model and HIV risk behaviour change. DiClemente R], Peterson IL (red.). Preventing AIDS: theories and methods of behavioural interventions. New York: Plenum Press, 1994)

\section{Statistical analysis}

Factor analysis led to the following scales measuring perceived threat and beliefs about condom use. The scale 'misunderstandings regarding HIV transmission' consisted of three items, for example 'Can the AIDS virus be transmitted by kissing?' $(\alpha=0.56)$. Beliefs about the risk of AIDS infection was asked using a 6 item scale, for example 'Can AIDS only be found in homosexual men?' $(\alpha=0.60)$. The scale 'benefit of the protective effects of condom use' included 4 items, like 'Does a condom protect against the AIDS virus?' ( $\alpha=0.51$ ). Two items were used to measure the perceived barrier of diminished satisfaction of sex if using a condom, i.e. 'making love using a condom is less satisfying' and 'making love using a condom is not genuine' $(\alpha=0.66)$. The barrier of buying condoms was measured using the item: 'I find it difficult to buy condoms'. Self-efficacy was measured using one item: 'I know exactly how to use a condom'. Intention to use condoms was measured using one item: 'I think I will use a condom in future if I have a new partner'. The following background characteristics were asked: ethnic origin, age, marital status and previous participation in AIDS education.

The items and scales were dichotomized because of the limited number of answer categories and the skewness of the answers. A high, desirable score was coded 1 and a low, undesirable score 0 . The association between intention to use condoms and its determinants was analyzed univariately. Multivariate logistic regression analysis was used, to account for the effect of the other determinants. Two-way interactions between determinants and background characteristics were tested to assess the strength of the relationship between the intention and determinant within subgroups adding one interaction term to the model including all determinants $(\mathrm{p}<0.10)$. Odds Ratios (ORs) were tested using 95\%-confidence intervals (95\%-CIs). The intention to use 
condoms is higher in the population scoring high on the determinant measure, compared to the group scoring low, if the OR exceeds value 1. A reverse relationship is found if the OR is smaller than 1. A relationship is lacking if the OR equals 1 . The statistical package SPSS for Windows was used.

\subsection{Results study 1: the AIDS education objectives}

The peer educators and coordinators mentioned 17 different learning objectives in the group interview. They listed the objectives in order of ranking, leading to a top 5 of objectives valued as most important (table 5 ). The top 5 actually included six objectives, because the learning objectives 'prevention of misunderstandings and unnecessary fears' and 'demonstration of condom use' ended equal. The objective 'familiar with ways of HIV transmission', which was valued as most important, and the fifth mentioned objective 'prevention of misunderstandings and unnecessary fears' refer to the factor perceived threat in the Health Belief Model. Objectives 2 to 4 refer to beliefs about risk of AIDS infection (table 5). The objective 'demonstration of condom use' is more a means than an end. The objective was reformulated into 'a positive attitude and self-efficacy with respect to condom use', because the peer-educators explained that the objective referred to change of skills to use condoms. Moreover, objectives related to beliefs about condom use, i.e. 'aware of the advantages of condom use' and 'a positive attitude toward condom use' were mentioned in the group interview, but ranked seventh and ninth. The top 5 was not changed after the delphi-round by letter. The objectives corresponded with the targets formulated at the start of the peer-led AIDS education program, except for the target 'making AIDS and sexuality discussible' which was ranked eleventh in the nominal group procedure. ${ }^{9}$

- Table 5. Degree to which the objectives are discussed. Mean (M) and standard deviation (s.d.)

\begin{tabular}{|c|c|c|c|c|c|}
\hline & \multirow[t]{2}{*}{ Objective } & \multicolumn{2}{|c|}{ Turkish } & \multicolumn{2}{|c|}{ Moroccan } \\
\hline & & M & s.d. & M & s.d. \\
\hline I. & Familiar with ways of HIV transmission' & 4.15 & 1.23 & 4.25 & 0.91 \\
\hline 2. & $\begin{array}{l}\text { Belief that AIDS is not an illness of } \\
\text { homosexuals alone }\end{array}$ & 3.74 & 1.32 & 4.05 & 0.89 \\
\hline 3. & $\begin{array}{l}\text { Belief that AIDS is not related to country } \\
\text { or colour" }\end{array}$ & 3.81 & 1.42 & 4.55 & 0.69 \\
\hline 4. & $\begin{array}{l}\text { Taking AIDS seriously. Being aware of the } \\
\text { problem and relating it to your situation }\end{array}$ & 3.93 & 1.14 & 4.40 & 1.00 \\
\hline S. & $\begin{array}{l}\text { Prevention of misunderstandings and } \\
\text { unnecessary fears }\end{array}$ & 3.74 & 1.35 & 4.25 & 0.85 \\
\hline 5. & Demonstration of condom use & 3.74 & 1.46 & 4.50 & 1.00 \\
\hline
\end{tabular}

- t-test, $\mathrm{p}<0.0 \mathrm{~S}$

'Range: 1 (not discussed) to 5 (discussed extensively) 
A total of 47 registration forms, filled out by the research assistants, became available. The degree to which the objectives were discussed, was in general scored higher for the Moroccan education sessions than for the Turkish (table 5). The difference between the language groups was significant with respect to the objectives 'belief that AIDS is not related to country or colour' and 'demonstration of condom use'. The different position of the objective related to the condom demonstration between the Moroccan sessions and the Turkish is remarkable (second against last position). The objective 'familiar with ways of HIV transmission' got the highest ranking for the Turkish sessions. The least attention was paid to the belief that 'AIDS is not an illness of homosexuals alone' in both the Moroccan and Turkish sessions.

\subsection{Results study 2: determinants of condom use}

\subsubsection{Response}

The estimated response among the Turks was $40 \%$ (169 respondents) and among Moroccans $67 \%$ (127 respondents). The number of visitors (denominator) was assessed by the research assistant due to the unstructured situation of the education sessions, which only allowed for estimated response rates. The youngest age group was overrepresented among the Turks and slightly overrepresented among the Moroccans, the oldest age groups was underrepresented (table 6). Married men were overrepresented among Turks. The educational level of the response group was higher compared to the general population.

- Table 6. Representativeness of respondents

\begin{tabular}{|c|c|c|c|c|}
\hline & \multicolumn{2}{|c|}{ Turks } & \multicolumn{2}{|c|}{ Moroccans } \\
\hline & $\begin{array}{r}\text { Respondents } \\
N=169\end{array}$ & $\begin{array}{r}\text { General } \\
\text { population }\end{array}$ & $\begin{array}{r}\text { Respondents } \\
N=127\end{array}$ & $\begin{array}{r}\text { General } \\
\text { population }\end{array}$ \\
\hline & 96 & 96 & 96 & $\%$ \\
\hline \multicolumn{5}{|l|}{ Age } \\
\hline $15-29$ & S5 & $' 47$ & 54 & 150 \\
\hline 30-39 & 32 & 34 & 28 & 28 \\
\hline $40-54$ & 14 & 20 & 18 & 22 \\
\hline \multicolumn{5}{|l|}{ Marital status } \\
\hline married & 75 & ' 65 & 46 & ${ }^{1} 49$ \\
\hline unmarried & 25 & 35 & 54 & 51 \\
\hline \multicolumn{5}{|l|}{ Education } \\
\hline no/primary & 36 & ${ }^{2} 46$ & 37 & ${ }^{2} 50$ \\
\hline secondary & 51 & 47 & 46 & 44 \\
\hline poly-technic/university & 14 & 7 & 17 & 6 \\
\hline
\end{tabular}

'Source: CBS, Maandstatistiek van de bevolking 1998;maart:26-33.

"Source: Enquềte beroepsbevolking. In: CBS. Allochtonen in Nederland 1998. Voorburg/Heerlen, 1998. 


\subsubsection{Association with intention}

A significant association was found between intention to use condoms as the one side, and misunderstandings about HIV transmission, beliefs about the risk of AIDS and the perceived barrier of diminished satisfaction if using condoms at the other, using univariate logistic regression analysis (ORs 2.69,2.40 and 1.93 respectively) (table 7).

- Table 7. Determinants of intention to use condoms. Odds Ratios (ORs) and 95\%-confidence intervals $(95 \%-\mathrm{Cl})$

\begin{tabular}{|c|c|c|c|c|}
\hline & $O R^{\prime}{ }_{\text {unwwiste }}$ & $95 \%-\mathrm{Cl}$ & $\begin{array}{r}O R^{2} \text { muninguate } \\
n=246\end{array}$ & $95 \%-\mathrm{Cl}$ \\
\hline $\begin{array}{l}\text { Misunderstandings about HIV } \\
\text { transmission } \\
\text { (little vs. many) }\end{array}$ & 2.69 & $*(1,44-5,02)$ & 2.05 & $*(1.04 \cdot 4.06)$ \\
\hline $\begin{array}{l}\text { Beliefs about the risk of AIDS } \\
\text { (high vs. low) }\end{array}$ & 2.40 & $\cdot(1.46 \cdot 3.97)$ & 2.06 & ${ }^{\circ}(1.16-3.64)$ \\
\hline $\begin{array}{l}\text { Benefit of protective effect of } \\
\text { condoms (high vs, low) }\end{array}$ & 1.19 & $(0.72-1.96)$ & 0.78 & $(0.44-1.40)$ \\
\hline $\begin{array}{l}\text { Barrier of diminished } \\
\text { satisfaction if using condoms } \\
\text { (low vs. high) }\end{array}$ & 1.93 & $*(1.05-3.56)$ & 1.73 & $(0.90-3.33)$ \\
\hline $\begin{array}{l}\text { Barrier of buying condoms } \\
\text { (low vs, high) }\end{array}$ & 1.63 & $(1.00-2.68)$ & 1.26 & $(0.73-2.19)$ \\
\hline $\begin{array}{l}\text { Self-efficacy to use condorns } \\
\text { (high vs. low) }\end{array}$ & 1.45 & $(0.88-2.37)$ & 1.30 & $(0.74-2.29)$ \\
\hline
\end{tabular}

- The $95 \%$-confidence interval does not comprise value 1 .

$\mathrm{N}$ differs because of missing values.

Odds Ratios corrected for the other determinants in the model. Model Chi² $=23.08, p<0.001$.

Percentage predicted: $65.4 \%$.

Respondents who understood ways of HIV transmission well, intended more often to use condoms if they had a new partner, compared to less informed respondents. The intention to use condoms was higher among respondents who had realistic beliefs about the risk of attracting AIDS, compared to respondents who had litule understanding of the AIDS risk. The intention was higher if respondents perceived the diminished satisfaction related to condom use to be less of a barrier. The barrier of buying condoms was just not related significantly to intention to use condoms and an association was not found between intention at the one side and the perceived advantage of the protective effect of condom use and self-efficacy at the other. The relationship with the barrier of diminished satisfaction if using a condom was no longer significant, when the effect on intention was controlled for the other determinants, using multivariate logistic regression analysis (table 7). The association with misunderstandings about HIV transmission and beliefs about risk of AIDS remained significant. 
Significant interaction effects of determinants and background characteristics on the intention to use condoms are given in table 8 .

- Table 8. Interaction effects of determinants and background characteristics on the intention to use condoms. Odds Ratios (ORs) and 95\%-confidence intervals (95\%-CI)

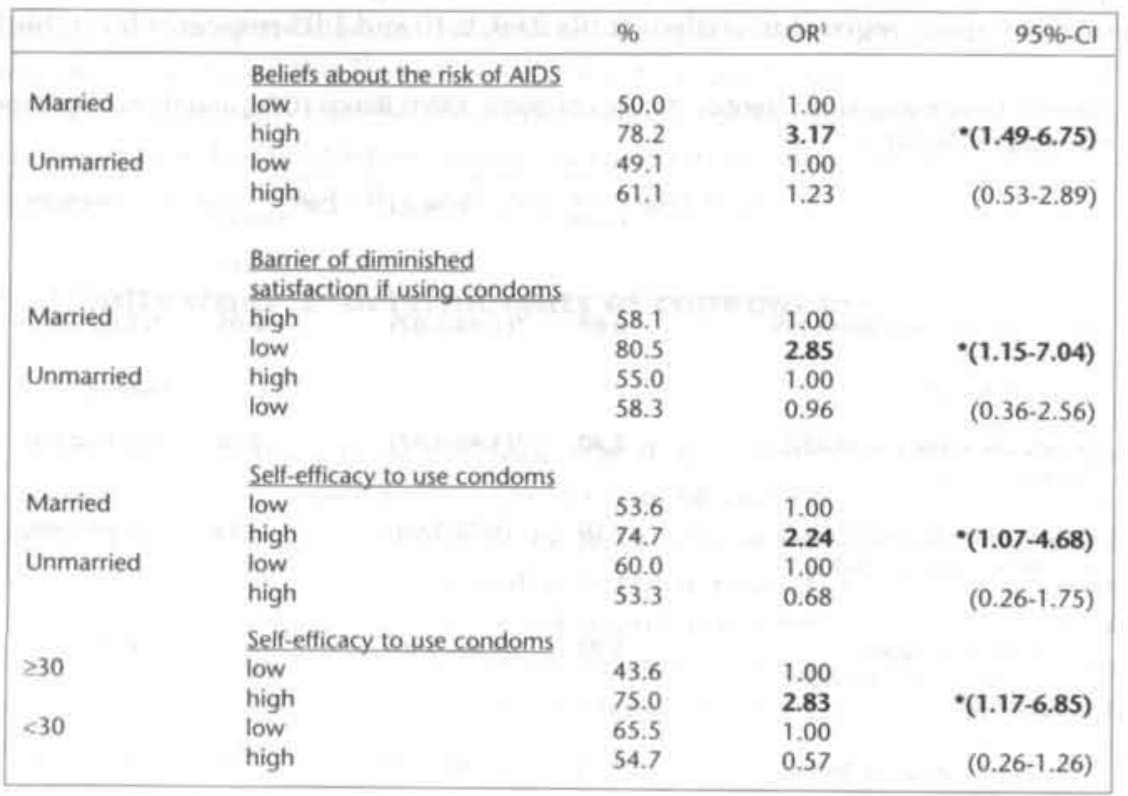

- The 95\%-confidence interval does not comprise value 1.

Odds Ratios within subgroups corrected for the other determinants in the model to which one interaction term was added

The influence of beliefs about the risk of AIDS and the barrier of diminished satisfaction was only found in married Turkish and Moroccan men. Moreover, the intention to use condoms was higher in men with high self-efficacy to use condoms, than in men with low self-efficacy, within the subpopulations of married men and men aged 30 years or over.

A predictive effect of the determinants of condom use was not present in the groups of unmarried and younger men. Criterium for positive intention was the answer category 'certainly'. The proportion of men who where certain to use condoms in the groups of unmarried and younger men was relative low (about 50 to $60 \%$ ) and equalled the proportion respondents who intended to use condoms in the married and older men with low scores on the determinant measures (table 8 ). It should be mentioned though that many unmarried and younger respondents indicated 'probably' if asked for intention to use condoms. Interaction effects of the background characteristics country of origin and former attendance of AIDS education were not found. 


\subsection{Discussion}

A study was carried out into AIDS education aimed at Turkish and Moroccan men, given by peer educators in coffeehouses and mosques. The study consisted of two parts. The objectives pursued in the AIDS education given by the peer educators were examined in study 1, using group interview methods and registration forms. Determinants of the intention to use condoms among the participants of the meetings were examined in study 2, using survey methods. The education objectives and determinants of condom use are discussed jointly in this article to make recommendations for the practice of AIDS education for Turks and Moroccans in future.

The nominal group technique used in study 1, turned out to be suitable for setting objectives of health education in a structured way. The peer educators' knowledge of the field and experience as an intermediate were helpful in registrating the degree to which objectives were discussed during the AIDS education meetings. A drawback of the role of research assistants was their involvement in the education program, making it difficult to maintain distance. The results of study 2 into the determinants of condom use can be generalized in part only, because of the high response of relatively higher, though still low educated, unmarried and young men. The use of a short written questionnaire to study determinants of condom use was satisfactory, however problems related to the low educational level and Muslim background of respondents had to be met. The research assistants had to help poorly educated respondents fill out the questionnaire, despite the brief and to the point formulation of the questions. Direct questions about sexual behaviour, for instance sexual contact with extramarital or different partners, could not be included, as such questions were considered impolite.

The accent of the targets formulated at the start of the peer-led AIDS education was on improving knowledge and awareness of AIDS and prevention, and was similar to the objectives pursued in practice as ascertained in study 1 . Analysis of the registration forms showed attention to objectives in the field of improving knowledge of HIV transmission, and perceived threat of AIDS, i.e. diminishing misunderstandings, and change of beliefs about the risk of AIDS infection. The objectives related to condom use turned out to be less clear in the group interview. Demonstration of condom use was put forward as an objective related to self-efficacy and positive attitudes. The registration showed more attention was paid to the demonstration of condom use in the Moroccan meetings than Turkish.

Study 2 showed many misunderstandings on HIV transmission existing among Turkish and Moroccan men. The program's attention to objectives in the field of knowledge transfer and perceived threat should be maintained, in view of the association between the beliefs about HIV transmission and, among married men, beliefs about the risk of AIDS on the one side and intention to use condoms on the other. Moreover, the intention to use condoms was associated with the barrier of perceived diminished satisfaction if using condoms and self-efficacy. An association with the barrier of buy- 
ing condoms and beliefs about the protective effect of condom use was not found. These results of the analysis of determinants applied to married men and men aged 30 years and over only. Distinct attention to condom use in the education session is advised, however the stage of behavioural change of individuals has to be taken into account. Prochaska and DiClemente's transtheoretical model of change distinguishes pre-contemplators who do not yet consider a change of behaviour, contemplators considering behavioural change, people who are ready to action, and persons whose behavioural change has to be maintained. ${ }^{19}$ Research shows the importance of paying attention to the positive consequences of condom use, to help people move from the pre-contemplation to contemplation stage, whereas the perception of the negative sides of condom use stays constant across all stages of change. ${ }^{20}$ People's self-efficacy seems to predict condom use in the stage of action and should be aimed at if people have moved away from the contemplation stage. ${ }^{20,21}$ The present education practice, stressing knowledge and positive beliefs with respect to condom use, suits the subpopulation of married men who do not yet consider use of condoms. The self-efficacy of married men and men aged 30 years and over, who already use condoms or intend to do so, should be aimed at, when the use of condoms is demonstrated. Relevant topics are skills regarding how to buy condoms, to negotiate the use of condoms when having sex with a partner, and to use condoms in the right way. Targeting the education at specific subpopulations, for instance those visiting prostitutes, is advised.

A systematic pattern of determinants of condom use among unmarried, younger Turkish and Moroccan men could not be proven, however sexual contacts with different partners and the need for AIDS prevention may be expected in this target group. Research in the subpopulation of Turkish men, who had two or more sexual partners in the last six months, showed that persons who had run the risk of HIV infection were older than persons who had not, a mean age of 27.6 years against 23.4 years. The persons who had run the risk had immigrated at an older age to the Netherlands and had settled recently. ${ }^{5}$ The answer of a probable intention to use condoms among the unmarried and younger respondents in our analysis of determinants, may indicate their difficulty with condom use. Their answer will be less ambivalent because the need to use condoms will be more urgent than among married or older men. A closer study among unmarried and younger Turkish and Moroccan men into their motives to use or reject condoms using focus group interviews is recommended. Strategies to promote condom use should be developed in close collaboration with representatives of these target groups. 


\section{References}

1. Laar MJW van de, Sleutjes MPM, Postema CA, Water PA van de. Seksueel overdraagbare aandoeningen bij allochtone bevolkingsgroepen; een oriênterend onderzoek. Ned Tijdschr Geneeskd 1991:135:1542-1547.

2. Hooykaas C, Velde FW van de, Linden MMD van der, Doornum G J van, Coutinho RA. The importance of ethnicity as a risk factor for STD's and sexual behaviour among heterosexuals. Genitourin Med 1991;67:378-383.

3. Hoek JAR van den, Coutinho RA. Seksueel overdraagbare aandoeningen, HIV en AIDS bij migranten. Ned Tijdschr Geneesk 1994;138:2188-2192.

4. Gras M, Hoek A van den. Etniciteit en het risico op Hiv/Aids; inventarisatie van de in Nederland aanwezige migranten groepen die mogelijk een verhoogd risico lopen op Hiv en Aids. Amsterdam: GG\&GD Amsterdam, 1995.

5. Everaert HA, Lamur HE. Alles wat geheim is, is lekker; seksuele relaties en beschermingsgedrag van Turkse mannen. Amsterdam: Het Spinhuis, 1993.

6. Gelder P van, Lamur HE. Tussen schaamte en mannelijkheid; seksuele relaties en beschermingsgedrag onder Marokkaanse mannen. Amsterdam: Het Spinhuis, 1993.

7. Brugman E, Vogels $\mathrm{T}$, Zessen $\mathrm{G}$ van. Trends in sexual risk behavior among Turkish/Moroccan adolecents in the Netherlands 1990-1995. European Journal of Public Health 1997;7:418-420

8. Haastrecht P van. Project Ontwikkeling Aids-voorlichting aan migranten. Jaarverslag 1996. Woerden: NIGZ, 1997.

9. Nationale Commissie Aids Bestrijding. Notitie 'Aids-voorlichting migranten'. Amsterdam: Bureau van de Nationale Commisse Aids-bestrijding, 1988.

10. Kocken P, Brandsma J, Voorham T. Effectiviteit van 'peer-education' over Aids voor en door Turkse en Marokkaanse mannen: Aids-voorlichting in de eigen taal en cultuur (VETC). Rotterdam: GGD Rotterdam e.o., 1999.

11. Kocken P, Brandsma J, Swart W, Voorham T. Effects of peer-led AIDS-education aimed at Turkish and Moroccan male migrants in the Netherlands: a randomized controlled evaluation study. Aangeboden.

12. Ven AH van de, Delbecq AL. The nominal group as a research instrument for exploratory health studies. Am J Public Health 1972;62:337-342.

13. Gilst ECH van, Dueren den Hollander H van, Oers JAM van, Garretsen HFL. Kwalitatieve methoden voor gezondheidsonderzoek. Een vergelijkende studie naar de mogelijkheden voor kwalitatief gezondheidsonderzoek in de buurt. Rotterdam: GGD Rotterdam e.o., 1991.

14. Rosenstock IM, Strecher VJ, Becker MH. The health belief model and HIV risk behavior change. DiClemente RJ. Peterson JL (red). Preventing AIDS: theories and methods of behavioral interventions. New York: Plenum Press, 1994.

15. Janz NK, Becker MH. The health belief model: a decade later. Health Education Quarterly 1984;11:1-47.

16. Vries $\mathrm{H}$ de. Determinanten van gedrag. Damoiseaux V, Molen HT van der, Kok GJ (red). Gezondheidsvoorlichting en gedragsverandering, Assen: van Gorcum, 1993.

17. Nutbeam D, Harris E. Theory in a nutshell. A practitioner's guide to commonly used theories and models in health promotion. Sydney: National Centre for Health Promotion, 1998.

18. Bandura A. Social foundations of thought and action: a social cognitive theory. Englewood Cliffs. N.J: Prentice Hall, 1986. 
19. Prochaska JO, DiClemente CC. Toward a comprehensive model of change. Miller WR, Heather N. Treating addictive behaviors; processes of change. New York: Plenum Press, 1986.

20. Grimley DM, Prochaska GE, Prochaska JO, Condom use adoption and continuation: a transtheoretical approach. Health Education Research 1997:12:61-75.

21. Fisher JD, Fisher WA, Williams SS, Malloy TE. Empirical tests of information-motivation-behavioral skills model of Aids-preventive behavior with gay men and heterosexual university students. Health Psychology 1994;13:238-250. 


\section{Chapter 4}

Effects of peer-led AIDS education aimed at Turkish and Moroccan male immigrants in the Netherlands a randomized controlled evaluation study

epidemiological diagnosis

intervention development

effect evaluation 


\section{A T910isids}

\section{Abstract}

Background: an evaluation study was conducted into AIDS education for immigrants in the Netherlands, given in the native language by peers. Turkish and Moroccan men were trained to educate people from their own ethnic group. The effect of peer education on the perceived threat of AIDS and beliefs about condom use were studied. Methods: places where male immigrants meet (coffeehouses, mosques, bars) were matched and randomly assigned to the experimental and control group. The experimental group filled out a short questionnaire at the end of the education session (post-test), the control group was pre-tested and had the opportunity to follow the AIDS education after participation in the questionnaire. Results: an effect could be established, using multilevel logistic regression analysis, on misunderstandings regarding $\mathrm{HIV}$ transmission $(\mathrm{OR}=5.9,95 \%$ $\mathrm{CI}(2.3-15.3)$ and risk appraisal for HIV infection $(\mathrm{OR}=2.9,95 \%$-CI (1.3-6.3)). The perceived benefit of the protective effect of condom use was affected in men 30 years and older, the perceived barrier of a diminished satisfaction if using condoms was changed among unmarried men, the condom self-efficacy was affected in men who valued peer education as important, and an effect on intention to use condoms was found among Moroccans, Conclusion: continuation of peer-led AIDS education for immigrants and adaption of the message to the needs of specific target groups is recommended. 


\section{Effects of peer-led AIDS education aimed at Turkish and Moroccan male immigrants in the Netherlands}

\subsection{Introduction}

In spite of the progress made in medical surveillance of AIDS, considerable effort still has to be paid to education and behavioral change with regard to safer sex. ' From the start of the AIDS epidemic, difficulties have been encountered in disseminating information about HIV transmission and AIDS prevention among immigrant groups in the Netherlands. The general mass media campaigns did not reach them, due to insufficient mastery of the Dutch language and a tendency not to read the available literature about AIDS. In the late eighties and the beginning of the nineties, with an ongoing AIDS prevention campaign in the Netherlands, the prevalence of sexually transmitted diseases (STDs) was higher among Turkish and Moroccan men compared to Dutch men, and attendance at STD clinics among Turkish men was higher. ${ }^{2-1}$ Among Turks and Moroccans some persistent misunderstandings existed about the transmission of HIV through saliva, mosquito bites and toilet use. Condom use was not common or inconsistent. Qualitative research among Turkish and Moroccan men showed that unsafe sex occurred among the sexually active men. Condom use was viewed as unpleasant and there was resistance to ins use because of the negative association with extramarital sex..$^{5.6} \mathrm{~A}$ change could be observed among young Turkish and Moroccan male students, 11 to 18 years of age. The reported condom use had increased from 1990 to 1995 to the Dutch adolescents ' level.?

Lack of knowledge and presumed risk behaviour were the reasons to start a peer education program in 1989 to prevent AIDS among immigrants in the Netherlands. Men from different ethnic origins, e.g. Turks, Moroccans and Surinamese were trained as peer educator. The education of Turks and Moroccans is central in this article. AIDS education in the native language, allowing for cultural habits, was expected to be advantageous considering the delicate nature of the field dealing with HIV transmission and sexual habits. Use of peer educators is recommended when access to hard to reach populations is pursued. ${ }^{8,9}$ Peer educators, paraprofessionals, community health advisors or lay health advisors as they are sometimes called, act as the link between the public health professional and the tanget group. The peer educator knows the places where the hard-to-reach gather, what health change message is acceptable and how the message can be transferred best. AIDS education by peers is thought to be effective. because of the perceived trustworhtyness of the information source and role modelling. ${ }^{10.11}$ The peer educators act as an example for their fellow citizens. The program was an outreach program and peer educators visited cafes, coffeehouses and mosques where the target group members meet. The aims of the program were to increase knowledge about AIDS, reduce unnecessary fears and misunderstanding and change the determinants of condoms use.

The program of AIDS education in the native language is evaluated in this article. Studies on the effectiveness of AIDS education aimed at immigrants in Europe are 
lacking. Information on beliefs about condom use among non adolescent European migrant groups is scarce. The following research question is addressed in this article: what is the effect of peer-led AIDS education, aimed at male Turkish and Moroccan immigrants, on the perceived threat of AIDS and beliefs about condom use?

\subsection{The AIDS education session}

The AIDS education session took about 1 hour and 15 minutes, including 30 minutes discussion. The peer educator gave an introduction, using slides or posters. He gave information about the incidence of AIDS, spread over the world, viral infection, transmission routes, including intravenous drug use and blood transfusion, heterosexual and homosexual contact, pregnancy, and misunderstandings concerning transmission. With respect to prevention strategies use of condoms was emphasized. Several types of condoms were shown, the availability of condoms was mentioned and use of condoms was demonstrated. The peer educator did not address the sexual habits of the immigrants in an explicit way. Condom use in sexual contacts outside the marriage was promoted, without suggesting that the audience was having extramarital relationships. During the talk and at the end, the audience had the opportunity to ask questions and discuss themes such as how the virus works and symptoms of AIDS. An average of 23 men attended the sessions. The AIDS education in coffeehouses, cafes and mosques was rather unstructured. People who happened to be present were invited to attend the session, and were not always prepared for the AIDS education. In practice people walked in and out, and part of the audience attended the entire session.

The targets of the peer AIDS education program were discussed with program coordinators and peer educators in a qualitative procedure, using the nominal group technique. ${ }^{12,13}$ The following targets were determined: increased knowledge of AIDS, clearance of misunderstandings and unnecessary fears of HIV transmission, a realistic appraisal of the risk of attracting AIDS, including erasing the prejudice regarding AIDS being a disease of homosexuals and a disease related to nationality or culture, and positive beliefs, self-efficacy and intention regarding condom use. These targets are equal to the determinants of behaviour in the Health Belief Model. ${ }^{14,15}$ The Health Belief Model is suitable when the behaviour change pursued is not too complex, like drawing people's attention to the danger of AIDS and the necessity of prevention. ${ }^{16}$ Two groups of factors in this model determine people's behaviour, i.e. the perceived threat of the illness under consideration and the expectations with regard to the barriers and benefits when performing actions which prevent or relieve the illness. The perceived threat of AIDS was in this study distinguished into risk appraisal for AIDS infection and beliefs and misunderstandings about HIV transmission. Moreover the effect on the following expectancies with regard to condom use were studied: the barrier of diminished satisfaction with sex using condoms, the barrier of buying condoms, the benefit of the protective effect of condoms and perceived self-efficacy to use condoms. Perceived self-efficacy to perform the behaviour has been added to the Health Belief Model to increase its explanatory power. ${ }^{14}$ A person's self-efficacy 
or belief that he can successfully execute the behaviour is a strong predictor for performing the desired behaviour. ${ }^{11,17}$

The information transfer about AIDS by the peer educator will have an impact on the individual's appraisal of the risk of AIDS. Viewing others in the process of adopting new behaviours like talking about condoms, may influence the audience's expectations toward that behaviour. The peer educator as a role model demonstrating condoms may affect a person's confidence to perform the desired behaviour."

\subsection{Method}

The setting of cafes and mosques raised some limitations to the design of the evaluation study. Randomization of visitors was not possible. Instead, the localities in which the AIDS education took place were randomly assigned to the experimental and the control group. A stratified matching procedure was used, taking into account the nationality, type of locality (coffeehouse, mosque or other locality), estimated mean age, and degree of conservatism of the audience. A pre-and post-test in a place where people walk in and out during the short time limit of one hour was not possible. The measurement therefore was confined to one pre- or post-test. The visitors to the localities that were assigned randomly to the experimental group received the post-test, the visitors of localities in the control group received the pre-test. The control group was given the opportunity to be educated after participation in the questionnaire. An additional difficulty was that many visitors were not used to filling out forms, among the Moroccans especially some were illiterate. The audience was asked to complete a short questionnaire. The questionnaire was called 'quiz' to lower the threshold of participation in the study. To meet the expected reading problems, the peer educators went in pairs to the localities. One educator was responsible for the educational part. The other assisted people technically in completing the short questionnaire. Questions were read out loud and the position of answer categories in the form were pinpointed, when necessary. Sometimes the assistant educators helped individuals on request. The evaluation study took place in the four biggest cities of The Netherlands. Per city four peer educators (two Turks and two Moroccans) by turns organized the AIDS education or assisted with completing the questionnaire. Participation in the questionnaire was anonymous. Eight localities were matched (four experimental and four control settings) in every city per language group. One city failed to organize AIDS education for Moroccan inhabitants, which adds up to 28 sessions for the experimental and 28 for the control group.

\subsubsection{Measures}

The format and phrases of the questionnaire were simple. The items had to be limited and a maximum of three answer categories was used. Complex formulations like conditional statements were experienced too difficult, e.g. "if you are in a situation that you have planned to raise the topic of condom use with your partner, would you....... Moreover the questions had to be neutral. Explicit, suggestive references to 
sexual habits had to be avoided. The questionnaire was developed in collaboration with the peer educators. A certified agency translated the questionnaire into Turkish and Arabic. Native speakers translated the questionnaire back into Dutch.

The following background characteristics were asked: ethnic origin, age, marital status, duration of stay in The Netherlands, educational level, previous participation in AIDS education and the respondent's opinion on the importance of peer AIDS education in the native language. Factor analysis led to the following scales measuring perceived threat and beliefs about condom use. The scale 'misunderstandings regarding HIV transmission' consisted of three items, for example 'can the AIDS virus be transmitted by kissing?' ( $\alpha=0.66)$. Risk appraisal for AIDS infection was asked using a 6 item scale, for example 'can AIDS only be found in homosexual men?' $(\alpha=0.61)$. The scale 'benefit of the protective effects of condom use' included 4 items, like 'does a condom protect against the AIDS virus?' ( $\alpha=0.56$ ). Two items were used to measure the perceived barrier of diminished satisfaction with sex if using a condom, 'making love using a condom is less satisfying' and 'making love using a condom is not genuine' $(\alpha=0.62)$. The barrier of buying condoms was measured using the item: 'I find it difficult to buy condoms'. Self-efficacy was measured using one item: 'I know exactly how to use a condom'. Intention to use condoms was measured using one item: ' 1 think I will use a condom in future if I have a new partner:

\subsubsection{Analysis}

First, the result of the matching procedure was examined. Differences in background characteristics between the experimental and control group were tested using the Chi-square test $(p<0,05)$. Response rates were established. The outcome measures were dichotomized. The scores on the questionnaire items were analyzed at the level of individuals using the Chi-square test $(\mathrm{p}<0.05)$. A multivariate analysis was conducted using multilevel logistic regression analysis, because the observations were not independent. People visited the same locality, received the education in the same group and shared the same peer educator. In short, they were more alike than members of other groups, which means that the measurements were correlated. Standard logistic regression does not account for this. The estimates of odds ratios of multilevel logistic regression analysis are much alike those of standard analysis, however the standard errors are mostly somewhat higher, leading less often to rejection of the nullhypothesis. ${ }^{18,19}$ All first level background characteristics were included in the multilevel model as independent variables. Being a member of the experimental or control group was the key independent variable. Two-way interactions of this group membership variable and the background characteristics were tested $(\mathrm{p}<0.10)$ and added to the model when significant. Extra-binomial variation was also tested. Next to this model, a more extensive model was tested including the matching variables as second level group characteristics, in order to explain the second level variation. Odds Ratios (ORs) were tested using 95\%-confidence intervals (95\%-CIs). The statistical packages SPSS for Windows and MLn were used. The most accurate method available in MLn was used (PQL, 2nd order). ${ }^{20}$ 


\subsection{Results}

\subsubsection{Response}

In total 24 pairs of localities could be matched with respect to nationality, type of locality, estimated mean age and assessment of degree of conservatism. The number of visitors was assessed by the peer educators, which made estimates of response-rates to the questionnaire possible. The estimated response among the Turks in the experimental group was $54 \%$ and in the control group $40 \%$. The response among the Moroccans was $49 \%$ in the experimental and $67 \%$ in the control group. The experimental and control group did not differ significantly with respect to the background characteristics (table 9). Analysis per nationality showed a younger control group among Moroccans than the experimental group. The response group was fairly comparable to national census data with respect to age and marital status of male Turkish and Moroccan immigrants, however the educational level of the response group was higher compared to data from national surveys among the immigrant groups.

- Table 9. Distribution of background characteristics in the experimental ( $\mathrm{E})$ and control group (C)

\begin{tabular}{|c|c|c|c|c|}
\hline & $\begin{array}{r}E \\
n=293\end{array}$ & & $\begin{array}{r}C \\
n=296\end{array}$ & \\
\hline & $\mathrm{n}$ & (\%) & $\mathrm{n}$ & (\%) \\
\hline \multicolumn{5}{|l|}{ Age } \\
\hline$<20$ & 26 & (10) & 48 & (17) \\
\hline $20-29$ & 115 & (43) & 103 & (37) \\
\hline $30-39$ & 86 & (32) & 83 & (30) \\
\hline$\geq 40$ & 41 & (15) & 43 & (16) \\
\hline \multicolumn{5}{|l|}{ Marital status } \\
\hline married & 174 & (62) & 178 & (62) \\
\hline unmarried & 106 & (38) & 109 & (38) \\
\hline \multicolumn{5}{|l|}{ Education } \\
\hline no & 27 & (10) & 17 & (6) \\
\hline primary & 81 & (29) & 86 & (30) \\
\hline secondary & 139 & (50) & 138 & (49) \\
\hline poly-technic/university & 31 & (11) & 42 & (15) \\
\hline \multicolumn{5}{|c|}{ Duration of stay in the Netherlands } \\
\hline$\leq 3$ years & 30 & (11) & 40 & (14) \\
\hline$>3$ years & 250 & (89) & 244 & (86) \\
\hline \multicolumn{5}{|l|}{ Former AIDS education } \\
\hline yes & 118 & (42) & 100 & (36) \\
\hline no & 162 & (58) & 180 & (64) \\
\hline \multicolumn{5}{|c|}{ Importance attached to peer education in } \\
\hline the native language & & & & \\
\hline important & 201 & (71) & 177 & (64) \\
\hline neutral/unimportant & 84 & (29) & 101 & (36) \\
\hline
\end{tabular}




\subsubsection{Effects}

The scores at the level of individuals per questionnaire item are given in table 10 . The experimental group differed significantly from the control group on the items concerning misunderstandings regarding HIV transmission. In the control group only half of the respondents gave the right answers to the questions, against 70 to $80 \%$ of the respondents of the experimental group. The experimental group in general more often gave the correct answers to the items about risk of AIDS than the control group. The scores on the items about the incubation time of HIV (feeling healthy when infected) and testing of prostitutes were still relatively low after attendance of the education session (experimental group). Most respondents already had positive beliefs about the protective effect of condom use, however the education showed an effect on the belief of the possibility of infection of a life partner when someone has extramarital sexual contacts not using a condom. A difference between the experimental and control group in answers on the items concerning the barrier of diminished satisfaction if using condoms, the barrier of buying condoms, and selfefficacy and intention with respect to condom use, could not be proven.

- Table 10. Scores on the questionnaire items ( $E=$ experimental group, $C=$ control group)

\begin{tabular}{|c|c|c|}
\hline & $\begin{array}{r}E \\
\% \\
\text { right }\end{array}$ & $\begin{array}{r}C \\
\% \\
\text { right }\end{array}$ \\
\hline \multicolumn{3}{|l|}{ Misunderstandings regarding HIV transmission } \\
\hline Can the AIDS virus be transmitted by kissing? (no) & $\bullet 81.2$ & 56.8 \\
\hline Can mosquitos transmit the AIDS virus from one person to the other? (no) & *66.9 & 42.2 \\
\hline Is it possible to get AIDS when using a dirty toilet? (no) & $\bullet 76.1$ & 53.4 \\
\hline Scale (all items right) & $\cdot 58.0$ & 24.3 \\
\hline \multicolumn{3}{|l|}{ Risk appraisal for HIV infection } \\
\hline Can one feel healthy being infected by the AIDS virus? (yes) & $\cdot 36.2$ & 28.4 \\
\hline $\begin{array}{l}\text { Is washing oneself thoroughly after the sexual intercourse protective against } \\
\text { the AIDS virus? (no) }\end{array}$ & $\bullet 81.2$ & 68.9 \\
\hline Are all prostitutes in the Netherlands HIV tested? (no) & 49.5 & 41.6 \\
\hline $\begin{array}{l}\text { Are Turks/Moroccans with different sexual contacts less liable to be infected } \\
\text { with AIDS than the Dutch with different sexual contacts? (no) }\end{array}$ & $\cdot 73.0$ & 64.9 \\
\hline Can AIDS only be found in homosexual men? (no) & $\bullet 84.3$ & 75.0 \\
\hline $\begin{array}{l}\text { Is it possible to prevent AIDS when one is critical regarding the decent } \\
\text { appearance of a partner? (no) }\end{array}$ & $\cdot 61.4$ & 47.3 \\
\hline scale ( 4 or more items right) & $\bullet 68.3$ & 45.9 \\
\hline \multicolumn{3}{|l|}{ Benefit of the protective effect of condom use } \\
\hline Does a condom protect against the AIDS virus? (yes) & 86.7 & 80.7 \\
\hline
\end{tabular}


(Table 10 continued)

\begin{tabular}{|c|c|c|}
\hline Is the use of condoms when visiting a prostitute a necessity? (yes) & 91.5 & 91.2 \\
\hline $\begin{array}{l}\text { Is everyone having different sexual partners not using a condom at risk of } \\
\text { AIDS? (yes) }\end{array}$ & 86.7 & 83.4 \\
\hline $\begin{array}{l}\text { Does the life partner run a risk of AIDS when someone commits adultery not } \\
\text { using a condom? (yes) }\end{array}$ & $\bullet 84.3$ & 76.0 \\
\hline Scale (all items right) & $\bullet 67.9$ & 57.4 \\
\hline \multicolumn{3}{|l|}{ Barrier of diminished satisfaction if using condoms } \\
\hline Making love using a condom is less satisfying (disagree) & 19.3 & 17.0 \\
\hline Making love using a condom is not genuine (disagree) & 39.1 & 33.9 \\
\hline Scale (score 4 to $6(2-6)$ ) & 57.2 & 53.2 \\
\hline Barrier of buying condoms & & \\
\hline I find it difficult to buy condoms (disagree) & 44.5 & 49.6 \\
\hline \multicolumn{3}{|l|}{ Self-efficacy condom use } \\
\hline I know exactly how to use a condom (agree) & 63.2 & 56.7 \\
\hline \multicolumn{3}{|l|}{ Intention condom use } \\
\hline I think I will use a condom in future if I have a new partner (agree) & 67.8 & 60.7 \\
\hline
\end{tabular}

- Chi-square test: pecos

When taking into account the background characteristics of the respondents and the level of groups in the multilevel logistic regression analysis, again an effect could be established on misunderstandings regarding $\mathrm{HIV}$ transmission $(\mathrm{OR}=5.9 .95 \%$ - $\mathrm{Cl}(2.3-$ 15.3) and risk appraisal for AIDS infection ( $\mathrm{OR}=2.9,95 \%$-CI (1.3-6.3)) (table 11). An interaction effect was found between group membership and formerly attendance at AIDS education. The effect on misunderstandings and risk appraisal was highest among men who had not participated earlier in AIDS education (ORs 8.7 and 3.8), however among men who had participated before, a significant effect could still be proven on misunderstandings regarding HIV transmission ( $\mathrm{OR}=3.5,95 \%$ - $\mathrm{CI}$ (1.29.9)). An effect on targets related to expectancies with respect to condom use was absent in the multilevel analyses without interaction terms, except for the effect on self-efficacy which was almost significant $(\mathrm{OR}=1.8,95 \%$-CI $(1.0-3.4))$. When interaction terms were added to the regression models, the AIDS education was shown to be significantly effective in several subcategories. In the older men, 30 years and above, the beliefs about the protective effect of condom use were more positive in the experimental group, compared to the control group. Moreover an effect was found on the barrier of diminished satisfaction of condom use among unmarried men, and on the self-efficacy of those who valued the peer AIDS education in the native language as important. An interaction effect was found between nationality and group mem- 
bership on the intention to use condoms in future with new partners. Moroccans who attended the AIDS education planned to use condoms more often than fellow Moroccans who did not yet follow the education session ( $O R=3.7)$. Among Turks, participants of the AIDS education were less likely to use condoms, than Turks who had not yet the opportunity to participate $(\mathrm{OR}=0.6)$. The education session failed to change the perceived barrier of buying condoms.

- Table 11. Effects of AIDS education on knowledge and determinants of condom use. Multilevel logistic regression analysis (Odds Ratios (ORs) and 95\%-confidence intervals $(95 \%-\mathrm{Cls}))$

\begin{tabular}{|c|c|c|c|}
\hline & OR & $95 \%-\mathrm{Cl}$ & $\sigma_{\text {group }}^{\prime}$ \\
\hline $\begin{array}{l}\text { Scale misunderstandings regarding HIV } \\
\text { transmission }\end{array}$ & .5 .9 & $(2.3-15.3)$ & $\cdot 1.89$ \\
\hline $\begin{array}{l}\text { AIDS education before } \\
\text { no AIDS education before }\end{array}$ & $\begin{array}{l}3.5 \\
8.7\end{array}$ & $\begin{array}{l}(1.2-9.9) \\
(3.1-23.9)\end{array}$ & $\cdot 1.79$ \\
\hline Scale risk appraisal for HIV infection & $\cdot 2.9$ & $(1.3-6.3)$ & $\cdot 1.18$ \\
\hline $\begin{array}{l}\text { AIDS education before } \\
\text { no AIDS education before }\end{array}$ & $\begin{array}{r}1.8 \\
-3.8\end{array}$ & $\begin{array}{l}(0.7-4.6) \\
(1.7-8.7)\end{array}$ & $\cdot 1.13$ \\
\hline $\begin{array}{l}\text { Scale benefit of the protective effect of } \\
\text { condom use }\end{array}$ & 1.6 & $(0.9-2.9)$ & $\cdot 0.47$ \\
\hline $\begin{array}{l}<30 \text { years } \\
\geq 30 \text { years }\end{array}$ & $\begin{array}{r}1.1 \\
\cdot 2.6\end{array}$ & $\begin{array}{l}(0.6-2.2) \\
(1.2-5.7)\end{array}$ & $\cdot 0.46$ \\
\hline $\begin{array}{l}\text { Scale barrier of diminished satisfaction } \\
\text { if using condoms }\end{array}$ & 1.0 & $(0.7-1.6)$ & 0.08 \\
\hline $\begin{array}{l}\text { married } \\
\text { unmarried }\end{array}$ & $\begin{array}{r}0.7 \\
\cdot 2.0\end{array}$ & $\begin{array}{l}(0.4-1.1) \\
(1.1-3.7)\end{array}$ & 0.06 \\
\hline Barrier of buying condoms & 0.8 & $(0.5 \cdot 1.3)$ & 0.31 \\
\hline Self-efficacy condom use & 1.8 & $(1.0-3.4)$ & ${ }^{\circ} 0.58$ \\
\hline $\begin{array}{l}\text { education in native language } \\
\text { important } \\
\text { education in native language } \\
\text { unimbortant }\end{array}$ & $\cdot 2.4$ & $(1.2-4.8)$ & $\cdot 0.56$ \\
\hline Intention condom use & 1.2 & $(0.6-2.6)$ & \urcorner .09 \\
\hline $\begin{array}{l}\text { Turks } \\
\text { Moroccans }\end{array}$ & $\begin{array}{r}0.6 \\
\cdot 3.7\end{array}$ & $\begin{array}{l}(0.2-1.5) \\
(1.2-11.6)\end{array}$ & $\cdot 0.90$ \\
\hline
\end{tabular}

$\sigma_{\text {growp }}=$ group specific variation (standard errors)

- significant $(p<0.05)$, confidence interval does not comprise value 1 
Extra-binomial variation was absent in all multilevel logistic regression analyses. Therefore this variation was restricted to 1 in all models. The variation at group level, when only first level variables were entered in the models was, in most cases, significant, except for the barriers of diminished satisfaction and the buying of condoms (table 11). These latter outcome measures seemed to be explained by the characteristics of the individuals. When the second level variables, that is type of locality, estimated mean age and level of conservatism, were added to the multilevel logistic regression models, only an effect on the perceived benefit of the protective effect of condoms could be established. The variation between groups decreased from 0.46 to 0.08 and was not longer significant. The group characteristics type of locality and level of conservatism explained to a great extent the variation in beliefs about condom prevention. The beliefs were more positive in mosques and moderately conservative audiences, and less positive among conservative audiences. The nationality of the respondents was treated as a first level variable in the logistic regression models, though it could be viewed as a group characteristic. Turks and Moroccans differed significantly with respect to beliefs about the protective effect of condom use and self-efficacy toward condom use. More Moroccans than Turks had beliefs in the desired direction.

\subsection{Conclusion and discussion}

AIDS education for immigrants in the Netherlands, given in the native language by peers, was evaluated. Turkish and Moroccan men were trained to educate people from their own ethnic group. The aim of this peer AIDS education was to increase knowledge about transmission and prevention of AIDS, to reduce unnecessary fears and misunderstandings and to change people's behaviour toward condom use. The effect of peer education on the perceived threat of AIDS and beliefs about condom use was studied. The study design proved to be useful in the difficult setting of coffee-houses, mosques and bars, that are visited by men who are seldom asked to cooperate in a research project. The response to the questionnaire was satisfactory, however poorly educated immigrants were underrepresented.

The AIDS education primarily had an effect on the perceived threat of AIDS. Misunderstandings with respect to the transmission of HIV were cleared up and the risk appraisal for HIV infection had improved. The effect was highest in men who had not received AIDS education before. The believe that condom use is beneficial to AIDS prevention was already widespread among the Turkish and Moroccan men. An educational effect was only achieved in the older age group. The positive feelings toward using condoms among the unmarried, who probably run a higher risk of HIV infection because of multiple sexual partners, is a hopeful outcome of the AIDS education. The effect on self-efficacy shows that a positive attitude toward peer education is a requirement for a productive result. About 65 to $70 \%$ of the audience thought it important to have education on AIDS in the native language by a peer. The presence of an effect on intention to use condoms among Moroccans, and its absence among Turks is remarkable. A closer study into the activities of the education sessions, using registration forms, showed that less attention was paid to the demonstration of con- 
dom use during the Turkish sessions than the Moroccan, which may indicate that talking about condoms is less accepted among Turks. This could be an explanation for the lack of effect on intention to use condoms in Turks.

The variation between groups in the multilevel logistic regression analyses in most cases was significant and high, which means that differences in the experimental and control group could be explained by group characteristics. These characteristics are unclear in most models. An effect of nationality, the type of locality, that is coffeehouse, mosque or otherwise, and the degree of conservative or modern ideas among the audience, could only be demonstrated with respect to beliefs about the protective effect of condom use. Moreover an association was found between nationality and self-efficacy.

The AIDS education was started to bridge the gap between the general mass-media campaigns and the language problems of immigrant groups in the Netherlands. Considering the clearance of misunderstandings and the change of the appraisal of susceptibility to AIDS, the peer education is seen as an appropriate alternative. In spite of these effects, some instruction is still necessary on the incubation time of HIV and the policy of testing of prostitutes. The behaviour change of getting all subgroups to use condoms remains a difficult task. The AIDS education of customers of coffeehouses and visitors of mosques of one hour duration may have been too general and too brief, to affect the complex mechanism of behaviour change. A discussion of sexual contacts with different partners, extramarital contacts, and condom use turned out to be difficult in the muslim culture of Turks and Moroccans. Research into the stages of change is recommended to realize behaviour change in all target groups. The message of the peer educator has to be adapted to the people's needs. From the transtheoretical model of change it becomes clear that stressing the benefits of condom use is relevant in the precontemplation and contemplation stage, when the subjective perception of cons related to condom use outweigh the pros. When people are ready to adopt and maintain a behaviour, the action is strongly related to self-efficacy. Promoting people's confidence in skills at that moment is very relevant. ${ }^{21}$ For example, young immigrants who experiment with sexual contacts or unmarried immigrants who have different sexual partners may be open to the message of condom use. Strategies should be developed to change their beliefs and self-efficacy. For the audience which is not yet ready to consider condom use, successful communication attracting attention and improving comprehension of HIV transmission and preventive methods is recommended..$^{2,23}$

This evaluation study makes clear that continuation of peer education in the native language is to be recommended. Continuous and careful discussion within migrant groups on condom use to break the taboo in their cultures is relevant. An effect on misunderstandings could still be proven in people who had previously attended AIDS education sessions, which proves the necessity to repeat the message of AIDS prevention in immigrant groups. 


\section{References}

1. Coates TJ, Collins C. Preventing HIV infection. Altering behavior is still the primary way to control the epidemic, Scientific American 1998;279(1):76-77.

2. Hooykaas C, Van der Velde FW, Van der Linden MMD, Van Doornum GIJ, Coutinho RA. The importance of ethnicity as a risk factor for STDs and sexual behaviour among heterosexuals. Genitourin Med 1991:67:378-83.

3. Laar MJW van de, Sleutjes MPM, Postema, CA, Water HPA van de. Sexueel overdraagbare aandoeningen bij allochtone bevolkingsgroepen; een oriēnterend onderzoek. Ned Tijdschr Geneesk 1991;135:1542-1547.

4. Hoek van den JAR, Coutinho RA. Seksueel overdraagbare aandoeningen, HIV en AIDS bij migranten. Ned Tijdschr Geneesk 1994;138:2188-92.

5. Everaert HA, Lamur HE. Alles wat geheim is, is lekker; seksuele relaties en beschermingsgedrag van Turkse mannen. Amsterdam: Het Spinhuis, 1993.

6. Gelder P, Lamur HE. Tussen schaamte en mannelijkheid; seksuele relaties en beschermingsgedrag onder Marokkaanse mannen. Amsterdam: Het Spinhuis, 1993.

7. Brugman E, Vogels T, Van Zessen G. Trends in sexual risk behaviour among Turkish/Moroccan adolescents in the Netherlands 1990-1995. Eur J Public Hlth 1997;7:418-20.

8. Pulley L, McAllister AL, Kay LS, O'Reilly K. Prevention campaigns for hard-to-reach populations at risk for HIV infection: theory and implementation. Health Educ Quarterl 1996;23:488-96.

9. Eng E, Parker E, Harlan C. Lay health advisor intervention strategies: a continuum from natural helping to paraprofessional helping. Health Educ \& Behav 1997;24:413-7.

10. Rogers E. Diffusion of innovations. New York: Free Press, 1983.

11. Bandura A. Social foundations of thought and action: a social cognitive theory. Englewood Cliffs, N.J.: Prentice Hall, 1986.

12. Van de Ven AH, Delbecq AL. The nominal group as a research instrument for exploratory health studies. Am J Public Health 1972;62:337-42.

13. Green LW, Kreuter MW. Health promotion planning; an educational and environmental approach. Mountain View: Mayfield, 1991.

14. Rosenstock IM, Strecher V], Becker MH. The health belief model and HIV risk behavior change. DiClemente RJ, Peterson JL (ed). Preventing AIDS: theories and methods of behavioral interventions. New York: Plenum Press, 1994.

15. Janz NK, Becker MH. The health belief model: a decade later. Health Educ Quarterl 1984;11:147.

16. Nutbeam D, Harris E. Theory in a nutshell: a practioner's guide to commonly used theories and models in health promotion. Sydney: National Centre for Health Promotion, 1998.

17. Bandura A. Social cognitive theory and exercise of control over HIV infection. DiClemente RJ. Peterson JL. Preventing AIDS. Theories and methods of behavioral interventions. New York: Plenum Press, 1994, 25-59.

18. Goldstein H. Multilevel statistical models, 2nd edition. London: Kendall's Library of Statistics, 1995 .

19. Hox IJ. Applied multilevel analysis, 2nd edition. Amsterdam: TT publications, 1995.

20. Rasbach J. Woodhouse G. MLn command reference. Multilevel Models Project. London: Institute of Education University of London, 1996. 
21. Grimley DM, Prochaska GE, Prochaska JO. Condom use adoption and continuation: a transtheoretical approach. Health Educ Res 1997:12:61-75.

22. Fisher JD, Fisher WA, Williams SS, Malloy TE. Empirical tests of an information-motivation-behavioural skills model of AIDS-preventive behaviour with gay men and heterosexual university students. Health Psychology 1994;13:238-50.

23. McGuire LW. Attitudes and attitude change. Linsey G, Aronson E. The handbook of social psychology vol, 2, New York: Academic Press, 1964. 


\section{Older adults}


2thybs voblo 


\section{Chapter 5}

Psycho-social problems in the Rotterdam elderly and prevention options

epidemiological diagnosis

intervention development

effect evaluation 


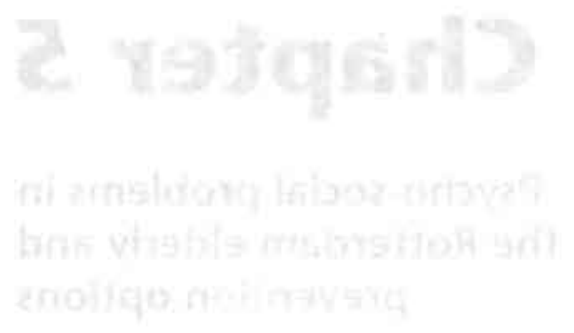

\section{Abstract}

The aim of this study was to examine the occurrence of psycho-social problems among the elderly in order to plan prevention programs. A questionnaire was sent in 1990 to a sample of 1989 inhabitants of the city of Rotterdam aged $65-79$ years living on their own, drawn at random from the municipal registrar's office (response $58 \%$ ). The results showed that one third of the respondents experienced psycho-social problems. Groups at risk were women, men who lived alone, those with a low socio-economic status, and people who lived in apartment buildings. These socio-demographic variables explained only $5 \%$ of the variance in psycho-social wellbeing. Risk indicators for psycho-social problems were problems in the performance of activities of daily living (ADL) and household activities (HHA) as well as decreased social support. The relationship between satisfaction with living conditions and psycho-social problems was affected by these risk indicators. Elderly people who experienced only psycho-social problems and elderly people who faced only ADL/ HHA-problems visited their general practitioner (GP) equally during the three months before the survey. Elderly people who experienced both psycho-social and ADL/HHA-problems visited their GP most frequently. The elderly in Rotterdam seemed more frequently to have psycho-social problems, compared to elderly people in other Dutch cities and to norm scores. 


\section{Psycho-social problems in the Rotterdam elderly and prevention options}

\subsection{Introduction}

Loss experiences mark the dawn of life for elderly people. Their retirement has consequences for their social and financial position. They are faced with the loss of a life partner or friends. It is even argued that elderly people live on the margin of society. They are excluded from a society in which people are valued for their job position, they have a lower education level than younger age groups and they suffer from a poor housing situation. ${ }^{1}$ These experiences may affect the psycho-social health of elderly people.

Knowledge of risk groups that may be susceptible to psycho-social problems is needed to designate target groups for prevention. Moreover, knowledge of risk indicators facilitates the development of prevention activities and health care policy. Risk indicators are defined as variables predictive for the occurrence of psycho-social problems. ${ }^{2}$ Three principal categories of risk indicators at the level of individuals and their environment (micro level) are distinguished, i.e. stressful circumstances and life events, perceived lack of social support, and personality traits. ${ }^{3}$ Moreover, a distinction is made in the literature between risk indicators at the meso level, i.e. the level of neighbourhoods, municipalities, organizations, and the macro level, i.e. societal structures. ${ }^{4}$ The following risk indicators have been shown in the literature to be associated with psycho-social health. Elderly people who have problems with performing activities of daily life (ADL) or household activities (HHA) experience more psycho-social problems, than older people without ADL or HHA impairments. ${ }^{5}$ Another study shows that people's subjective evaluation of their social network is, besides physical health, a predictor of well-being. ${ }^{6}$ Moreover, it appeared from a review study about the influence of living accommodation and environment on health, that people's living conditions are among other factors important to wellbeing. ${ }^{7}$

A study into the prevalence of psycho-social problems among the Rotterdam elderly and the association with background characteristics and risk indicators is described in this article. ${ }^{8}$ The aim of the study was to contribute to health promotion and health care policy. The following research questions were addressed. What is the prevalence of psycho-social problems in elderly Rotterdam citizens living independently? Which groups are at risk regarding psycho-social problems? What are risk indicators of psycho-social problems? What is the association between psycho-social health and the use of services? The following risk indicators were studied, ADL and HHA impairments, perceived social support and satisfaction with living conditions. 


\subsection{Method}

\subsubsection{Study sample}

A postal questionnaire was sent to a sample of 1989 independent living elderly inhabitants of the city of Rotterdam aged 65 to 79 years, in spring 1990 . The sample amounted to $3 \%$ of the elderly population and included elderly people living in service apartment buildings. Citizens without Dutch nationality, except for Surinam and Antillian elderly, were excluded because of insufficient mastery of the Dutch language. The age limit of 79 years was used, because of an expected high non response to the questionnaire in the oldest age group.

\subsubsection{Questionnaire}

The following topics were included in the questionnaire.

Psycho-social problems: the respondents' psycho-social wellbeing was assessed using the Dutch scale 'Schaal Subjectief Welbevinden Ouderen' (SSWO, Scale Subjective Wellbeing Elderly). ${ }^{9}$ The scale consists of 30 items, forming five subscales, i.e. health, self-respect, morale, optimism and contacts. The range of the scores of the SSWO and the subscales varies from 0 to 20 . Norm scores are available indicating low, moderate and high wellbeing. ${ }^{9} \mathrm{~A}$ score of 12 or lower in males and a score of 10 or lower in females is defined as low wellbeing. The score range 19-20 in males and 18-20 in females is defined as high wellbeing. Differences between males and females cannot be found if using these different cut-off points, however the norm scores are used in this article to enable comparison with studies into the wellbeing of elderly people of other cities. Moreover, mean SSWO scores are given in this article.

Background characteristics: the following socio-demographic variables were included, gender, age, living situation i.e. living alone or together with a partner or others, living in service apartments or not, and socio-economic status i.e. last occupation.

Risk indicators: a list of activities of daily living (ADL, 5 items) and household activities (HHA, 5 items) was included. The respondents were asked whether they could perform the activities without help. ADL/HHA impairments were present if the respondents had problems with one or more ADL or HHA activities.

The amount of social support obtained from the person designated by the respondent as the most important, was assessed using a 10 items scale. ${ }^{10}$ Social emotional support is defined as positive aspects of personal relationships, like sharing of emotions, getting advise and practical help. " A score of 4 or less on the social support scale, range 0 to 10 , was viewed as little social support.

Two questions about satisfaction with housing accommodation and the living environment e.g. services in the neighbourhood, liveliness of the neighbourhood and 
contact with neighbours, were included. Dissatisfaction with housing accommodation or living environment or both was defined as dissatisfaction with living conditions.

Use of services: i.e. contact with the general practitioner (GP), contact with a psychiatrist or Regional Institute of Ambulatory Mental Health Care (RIAMHC) and participation in leisure activities over a time span of three months were requested.

\subsubsection{Analysis}

The association between psycho-social health at the one side and background characteristics, risk indicators and use of services at the other, was established. The SSWO, measuring psycho-social health, was viewed as a discrete variable and mean scores were assessed when defining risk groups and indicators. The significance of the association was tested using statistical tests of variance. Interaction and confounding was studied, using multiple regression analysis. The prevalence of psycho-social problems and its association with use of services was studied, using SSWO norm scores.

\subsection{Results}

\subsubsection{Response}

The response to the questionnaire was $58 \%$. This result can be viewed as satisfying. considering the nature of the questions about psycho-social problems and social contacts. Elderly people experiencing psycho-social problems probably more often failed to respond, however this could not be verified. A comparison was made between the response group and the total Rotterdam population aged 65 to 79 years, with respect to gender, age and marital status. Unmarried elderly men, aged 75 to 79 years, were slightly underrepresented ( $69 \%$ against $73 \%$ in the population), however in general the response was representative regarding the background characteristics. The partial response to the SSWO was $52 \%$. This response group was similar to the total response group of the questionnaire, with respect to gender, age and marital status.

\subsubsection{Prevalence}

The prevalence of low wellbeing was $32 \%$ among male respondents, $58 \%$ experienced moderate wellbeing and $10 \%$ high wellbeing. The prevalences among female respondents were $31 \%, 56 \%$ and $13 \%$ respectively. The amount of respondents that experienced psycho-social problems was higher in the female response group than among males, if the norm scores for males were applied to females. The prevalence of low wellbeing in that case was $44 \%$ among females, moderate wellbeing $50 \%$ and high wellbeing $6 \%$. The mean score on the SSWO for men and women taken together was 13.3 (standard deviation 4.1). 


\subsubsection{Risk groups}

All background characteristics except age were correlated significantly to psycho-social health (table 12). The mean SSWO score in women was lower than in men. Respondents living alone experienced lower wellbeing than people living with a partner or others. The psycho-social health among respondents living in service apartments was poorer than among independent living elderly. The lower socio-economic groups also experienced more psycho-social problems compared to the higher socio-economic groups.

- Table 12. Mean SSWO scores per socio-demographic variable or risk-indicator

\begin{tabular}{|c|c|c|c|}
\hline & mean & standarddeviation & $n$ \\
\hline \multicolumn{4}{|l|}{ Gender } \\
\hline male* & 14.1 & 3.9 & 416 \\
\hline fernale & 12.7 & 4.2 & 619 \\
\hline \multicolumn{4}{|l|}{ Living situation } \\
\hline single* & 12.4 & 4.4 & 362 \\
\hline with partner or others & 13.8 & 3.9 & 663 \\
\hline \multicolumn{4}{|l|}{ Service apartment } \\
\hline no, independent living* & 13.4 & 4.1 & 944 \\
\hline yes & 12.1 & 4.3 & 77 \\
\hline \multicolumn{4}{|l|}{ Age } \\
\hline $65-69$ & 13.3 & 4.2 & 436 \\
\hline $70-74$ & 13.6 & 4.1 & 335 \\
\hline $75-79$ & 12.8 & 4.0 & 264 \\
\hline \multicolumn{4}{|l|}{ Occupational level } \\
\hline no job* & 13.1 & 4.2 & 120 \\
\hline unskilled labour & 12.1 & 4.5 & 187 \\
\hline skilled labour & 13.4 & 4.0 & 170 \\
\hline lower employee & 13.1 & 3.8 & 240 \\
\hline self-employed & 14.1 & 3.9 & 49 \\
\hline secondary employee & 14.5 & 3.7 & 101 \\
\hline higher employee & 15.6 & 3.7 & so \\
\hline \multicolumn{4}{|l|}{ ADL/HHA impairments } \\
\hline difficulty with adl or hha* & 11.2 & 4.1 & 338 \\
\hline no difficulty with adl or hha & 14.3 & 3.7 & 673 \\
\hline \multicolumn{4}{|l|}{ Perceived social support } \\
\hline little & 11.7 & 4.2 & 207 \\
\hline moderate to much & 13.8 & 4.0 & 753 \\
\hline \multicolumn{4}{|l|}{ Satisfied with living conditions } \\
\hline no* & 11.5 & 4.2 & 222 \\
\hline yes & 13.8 & 4.0 & 792 \\
\hline
\end{tabular}

- t-test/F-test two sided $\mathrm{p}<0.05$ 
Confounding and interaction effects of the background characteristics on psychosocial health were studied using multiple regression analysis. Interaction was found between gender and living situation (living alone or together). The interaction term added significantly to the regression model including psycho-social health as dependent variables and all background characteristics, except age, as independent variables $\left(\mathrm{F}_{1,901}=5.55, \mathrm{p}<0.05\right)$. The explained variance was $5 \%$ only. The mean SSWO score among women living alone was 12.4 and approximated the mean score of 13.0 among women living with a partner or others. The SWWE score of men living alone equalled that of single women, however considering the higher scores among men in general, single men are a risk group for psycho-social problems. Men living together with a partner or with other people experienced on average few psycho-social problems (mean SSWO score of 14.5). A confounding effect on the association between psycho-social health and a background characteristic could not be proven, meaning that the other background characteristics did not change the association.

Women, living alone or not, were in summary, a risk group for psycho-social problems, and among males those living alone were at risk. Moreover elderly people from lower socio-economic groups and older people living in service apartments were risk groups considering the significant association with psycho-social health.

\subsubsection{Risk indicators}

The risk indicators ADL/HHA impairments, perceived social support and satisfaction with living conditions were related significantly to psycho-social health. The elderly respondents who experienced ADL/HHA-impairments had poorer psychosocial health (table 12). The prevalence of problems with the performance of one or more activities of daily living (ADL) is $9 \%$ and of one or more household activities (HHA) is $31 \%$. Respondents who experienced little social support from the person valued as the most important (prevalence $22 \%$ ) had more psycho-social problems than those who experienced moderate or much social support. The psycho-social health of respondents who were not satisfied with their housing accommodation or living environment (prevalence $23 \%$ ) was poorer, compared to respondents who were happy with their living environment.

Interaction between these risk-indicators was not found, however ADL/HDL impairments and social support confounded the association between psycho-social health and satisfaction with living conditions. The difference in mean SSWO scores between elderly respondents who were satisfied and not satisfied was 2.1, using a multiple regression model including only satisfaction with conditions as independent variable. The difference was 1.6, when ADL/HDL impairments and social support were added to the model (table 13). The mean SSWO score changed especially among respondents who were not satisfied, however change was limited (from 11.7 to 12.1).

Risk indicators for psycho-social health were in summary, ADL/HHA impairments and social support. These risk indicators were confounders for the association between psycho-social health and satisfaction with living conditions. 
- Table 13. B-coefficients of multiple regression models with psycho-social health as outcome variable

\begin{tabular}{|lrr|}
\hline & $B$ & standard error \\
\hline $\begin{array}{l}\text { Bivariate model* } \\
\text { satisfaction with living conditions } \\
\text { constant }\end{array}$ & 2.14 & 0.32 \\
& 11.72 & 0.28 \\
Multivariate modelf & & \\
satisfaction with living conditions & 1.60 & 0.30 \\
social support & 1.72 & 0.30 \\
ADL/HHA-impairments & 2.73 & 0.26 \\
constant & 8.96 & 0.37 \\
\hline
\end{tabular}

- $F_{1,921}=44.64, p<0.05, R^{2}=0.05$

\# $F_{1,919}=64.32, p<0.05, R^{2}=0.17$

\subsubsection{Use of services}

The use of services of respondents experiencing ADL/HDL impairments, psychosocial problems, or a combination of these variables is shown in table 14. The health problems that are distinguished do not need to be the reason for the use of the particular service. The proportion of respondents that had contact with their GP was highest among those experiencing both ADL/HHA and psycho-social problems $(87 \%)$. The equal use of general practitioners by elderly respondents experiencing only psycho-social problems or ADL/HHA impairments is remarkable (table 14). Use of mental health care (RIAMHC or psychiatrist) was highest among respondents who experienced psycho-social problems, compared to respondents who experienced HDL./HHA impairments exclusively, however use of mental health care is low in all categories. An association between types of health problems and use of leisure activities is lacking.

- Table 14. Use of services during the last three months within categories of health problems

\begin{tabular}{|lrrrr|}
\hline & $\begin{array}{r}\text { no } \\
\text { problems } \\
(n=438)\end{array}$ & $\begin{array}{r}\text { ADL/HHA- } \\
\text { impair- } \\
\text { ments } \\
(n=107)\end{array}$ & $\begin{array}{r}\text { psycho- } \\
\text { social } \\
\text { problems } \\
(n=235)\end{array}$ & $\begin{array}{r}\text { both } \\
\text { categories } \\
(n=231)\end{array}$ \\
\hline $\begin{array}{l}\text { General practitioner* } \\
\text { RIAMHC/psychiatrist* } \\
\text { Leisure activities: club, dance, bingo etc. }\end{array}$ & $\%$ & $\%$ & 96 & $\%$ \\
\hline
\end{tabular}

- Chi-square test $p<0.05$ 


\subsection{Discussion}

An important part of the Rotterdam elderly population experienced psycho-social problems. The prevalence of psycho-social problems measured using the Scale Subjective Wellbeing Elderly (SSWO) amounted approximately to one third of the independent living population aged 65 to 79 years. The prevalences of low wellbeing were higher in both men and women than the SSWO norms, which were delineated from a study in the population of the Dutch city of Groningen ( $32 \%$ in men against the norm of $22 \%$, and $31 \%$ against $21 \%$ in women).$^{9}$ The respondents of our study experienced more often a high wellbeing; a prevalence of $10 \%$ in men against the norm of $8 \%$, and $13 \%$ against $9 \%$ in women. A difference in age between the Groningen study population, 56 to 85 years, and our study population 65 to 79 years, may explain the difference in prevalences found, however unfavourable psycho-social health remains when our study is compared to studies which used the SSWO in the Dutch cities of Eindhoven, study population aged 65 to 75 years, and Venlo, study population 65 years and over. ${ }^{12.13}$ These results are an indication for a poorer psychosocial health of the Rotterdam population, compared to other cities in the Netherlands, however the influence of a difference in characteristics of the study populations has to be investigated.

The following risk groups for psycho-social problems were found; women (living alone or with a partner or others), men living alone, elderly people from lower socio-economic groups, and people living in service apartments. A difference between male and female older people could not be found using the SSWO norm scores, however the norm scores are less suitable to indicate risk groups. If equal norms are applied for men and women, or mean scores are used, than the psycho-social health of women and men (living with a partner or others) differed.

A significant association between psycho-social health and age was absent, however the age range of the study population 65 to 79 years was limited. The psycho-social health of the oldest old was unknown in our study. Other studies reported a weak or absent association between age and psycho-social problems, also for loneliness, ${ }^{9,14,15}$ Other factors, e.g. living situation or socio-economic status will be more important to psycho-social health. Elderly people living in old people's homes were missed in this study. Another study showed a higher prevalence of psycho-social problems among these elderly residents, compared to independent living elderly people. ${ }^{12}$

The before mentioned risk groups are target groups for prevention programs or health care policy. The program or policy goals, size of risk groups and their openness to behavioural change will determine in practice what target groups will be selected.

Options for preventive activities can be concluded from the association between psycho-social health at the one side and $\mathrm{ADL} / \mathrm{HHA}$-impairments and perceived social support at the other, however other risk indicators that had not been studied like personality traits have to be taken into account. The onset of ADL/HHA impairments 
can be prevented using programs that promote healthy lifestyles. Moreover, secondary and tertiary prevention of the progress and consequences of physical invalidity is relevant, e.g. promotion of the availability of public transport, volunteer shopping services and volunteer handymen. Prevention activities in the field of social support are aimed at the size and characteristics of the social network of individuals. An example of the change in the quantity of social contacts is promotion of participation in leisure activities and meeting facilities. Participation in support groups will have an effect on the perception of current social contacts. ${ }^{16}$ Interventions in the field of living conditions of elderly people, may be targeted at experienced ADL/HHA impairments and lack of social support, considering their confounding effect on the association between psycho-social health and satisfaction with housing accommodation and living environment. The before mentioned activities that promote healthy lifestyles and change of the size and perception of social contacts may have a beneficial effect on satisfaction with living conditions.

Institutions that are active in different fields, among which social work, mental health care and environmental planning, can contribute to the above given activities to prevent or diminish psycho-social problems and enable people to cope. These institutions should offer assistance in close collaboration. Many elderly respondents with psychosocial problems had called in the help of their GP. The GP can play a central role in screening of psycho-social problems in elderly people and referring them to other professionals, although the latter also have to play their role in observing psychological problems.

Experience and evaluation studies will point out whether prevention activities in the field of the risk indicators $\mathrm{ADL} / \mathrm{HHA}$ impairments and social support, aimed at the risk groups determined in this study, contribute to the prevention of psycho-social problems in the elderly population. 


\section{References}

1. Knipscheer CPM. Oud worden als maatschappelijk verschijnsel. In: Schouten J, Leering C, Bender J (red), Leerboek geriatrie. Utrecht: Bohn Scheltema en Holkema, 1985, 30-46.

2. Hosman CMH. Psychosociale problematiek en hulpzoeken; een sociaal-epidemiologiese studie ten behoeve van preventieve geestelijke gezondheidszorg. Lisse: Swetz \& Zeitlinger, 1983.

3. Ridder D de. Determinanten van psychische gezondheid; een verkenning van de literatuur. Utrecht: Nederlands Centrum Geestelijke Volksgezondheid, 1988.

4. Bosma MWM, Hosman CMH. Preventie op waarde geschat; een studie naar de benvloedbaarheid van determinanten van psychische gezondheid. Nijmegen: Bêta-boeken, 1990.

5. Linschoten CP van, Heuvel WJA van den, Patronen van behoeften bij ouderen. Tijdschrift voor Sociale Gezondheidszorg 1989; 67:411-415.

6. Deimling GT, Harel Z. Social integration and mental health of the aged, Research on aging 1984; 6: 515-527.

7. Bogaard, JHM van den. Woonsituatie en gezondheidsbeleving; overzichtsstudie; determinanten van gezondheid. Rotterdam: GGD Rotterdam e.o., GVO-rapport 113, 1990.

8. Kocken PL. Psychische welbevinden op oudere leeftijd; onderzoek naar de prevalentie van psychische problematiek en preventiemogelijkheden bij Rotterdamse ouderen. Rotterdam: Afdeling Epidemiologie en afdeling OGGZ, GGD Rotterdam e.o., rapportnummer 91, 1991.

9. Tempelman CII. Welbevinden bij ouderen; constructie van een meetinstrument. Groningen: Rijksuniversiteit Groningen, Proefschrift, 1987.

10. Tilburg $T$ van. Verkregen en gewenste ondersteuning in het licht van eenzaamheidservaringen. Utrecht: Elinkwijk, Proefschrift, 1988.

11. Tilburg $T$ van, Sociaal-emotionele ondersteuning, een vergelijking van twee meetinstrumenten. Mens en Maatschappij 1987; 62: 5-16.

12. Bosma A. De gezondheid van mensen in de derde levensfase; een onderzoek naar lichamelijke en psychische aspecten. Eindhoven: GGD Eindhoven, 1988.

13. Klerk MMY de, Huijsman R. Evaluatie totaal ouderenbeleid Venlo, deel 2a: leefsituatie en voorzieningengebruik van zelfstandig wonende ouderen in de gemeente Venlo. Maastricht: Rijksuniversiteit Limburg, vakgroep Economie van de Gezondheidszorg, 1989.

14. Jong-Gierveld J de, Kamphuis F, Dykstra P. Old and lonely? Compr Gerontol B 1987; 1: 13-17.

15. Baecke JAH, Boer E de, Harten C e.a. Ouderen in s-Hertogenbosch nu en in 2000: onderzoeksresultaten. 's-Hertogenbosch: Gezondheidsdienst (GGD) Stadsgewest 's-Hertogenbosch, 1990.

16. Linneman M, Leene G, Bettink K e.a. Uit eenzaamheid; over hulpverlening bij ouderen. Houten: Bohn Stafleu Van Loghum, 1990. 


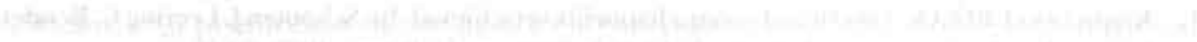

If

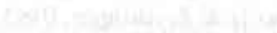

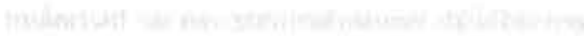

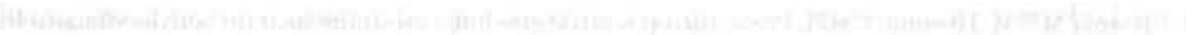

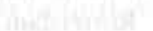

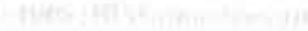




\section{Chapter 6}

A loneliness intervention program aimed at older adults and intermediates:

linkage of program plans and users' needs

epidemiological diagnosis intervention development effect evaluation 


\section{d vigush}

Abstract

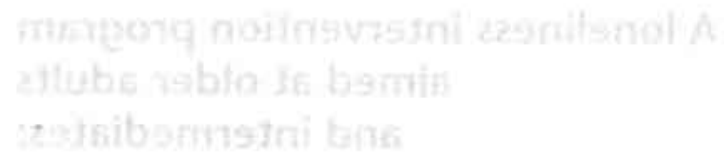

Intermediates' satisfaction with linkage of program plans and users' needs in the Dutch loneliness intervention program In Good Company (IGC) was studied. The intermediates were volunteers and professional workers in the field of health care and social welfare. The program targets of IGC were prevention and diminishment of loneliness in older people, aged 55 years and over, and improvement of helping and cooperation skills of intermediates. Experiments with different linkage approaches were carried out successively in three neighbourhoods. In the first neighbourhood an instrumental linkage strategy was used and local organizations were asked to carry out a predesigned program. In the other two neighbourhoods involvement of the intermediates in program design increased, using bottom up, democratic linkage strategies. The intermediates' satisfaction was measured using postal questionnaires, sent about 20 months after the introduction of the program to the three neighbourhoods. Satisfaction was highest in the neighbourhood where the intermediates were consulted most explicitly and they had a clear voice in the design and organisation of the intervention, using democratic linkage strategies. The needs assessments among older adults and intermediates showed that there was a demand for change of environmental determinants using meeting and recreational activities for older adults, instead of the behaviour oriented support groups and skills courses which had been proven efficacious from research. It is concluded that the use of democratic linkage strategies, like needs assessments, local action plans and two way communication between program designers and users, is essential for successful dissemination of health promotion activities. 


\section{A loneliness intervention program aimed at older adults and intermediates}

\subsection{Introduction}

An important fallacy in health promotion is the top down introduction of programs after they have been proven efficacious in an isolated experimental evaluation design. ${ }^{1,2}$ The communication endeavours with the program users only start, when the opportunity to adapt the program to the users' needs has passed over. It can be seen from health promotion planning literature that a successful dissemination is dependent on the involvement of the target population from the very beginning. ${ }^{35}$ The program users should be actively involved in determining what problems are present in the community and contribute to the definition of priorities for action. This so called social diagnosis is the point of departure for community participation in community health promotion programs. A true two-way process between program designers and users in a linkage system is defended in literature. ${ }^{68}$ In such a linkage system the interests of the resource system (program designers) and user systems (program users) are connected. Examples of a linkage system are local work groups, community hearings and training of key figures from the community. ${ }^{89,3}$ The top down approach, when the influence of program users on the design is little, is designated in this article as the instrumental linkage strategy. ${ }^{10}$ This approach fits the concept of planning as rationally applying scientific knowledge and hierarchical decision making. ${ }^{11.12} \mathrm{~A}$ central actor decides, on a scientific basis, which interventions meet the goals of a program and determines how they will be implemented. The bottom up approach, when program users share in the decision making on what intervention suits their needs, how the intervention will be communicated to the public and how the evaluation takes place, is called democratic use of linkage systems.

The importance of having program users involved in the program development has been scarcely tested empirically. ${ }^{8}$ In this article the influence of linkage of program designers' ideas and users' needs on the users' satisfaction is described. The Dutch Ioneliness intervention program, called In Good Company, was studied. The program was active in three neighbourhoods successively and the linkage approach in every neighbourhood was different, varying from use of instrumental to democratic strategies. These strategies were chosen on the base of experiences with the program, when the program moved from one neighbourhood to another. The satisfaction of the intermediate users, i.e. volunteers and professional workers, who had to organize the preventive activities, is described. The following research questions are addressed. What was the linkage approach used in the In Good Company program carried out in three experimental Rotterdam neighbourhoods? What linkage approach enhanced the satisfaction of the intermediates with the program and contributed to successful dissemination? 


\subsection{Methods}

\subsubsection{The In Good Company program}

People's social bonds are important to their health. Longitudinal research shows that older people with limited social networks and low availability of social support have higher mortality rates and an increased risk of mental health problems. ${ }^{13-16}$ The subjective evaluation of the size of social networks and amount of support received determine whether someone feels lonely or not. ${ }^{17}$ Research in the Netherlands shows that about 10 to $15 \%$ of the elderly population experiences severe feelings of loneliness. ${ }^{18}$ Institutions in the field of (mental) health care, home care, social welfare and voluntary work in the city of Rotterdam, the Netherlands, became aware of the magnitude of loneliness among older adults in the city, and in 1992 they started the prevention program 'In Good Company' (IGC) to prevent and diminish loneliness in the population of Rotterdam aged 55 and over. All older adults of the three experimental neighbourhoods, whether they were lonely or not, belonged to the target population. Moreover the program was aimed at the intermediates to improve their skills in helping lonely older people and to ameliorate the cooperation between intermediates or institutions. The planning of the IGC program took place in a complicated setting at city and local level in which many actors with different responsibilities were active. At city level a work group of experts in the field of health care and social welfare took care of the progress of the program. At local level intermediate organizations of professionals and volunteers in three neighbourhoods of Rotterdam, were responsible for the actual development and performance of the program interventions. A project leader facilitated the exchange of ideas between city and local level. Moreover he gave support to the process of cooperation between the local organizations in realizing the program.

\subsubsection{Program activities}

The IGC program included both behaviour and environment oriented activities. Loneliness is the result of a complex process in which multiple factors are important. Behavioural characteristics of individuals, i.e. internal causes, and causes in the environment, beyond the control of an individual, i.e. external causes, are important for a person's appraisal of social support and behaviour concerning the social network. ${ }^{19}$ Internal causes are, for instance, low self-esteem or lack of social skills. ${ }^{2024}$ Preventive interventions that can influence these internal factors are support groups, social skills training and counselling. ${ }^{25,19.20}$ Examples of external causes of loneliness are poor accessibility to services, lack of helping skills on behalf of professionals and a negative attitude in society toward ageing. ${ }^{19,20}$ These factors may be influenced by political actions or administrative measures, like improving the standard of education for professionals.

An overview is given in figure 9 of IGC's activities aimed at the older adults of the three neighbourhoods. The accent of activities in neighbourhood I was on behaviour 
change. In the support group widowed women discussed how to build and keep a satisfying social network. ${ }^{96}$ The social skills training course was aimed at improvement of the skills of older adults in making contact. ${ }^{27}$ Moreover a training course was organized for the intermediates to ameliorate helping and cooperation skills. ${ }^{29}$ Although this course was aimed at behaviour change in intermediates, the course is designated as environment oriented, because its target was, from the perspective of older adults, to ameliorate the accessibility of services and quality of care of organizations. In neighbourhood II the services for older adults were extended with new activities: a club house for older adults living in apartment buildings, a contact service to bring together older people who were interested in visiting concerts, shopping, sports etcetera, and a column in a local newspaper with addresses of institutions relevant to older people. This change of the local system of elderly services is characterized in figure 9 as environment oriented. The activities of neighbourhood III were also environment oriented. A motor bus was put into action that served as an information and meeting point for older people who did not visit existing activities on a regular basis. Moreover a help desk was set up to provide intermediates with information about services for lonely older adults (figure 9 ).

- Figure 9. In Good Company's activities for older adults in the three neighbourhoods

\begin{tabular}{|c|c|c|}
\hline & behaviour oriented activities & environment oriented activities \\
\hline neighbourhood I & $\begin{array}{l}\text { support group for widowed } \\
\text { women } \\
\text { social skills training }\end{array}$ & $\begin{array}{l}\text { training course on skills of } \\
\text { professional workers and } \\
\text { volunteers to help older adults } \\
\text { and improve cooperation with } \\
\text { other intermediates or } \\
\text { institutions }\end{array}$ \\
\hline neighbourhood II & & $\begin{array}{l}\text { club house where older adults } \\
\text { can meet } \\
\text { contact service to bring older } \\
\text { people with same hobbies and } \\
\text { interests in contact with each } \\
\text { other } \\
\text { column in local newspaper with } \\
\text { addresses of relevant } \\
\text { institutions for older people }\end{array}$ \\
\hline 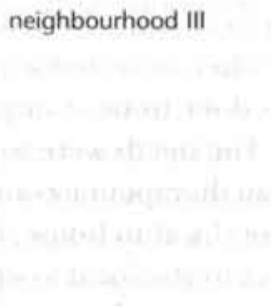 & & $\begin{array}{l}\text { drop in bus, for older adults } \\
\text { who do not visit regular } \\
\text { activities. Information and a } \\
\text { chat is offered } \\
\text { working conferences for } \\
\text { intermediates } \\
\text { help desk which provides } \\
\text { information to intermediates } \\
\text { about services for lonely older } \\
\text { people }\end{array}$ \\
\hline
\end{tabular}




\subsubsection{Linkage strategies}

During the IGC program several strategies were used to link the plans of the city work group and the needs of older adults and intermediates at the local level. In all neighbourhoods local organizations came together in local work groups (figure 10). The IGC newsletters were sent to the intermediates, when the program was operational in their neighbourhood. Training and workshops for intermediates were organized in two neighbourhoods to enhance their interest and to get feedback on program plans. Needs assessments among older inhabitants of neighbourhood II and intermediates of neighbourhood III were conducted. In neighbourhood III the program activities were laid down in a local action plan. The project leader was active as a change agent in all neighbourhoods and facilitated the linkage processes. As IGC was active in succeeding time periods in the three neighbourhoods, the experiences in one neighbourhood could be used to facilitate the planning in the next neighbourhood. It can be seen from figure 10 that the use of democratic strategies increased, considering the needs assessments in neighbourhoods II and III. For a better understanding of the linkage strategies, the history of IGC will be described briefly below. It will become clear that the involvement of intermediates increased during the course of IGC from neighbourhood to neighbourhood.

At the start of IGC the city work group decided to implement in neighbourhood I the support group and social skills course, aimed at older adults, and skills training, aimed at intermediates, which had been proven scientifically to be effective. ${ }^{96-28}$ The organizations cooperating in the local work group were asked to carry out the ideas produced at city level. Although much effort was spent by the local work group in organizing the activities for the older adults, and intermediates were trained in the skills training to spot risk groups of lonely elderly, the result was disappointing. Despite promotion activities like calls in local papers and flyers, only five women participated in the support group for widowed women. Intermediates also met difficulties in recruiting older people for the social skills training, and due to a lack of applicants the social skills training had to be cancelled. The approach used in neighbourhood I can be characterized as an instrumental use of linkage systems to realize ready made program activities planned by the city work group.

The disappointing response in neighbourhood I gave reason to change the linkage approach in neighbourhood II drastically. A needs assessment was conducted among the population of older people in neighbourhood II, using a door to door inquiry, carried out by volunteers, aged 55 years and over (figure 10). The needs were found to be in the field of recreation and meeting facilities, rather than therapeutic courses. The organization of the door to door inquiry and the design of the club house, contact services and newspaper column was almost exclusively left to the local working group, facilitated by the project leader. The local activities were watched over from a distance by the city working group, allowing for a bottom up, democratic linkage approach. 
IGC could build on an existing initiative in neighbourhood III to diminish loneliness in older adults. A group of volunteers and some professionals were already making an inventory of activities where the older inhabitants could meet each other. This initiative took charge of the local working group. The linkage strategy of needs assessment among the intermediates was used (figure 10). The project leader interviewed key figures in the neighbourhood, i.e. professionals and volunteers, to make an inventory of their needs. The local work group designed, with support of the project leader, a local action plan, which had to meet local wishes and needs as well as the advanced set goals and target groups of IGC. The plan included the drop in bus, working conferences and the help desk for the intermediates. The working conferences had the same function as the intermediates' skills training of neighbourhood I, however they were not called 'skills courses' because of some key informants' fear that subscription would be low. The linkage approach again can be typified as democratic. In neighbourhood III, more than in neighbourhood II, the city work group guarded the accomplishment of the program target of improving helping and cooperation skills in intermediates.

- Figure 10. Linkage strategies used in In Good Company

\begin{tabular}{|c|c|c|c|}
\hline & neighbourhood I & neighbourhood II & neighbourhood III \\
\hline local work group & * & * & * \\
\hline newsletter & * & * & • \\
\hline training, workshop & * & & * \\
\hline $\begin{array}{l}\text { needs assessment } \\
\text { older adults }\end{array}$ & & * & \\
\hline $\begin{array}{l}\text { needs assessment } \\
\text { intermediates }\end{array}$ & & & * \\
\hline action plan & & & * \\
\hline
\end{tabular}

\subsubsection{Questionnaire}

The satisfaction of the intermediates with the IGC activities was studied using postal questionnaires. These were sent to between 30 to 50 intermediates per neighbourhood, about 20 months after the introduction of the program in their neighbourhood. The selection criterium of the study group was simply the person's presence on the mailing list of IGC, including general practitioners, district nurses, social psychiatric nurses, volunteers at churches, volunteers active in elderly unions, apartment concierges, policemen, clergymen and social workers. Involvement of the intermediates with the program varied from merely receiving program mail to actively organizing a training course, all replies were anonymous. 
The intermediates' judgement of the program was operationalized using the following questions and scales. The perception of the linkage approach was determined using a 4 item scale $(\alpha=0.90)$. An example of an item was "the local needs for activities aimed at diminishing and preventing loneliness were the first matter of importance for IGC" (table 15). Typification of the IGCactivities was obtained by asking the opinion of the intermediates on the following items. "IGC comprises rather therapeutic activities than recreational activities" and "IGC was especially aimed at lonely older adults and not at all older adults". The satisfaction of the intermediates with IGC was measured by having them rate their overall satisfaction on a 3 point-scale. Intermediates were also asked for their satisfaction with IGC's success in meeting its targets. Finally, the intermediates could give their opinion about the local work group using a 5 item scale; e.g. "the local work group contributed largely at making loneliness activities possible" $(\alpha=0.80)$.

An association was established between the opinions of the respondents to the questions on the one hand and the neighbourhood in which they were active on the other. Neighbourhood was viewed as independent variable. Ordinal dependent variables and scales were analyzed using univariate analysis of variance.

\subsection{Results}

\subsubsection{Response to the questionnaire}

The response among the intermediates of neighbourhood I ( $63 \%)$ equalled that of neighbourhood $\mathrm{II}(61 \%)$ ( $\mathrm{n}=25$ and $\mathrm{n}=33$ resp.). Response in neighbourhood III was highest: $71 \%(\mathrm{n}=37)$. Total response was $66 \%$, because of the anonymity of the replies no exact indication can be given of the degree to which the response group represented the study group, though the response to the questionnaire among volunteers and professionals was fairly equal ( $67 \%$ and $65 \%)$.

\subsubsection{Opinions and satisfaction of intermediates}

The intermediates were asked in the questionnaire to assess the degree to which the IGC program used a bottom up, democratic linkage strategy. It can be seen from table 15 that, corresponding to the description above of IGC, respondents from neighbourhood $\mathrm{I}$ assessed the approach significantly less as democratic compared to respondents from areas $\mathrm{II}$ and $\mathrm{III}$ (mean scale scores resp. 12.7, 14.8, 14.8, p<0.01).

In neighbourhood I the emphasize was on interventions to produce behaviour change in older adults and intermediates. The respondents of neighbourhood I indicated in the questionnaire that the accent of the program was on therapeutic rather than on recreational activities. The respondents of neighbourhood II and III agreed less with this view (mean scores $4.1,2.5,3.4, \mathrm{p}<0.01$ ) (table 15). In the latter neighbourhoods external environmental changes were mainly targeted. Older adults and intermediates were in need of services which had the character of meeting points, like a club 


\begin{tabular}{|c|c|c|c|c|c|c|}
\hline \multirow[b]{2}{*}{ linkage approach } & \multicolumn{2}{|c|}{$\begin{array}{l}\text { neighbourhood I } \\
(\mathrm{N}=25)^{\prime}\end{array}$} & \multicolumn{2}{|c|}{$\begin{array}{l}\text { neighbourhood II } \\
\qquad(\mathrm{N}=33)\end{array}$} & \multicolumn{2}{|c|}{$\begin{array}{l}\text { neighbourhood III } \\
\qquad(\mathrm{N}=37)\end{array}$} \\
\hline & mean & s.d. & mean & s.d. & mean & s.d. \\
\hline $\begin{array}{l}\text { the local needs for activities aimed at diminishing and preventing loneliness were the first matter of importance } \\
\text { for IGC (1-5) } \cdots\end{array}$ & 3.1 & 0.9 & 4.0 & 0.4 & 3.8 & 0.7 \\
\hline IGC had gained sufficient insight into specific problems concerning loneliness in the neighbourhood (1-S) $\cdots$ & 2.6 & 0.9 & 35 & 0.5 & 3.4 & 0.7 \\
\hline performance of IGC activities was the responsibility of professionals and volunteers in the neighbourhood $(1-5)^{*}$ & 3.3 & 1.1 & 3.9 & 0.3 & 3.9 & 0.7 \\
\hline the city work group and project leader fulfilled a supporting and advising role (1-5) & 3.7 & 0.9 & 3.5 & 0.8 & 3.7 & 0.7 \\
\hline scale linkage approach $(4-20)^{\cdots}$ & 12.7 & 2.4 & 14.8 & 1.3 & 14.8 & 1.8 \\
\hline types of interventions & & & & & & \\
\hline ICC comprised rather therapeutic activities than recreational activities (1-5) $\cdots$ & 4.1 & 0.5 & 2.5 & 0.8 & 3.4 & 0.9 \\
\hline ICC was especially aimed at lonely older adults and not at all older adults $(1-5)^{\ldots}$ & 3.8 & 0.9 & 2.9 & 1.0 & 2.8 & 0.9 \\
\hline satisfaction & & & & & & \\
\hline satisfaction with meeting the objective to diminish or prevent lonetiness (1-3) & I.S & 0.5 & 1.4 & 0.5 & 1.7 & 0.6 \\
\hline satisfaction with meeting the objective to ameliorate skills of intermediates $(1-3)^{*}$ & 1.9 & 0.7 & 1.7 & 0.5 & 2.2 & 0.5 \\
\hline satisfaction with meeting the objective to ameliorate cooperation between intermediates $(1-3)^{\cdots}$ & 1.9 & 0.9 & 1.8 & 0.8 & 2.6 & 0.5 \\
\hline $\begin{array}{l}\text { the local work group sufficiently made an inventory of bottlenecks and gaps and worked on the improvement of } \\
\text { loneliness activities }(1-5)^{2}\end{array}$ & 3.0 & 0.5 & 3.6 & 0.7 & 3.2 & 1.0 \\
\hline $\begin{array}{l}\text { the local work group succeeded in colling the attention of organizations and workers to problems in helping } \\
\text { lonely older adults (1-5) }\end{array}$ & 2.8 & 0.8 & 3.2 & 0.8 & 3.7 & 0.8 \\
\hline the local work group contributed targely to making loneliness activities possible (1.5) & 3.0 & 0.6 & 3.3 & 0.9 & 3.8 & 1.0 \\
\hline all relevant disciplines were present in the local work group $(1-5)^{\circ}$ & 27 & 1.0 & 3.6 & 0.7 & 3.6 & 0.7 \\
\hline neighbourhood $(1-5)^{\text {*. }}$ & 3.3 & 1.0 & 3.1 & 0.9 & 4.3 & 0.5 \\
\hline scaie satisfaction with the local work group $(5-25)^{*}$ & 14.7 & 37 & 16.8 & 3.1 & 18.6 & 3.0 \\
\hline overall satisfaction with ICC $(1-3) \cdots$ & 2.0 & 0.8 & 2.1 & 0.7 & 2.7 & 0.5 \\
\hline
\end{tabular}

1 Number of respondents may differ because of item non response.

; Not all respondents participated in the local work groups. The questions about the local work group were answered only by group participants ( $n=7,9,10$ resp.)

- F-test, $p<.1 \cdots$ F-test, $p<05 \cdots$ - F-test, $p<01$ 
house and motor bus for older people and working conferences for intermediates. The respondents of area I had a significantly different opinion about target groups covered by the program. They were in favour of the view that IGC was focused on lonely older adults whereas respondents in area II and III were of opinion that all older people had access to the program (means resp. 3.8, 2.9, 2.8, $\mathrm{p}<0.01$ ).

Satisfaction with realization of the program objective to diminish or prevent loneliness among respondents of the three areas was equally low (means resp. 1.5, 1.4, 1.7, n.s.) (table 15). The respondents of neighbourhood I were somewhat more satisfied with the effectiveness of the program to improve the helping skills of intermediates and to better cooperation, than respondents in area II, but satisfaction was less than in area III (mean score on satisfaction with helping skills 1.9, 1.7 and 2.2 resp. $(\mathrm{p}<0.05)$ and mean score on satisfaction with cooperation between organizations $1.9,1.8$ and 2.6 resp. $(p<0.01))$. The satisfaction with the work group in area I was relatively low and highest in area III (mean scores 14.7, 16.8 and $18.6(\mathrm{p}<0.10)$ ). Overall satisfaction with the IGC program in area I was equal to area II and lower than in area III (mean scores $2.0,2.1$ and 2.7 resp. $(p<0.01)$ ).

\subsection{Discussion and conclusion}

A study was made of the strategies of linkage of program plans and users' needs in the Dutch loneliness intervention program In Good Company. Intermediates in three neighbourhoods where IGC was active were asked for their satisfaction with the program. The intermediates represented professionals and volunteers in the field of health care and social welfare. A possible selective response to the questionnaire has to be taken into account when interpreting the results. Respondents who participated actively and enthusiastically in the program may have filled out the questionnaire, however intermediates who criticized the program may be overrepresented.

In accordance with the contention in the methods section that the use of democratic linkage strategies increased, the intermediates in neighbourhood I thought the linkage strategy of IGC less of a bottom up, democratic process than intermediates in areas II and III. The linkage approach in the first neighbourhood was characterized as instrumental and top down. The city work group tried to implement a pre-designed program, which had to be carried out by the local work group of this neighbourhood. The scores on the linkage approach scale for neighbourhoods II and III were equal. Apart from the regular linkage strategies i.e. work groups and newsletters, needs assessments had been conducted in these neighbourhoods. Although the target populations of the needs assessments differed, older adults or intermediates, this did not influence the appraisal of the linkage strategy used in the two neighbourhoods.

The intermediates of neighbourhood III were on the whole most satisfied with the program. The intermediates' general satisfaction in the other two neighbourhoods was equally lower. The intermediates of neighbourhood III in contrast to neighbourhoods I and II were also most content with the objective to improve helping skills of 
intermediates and cooperation between organizations. Moreover they expressed their contentment with the local work group which was linkage system for the expectations and needs of program designers and users. The intermediates of neighbourhood III were consulted most explicitly, in comparison to the other neighbourhoods, considering the needs assessment and formulation of the local action plan. Although in neighbourhood II a democratic linkage approach was also used, the needs assessment was not aimed at the intermediates. The intermediates' satisfaction in neighbourhood III originated apparently from the attention that was paid to their experience as voluntary or professional workers and their voice in the IGC planning process. The formulation of an action plan, which was unique for neighbourhood III, may have contributed to the intermediates' satisfaction. The result could also have been affected by the inclusion of the initiative which was already going on in neighbourhood III prior to the start of Good Company, to make an inventory of meeting facilities for the older inhabitants. The linkage function of the local work groups was most clear in neighbourhoods II and III, especially in neighbourhood III the city work group acted as gate keeper for its own ideas of program objectives and target groups, while simultaneously allowing for local needs. This did not jeopardize the local intermediates' satisfaction. On the contrary, their satisfaction with the program and local work group was highest.

Satisfaction with realization of the program target to prevent or diminish loneliness was low among the intermediates in all neighbourhoods. The respondents' satisfaction was not affected by the difference between behaviour and environment oriented activities. Although the support group for widowed women and social skills training had been scientifically shown to be efficacious, they encountered too many difficulties to be effective in practice. Older adults seemed to be reluctant to join activities dealing with problems due to loneliness. Moreover the top down introduction of these activities might have caused resistance among intermediates when it came to adoption of the proposed interventions. Studies into social participation by older people show that involvement in recreational or leisure activities is related to a higher degree of wellbeing, however the respondents stayed critical as to the effectiveness of the environment oriented activities.. ${ }^{231}$ The low satisfaction may be explained by the relatively short period of time allowed for data collection, about 20 months after the start of Good Company in the areas; because a lot of time was spent at organisation work, most program activities had only been operational for a short time.

With respect to the state of IGC activities, two years after the city program organization terminated its involvement, in area I no activity was continued, IGC was viewed as a pre-designed one off program. In area II, after a long period of closure due to financial problems and problems in finding a suitable location, the club house has reopened and functions with renewed interest from the older inhabitants living in the apartment buildings. In neighbourhood III several working conferences were organized for the intermediates and the drop in bus and help desk were still operational. In the democratic linkage approach intermediates felt responsible for the continuation of interventions arising at the local level. 
It can be concluded that satisfaction with the IGC program was lowest in the neighbourhood where a pre-designed program was introduced top down, and highest in the neighbourhood in which the intermediates were actively involved in the decision making and development of program activities. In spite of the theoretical effectiveness of the behavioural interventions, they did not come of the ground because users' needs were ignored. The democratic, bottom up linkage approach, allowing for the needs and interests of program users, contrary to the instrumental, top down use of the linkage system, was of crucial importance to the successful dissemination of the IGC program. In health promotion special attention has to be paid to the process of involvement of the intermediates and tailoring program targets to local needs, while keeping an eye on the program objectives and target groups. The proper use of linkage strategies, like a needs assessment, the design of a local action plan and a two way communication between the local and city work groups, is helpful in this process. 


\section{References}

1. Kok G. Why are so many health promotion programs ineffective? Health Promotion Journal of Australia 1993;3:12-17.

2. Oldenburg B, Hardcastle DB, Kok G. Diffusion of innovations. Glanz K, Lewis FM, Rimer BK (eds.) Health behavior and health education; theory, research and practice, 2nd edition. San Fransisco: Jossey-Bass, 1997.

3. Green LW, Kreuter MW. Health promotion planning. An educational and environmental approach (2nd ed.). Mountain View: Mayfield, 1991.

4. Bartholomew LK, Parcel GS, Kok G. Intervention mapping: a process for developing theory-and evidence based health education programs. Health Education \& Behavior 1998;25:545-563.

5. Woelk GB. Cultural and structural influences in the creation of and participation in community health programmes, Soc Sci Med 1992:35:419-424.

6. Orlandi MA, Landers C, Weston R, Haley N. Diffusion of health promotion innovations. Glanz K. Lewis FM, Rimer BK (eds.) Health behaviour and health education; theory, research and practice. San Fransisco: Jossey-Bass, 1990.

7. Dijkstra M, De Vries H, Parcel GS. The linkage approach applied to a school-based smoking prevention program in the Netherlands. J of Sch Health 1993;63:339-342.

8. King L, Hawe P, Wise M. Making dissemination a two-way process. Health Promotion International 1998;13:237-244.

9. Bracht N, Kingsburry L. Community organization principles in health promotion: a five-stage model. In: Bracht N (ed). Health promotion at the community level. Newburry Park: Sage, 1990.

10. Ven, AH van de. Central problems in the management of innovations. Management Science 1986;32:590-607.

11. Dror $\mathrm{Y}$. The planning process: a facet design. Faludi A. A reader in planning theory. Oxford: Pergamon Press, 1978.

12. Vught FA van. Experimentele beleidsplanning; bestuurskundige expedities in de jungle van het planningsdenken. s-Gravenhage: VUGA, 1982.

13. Hanson BS, Isacsson S, Janzon L, Lindell S. Social network and social support influence mortality in elderly men; the prospective population study of "men born in 1914", Malmố Sweden. American Journal of Epidemiology 1989:130:100-111.

14. Oxman ThE, Berkman LF, Kasi S, Freeman DH, Barrett J. Social support and depressive symptoms in the elderly. American Journal of Epidemiology 1992;135:356-368.

15. Yasuda N, Zimmerman SI, Hawkes W, Fredman L, Hebel JR, Magaziner J. Relation of social network characteristics to 5-year mortality among young-old versus old-old white women in an urban community. American Journal of Epidemiology 1997;145:516-523.

16. Penninx BWJH, Tilburg T van, Kriegsman DMW, Deeg DJH, Boeke AJP, Eijk JThM van. Effects of social support and personal coping resources on mortality in old age: the Longitudinal Aging Study Amsterdam. Am J Epidemiol 1997:146:510-519.

17. De Jong-Gierveld J, Kamphuis F. The development of a Rasch-type loneliness scale. Applied Psychological Measurement 1985;9:289-299.

18. Bosma, AMM, Vermeulen CA. De gezondheid van ouderen. Epidemiologie en beleid. Amsterdam: Thesis Amsterdam University, 1992.

19. Pearson RE. Counselling and social support; perspectives and practice. Newbury Park: Sage, 1990. 
20. Mullins LC, McNichols N. Loneliness among the elderly: issues and considerations for professionals in aging. Gerontology and Geriatrics Education 1986;7:55-65.

21. De Jong-Gierveld J. Developing and testing a model of loneliness. Journal of Personality and Social Psychology 1987;53:119-128.

22. De Jong-Gierveld J. Kamphuis F, Dykstra P. Old and lonely? Comprehensive Gerontology; Behavioural, Social and Applied Sciences 1987;1:13-17.

23. Rokach A. Antecedents of loneliness: a factorial analysis. The Journal of Psychology 1989:123:369384.

24. Bowling AP, Edelmann RJ, Leaver J, Hoekel T. Loneliness, mobility, well-being and social support in a sample of over 85 year olds. Personality and Individual Differences 1989:10:1189-1192.

25. Andersson. L. Intervention against loneliness in a group of elderly women: an impact evaluation. Social Science and Medicine 1985;20:355-364.

26. Lammeren P, Geelen K. Verbitteren of verbeteren; evaluatie van een programma ter voorkoming van eenzaamheid en depressie bij oudere weduwen. Utrecht: Netherlands centrum Geestelijke volksgezondheid, 1995.

27. Van den Brink RHS. Effecten van een sociale vaardigheidstraining voor ouderen. Tijdschrift voor Gerontologie en Geriatrie 1991;22:173-180.

28. Linneman M, Leene G, Bettink K. Schram M, Voermans J. Uit eenzaamheid; over hulpverlening bij ouderen. Houten: Bohn, Stafleu, Van Loghum, 1990.

29. Adelmann PK. Multiple roles and psychosocial wellbeing in a national sample of older adults. Journal of Gerontology 1994:49:\$277-285.

30. Kelly JR, Ross J. Later-life leisure: beginning a new agenda. Leisure Sciences 1988;11:47-59.

31. Van Eijk L. Activity and wellbeing in the elderly. Amsterdam; Thesis Publishers, 1997. 


\section{Chapter 7}

Interest in participation in

a peer-led senior health

education program

epidemiological diagnosis
intervention development
effect evaluation 


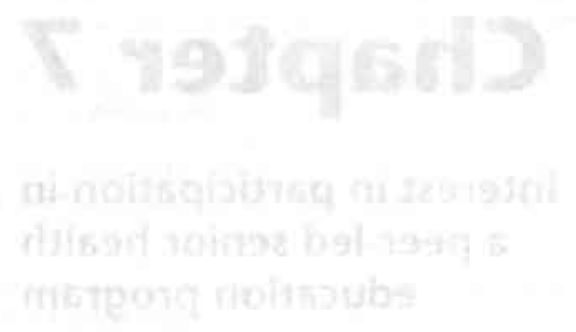

\section{Abstract}

A study was made of the characteristics of older adults showing an interest in participating in a health education course given by peers. Determining the degree of interest in health education is important for assessing the impact on the target-population and evaluating the dissemination strategy. In the course 'Successful Aging' groups of older adults came together to discuss health related issues. The course was given by senior health educators aged 55 years and over from the peer group. To determine interest in the course answer cards were sent with a letter of invitation to all independently living inhabitants aged between 55 and 79 in a Dutch community. The rate of expressed interest in the course was $5.8 \%$. Interest was highest among females in the 55-64 age group, the unmarried and those with low wellbeing. Males in the age group 65-79, females aged 75-79, those with a lower socio-economic status and the inactive were comparatively less interested. Subscription to the course was distinguished from mere interest in the course. From those who expressed interest, more people of low socio-economic status, with a reduced level of wellbeing, many physical limitations and poor self-efficacy actually subscribed. It is concluded that the health education program will be continued and that special attention will be paid to groups that showed lower levels of uptake. Involving intermediates from these groups in the course development is recommended. 


\section{Interest in participation in a peer-led senior health education program}

\subsection{Introduction}

Health education can play an important role in the prevention of disease in older adults and help to improve the quality of their life. There is a growing belief that health gains are attainable in old age. ${ }^{15}$ Preventive measures such as seeking changes regarding alcohol and tobacco use, diet or exercise are to be recommended for all ages, including the oldest. Other interventions are uniquely 'geriatric', such as education to prevent falls or memory training, ${ }^{2.3}$ The body of literature on the relevance and effects of these geriatric preventive efforts is growing ${ }^{6.12}$ Health education as a primary prevention strategy can help older adults to obtain information and learn new skills, enabling them to adopt or maintain a healthy life style. ${ }^{13.14}$

This article focuses on the interest of a group of Dutch senior citizens showed in an educational course. There is only limited information available on the degree of interest in participation in health education programs and the characteristics of participants. The following characteristics are relevant to specify subgroups of participants: gender, age, marital status, social support, socio-economic status, social participation and self-efficacy. These characteristics are related to the perceived or self-reported physical and mental health of older people. ${ }^{15-23}$ Research shows that perceived health in the elderly is a predictor of mortality as an objective health indicator. $^{24.21}$ Studies into participation in health education report the following results. Interest in health programs is highest in women and for the younger members of the old age group..$^{2528}$ The goal of the education program seems to be a decisive factor when the degree of participation in society of the attenders is determined. In a program in which educators visited the elderly at home to discuss various health risks, those willing to participate were more active in clubs or informal groups. ${ }^{27}$ In another community program promoting 'taking greater control of your health in future' participants showed less social activity. ${ }^{26}$ The effect of marital status and social support on participation is not clear. The distribution of socio-economic status and level of self-efficacy among participants is sometimes not in accordance with that of the target groups eligible for joining a health education program. Participation is often highest in the higher socio-economic groups. ${ }^{2528}$ This result is in agreement with findings that adoption of innovations increases with the socio-economic status of individuals, however, because of the relationship between socio-economic status and inequalities in health, health education programs are often aimed at deprived groups. ${ }^{29.30}$ Another discrepancy between the target-population of a program and participation, can be expected in the field of self-efficacy. Self-efficacy is the ability to attain certain desired behaviours as judged by the individual and is a strong predictor of behavioural change. ${ }^{31,32}$ Many health education programs intend to promote self-efficacy related to a specific health behaviour, however there is evidence that individuals prepared for behavioural change, and probably ready to follow a course, judge their self-efficacy to be higher than people who are not yet thinking of chang- 
ing their lifestyle: ${ }^{3 i s}$ Finally, when looking closer to the health status of participants, again interest varies with the objective of the program. In the community program to enhance control of health, mentioned above, participants experienced poorer mental health, while the home-visits program found that participants had a better mental health level. 26,27

Most of the above mentioned studies refer to programs run by professional workers. No information has been published about how health education led by older peers is received. This information is relevant to assess the impact of a program at population-level and the success of the dissemination strategy. ${ }^{35}$ This paper deals with the dissemination of the course 'Successful Aging', aimed at older adults and using members of the peer group as educators. The following research questions are addressed in this paper. Which subgroups of older adults expressed interest in the course? What were the characteristics of those who actually subscribed for the course? What were the rates of expressed interest among the subpopulations? Was the dissemination strategy used suitable?

\subsection{The course 'Successful Aging'}

The course 'Successful Aging' was born out of discontent with traditional health education programs in The Netherlands. These programs focus too much on the problem side of disease, and too little on health promotion. Furthermore, the programs are often designed by professionals with little or no contribution to the program planning from older adults. In 'Successful Aging', the peer educators aged 55 and over (in the project called senior health educators) were involved strongly in the planning and guidance of the course. The senior health educators were trained intensively in a program at a higher educational level, for one day per week for a year. ${ }^{36}$ The training enabled them autonomously to prepare and pass on the health messages. For the course 'Successful Aging', the peer educator introduced the topic at issue before an audience of twenty older adults, followed by peer facilitated discussion. The course consisted of four meetings covering topics requested by the participants.

The improvement of the physical, psychological and social wellbeing of participants was central to the course. The course was promoted as an opportunity to exchange experiences and to learn from other people how to grow old successfully. The course theme 'Successful Aging' was depicted as adding 'extra life' to your existence. Course targets concerned behaviour change on topics like physical exercise, memory training and sleeping habits. The senior health educators were put into action to help fellow citizens to live an independent active life in which growing old is viewed as a challenge. The importance of staying active in old age was stressed by going into general topics like the importance of social support or cultural differences in aging. 'Successful Aging' made use of peers, because it has been proven that educators, who are close to the age, beliefs and social status of the target population, are the most effective in communicating a message. ${ }^{99}$ Moreover they act as role models having themselves an independent and active life.".1 
The senior health educators were put into action in 1995 in Ridderkerk, a community in the urban area of Rotterdam. All 10,454 independently living inhabitants aged between 55 and 79 ( $23 \%$ of the Ridderkerk citizens) were invited, by letter, to participate in 'Successful Aging'. The invitation was signed by the alderman for elderly affairs and public health. In addition, flyers and posters were distributed and a local newspaper gave free publicity. The course was given in an easy to reach centre where many activities for seniors take place. Enrolment was free. The course 'Successful Aging' was general in nature and not aimed at specific risk groups. The dissemination strategy was therefore aimed at the entire population. The Ridderkerk older population was approached with relatively little effort by sending a letter. This paper considers the reactions of the target group to the call to join the course 'Successful Aging'.

\subsection{Methods}

The senior citizens of Ridderkerk could apply to join the course 'Successful Aging' by returning an answer card that was attached to the letter from the alderman. A comprehensive postal questionnaire was sent prior to course commencement to those who sent back the answer card. An abbreviated version of the questionnaire was sent to a random sample of those who had not expressed an interest. The questionnaire was shortened to enhance the response rate. The following response groups emerge (see figure 11):

1. Interest in Participation (IP) group: respondents to the questionnaire sent to course subscribers.

2. Interest Only (IO) group: respondents to the questionnaire, sent to those who did not subscribe in the first instance but who marked their interest in the course on the answer card.

3. No Expressed Interest (NEI) group: respondents to the questionnaire sent to those who did not return the answer card.

\subsubsection{Measures}

The following socio-demographic variables were included in the questionnaires: gender, age, marital status and level of last occupation as an indication of socio-economic status. Furthermore, respondents were asked about social participation by asking whether they engaged in clubs or hobbies with other people outside home. A question was included by which respondents could rate their health from 1 (very bad) to 10 (very good). Psycho-social wellbeing was measured using a shortened version of the validated Dutch scale for subjective wellbeing of the elderly ( 8 items) $(\alpha=0.81) .^{37}$ The next variables were only asked from the IP and IO groups. Physical functioning was measured by a 6 item subscale of the MOS shortform general health survey (MOS20) $(\alpha=0.86){ }^{38-40}$ A Dutch version of the general self-efficacy scale was included in the questionnaire ( 16 items, $\alpha=0.83$ ), ${ }^{41.42}$ Social support was operationalized using the 


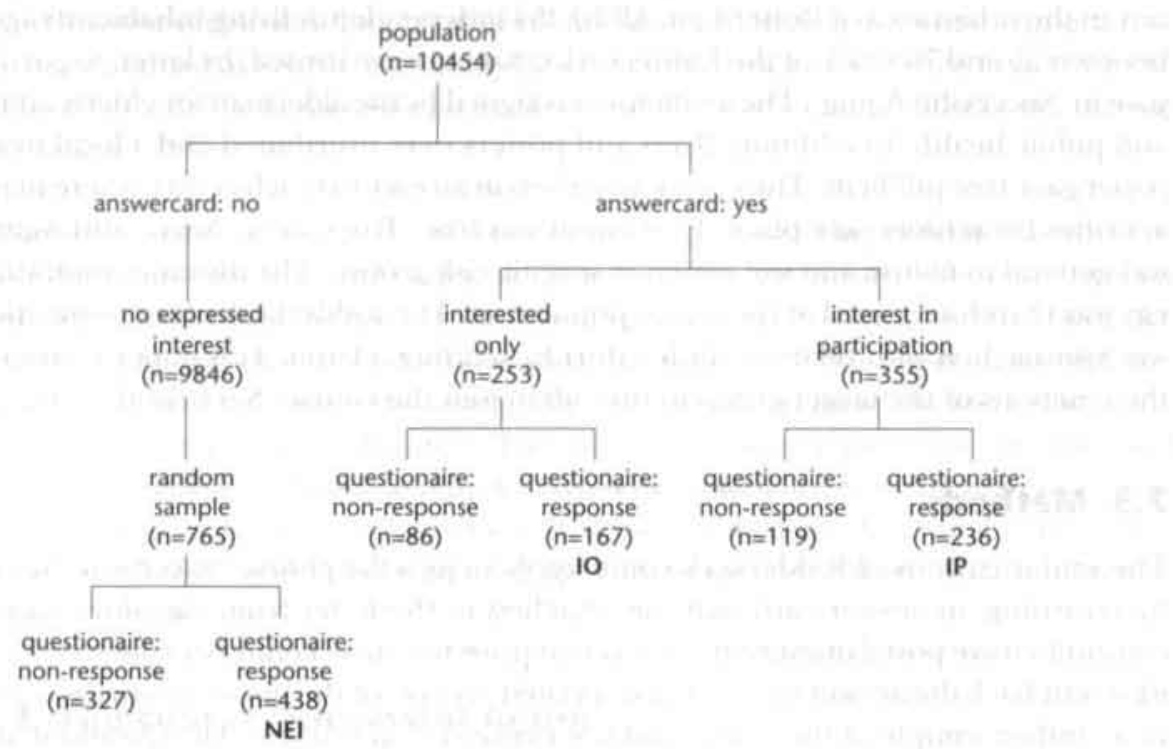

validated scale perception of everyday support ( 10 items, $\alpha=0.88$ ). ${ }^{43}$ The NEI group was asked for reasons why they refused to participate in the course. To get a complete overview, a random sample was drawn from those of the NEI group who did not return the questionnaire. These 100 non-respondents were approached by telephone to get insight into their reasons for not participating.

\subsubsection{Analysis}

Firstly, the response to the questionnaires was studied. Adjustments were made by weighting in the case of selective response. Next, the relationship between expressed interest in the course and background characteristics was established by crosstabulation and testing statistical significance using the Chi-square test. Scale scores were recoded for interpretation reasons, using the 33th and 66th percentiles as cut-off points. To assess predictors of participation, a backward stepwise logistic regression analysis was used, taking into account the effect of other background characteristics. Variables that on a bivariate level were related significantly to expressed interest in the course were entered in the logistic regression equation, as well as significant interactions. Odds Ratio's (ORs) were tested statistically using 95\%-confidence intervals (95\%-CI's). Rates of interest in the course at population level were estimated in groups with characteristics which in the logistic regression model predicted significant interest. ${ }^{\text {note }}$ SPSS $/ \mathrm{PC}+$ was used in the analysis procedures. ${ }^{45}$ 


\subsection{Results}

\subsubsection{Response}

The response rate among those who showed interest in the course was $66 \%$ in both the expressed interest in participation (IP) group and expressed interest only (IO) group. The sample taken from those who did not express interest (NEI) responded at a rate of $57 \%$. Response to the telephone interview among non-respondents was $54 \%$. All results were adjusted by weighting for gender, age and marital status of the non-respondents to account for selective response to the questionnaires.

\subsubsection{Characteristics of interested respondents}

Bivariate comparisons were made between the groups of respondents who expressed their interest in 'Successful Aging' (IP+IO) and those who did not express interest (NEI). The respondents who expressed interest were statistically significant more often female, younger and unmarried, than those who did not react by sending back the answer card (see table 16). Moreover, the interested respondents were more often of a higher occupational level and active in clubs or with hobbies. Interested respondents showed a lower psycho-social wellbeing than those who did not express interest, however the subjective assessment of their health on a scale from 1 to 10 did not differ.

Looking closer at the respondents who expressed their interest, again older adults who subscribed for participation (IP) compared to those only showing interest (IO) were more often female, unmarried and had low wellbeing (table 16). Seniors who were interested in participation (IP) were older and of lower occupational level than the IO group. Moreover, the IP group more often had many physical limitations and experienced low self-efficacy. No association could be proven between interest in participation and social support.

The influence of the other background characteristics on the relationship with interest in the course (IP+IO vs NEI) was controlled for using logistic regression analysis. All variables that were related to expressed interest on a bivariate level, remained in the logistic regression equation (see table 17). Interaction was found between gender and age. Compared to female respondents aged 75 and over, the female age groups 55-64 and 65-74 were more often interested in the course. After controlling for the other variables in the logistic regression model, this relationship became even stronger (ORs respectively 2.72 and 3.94 ). The male age groups did not differ significantly with respect to interest in the course.

\subsubsection{Rates of expressed interest in the population}

In total 608 senior inhabitants reacted to the call to join the course 'Successful Aging' by returning the answer card ( $\mathrm{IP}+\mathrm{IO}$ ) (see figure 11). This amounts to a rate of 
- Table 16. Characteristics of respondents in groups, expressed interest in participation (IP), expressed interest only (IO) and no expressed interest (NEI)

\begin{tabular}{|c|c|c|c|c|c|}
\hline & & $\underset{\substack{1 \\
(n=403)}}{10}$ & $\begin{array}{c}\text { NEI } \\
(n=438)\end{array}$ & $\begin{array}{r}\text { IP } \\
(\mathrm{n}=236)\end{array}$ & $\begin{array}{r}10 \\
(n=167)\end{array}$ \\
\hline & & $\%$ & $\%$ & $\%$ & $\%$ \\
\hline \multirow[t]{2}{*}{ gender } & male & . 40.1 & 47.7 & $\bullet 35.6$ & 46.3 \\
\hline & female & 59.9 & 52.3 & 64.4 & 53.7 \\
\hline \multirow[t]{3}{*}{ age } & 55.64 & 55.6 & 46.0 & $* 48.7$ & 65.0 \\
\hline & $65-74$ & 36.3 & 42.2 & 40.4 & 30.6 \\
\hline & 75.79 & 8.1 & 11.8 & 10.8 & 4.4 \\
\hline \multirow[t]{2}{*}{ marital status } & married & × 69.0 & 78.1 & $* 62.4$ & 78.1 \\
\hline & unmarried & fthit $\quad 31.0$ & 21.9 & 37.6 & 21.9 \\
\hline occupational & low & $\cdot 32.3$ & 40.1 & $\cdot 37.2$ & 25.8 \\
\hline \multirow{2}{*}{ level } & moderate & 29.8 & 33.1 & 32.8 & 26.0 \\
\hline & high & 37.9 & 26.8 & 30.0 & 48.2 \\
\hline \multirow[t]{2}{*}{ activities/hobbies } & yes & 83.6 & 77.0 & 82.9 & 84.5 \\
\hline & no & 16.4 & 23.0 & 17.1 & 15.5 \\
\hline health & low & 43.7 & 42.8 & 46.7 & 39.6 \\
\hline \multirow[t]{2}{*}{ assessment } & moderate & 33.9 & 28.3 & 33.2 & 34.9 \\
\hline & high & 22.4 & 28.9 & 20.1 & 25.5 \\
\hline \multirow[t]{3}{*}{ wellbeing } & low & 41.6 & 29.8 & -48.0 & 33.0 \\
\hline & moderate & 30.8 & 23.9 & 25.2 & 38.3 \\
\hline & high & 27.6 & 46.4 & 26.8 & 28.7 \\
\hline physical & many & - & - & $\cdot 33.5$ & 17.5 \\
\hline \multirow{2}{*}{ limitations } & moderate & & & 32.7 & 38.6 \\
\hline & no & & & 33.8 & 43.9 \\
\hline \multirow[t]{3}{*}{ self-efficacy } & low & $=$ & - & $* 40.5$ & 34.9 \\
\hline & moderate & & & 38.8 & 33.4 \\
\hline & high & & & 20.6 & 31.7 \\
\hline \multirow[t]{3}{*}{ social support } & low & - & - & 34.5 & 38.2 \\
\hline & moderate & & & 34.5 & 31.8 \\
\hline & high & & & 31.0 & 30.0 \\
\hline
\end{tabular}

- $(\mathrm{PP}+\mathrm{IO})-\mathrm{NEI}$, Chi-square $\mathrm{p}<0.05$

- IP - 10, Chi-square p<0.05

- not studied

expressed interest of $5.8 \%$ of the Ridderkerk population 55 to 79 years of age. Respondents to the questionnaire who did not show interest (NEI) and non-respondents who were interviewed by telephone gave the following reasons for not participating (see table 18). About one third preferred other sources of information about healthy lifestyles, like the mass-media. Only a minority (13\%) preferred to get information from their general practitioner. About $20 \%$ was too busy to attend a course and $13 \%$ still had a job. The theme 'Successful Aging' did not appeal to $19 \%$ of the respondents. Poor health was the reason given by $7 \%$ for the lack of interest in the course. 
- Table 17. Odds Ratio's logistic regression model (outcome: expressed interest (IP+IO) vs no expressed interest (NEI))

\begin{tabular}{|c|c|c|c|c|c|}
\hline & & $\begin{array}{r}\text { uncorrected } \\
\text { ORs }\end{array}$ & $95 \%-C . I$. & $\begin{array}{r}\text { corrected }^{\prime} \\
\text { ORs }\end{array}$ & 95\%-C.I. \\
\hline \multicolumn{6}{|l|}{ wellbeing } \\
\hline high & & 1.00 & & 1.00 & \\
\hline moderate & & 2.17 & $1.51-3.11$ & 2.20 & $1.49 \cdot 3.25$ \\
\hline low & & 2.35 & $1.68-3.29$ & 2.45 & $1.66-3.62$ \\
\hline \multicolumn{6}{|c|}{ occupational level } \\
\hline low & & 1.00 & & 1.00 & \\
\hline moderate & & 1.12 & $0.79-1.58$ & 1.23 & $0.83-1.83$ \\
\hline high & & 1.76 & $1.25-2.48$ & 1.93 & $1.31 \cdot 2.86$ \\
\hline \multicolumn{6}{|c|}{ activities/hobbies } \\
\hline no & & 1.00 & & 1.00 & \\
\hline yes & & 1.52 & $1.07-2.18$ & 1.55 & $1.07-2.41$ \\
\hline \multicolumn{6}{|l|}{ marital status } \\
\hline married & & 1.00 & & 1.00 & \\
\hline unmarried & & 1.60 & $1.17-2.18$ & 1.47 & $0.99-2.17$ \\
\hline gender & age & & & & \\
\hline male & $75-79$ & 1.00 & & 1.00 & \\
\hline male & $65-74$ & 0.99 & $0.48 \cdot 2.08$ & 1.12 & $0.49-2.54$ \\
\hline male & $55-64$ & 1.20 & $0.58-2.47$ & 1.04 & $0.47-2.33$ \\
\hline female & $75-79$ & 1.00 & & 1.00 & \\
\hline female & $65-74$ & 1.52 & $0.78-2.96$ & 2.72 & $1.12 \cdot 6.59$ \\
\hline female & $55-64$ & 2.37 & $1.24-4.55$ & 3.94 & $1.65 \cdot 9.40$ \\
\hline
\end{tabular}

'Controlled for the other background characteristics in the logistic regression model

- Table 18. Reasons for not expressing interest in the course "Successful Aging" ( $N=482)$

\begin{tabular}{|lr|}
\hline I'm getting sufficient information about healthy lifestyles from newspapers, television etc. & $29 \%$ \\
I'm too busy with other activities & $21 \%$ \\
"Successful Aging" does not appeal to me & $19 \%$ \\
I'd rather obtain information from my G.P. & $13 \%$ \\
I'm still in work & $13 \%$ \\
My health does not allow me to participate & $7 \%$ \\
\hline
\end{tabular}

Figure 12 includes rates of expressed interest of subgroups with characteristics that turned out to be predictors in the logistic regression analysis. The diagram shows that interest was relatively high in the subgroups of older adults with low or moderate wellbeing: rates of interest of $7.9 \%$ and $7.4 \%$ against $3.6 \%$ in the subgroup of those with high wellbeing. Other high interest groups were those of high occupational level, females aged 55-64 and unmarried persons (rates of interest of about $8 \%$ against $5.8 \%$ 
in the whole). Low interest groups (rates of expressed interest of about $4 \%$ ) were, apart from the earlier mentioned older adults with high wellbeing, males aged from 65 to 74 and 75 and over, women 75 to 79 , and those who were not active in clubs or with hobbies.

- Figure 12. Estimated rates of expressed interest in the course "Successful Aging" at population level

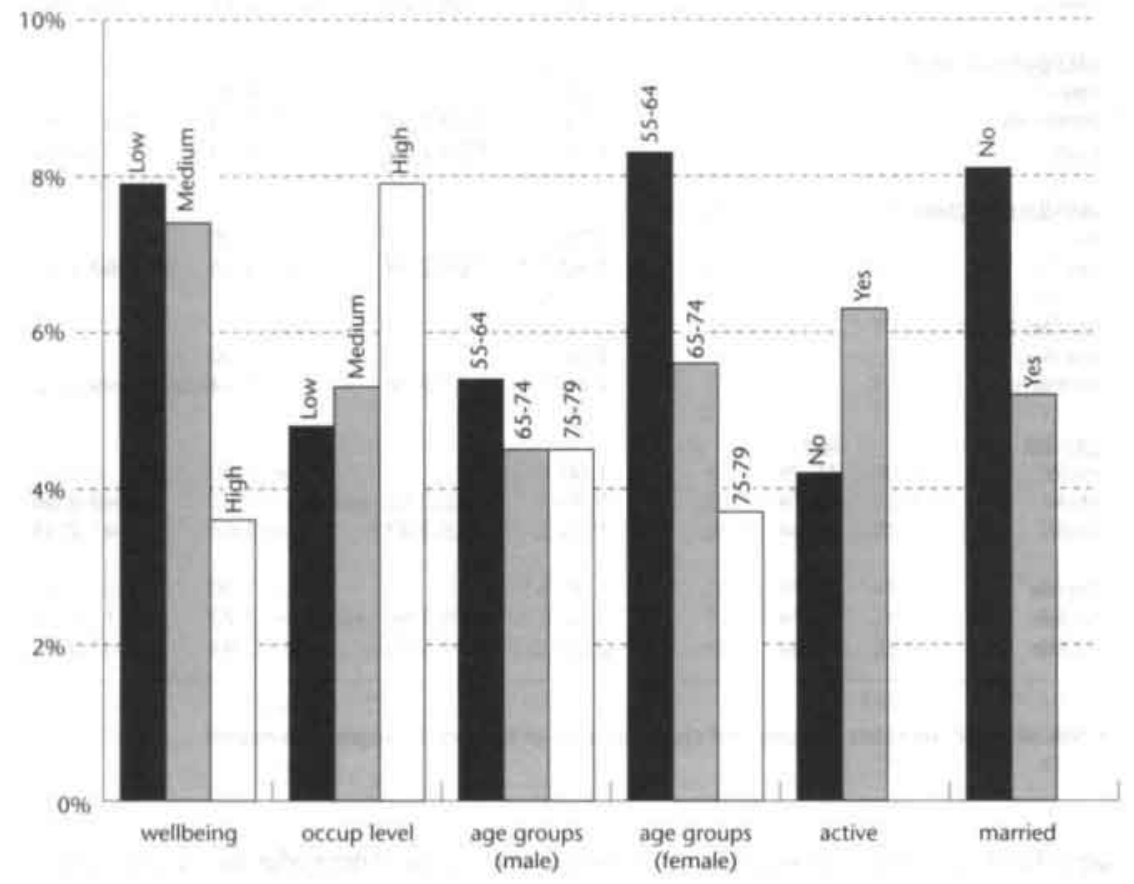

\subsection{Discussion}

The characteristics of older adults showing interest in the peer led course 'Successful Aging' and their degree of interest were studied. The results, combined with evaluation of the effectiveness of the course, are important for assessing the impact of the program on the population. Moreover insight into the characteristics of the groups reached is relevant for the development of future dissemination strategies. The course 'Successful Aging' was aimed at improvement of the physical, psychological and social wellbeing of older adults. Small groups discussed health related issues like physical exercise and memory problems under the guidance of specially trained senior health educators from their peer group.

The interest in the older Ridderkerk community was highest among subpopulations that are eligible for a health education program. Older adults who showed interest, irrespective of whether or not they subscribed for the course $(\mathrm{IP}+\mathrm{IO})$, were younger 
than those who did not express interest (NEI). From a preventive point of view the course is very relevant to this younger age group when preparing for old age. From research there is evidence that female older aduits and those who are unmarried or widowed are risk groups for health problems. ${ }^{17,18}$ People expressing an interest in 'Successful Aging' meet this risk group profile, however the interest shown by the unmarried raises the question whether their interest may be caused by the need to meet new friends. The message of the course how to add 'extra life', attracted the interest of the risk group of older adults with lower wellbeing. This result has also been found in a similar program promoting 'taking greater control of your health' ${ }^{27}$ Unfortunately the risk group of people with low socio-economic status demonstrated less interest than those with higher socio-economic status. Moreover nonactive people seem to face a barrier to join a health education program.

Although the group who expressed interest in the course already showed a need to reflect on their lifestyle, the people who actually subscribed for the course were the most open to joining a course in which their life style was discussed. Within the interested group, the characteristics of those who subscribed for the course (IP) against those who waited to participate (IO) were analyzed. Again, females and unmarried people were more often ready to participate. The 55-64 age group was more frequently only interested, while older age groups more often subscribed for the course. Subscription was also higher among those with lower wellbeing and many physical problems. The theory that groups of higher socio-economic status are more willing to adopt innovations, is not entirely applicable to the selective population showing interest in the course. ${ }^{29}$ The group with the lowest socio-economic status was more often ready to participate and subscribed for the course, whereas those from the higher socio-economic status group only showed interest. Moreover, it was expected that individuals prepared for behavioural change and probably ready to engage in the course, judged their self-efficacy to be higher than the people not yet thinking of changing their lifestyle. ${ }^{33,44}$ Our findings are in contrast with this hypothesis. Senior citizens, who subscribed for the course, experienced lower self-efficacy. An explanation may be that the higher self-efficacy group, who only showed interest, is less in need of the course because they adapt relatively more easily to a healthy lifestyle and lead an independent life. The readiness to participate of those with lower socio-economic status, lower wellbeing, many physical problems and lower self-efficacy, indicates that they had the most prominent need of a new perspective on their lives.

Every inhabitant of Ridderkerk aged 55-79 years had the chance to enrol for the course 'Successful Aging' in the dissemination strategy. Each one received an invitation at home from the alderman for elderly affairs and public health. Six out of a hundred people in the age category reacted to this first call to participate. Most programs confine their strategy to calls in newspapers and flyers. A campaign in which 10,000 postal invitations are distributed is very costly. The question can be raised whether this effort is reflected in the rates of expressed interest. The information available through the mass media about healthy lifestyles was a reason given for not reacting on the invitation to join the course. Other valid reasons for lack of interest were that indi- 
viduals were too busy with other activities or a daytime job, or they had health problems. Most people accepted the peer educator as a source of information. Only $13 \%$ preferred their general practitioner.

Although 'Successful Aging' was aimed at the entire community of older adults of 55 to 79 years of age, the impact in this community will be limited on account of the rate of interest. Nevertheless the course caught the attention of people from several risk groups who were prepared to exchange experiences and to learn from each other about growing old successfully. Provided that 'Successful Aging' is effective, the course may have brought benefit to the attending individuals. The course meets the probIem of the prevention paradox, which states that a program that realizes significant impact for individuals will have limited effect for the population as a whole and vice versa. ${ }^{46} \mathrm{~A}$ health education campaign that pursues considerable behaviour change in every single member of a population will be too extensive and costly.

The direct mail strategy used has taught us which groups of older adults are inclined to participate. In future the program will continue for groups that already showed some interest and special attention will be paid to groups that showed lower levels of uptake, like the socio-economically deprived and inactive. So far the peer educators have been involved in program planning, instead of working with the target population at a local level. In future plans, representatives of the subgroups, older adults themselves and professional advocates, will be consulted to tailor the intervention and enhance interest rates. Platforms or linking systems have to be realized, in which program planners and intermediates come together. ${ }^{47}$ The consequence of this community approach is that the course 'Successful Aging' will be subject to change. The course may even not be the most suitable intervention strategy to interest hard to reach groups, and combinations with other methods such as home visits or environmental change may be necessary to achieve a satisfactory impact.

nute 2Estimates of distribution of background-characteristics at population-level are based on the questionnaire-results among the IP, $1 \mathrm{O}$ and $\mathrm{NEI}$ groups. ${ }^{44}$

$$
I_{s}=\sum_{m}^{3}\left[R_{2} \cdot \frac{P_{1}}{R_{i}}\right]
$$

I. = estimated number of people with characteristic $\mathrm{x}$ in the entire population

$R_{\mathrm{Q}}=$ respondents with characteristic $\mathrm{x}$ in group $\mathrm{i}$ (IP, 1O, NEI)

$\mathrm{R} \quad=$ respondents in group $\mathrm{i}$

$P_{1}=$ size of group $i$ in population

$\mathbb{R}_{0}=\frac{I_{00}+I_{.10}}{1 .}$

1. = estimated number of people with characteristic $\mathrm{x}$ in group $\mathrm{i}$

$\mathbb{R}_{\text {. }}=$ rate of expressed interest in population with characteristic $\mathrm{x}$ 


\section{References}

1. Carter WB, Mckenna M. Martin ML, Andresen EM: Health education: special issues for older adults. Patient Educ Couns 1989;13:117-131.

2. German PS, Fried L.P: Prevention and the elderly: public health issues and strategies. Annu Rev Public Health 1989;10:319-332.

3. Carethers M: Health promotion in the elderly. Am Fam Physician 1992;45:2253-2259.

4. Kutner NG, Ory MG, Baker DI, Schechtman KB, Hornbrook MC, Mulrow CD: Measuring the quality of life of the elderly in health promotion intervention clinical trials. Public Health Rep 1992;107:530-539.

5. Fried LP, Bush TL: Morbidity as a focus of preventive health care in the elderly, Epidem Rev 1988:10:48-64.

6. Cwikel J. Fried AV: The social epidemiology of falls among community-dwelling elderly: guidelines for prevention. Disabil Rehabil 1992;14;113-121.

7. Graafmans WC, Ooms ME, Hotstee HMA, Bezemer PD, Bouter LM, Lips P: Falls in the elderly: a prospective study of risk factors and risk profiles. Am J Epidemiol 1996:143:1129-1136.

8. Tinetti ME, Baker DI, McAvay G, Claus EB, Garrett P, Gottschalk M, Koch ML. Trainor K, Horwit RI: A multifactorial intervention to reduce risk of falling among elderly people living in the community. N Engl J Med 1994:331:821-827.

9. Hahn A, Beurden E van, Kempton A, Sladden T, Garner E: Meeting the challenge of falls prevention at the population level; a community-based intervention with older people in Australia. Health Promotion Int 1996; 11:203-211.

10. Scogin F, Bienias JL: A three-year follow-up of older adult participants in a memory-skills training program. Psychology and aging 1988;3:334-337.

11. Stigsdotter Neely A, Bäckman L: Long-term maintenance of gains form memory training in older adults: two 3-year follow-up studies. J Gerontology: Psychol Sc 1993;48:P233-P297.

12. Commissaris CJAM, Verhey FRJ, Ponds RWHM, Jolles J. Kok GJ: Public education about normal forgetfulness and dementia: importance and effects. Patient Educ Couns 1994:24:109-116.

13. Caserta MS: Health promotion and the older population: expanding our theoretical horizons.J Community Health 1995:20:283-292.

14. Coleman PG: Personal adjustment in late life: succesful aging. Rev Clin Gerontology 1992:2:6778 .

15. Grand A, Grosclaude P. Bocquet H, Pous J, Albarede JL: Predictive value of life events, psychosocial factors and self-rated health on disability in an elderly rural french population. Soc Sci Med 1988:12:1337-1342.

16. Himmelfarb S: Age and sex differences in the mental health of older persons. J Consult Clin Psychol 1984:52:844-856.

17. Jagger C, Clarke M, Cook AJ: Mental and physical health of elderly people: five year follow-up of a total population. Age Ageing 1989;19:77-82.

18. Umberson D. Wortman CB, Kessler RC: Widowhood and depression: explaining long-term gender differences in vulnerability. J Health Soc Behav 1992;33:10-24.

19. Wolinsky FD, Coe RM, Miller DK, Prendergast JM: Correlates of change in subjective well-being among the elderly. J Community Health 1985;10:93-107. 
20. Grembowski D. Patrick D. Diehr P, Durham M, Beresford S, Kay E, Hecht J: Self-efficacy and health behaviour among older adults. J Health Soc Behav 1993:34:89-104.

21. Rodin J, McAvay G: Determinants of change in perceived health in a longitudinal study of older adults: J Gerontology: Psychol Sc 1992;47:P373-P384.

22. Becket LA, Brock DB, Lemke JH, Mendes de Leon CF, Guralnik JM, Fillenbaum GG, Branch, LG, Wetle TT, Evans DA: Analysis of change in self-reported physical function among older persons in four population studies. Am J Epidemiol 1996;143:766-778.

23. Strawbridge WJ, Cohen RD, Shema SJ, Kaplan GA: Successful aging: predictors and associated activities. Am J Epidemiol 1996;144:135-141.

24. Grant MD. Piotrowski ZH, Chappell R: Self-reported health and survival in the longitudinal study of aging, 1984-1986. J Clin Epidemiol 1995:48:375-387.

25. Carter WB, Elward K. Malmgren J, Martin ML., Larson E: Participation of older adults in health programs and research: a critical review of the literature. Gerontologist 1991;31:584-592.

26. Buchner DM, Pearson DC: Factors associated with participation in a community health promotion program: a pilot study. Am J Public Health 1989;79:775-777.

27. Wagner EH, Grothaus LC. Hecht JA, LaCroix AZ: Factors associated with participation in a senior health promotion program. Gerontologist 1991:31:598-602.

28. Macleod P, Stewart NJ. Predictors of participation in a peer-led exercise program for senior women. Can J Nurs Res 1994:26:13-25.

29. Rogers EM: Diffusion of innovations. 3d ed. New York: The Free Press, 1983.

30. Mackenbach JP. Socio-economic health differences in the Netherlands: a review of recent empirical findings. Soc Sci Med 1992;34:213-226.

31. Bandura A: Social foundations of thought and action; a social cognitive theory. Engelwood Cliffs NJ: Prentice Hall, 1986.

32. Ajzen I, Madden Th J: Prediction of goal-directed behaviour: attitudes, intentions, and perceived behavioral control.J Exp Soc Psychol 1986:22:453-474.

33. Prochaska JO, DiClemente CC: Toward a comprehensive model of change. In: Miller WR, Heather $\mathrm{N}$ : Treating addictive behaviors; processes of change. New York: Plenum Press, 1986.

34. Prochaska JO, Redding CA, Harlow L.L, Rossi JS, Velicer WF: The transtheoretical model of change and HIV prevention: a review. Health Educ Q 1994;21:471-486.

35. Parcel GS, Perry L. Taylor WC. Beyond demonstration; diffusion of health promotion innovations. In: Bracht $\mathrm{N}$ ed. Health promotion at the community level. Newbury Park: Sage; 1990.

36. Kemme G, Educating senior health educators; report concerning education and emancipation of people in "the third age". Rotterdam: Hogeschool Rotterdam \& Omstreken. 1995.

37. Linschoten CP van, Gerritsen JC, Romijn C: De Schaal Subjectief Welzijn Ouderen nader onderzocht. Tijdschr Gerontol Geriatr 1993;24:57-65.

38. Stewart AL, Hays RD, Ware JE: The MOS Short-form General Health Survey; reliability and validity in a patient population. Medical Care 1988;26:724-735.

39. Kempen GIJM: Het meten van de gezondheidstoestand van ouderen; een toepassing van een Nederlandse versie van de MOS-schaal. Tijdschr Gerontol Geriatr 1992;23:132-140.

40. Kempen GIJM: The MOS Short-form General Health Survey; single item versus multiple measures of health-related quality of life: some nuances. Pychol Rep 1992;70:608-610. 
41. Sherer M, Maddux JE, Mercandante B, Prentice-Dunn S, Jacobs B, Rogers RW: The self-efficacy scale; construction and validation. Psychol Rep 1982;51:663-671.

42. Bosscher R, Laurijssen L, Boer E de: Competentie op latere leeftijd: een exploratieve studie. Bewegen \& Hulpverlening 1992;9:255-265.

43. Sonderen E van: Het meten van sociale steun. Groningen Dissertation, 1991.

44. Oddy WH, Holman CDJ, Corti B, Donovan RJ: Epidemiological measures of participation in community health promotion projects. Int J Epidemiol 1995;24:1013-1021.

45. Norusis MJ: SPSS/PC+, Chicago, 1992.

46. Rose G. Sick individuals and sick populations. Int J Epidemiol 1985;14:32-38.

47. Orlandi MA, Landers C, Weston R, Haley N: Diffusion of health promotion innovations. In: Glanz K, Lewis FM, Rimer BK eds. Health behaviour and health education; theory, research and practice. San Fransisco: Jossey Bass, 1990. 


\section{Chapter 8}

Effects of a peer-led senior health education program 


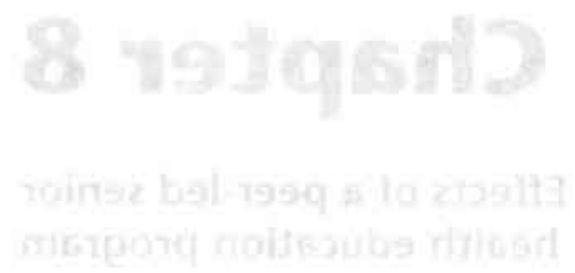

\section{Abstract}

The effect of a health education course guided by peers aged 55 and over was evaluated. The aim of the course was to empower older adults to participate in society and to promote their wellbeing. Evaluation included determining the effect on attitude toward aging, self-efficacy, perception of the societal opinion regarding the place of the elderly in society (social influence), social participation, perceived social support, and wellbeing of the participants aged 55 to 79 years. A quasi-experimental approach was used. The effect on the experimental group of course participants was studied compared to a control group of older adults on the waiting list. The respondents filled out postal questionnaires at three time points (before starting the course (t0), immediately after termination ( $\mathrm{t} 1)$ and three months later (t2)). Using a multivariate analysis procedure, a significant interaction effect between time of measurement and group membership was found with respect to the outcome of social influence. At $t 1$ an effect was absent, but at t2, the current idea that elderly occupy a marginal position in society, found less favour with the experimental group than the control group. Moreover perceived social support and subjective health improved significantly at $\mathrm{t} 1$ and $\mathrm{t} 2$ among the course members, when compared to the control group. No effect was found on attitude, self-efficacy, social participation and wellbeing in the short time span of a three months follow-up. 


\section{Effects of a peer-led senior health education program}

\subsection{Introduction}

Involvement in activities by older adults is associated with a higher degree of wellbeing. A relationship has been found between engagement in voluntary or leisure activities and subjective wellbeing in several studies, however this relationship is modified by health, socio-economic status and marital status. ${ }^{14}$ Unmarried older adults, those who experience health problems and those who have a low income, benefit the most from activity participation. This positive association between high activity level and wellbeing gives support to the 'activity theory' which states that, unless inhibited by physical problems, the needs of older adults in the area of social interaction, are the same as those of young people. Older adults seek to fulfil multiple roles and to keep contact with their social environment. ${ }^{5.1}$ This is the opposite of the 'disengagement theory' by which elderly people choose to diminish their interaction with the environment. The reduction in attention paid to other people and increase of care for the self is viewed, in this theory, as a natural process ${ }^{57}$ Continuation of social participation can be characterized as differential disengagement. ${ }^{8}$ Elderly people cease their involvement in some areas when retiring, while continuing and intensifying their activities in other areas, like leisure time pursuits or grandparenting.

The importance of having social ties is also shown by the beneficial effect of social support on the health and wellbeing of older people. Longitudinal studies show less mental health problems and mortality among older adults who experience a high availability of adequate social support. ${ }^{12}$ When social support is absent, support groups can function as an alternative to provide older adults with information, emotional support or services. Health education programs which make use of peers have the potential to become a surrogate support system for people in need. Examples include peer-facilitated workshops or support groups where people can exchange their experiences with health problems. ${ }^{13,14}$

An evaluation of the effectiveness of the health education course 'Successful Aging' is presented in this article. In this course, guided by peers aged 55 years and over, older adults discussed health related topics like memory problems, housing and use of medicines. The course objectives at a more general level were evaluated. The general aim of the course was to promote social participation, social support and wellbeing. Unlike most evaluation research of health education programs, this article does not consider the effectiveness of the course in achieving health related program targets. This article addresses the following question. Was the course 'Successful Aging' effective in improving the determinants of social participation, social participation, social support and wellbeing of its members? The contents, behavioural model and strategies of the course are explained in more detail below. 


\subsection{Outline of the course 'Successful Aging'}

\subsubsection{Course contents}

The course 'Successful Aging' was organized in Ridderkerk, a community in the urban area of Rotterdam. Both the national and local government in the Netherlands support activities that provide older adults with the opportunity to participate in society and to live a meaningful life. 'Successful Aging' was organized in support of this policy of empowering older adults to stay active. The course was designed to encourage participation in (health promotion) activities, for example, social clubs, exercise programs and memory training. Moreover, the course was aimed at changing participants' behaviour in health risk areas. Changes in behaviour affecting health and social participation were expected to promote the central target of the program: improvement of the social, psychological and physical wellbeing of older adults. The course was facilitated by peers, aged 55 years and over, called senior health educators, who had received intensive training, prior to the course. Groups of about 20 older people met each other, once a week, on four occasions. Every meeting consisted of an introduction, given by the senior health educator, of a topic relevant to individuals facing the aging process, followed by a peer facilitated discussion. The first session started with a general introduction. Guided by the senior health educator, determinants of successful aging like social support, healthy life-styles, sufficient income and self-efficacy were considered. The group was free to choose which topics they wanted to discuss at the following three sessions. Every session dealt with one topic and lasted two hours. The following topics were chosen in the six courses that were evaluated: sleeping problems, memory problems, use of medicines, housing of older adults, osteoporosis, physical exercise and growing old in different cultures.

\subsubsection{Behavioural model}

Ajzen's theory of planned behaviour and Bandura's social learning theory were used in the program design. ${ }^{15,16}$ The program was based on the assumption that social participation is related to three determinants: attitude towards aging, the influence of societal opinion (social influence) regarding the role of the elderly in society, and finally self-efficacy in engaging in new activities (figure 13). It was hypothesized that engagement in activities can be determined by a positive or negative attitude towards aging. A positive evaluation of existence as an older person, would have a positive influence on a person's capacity to stay active. The second determinant, social influence, is defined as the processes whereby people, directly or indirectly, influence the thoughts, feelings and actions of others. ${ }^{17}$ The course was aimed at the individual's perception of societal opinion. In contrast to the disengagement-theory, it was argued that older adults in general, do not wish to diminish interaction with society. They continue activities and develop new interests to substitute for losses caused by the changes brought about by retirement. It was postulated that when people consider themselves to be productive persons who can contribute to society, instead of the prevailing norm that elderly have a little say, they will be inclined to participate in 
activities. The third determinant, self-efficacy from Bandura's social learning theory, is a powerful determinant of behavioural change. Self-efficacy is similar to perceived behavioural control in the theory of planned behaviour, meaning a person's expectation regarding his capability to realize a desired behaviour. ${ }^{16,1820}$ Studies among older adults indicate that individuals with high self-efficacy are more likely to change their behaviour and experience better physical and mental health. ${ }^{21.3}$ In the theoretical model presented in this article it is postulated that when an individual's perception of self-efficacy in starting new activities is high, they will more likely be successful in engaging in these activities. Participation in 'Successful Aging' in the model is not only connected indirectly to social support and wellbeing through the promotion of social participation and its determinants. Participation in the course, being an act representing an active life, will also have a direct effect on the perceived social support and wellbeing of its members (figure 13). The behavioural model used in 'Successful Aging' and presented in this article was based on hypotheses, which have to be studied in more depth.

- Figure 13. Theoretical model of effect of course participation

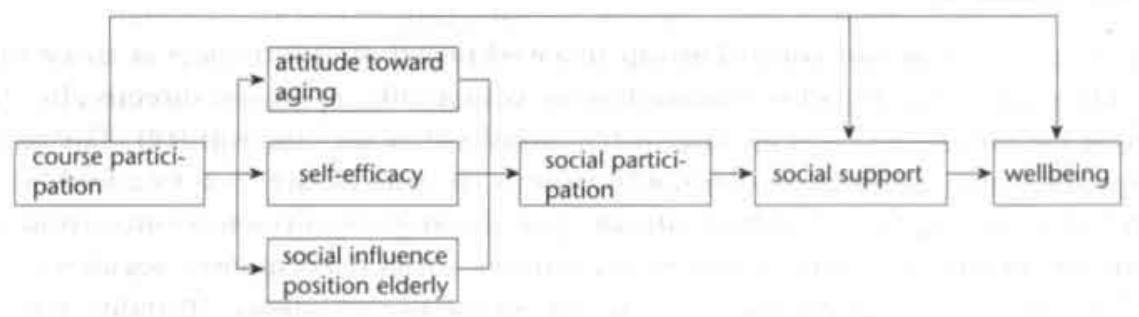

\subsubsection{Course strategies}

Information transfer, role modeling, education by peers and group interaction were strategies used in the course. The senior health educators passed on information to fellow senior citizens about healthy lifestyles. The introduction of health issues was used as a vehicle to discuss repeatedly the three determinants of social participation. For instance in a session about forgetfulness, the senior health educator addressed the question of barriers to subscribe for a memory training course, thus the self-efficacy to participate in memory training became an issue. The senior health educators communicated continuously the message that older people can make an important contribution to society, and opposed the common idea that they play only a marginal role. The educators served as role models, representing older adults who still have a say. ${ }^{16}$ They fulfil the policy target of social participation and function as an example for successfully living an independent and active life. Use of peers enhances the credibility of the information given by the health educator ${ }^{24} \mathrm{It}$ was expected that communication using peer educators, who were close in age, beliefs, and social status, to the target population, would be more effective. Finally, course members learned from each other, during the discussions and group interaction sessions, where information and experiences were exchanged, and social support was available. 


\subsection{Method}

All 10,454 independent living older adults, aged 55 to 79 years, in the community of Ridderkerk were invited by direct mail to participate. A more detailed explanation of this procedure is discussed in a seperate paper on characteristics of people interested in participation in the course 'Successful Aging'. $\$$. At the start of the course, 320 individuals were interested in participation. Later more people subscribed to the course, but they were excluded from the evaluation research. In the order in which the applications were received, 150 individuals were assigned to the experimental group. This procedure was chosen because of the shortage of time before course commencement, and because of the short time-span, it was not expected that 'early' subscribers would differ from 'late' subscribers. A total of 138 applicants participated in the course. The experimental group was split up into six course groups. The other 182 interested people formed the control group and were given the opportunity to join the course after the research period.

\subsubsection{Measures}

The experimental and control group received postal questionnaires at three time points: a pre-test right before the start of the course ( 0 ), a post-test directly after finishing the course (t1) and another three months after termination (t2). The target population was confined to older adults up to 79 years of age, as they could be expected to be capable of filling out the postal questionnaires without problems. Attitude, perceived social influence, self-efficacy, social participation, social support and wellbeing were operationalized in the questionnaires as follows. Attitude was measured by five items, forming a scale of negative and positive opinions about growing older, for example 'as an older adult one feels that every day is the same' $(\alpha=0.64)$. Perception of the societal opinion on the position of elderly in society was measured by one item: 'older adults have a too little say'. Self-efficacy in starting new activities was measured using the Dutch version of the validated general self-efficacy scale. ${ }^{26,27}$ This scale measures self-efficacy expectations across a variety of situations and consists of two components: initiation and persistence of behaviour, and efficacy in the face of adversity. The scale consists of 16 items, e.g. 'when I decide to do something, I go right to work on it' $(\alpha=0.83)$. Social participation was measured by having the respondents rate the number of hours per week spent recently on hobbies and activities with other people, outside the home. This question was not asked at $t 1$ because of the possible interference of course participation. Social support was measured using the validated scale of perceived everyday support, consisting of ten items like 'do you feel that attention is being paid to you?' $(\alpha=0.88) .{ }^{28}$ Wellbeing was measured using a short version of the validated Dutch scale for wellbeing of the elderly ( 8 items). ${ }^{29}$ The scale measures negative and positive feelings, experienced by the respondent, e.g. 'on the whole I am satisfied with myself' ( $\alpha=0.81)$. Subjective health was assessed by answering a question in which respondents could rate their health from 1 (very bad) to 10 (very good). 
Some sociodemographic characteristics were asked in the questionnaire at t0: gender, age, marital status and level of last occupation. Physical functioning was measured using the 6-item sub-scale of the MOS Shortform General Health Survey (MOS-20) $(\alpha=0.86){ }^{30.32}$ Data were also gathered concerning locus of control ('to what extent can you influence your own health?') and life-events ('have there been radical changes in your life the last few years?').

\subsubsection{Analysis}

The response rates of the experimental and control group were established. Differences in background characteristics in the experimental and control group were tested statistically using the Chi-square test when variables were dichotomous, and MantelHaenszel test for linear trend when trichotomous. The effect of attending the course was analyzed using repeated measures analysis of variance, with the scores of the outcome measure at $\mathrm{t} 1$ and $\mathrm{t} 2$ as dependent variables, and the score at $\mathrm{t} 0$ as covariate (MANOVA). Membership of experimental or control group was the between-subjects factor and time of measurement the within-subjects factor. The between-subjects main effect averaged over $\mathrm{t} 1$ and $\mathrm{t} 2$, and interaction effect were studied. When there was a significant interaction effect $(\mathrm{p}<0.10)$, mean scale scores of the experimental and control group on the outcome measures were assessed seperately at $t 1$ and $t 2$. When an interaction effect was absent, the mean of the scores of the outcome measure at $t$ and $t 2$ was assessed. The scores were adjusted for the initial level of the outcome measure using multivariate regression analysis. Differences in mean scale scores between the experimental and control group and $95 \%$-confidence intervals (95\%-C.I.'s) were assessed. SPSS/PC+ 5.0 was used in the analysis procedures. ${ }^{3.5}$

\subsection{Results}

\subsubsection{Response}

The response rates of people filling out the questionnaire at all three time points were $51 \%$ for the experimental group, and $41 \%$ for the control group. Gender, age and marital status of the response groups did not differ from the originally selected experimental and control group. The experimental and control group did not differ significantly in background characteristics (table 19). Neither did they differ with respect to the initial scores of the outcome variables at to (table 20). These results agree with the assumption that the experimental group ('early' subscribers) did not differ from the control group.

\subsubsection{Effectiveness}

The crude, unadjusted, outcome scores of the pre-test and post-tests are given in table 20. A significant difference of mean scores between the experimental and controlgroup was only found for the outcome of social influence at 12 . A multivariate repeated measures analysis (MANOVA) was used to determine the effect of the course, 
- Table 19. Background characteristics of experimental $(n=71)$ and control group $(n=75)$

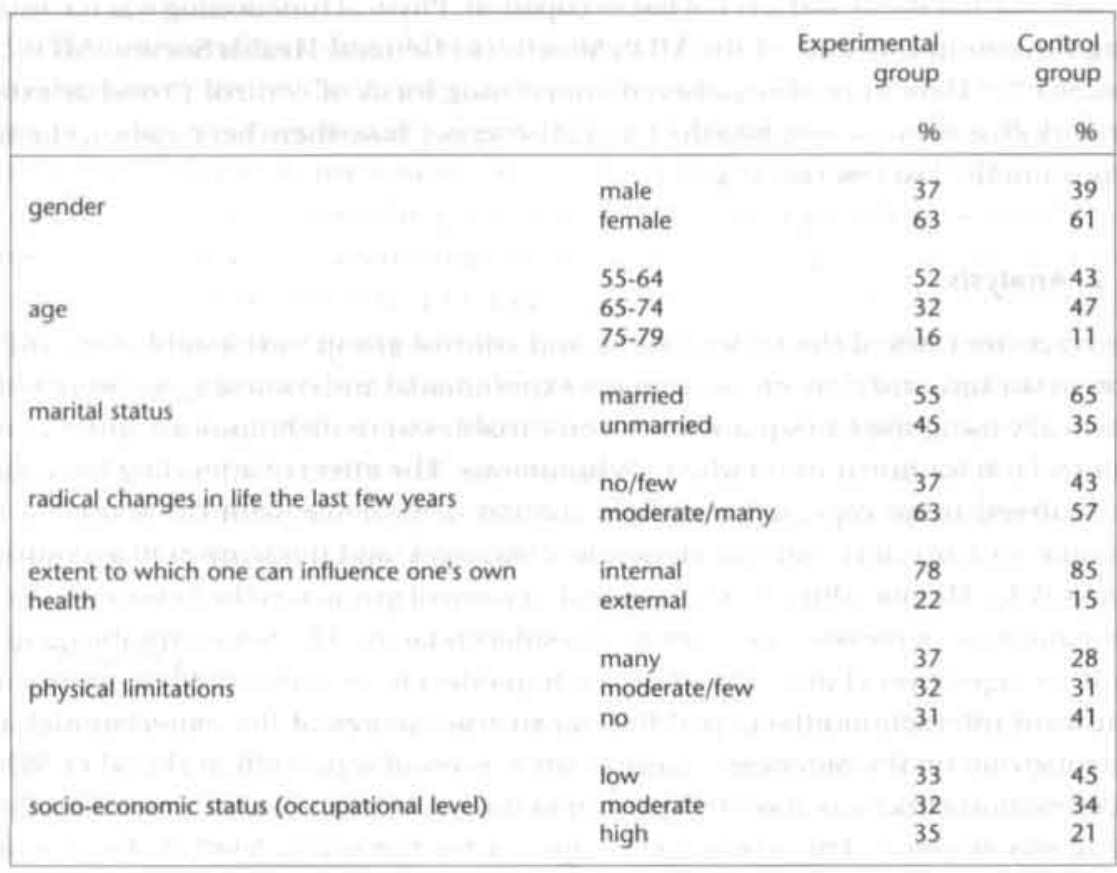

taking into account the initial level of the outcome variable in the pre-test. Interaction between treatment (course membership) and time of measurement was found for the outcome of social influence $(F=9.74, p<0.01)$. The effect was therefore analyzed separately at each time point, however, because of the almost equal pre-test scores of the experimental and controlgroup, the multivariate analysis did not change the results of the crude scores at bivariate level. At $t 1$ immediately after course termination the respondents did not differ significantly with respect to their perception of the societal opinion regarding the position of elderly in society (table 20). After three months ( $t 2$ ) the experimental group compared to the control group disagreed significantly more with the opinion that elderly have little say (difference in adjusted mean scores of 0.55 (95\%-C.I. 0.13-0.96)).

In the repeated measures MANOVA no significant interaction between treatment and time of measurement was found for the other outcome measures. The adjusted scores on the post-tests at $\mathrm{t} 1$ and $\mathrm{t} 2$ are therefore presented in table 20 as group means of the single scores averaged over $\mathrm{t} 1$ and $\mathrm{t} 2$. An effect on attitude towards aging and self-efficacy still was absent, when the pre-test scores of the experimental and control group were taken into consideration. The difference between the experimental and control group in time spent on hobbies and activities with other people outside the home, as an indication of social participation, three months after course termination was also not significant. The course had an effect on the perception of everyday so- 
cial support among its members (a difference in mean averaged scores at $\mathrm{t} 1$ and $\mathrm{t} 2$ of 0.98; 95\%-C.I. 0.05-1.91). The scores of the course members increased from pre-test to post-tests, while the scores of the control group decreased. An effect on general wellbeing was absent, but a clear effect was found on the rating of participants of their subjective health. The course members gave their health at $t 1$ and $t 2$ a mean averaged score of 7.55 , while the score of the control group was 7.18 (difference in mean averaged scores of $0.37 ; 95 \%$-C.I, $0.11-0.63)$ ). Again a rise in mean scores among the course members could be observed against a fall in the control group.

When multiple testing was taken into account ( $\mathrm{p}<0.01$ instead of 0.05 ), the effect on subjective health remained significant at a $99 \%$-confidence interval (99\%-C.I. of mean averaged scores at $t 1$ and $t 2: 0.02-0.72$ ). The effect on perceived social influence at $t 2$ was lost (99\%-C.I. -0.01-1.10). The effect on social support was also no longer significant (99\%-C.I. of mean averaged scores at $\mathrm{tl}$ and $\mathrm{t} 2:-0.25-2.21)$.

- Table 20. Effect of the course: crude and adjusted mean scale-scores and difference in mean scores between experimental and control group (95\%-confidence intervals)

\begin{tabular}{|c|c|c|c|c|c|}
\hline & \multicolumn{2}{|c|}{$\begin{array}{l}\text { Experimental } \\
\text { group (E) }\end{array}$} & $\begin{array}{r}\text { Control } \\
\text { group (C) }\end{array}$ & E-C & $95 \%-C . L^{\prime}$ \\
\hline \multirow{6}{*}{$\begin{array}{l}\text { Interaction time } x \text { treatment } \\
\text { social influence position in society } \\
(1-5) 2\end{array}$} & & M & M & & \\
\hline & to & 2.41 & 2.43 & -0.02 & $(-0.47-0.43)$ \\
\hline & $\mathrm{t} 1$ & 2.39 & 2.61 & -0.22 & $(-0.68-0.24)$ \\
\hline & 12 & 3.05 & 2.51 & 0.54 & $*(0.08 \cdot 1.00)$ \\
\hline & $\mathrm{t}^{3}$ & 2.40 & 2.61 & -0.21 & $(-0.65-0.23)$ \\
\hline & $12^{3}$ & 3.05 & 2.50 & 0.55 & $*(0.13-0.96)$ \\
\hline \multirow{4}{*}{$\begin{array}{l}\text { No interaction } \\
\text { attitude towards aging (5-25) }\end{array}$} & to & 17.78 & 17.45 & 0.33 & $(-1.04-1.70)$ \\
\hline & $\mathrm{t} 1$ & 17.01 & 17.78 & 0.77 & $(-0.53-2.07)$ \\
\hline & 12 & 17.62 & 16.76 & 0.86 & $(-0.55-2.28)$ \\
\hline & $11,2^{*}$ & 17.59 & 16.99 & 0.60 & $(-0.24-1.44)$ \\
\hline \multirow[t]{4}{*}{ generalized self-efficacy $(16-80)$} & to & 59.47 & 60.68 & -1.21 & $(-4.72-2.29)$ \\
\hline & $\mathrm{t} 1$ & 61.32 & 60.53 & 0.79 & $(-3.19-4.78)$ \\
\hline & 12 & 60.47 & 60.20 & 0.27 & $(-3.58-4.12)$ \\
\hline & $\mathrm{t} 1,2^{4}$ & 61.41 & 59.95 & 1.46 & $(-1.07 \cdot 3.98)$ \\
\hline \multirow[t]{3}{*}{$\begin{array}{l}\text { time spent on hobbies and } \\
\text { activities (hours/week) }\end{array}$} & to & 6.55 & 6.93 & -0.38 & $(-2.94-2.17)$ \\
\hline & t2 & 6.61 & 6.61 & -0.01 & $(-2.53-2.52)$ \\
\hline & 12' & 6.75 & 6.48 & 0.27 & $(-1.49-2.02)$ \\
\hline
\end{tabular}


(Table 20 continued)

\begin{tabular}{|llllll|}
\hline social support & $\mathrm{t} 0$ & 31.77 & 32.45 & -0.68 & $(-2.06-0.70)$ \\
& $\mathrm{t} 1$ & 32.36 & 32.00 & 0.78 & $(-1.18-1.90)$ \\
& $\mathrm{t} 2$ & 32.18 & 31.56 & 0.62 & $(-0.83-2.07)$ \\
wellbeing (0-20) & $\mathrm{t} 1,2^{4}$ & 32.54 & 31.56 & 0.98 & $-(0.05-1.91)$ \\
& $\mathrm{t} 0$ & 14.81 & 14.59 & 0.22 & $(-1.40-1.84)$ \\
& $\mathrm{t} 1$ & 14.91 & 14.66 & 0.25 & $(-1.29-1.79)$ \\
subjective health (1-10) & $\mathrm{t} 2$ & 15.44 & 14.49 & 0.94 & $(-0.69-2.58)$ \\
& $\mathrm{t} 1,2^{4}$ & 15.09 & 14.66 & 0.42 & $(-0.43-1.28)$ \\
& $\mathrm{t} 0$ & 7.18 & 7.50 & -0.33 & $(-0.81-0.16)$ \\
& $\mathrm{t} 1$ & 7.42 & 7.25 & 0.17 & $(-0.32-0.65)$ \\
& $\mathrm{t} 2$ & 7.43 & 7.34 & 0.10 & $(-0.35-0.54)$ \\
& $\mathrm{t} 1,2^{4}$ & 7.55 & 7.18 & 0.37 & $\cdot(0.11-0.63)$ \\
\hline
\end{tabular}

\footnotetext{
95\%-confidence interval

scale range

'values of the outcome variables have been adjusted for the initial level at to.

- values of the outcome variables at $\mathrm{t} 1$ and $\mathrm{t} 2$ have been averaged and adjusted for the initial level at to.

- confidence interval does not contain value 0 .
}

\subsection{Discussion}

The effectiveness of the peer-led health education course 'Successful Aging' was evaluated with regard to the following outcome measures: attitude towards aging, perceived social influence, generalized self-efficacy, social participation, social support and wellbeing. Although joining the course is already an act of active aging, assessment of the effects of the course on determinants of participation is relevant in view of the policy aim of motivating older people to become more active. The course is thought to have encouraged people to engage in new (health promotion) activities which should result in an improvement in wellbeing.

This evaluation showed an effect on several outcome measures, however the effect size was small. The course 'Successful Aging' had an effect on the opinion of participants regarding the position of elderly. The experimental group, three months after course termination, showed less agreement with the current societal view (social influence) that 'elderly have a too little say in society' when compared to the control group. Social learning theory indicates that modeling can be viewed as exerting indirect social influence. ${ }^{16,19}$ Education by peers, who act as role models for living an active life, will have contributed to the effect of the importance attached to the elderly. A significant effect on attitude towards aging and generalized self-efficacy could not be found. The course strategies used in the course, consisting of only four sessions, were 
presumably not powerful enough to accomplish an effect. Another explanation may be a 'ceiling-effect'. Participants (and control group) were prepared to join the course, so their initial scores on the outcome measures were already high. Lack of results might also be due to the general nature of the scales used. For instance, the scale used to measure self-efficacy may not have been sensitive enough to monitor the intended change. ${ }^{20}$

The limited effect on the determinants of social participation did not result in a change of activity level, as can be expected from the theoretical model presented in this article (figure 13). The time spent on activities and hobbies with other people outside the home among the experimental and control group did not differ significantly. The course members did not increase engagement in activities that were promoted by the senior health educators, like physical exercise programs, and courses in the field of memory training or dealing with sleeping problems. It should be mentioned that the follow up period during which people could take up activities was very short. Moreover, the follow up took place during the summer vacation period, when many social activities stop in the Netherlands.

The course did achieve an effect on the perception of the daily social support available from the environment. Participation in the course group had influenced social support directly. The group served as a substitute support system for individuals who lacked sufficient informative and emotional support, and because the effect was maintained after three months, the expectations of the social support available in the environment will also have been changed. An indirect influence of course attendance on social support as described in the theoretical model is not plausible because of the absence of an effect on social participation.

The change of perceived social support did not result in an improvement of wellbeing measured by a comprehensive scale, however an effect on the more limited measure of subjective health was present. Directly after finishing the course, and after a lapse of three months, the subjective health valuation of participants changed in a favourable way. The effect on subjective health may have been accomplished by the discussion on health related topics in the course. A study into the characteristics of the older people of Ridderkerk who were interested in participation in the course, showed a lower wellbeing among the interested people compared to the not interested. ${ }^{25}$ Both the experimental and control group were recruited from the older adults who showed interest. Apparently they subscribed to the course in order to work on their health. The need of members of the control group for information and to change their behaviour may explain the decline in perceived social support and subjective health, while they were on the waiting list.

The theoretical model presented in this article is hypothetical, although this study did shed some light on the mechanism of change for wellbeing through participation in a peer-led health education program. A closer study into the determinants of social participation has yet to be undertaken. This evaluation showed that the mes- 
sage of the peer educators to stay active had, after three months, strengthened the course participants in their opinion that society attaches importance to the elderly. The course was not powerful enough to change all determinants of social participation. The experimental group did not take up more activities, however the follow up period of three months may have been too short to show an effect. Other strategies that link up with the course objective of promotion of social participation have to be considered to enlarge effectiveness. For instance site visits to social activities may be added to the course program of 'Successful Aging'. The evidence from the literature on the beneficial effect of social participation on wellbeing could not be confirmed in this study, however a direct effect of the course on social support and subjective health of its members was present. They experienced increased social support and a better subjective health. 


\section{References}

1. Adelmann PK: Multiple roles and psychological wellbeing in a national sample of older adults. J Gerontol Soc Sci 1994;49:S277-S285

2. Kelly JR, Ross J: Later-life leisure: beginning a new agenda. Leisure Sci 1988;11:47-59.

3. Eijk L van: Activity and wellbeing in the elderly. Amsterdam: Thesis Publishers, 1997.

4. Fengler AP: Life satisfaction of subpopulations of elderly. The comparative effects of volunteerism, employment and meal site participation. Res Aging 1984;6:189-212.

5. Havighurst R, Neugarten B, Tobin S: Disengagement and patterns of aging. Neugarten B ed. Middle age and aging. Chicago, London: University of Chicago Press, 1968.

6. Cumming E, Henry W: Growing old. The process of disengagement. New York: Basic Books, 1961.

7. Achenbaum WA, Bengtson VL: Reengaging the disengagement theory of aging: on the history and assessment of theory development in gerontology. Gerontologist 1994:34:756-763.

8. Atchley R: The sociology of retirement. New York: Halsted Press, 1976.

9. Thoits PA: Stress, coping, and social support processes: where are we? what next? J Health Soc Behav 1995; extra issue:53-79.

10. Oxman ThE, Berkman LF, Kasl S, Freeman DH, Barrett J: Social support and depressive symptoms in the elderly. Am J Epidemiol 1992;135:356-368.

11. Hanson BS, Isacsson S, Janzon L, Lindell S: Social network and social suppon influence mortality in elderly men. Am J Epidemiol 1989:130:100-111.

12. Yasuda N, Zimmerman SI. Hawkes W. Fredman L. Hebel JR, Magaziner J: Relation of social network characteristics to 5-year mortality among young-old versus old-old white women in an urban communiry. Am J Epidemiol 1997:145:516-523.

13. Pearson RE: Counselling and social support; perspectives and practice. Newbury Park, London, New Delhi: Sage, 1990.

14. Campbell R. Chenoweth B: Health education as a basis for social support. Gerontologist $1981 ; 21: 619-627$

15. Ajzen I: The theory of planned behaviour. Organ Behav Hum Decis Process 1991:50:179-211.

16. Bandura A: Social foundations of thought and action; a social cognitive theory. Engelwood Cliffs NJ: Prentice Hall, 1986.

17. Vries $\mathrm{H}$ de, Backbier E, Kok G], Dijkstra M: The impact of social influence in the context of attitude, self-efficacy, intention and presious behaviour as predictors of smoking onset. J Appl Soc Psychol 1995;25:237-257.

18. Ajzen I, Madden Th J: Prediction of goal-directed behaviour; attitudes, intentions, and perceived behavioral control. J Exper Soc Psychol 1986;22:453-474.

19. Vries $\mathrm{H}$ de, Dijkstra M, Kuhlman P: Self-efticacy: the third factor besides attitude and subjective norm as a predictor of behavioural intentions. Health Educ Res 1988:3:273-82.

20. Maibach E, Murphy DA: Self-efficacy in health promotion research and practice: conceptualization and measurement. Health Educ Res 1995:10:37-50.

21. Grembowski D, Patrick D, Diehr P, Durham M, Beresford S, Kay E, Hecht J: Self-efficacy and health behaviour among older adults. J Health Soc Behav 1993:34:89-104. 
22. Abler RM, Fretz BR: Self-efficacy and competence in independent living among oldest old persons. J Gerontol B Soc Sci 1988;43:S138-143.

23. Rodin J. MeAvay G: Determinants of change in perceived health in a longitudinal study of older aduls. J Gerontol Psychol Sci 1992:47:P373-384.

24. Rogers EM: Diffusion of innovations. 3d ed. New York: Free Press, 1983.

25. Kocken PL, Voorham A]: Interest in participation in a peer-led senior health education program. In press.

26. Sherer M, Maddux JE, Mercandante B, Prentice-Dunn S, Jacobs B, Rogers RW: The selfeefficacy scale: construction and validation. Psychol Rep 1982;51:663-671.

27. Bosscher R, Laurijssen L, Boer E de: Competentie op later leeftijd; een exploratieve studie. Bewegen \& Hulpverlening 1992;9:255-265.

28. Sonderen E van: Het meten van sociale steun. Groningen Dissertation, 1991.

29. Linschoten CP, Gerritsen JC, Romijn CL:- De Schaal Subjectief Welzijn Ouderen nader onderzocht. Tijdschr Gerontol Geriatr 1993;24:57-65.

30. Stewart AL, Ware JE eds: Measuring functioning and wellbeing. The Medical Outcomes Study approach. Durhmam/London: Duke University Press, 1992.

31. Kempen G1jM: Het meten van de gezondheidstoestand van ouderen; een toepassing van een Nederlandse versie van de MOS-schaal. Tijdschr Gerontol Geriatr 1992;23:132-140.

32. Kempen GIJM: The MOS Short-form General Health Survey; single item versus multiple measures of health-related quality of life: some nuances. Pychol Rep 1992;70:608-610.

33. Norusis MJ: SPSS; SPSS/PC+ advanced statistics. Chicago, 1992. 


\section{Chapter 9}

Effectiveness of peer-led senior health education regarding forgetfulness

epidemiological diagnosis

intervention development

effect evaluation 


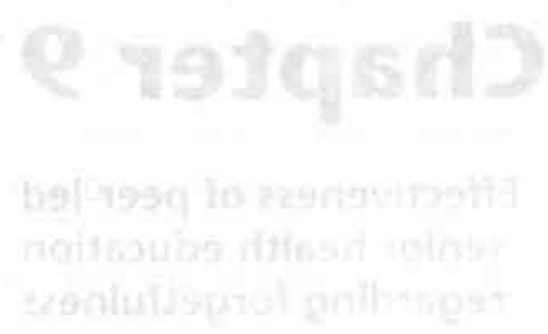

\section{Abstract}

The effectiveness of an education session about forgetfulness aimed at older adults was studied. The session was part of the course Successful Aging. Senior health-educators, aged 55 years and over, were trained to facilitate the course and give information about topics like forgetfulness. The target of the education session was to diminish the anxiety among older adults about normal forgetfulness. The effect on knowledge, attitude, self-efficacy and social influence with respect to anxiety about normal forgetfulness was evaluated. Independent living older adults, aged 55-79, were assigned to an experimental group who attended the course and a waiting list control group. They filled out a postal questionnaire at three time points: before starting the course $(\mathrm{t} 0)$, immediately after termination $(\mathrm{t} 1)$ and three months later ( $t 2$ ). The knowledge about factors relevant to the functioning of the memory had increased among older adults who attended the education session. The education session also had an impact on selfefficacy with respect to how to cope with forgetfulness. An effect on the attitude toward anxiety about forgetfulness and the social influence concerning a taboo on talking about forgetfulness was not found. 


\section{Effectiveness of peer-led senior health education regarding forgetfulness}

\subsection{Introduction}

Older adults have more complaints about forgetfulness than younger people. Older adults seem to perform more poorly on memory tests, however level of education, IQ and health situation modify the relationship between age and memory performance.' One explanation for the poorer memory performance in older adults is among others a more limited information processing capacity of the memory. Moreover, older adults are assumed to use less effective memory enhancing strategies, like organizing information or using visual mediators, which may cause slower retrieval of information. ${ }^{1-3}$ The reduced memory performance level may arouse anxiety and fear of dementia, whereas forgetfulness does not necessarily announce dementia. Forgetfulness is most of the times a normal phenomenon and, although a nuisance, does not need to be alarming.

The effect evaluation of an education session about normal forgetfulness is described in this article. The education session was part of the course Successful Aging, aimed at older adults. The course was facilitated by peer educators, called senior health educators, aged 55 years and over. The aim of the session was to diminish anxiety about forgetfulness among older adults. The following determinants of behaviour were influenced: knowledge, attitude, perceived self-efficacy and social influence. ${ }^{47}$ The difference between normal forgetfuiness and dementia is often poorly understood among older adults. ${ }^{8}$ Improvement in knowledge of factors relevant to the working of the memory may contribute to the reduction of anxiety. Moreover, the behavioural model of this article includes attitude as determinant of behaviour. ${ }^{7,9}$ A change of attitude toward being worried about forgetfulness may play a role in reducing anxiety. The literature shows an association between confidence in memory skills and anxiety about the functioning of the memory. ${ }^{10-13}$ The memory will be used poorly if a person has little confidence in remembering a word, name or face. This confidence in the capability to realize a desired behaviour is called self-efficacy. ${ }^{5,14}$ Social influence as a determinant of behaviour is defined as the processes whereby people, directly or indirectly, influence the thoughts, feelings and actions of others. ${ }^{15}$ People can get disturbed and ashamed when forgetfulness is believed to be a forerunner of dementia. Older adults may keep symptoms of forgetfulness quiet, because of the tabooed nature of the subject in society. ${ }^{16}$ It was expected that older people's worry will decrease, if they changed their expectations regarding openness to talk about forgetfulness with family or friends.

Previous research into the effects of public information meetings about forgetfulness and dementia showed increased knowledge and decreased concern among the audience. ${ }^{\mathrm{X}, 17}$ Evaluation of the effects of health education on determinants of anxiety about forgetfulness is lacking. This article fills up this gap. The following research question was addressed: What was the effect of the education session dealing with forgetful- 
ness in the course Successful Aging on knowledge, attitude, self-efficacy and social influence regarding anxiety about normal forgetfulness? The contents and methods of the course Successful Aging and the education session are explained briefly below.

\subsection{The education session}

The course Successful Aging was organized by the Rotterdam area Municipal Health Service in the community of Ridderkerk in 1995. The course was guided by senior health educators who had been trained extensively at the Rotterdam Polytechnic. ${ }^{18}$ The aim of the course Successful Aging was to improve the quality of life of older adults. ${ }^{10,20}$ Groups of about 20 older adults met once a week for two hours on four occasions. The senior health educators introduced one topic relevant to individuals facing the aging process per session, followed by a peer facilitated discussion. The older adults could enrol for the course and specify topics of their interest using an answer card. The choice 'Dementia and forgetfulness' was ticked most frequently: $55 \%$ of the returned answer cards. Forgetfulness was discussed during the second session of all six of the courses that were evaluated. The first session started with a general introduction. Determinants of successful aging like social support, healthy lifestyles, sufficient income and self-efficacy were introduced by the senior health educator. The group was free to choose which topic it wanted to discuss at the other two sessions. The following topics were chosen: sleeping problems, housing of older adults, use of medicines, osteoporosis, physical exercise, and growing old in different cultures. The courses were given in easy to reach accommodation at the Ridderkerk organization for elderly welfare.

Factors relevant to the memory were discussed in the session about forgetfulness. among others the importance of taking time to remember things, maintaining good physical health, keeping an interest in things, and coping with stress. Memory exercises were mentioned and a memory training course available for the Ridderkerk population was recommended. The accent was on normal forgetfulness. Dementia was only mentioned to distinguish forgetfulness from serious memory problems. The course members' need for information on dementia was met, only after the senior health educator had made clear that forgetfulness is a normal phenomenon.

The strategy used in the course Successful Aging was peer education. It was expected that the message would be best transferred when the age, beliefs and socio-economic status of the senior health educators and the audience were similar. ${ }^{21}$ The method used was role-modelling. The senior health educators, who were not worried about forgetfulness, who had the skills to practice memory exercises, and who talked about forgetfulness, acted as role-models. The course members made clear to each other that they were not the only people who forget things. This exchange of support may contribute to a decrease of anxiety about memory problems. 


\subsection{Methods}

All independent living older adults, aged 55 to 79 years, in the community of Ridderkerk were invited by direct mail to participate in the course Successful Aging. ${ }^{22}$ A total of 150 persons were assigned to the experimental group in the order in which the applications were received; 138 applicants eventually participated. The control group was formed by 182 applicants who were given the opportunity to join the course after the research period. It was expected that the experimental and control group would not differ, because the time period for enrolment was short. The experimental and control group received postal questionnaires at three time points: a pre-test right before the start of the course $(t 0)$, a post-test directly after finishing the course (t1) and another three months after termination (t2). The respondents were asked to give consent to being post-tested. Older adults who had not yet replied to the questionnaires were sent letters of reminder after two weeks. Forgetfulness was just one of the topics of the comprehensive questionnaire.

\subsubsection{Measures}

Measures regarding knowledge, attitude, self-efficacy and social influence with respect to forgetfulness were included in the questionnaires. The five items measuring knowledge of forgetfulness did not form a scale as Cronbach's alpha was low (table 22). The scale measuring the attitude toward anxiety about forgetfulness consisted of three items $(\alpha=0.61)$, e.g. 'You have to be worried if you forget a shopping item' (table 23). Self-efficacy was measured using a scale consisting of four items $(\alpha=0.71)$, e.g. 'Would you succeed in calmly taking time to remember things?'. The perception of the social influence of the taboo on forgetfulness was tested using one item, e.g. 'You would be better not to show if you are forgetting things'. The following socio-demographic characteristics were asked: gender, age, marital status, socio-economic status i.e. level of last occupation. ${ }^{25}$ Physical functioning was measured using the 6 -item sub-scale of the MOS Shortform General Health Survey (MOS-20) $(\alpha=0.86) .{ }^{24}$ Data were also gathered concerning locus of control ('To what extent can you influence you health?'), life-events ('Have there been radical changes in your life the last few years?'), and social participation ('Have you been taken part in clubs or hobbies with other people outside home the last six months?').

\subsubsection{Analysis}

Differences in background characteristics and knowledge of forgetfulness between the experimental and control group were tested statistically using the Chi-square test. The effects of attending the education session about forgetfulness were analyzed using repeated measures analysis of variance, with the scores of the outcome measure at $t 1$ and $\mathrm{t} 2$ as dependent variables, and the score at $\mathrm{t} 0$ as covariate (MANOVA). Membership of experimental or control group was the between-subjects factor and time of measurement the within-subjects factor. The between-subjects main effects averaged over $\mathrm{t} 1$ and $t 2$, and interaction effects between group membership and time were 
studied. The mean averaged scores of the outcome measure at $\mathrm{t} t$ and $\mathrm{t} 2$ were adjusted for the initial level of the outcome measure at t0 using multivariate regression analysis. Differences in mean scale scores between the experimental and control group and $95 \%$-confidence intervals (95\%-CIs) were assessed. SPSS/PC+ was used in the analysis procedures. ${ }^{25}$

\subsection{Results}

\subsubsection{Response}

The response rates of people filling out the questionnaire at all three time points were $51 \%$ for the experimental group, and $41 \%$ for the control group. Gender, age and marital status of the response groups did not differ from the originally selected experimental and control group. The experimental and control group did not differ significantly with respect to background characteristics, as was expected (table 21). Neither did they differ with respect to the initial scores on the outcome variables knowledge, attitude, self-efficacy and social influence at to (tables 22 and 23).

- Table 21. Background characteristics of experimental (E) and control group (C)

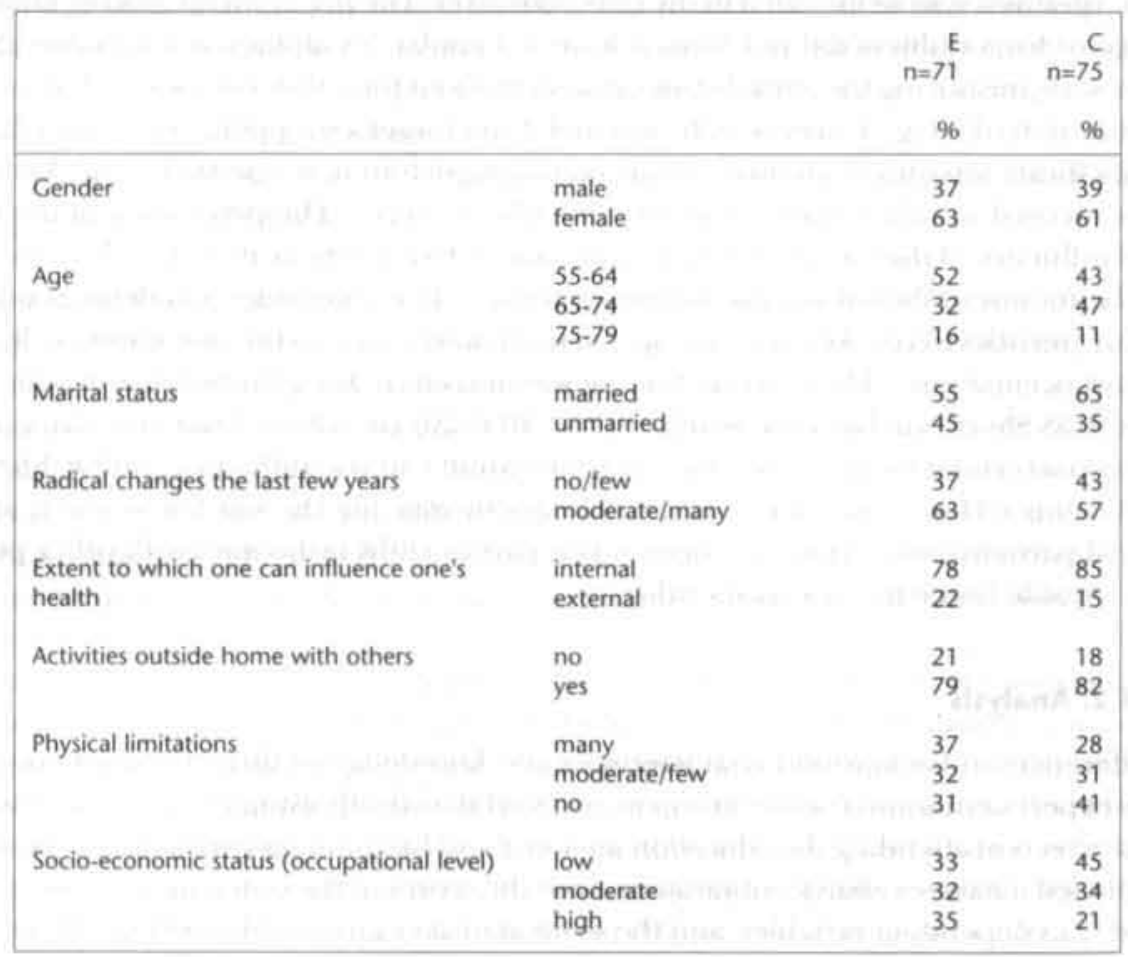




\subsubsection{Effect}

Effects of the education session were found on knowledge about forgetfulness (table 22). The experimental group gave significantly more often the correct answer to the items 'I run great risk for dementia if my memory gets poorer' ( $54 \%$ against $27 \%$ ) and 'depressed thoughts can lead to memory complaints' (42\% against $27 \%$ ), than the control group, right after course termination ( $t 1)$. Moreover, more course participants than non-participants gave the correct answer to the item 'good physical health is important to the memory', three months after course termination $(82 \%$ against $60 \%$ ).

- Table 22. Knowledge of forgetfulness

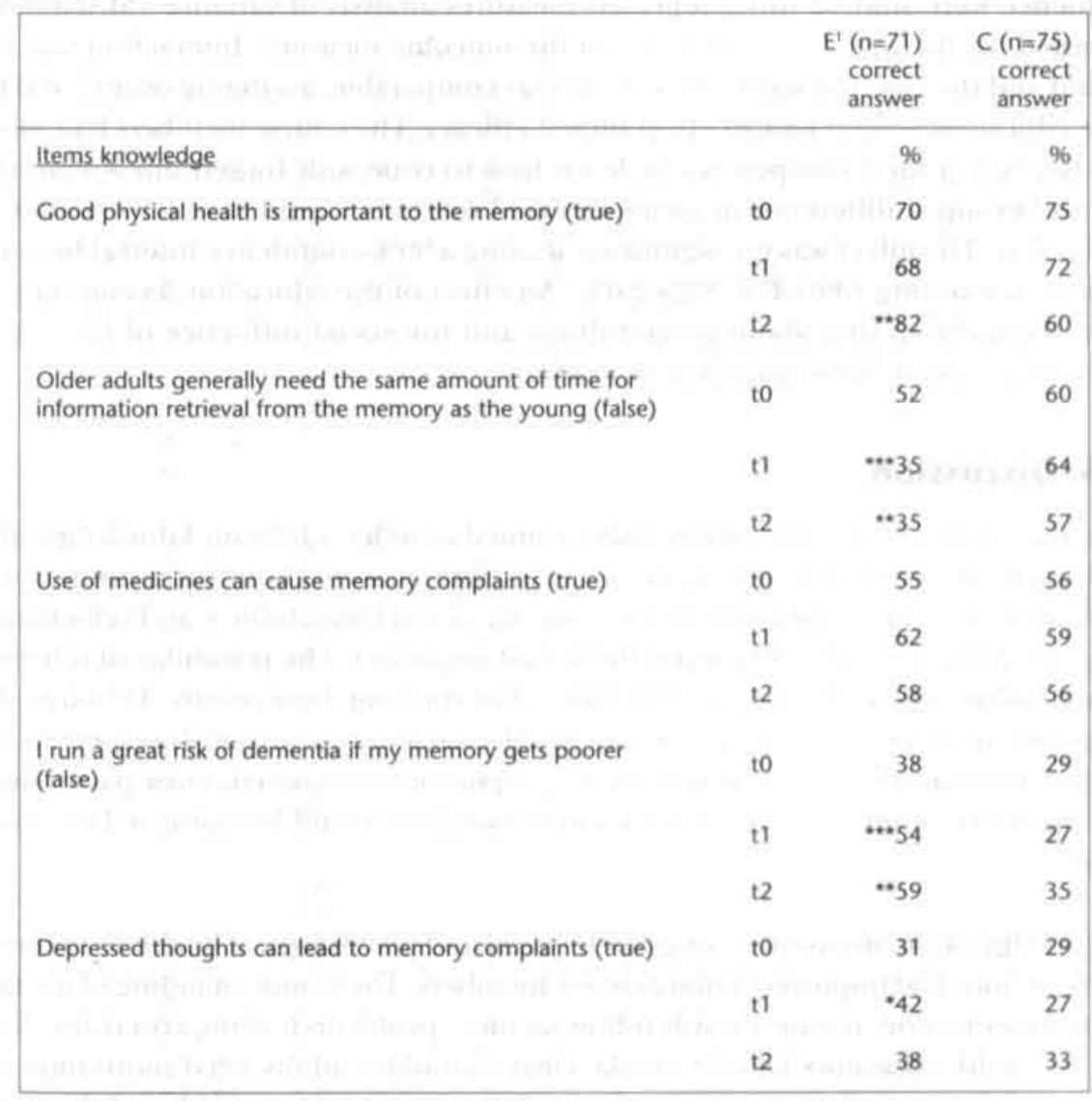

$1 \mathrm{E}=\mathrm{experimental}$ group, $\mathrm{C}=\mathrm{control}$ group

- Chi-square test, $p<0.05$

* Chi-square test, $p<0.01$

*. Chi-square test, $p<0.001$ 
The experimental and control group did not differ significantly anymore at t 2 with respect to knowledge of the effect of depressive thoughts on forgetfulness. Neither did the study groups differ with respect to knowledge of the association between use of medicines and memory complaints at all time points. An unintended effect of the course was found on knowledge of the difference in memory performance between older adults and younger people. Course participants more often were wrongly of opinion that older people perform as well as younger people regarding the retrieval process of the memory; $35 \%$ of the experimental group gave the right answer compared to approximately $60 \%$ of the control group.

Crude, unadjusted mean scores of the items and scales are given in table 23. The interaction effect of group membership and time on attitude, self-efficacy and social influence were studied using repeated measures analysis of variance (MANOVA), adjusted for the initial pre-test score on the outcome measure. Interaction was not found and the post-test scores were treated as comparable, averaging over $\mathrm{t} l$ and $\mathrm{t} 2$. The education session had an effect on self-efficacy. The course members had more confidence in their competence to learn how to cope with forgetfulness than the control group, a difference in mean averaged scores at $\mathrm{tl}$ and $\mathrm{t} 2$ of 0.89 (95\%-C.I. 0.03-1.75). The effect was not significant if using a $99 \%$-confidence interval because of multiple testing (99\%-C.I. -0.24-2.03). An effect of the education session on attitude toward worrying about forgetfulness and the social influence of the taboo regarding forgetfulness could not be proven.

\subsection{Discussion}

The effects of a health education session aimed at older adults on knowledge, attitude, self-efficacy and social influence regarding anxiety about forgetfulness was evaluated. It can be concluded that knowledge about forgetfulness and self-efficacy regarding how to cope with forgetfulness had improved. The possibility of selective loss to follow-up should be considered when interpreting these results. Although the respondents were similar to the originally selected study groups with respect to demographic characteristics, a possibly higher proportion of motivated course participants among the respondents compared to non-respondents could have affected the study results.

Knowledge of the importance of good physical and psychological health to memory performance had improved among course members. Their understanding of the fact that dementia does not necessarily follow memory problems had improved also. The senior health educators failed to make clear that older adults need more time for information retrieval than younger people. The empowerment of older adults, motivating them to stay active and seek new challenges, was emphasized in the course Successful Aging. Older people were approached as individuals who are not inferior to the young. Their poorer memory performance might not have been stressed, which may explain the incorrect answers to the item about memory performance. 


\begin{tabular}{|c|c|c|c|c|c|c|c|c|c|c|}
\hline & t & & 1 & & $t$ & & & $t 1,2^{3}$ & & \\
\hline & $\mathrm{E}^{2}$ & C & E & C & E & c & E. & C & E.C & $95 \%-\mathrm{C} .1$. \\
\hline Attitude & $\mathrm{M}$ & M & M & M & M & M & M' & $M^{3}$ & & \\
\hline You have to be worried if you forget a shopping item $(1-5)^{4}$ & 4.06 & 3.99 & 4.19 & 4.15 & 4.41 & 4.21 & & & & \\
\hline $\begin{array}{l}\text { You have to be worried if you forge: the right word in a } \\
\text { conversation (id) }\end{array}$ & 3.85 & 3.47 & 4.06 & 3.57 & 3.96 & 3.80 & & & & \\
\hline $\begin{array}{l}\text { You have to be worried il you can not remember in the } \\
\text { afternoon the conversation during the morning coffee (id) }\end{array}$ & 2.76 & 2.84 & 3.10 & 2.75 & 2.93 & 2.75 & & & & \\
\hline Scale score $(3.15)$ & 10.65 & 10.28 & 11.35 & 10.47 & 11,38 & 10.76 & 11,26 & 10.72 & 0.54 & $(-0.16-1.25)$ \\
\hline Sell efficacy & & & & & & & & & & \\
\hline Would you succeed in practising memory exercises? (1-5) & 3.69 & 3.88 & 4.02 & 3.91 & 3.90 & 3.89 & & & & \\
\hline $\begin{array}{l}\text { Would you succeed in participating in a memory training } \\
\text { course? (id) }\end{array}$ & 3.88 & 4.09 & 3.95 & 3.81 & 3.89 & 3.80 & & & & \\
\hline $\begin{array}{l}\text { Would you succeed in keeping interested in things when } \\
\text { growing older? (id) }\end{array}$ & 3.91 & 3.87 & 3.86 & 3.72 & $4,0.7$ & 3.65 & & & & \\
\hline $\begin{array}{l}\text { Would you succeed in calmly taking time to remember } \\
\text { things? (id) }\end{array}$ & 3.77 & 3.81 & 3.97 & 3.88 & 4.03 & 3.83 & & & & \\
\hline Scale score $(4-20)$ & 15.23 & 15.69 & 15.79 & 15.31 & $15.9 \cdot 4$ & 15.20 & 16.01 & 15,12 & 0.89 & $=(0.03-1.75)$ \\
\hline Social influence & & & & & & & & & & \\
\hline $\begin{array}{l}\text { You would be better not to show if you are forgetting things } \\
\text { (1-5) }\end{array}$ & 3.91 & 3.72 & 4.15 & 3.67 & 3.65 & 3.59 & 3.86 & 3.67 & 0.19 & $(-0.16-0.54)$ \\
\hline
\end{tabular}

The group totals differ per analysis because of partial non-response

I. Experimental group, C=control group

$95 \%$-confidence interval

a Averaged scores at $t 1$ en 12 , corrected for the initial scores on the outcome measure in the pre-test ito) wsing multivaniate regresson analysis. 
Research shows the importance of memory self-efficacy expectations as determinant of anxiety about memory performance. ${ }^{10,13}$ The education session had an influence on confidence in the individual's competence to learn how to cope with forgetfulness. The course members felt more self-assured, for example to take time to remember things, although the effect was small. Much attention was spent on selfefficacy with respect to the health related topics discussed in the entire course. The course members were educated to be 'manager of their own existence' in general, which may have influenced their self-efficacy expectations in the field of forgetfulness. The use of senior health educators who were role models, may have contributed to the effect on self-efficacy. The method of modelling is very suitable for improving self-efficacy according to social learning theory. ${ }^{5} \mathrm{~A}$ closer study has to be conducted into the working of role-modelling by a senior health educator in comparison to, for example, education by a young nurse.

Knowledge of the absence of a direct relationship between forgetfulness and dementia, which was emphasized by the senior health educators, had improved. An effect on the attitude toward anxiety in situations when memory fails and on the perceived social influence of tabooness with regard to forgetfulness could not be proven. Two hours of education on forgetfulness will have been too short to show effect. It should be mentioned that the behavioural model of determinants of forgetfulness used in this evaluation study is hypothetical and has to be studied more in depth.

The senior health educators drew the course members' attention to the memory training courses available in the community of Ridderkerk. These courses are also aimed at reduction of anxiety about the working of the memory and acceptance of memory complaints. ${ }^{26,27}$ Evaluation studies into memory training recommend attention to memory self-efficacy, in addition to memory-enhancing techniques like memory and concentration exercises. ${ }^{10-12}$ This evaluation study shows that the use of older peers and attention to self-efficacy in the field of memory and also looking at self-efficacy in other fields, is to be recommended for memory training programs. Moreover, a more comprehensive memory training course would make an effect on the attitude and social influence with respect to anxiety about forgetfulness possible. 


\section{References}

1. Huppert FA. Age-related changes in memory: learning and remembering new information. In: Corkin S, Grafman J, Boller F, eds. Handbook of neuropsychology. Volume 5. Amsterdam: Elsevier, 1993.

2. Poon LW. Differences in human memory with aging; nature, causes, and clinical implications. In: Birren JE, Schaie KW, eds. Handbook of the psychology of aging. 2nd ed, New York: Van Norstrand Reinhold, 1985:427-62.

3. Light LL. Memory and aging: four hypotheses in search of data. Ann Rev Psychol 1991;42:339376.

4. Ajzen I. The theory of planned behavior. Organizational behavior and human decision processes 1991;50:179-211.

5. Bandura A. Social foundations of thought and action: a social cognitive theory. Englewood Cliffs NJ: Prentice Hall, 1986.

6. Vries $\mathrm{H}$ de, Determinanten van gedrag. In: Damoiseaux V, Molen HT van der, Kok GJ, red. Gezondheidsvoorlichting en gedragsverandering. Assen: Van Gorcum, 1993: 109-132.

7. Stroebe W, Stroebe MS. Social psychology and health. Buckingham: Open University Press, 1995.

8. Commissaris CJAM. Voorlichting over geheugenproblemen en dementie. [proefschrift]. Maastricht: Rijksuniversiteit Limburg, 1993.

9. Ferrini R, Edelstein S, Barret-Connor E. The association between health beliefs and health behavior change in older adults. Prevent Med 1994:23:1-5.

10. Zarit SH, Gallagher D, Kramer N. Memory training in the community aged: effects on depression, memory complaint, and memory performance. Educ Gerontol 1981;6:11-27.

11. Zarit SH, Cole KD, Guider RL. Memory training strategies and subjective complaints among memory in the aged. Gerontologist 1981;21:158-164.

12. Scogin F, Storandt M, Lott L. Memory-skills training, memory complaints, and depression in older adults. J Gerontol 1985;40:562-568.

13. Ponds RWHM. Bruning HA, Jolles J. Ouderen en geheugenklachten. Een onderzoek naar zelfkennis over het geheugen, depressie en geheugenprestaties. Tijdschr Gerontol Geriatr 1992:23:188-194.

14. Bandura A. Regulation of cognitive processes through perceived self-efficacy. Develop Psychol 1989:25:729-735.

15. Vries $\mathrm{H}$ de, Backbier E., Kok GJ. Dijkstra M. The impact of social influence in the context of attitude, self-efficacy, intention and previous behavior as predictors of smoking onset.J Applied Soc Psychol 1995;25:237-257.

16. Verhey FRJ, Ponds RWHM, Jolles J, Commissaris CJAM. Vergeetachtig? of dement? Bunnik: Alzheimer Stichting, 1992.

17. Commissaris CJAM, Verhey FRJ, Ponds RWHM, Jolles J, Kok GJ. Publiekswoorlichting over normale vergeetachtigheid en dementie: belang en effecten. T Soc Gezondheidsz 1993:71:32-36.

18. Kemme G. Educating senior health educators: report concerning education and emancipation of people in 'the third age'. Rotterdam: Hogeschool Rotterdam \& Omstreken, Gemeentelijke Gezondheidsdienst voor Rotterdam en omstreken, 1995.

19. Voorham AII, Kocken PL, Hofman, HAL, Kemme GH. Seniorenvoorlichting in Rotterdam: uitgangspunten, onderzoek en praktijk. Sanderman R, Heuvel WJA van den, Krol B, red. 
Interveniren in de determinanten van gezondheid: resultaten van cen onderzoeksprogramma. Assen: Van Gorcum, 1995:127-140.

20. Kocken PL, Voorham AIJ. Effects of a peer-led senior health education program. Patient Educ Couns 1998:34:5-14.

21. Rogers EM. Diffusion of innovations. 3d ed. New York: Free Press, 1983.

22. Kocken PL., Voorham All. Interest in participation in a peer-led senior health education program. Patient Educ Couns 1998;34:15-23.

23. CBS. Beroepenclassificatic 1984. Voorburg: Centraal Bureau voor de Statistiek, 1985.

24. Kempen GIJM. Het meten van de gezondheidstoestand van ouderen: een toepassing van een Nederlandse versie van de MOS-schat. T Gerontol Geriatr 1992;23;132-140.

25. Norusis MJ. SPSS; SPSS/PC+ advanced statistics. Chicago, 1992.

26. Nouws A. Een cursus geheugentraining voor ouderen: een eerste beschrijving van opzet, organisatie en mogelijke effecten. T Gerontol Geriatr 1988;19:211-214.

27. Warmelink C, Werkt geheugentraining? De Psycholoog 1990;25:578-581. 


\title{
Chapter 10
}

\author{
Conclusions \\ and discussion
}

epidemiological diagnosis

intervention development

effect evaluation 
or vigisily

moladanoz

molkabain bris. 


\section{Conclusions and discussion}

This thesis comprises a number of empirical studies in support of health promotion in migrants and older adults. The objective of these studies was to contribute to the planned development and provision of health promotion programs, which were carried out by the Rotterdam area Municipal Health Service. Health promotion is viewed in this thesis as a planned combination of educational, facilitative and advocatory activities that enable people to adopt healthy behaviour. The studies illustrate the following subsystems of health promotion planning: epidemiological diagnosis, intervention development and effect evaluation. Interest was in the following aspect systems of health promotion planning: the objects health promotion planning was focused on, and the products of health promotion planning. The processes whereby the products were reached were not the primary interest of this thesis.

The following research question was addressed:

What is the object and product of epidemiological diagnosis, intervention development and effect evaluation in health promotion planning, aimed at migrants and older adults?

The conclusions regarding the objects and products of health promotion planning are given in the first section, and they are arranged per subsystem, i.e. epidemiological diagnosis, intervention development and effect evaluation. Some remarks on the validity of the empirical studies described in this thesis are given in section 10.2. The general implications of the conclusions for the practice of a public health service are discussed in section 10.3. Suggestions for future research are given in section 10.4.

It should be mentioned that the contribution of the studies to intervention development was limited because the programs had already been set in motion at the time the studies started. The studies into the peer-led education programs were part of broader evaluation studies of the effectiveness of the programs. The study into the loneliness intervention program 'In Good Company' described the program in retrospect. The programs were established facts and the studies could be used to contribute to further development of the chosen strategies.

\subsection{The object and product of health promotion planning}

\subsubsection{Epidemiological diagnosis}

\section{Object}

The object of epidemiological diagnosis is the occurrence relation between a health outcome and a determinant (see figure 14). ${ }^{1}$ The health status of two Rotterdam populations was studied in this thesis, i.e. Surinam citizens and older adults. Epidemiology conducted in support of health promotion activities can be characterized as descriptive and particularistic. The epidemiological diagnosis was conducted over a 
limited time period and for specific populations. The health status was described according to background characteristics which did not need to be causal of nature, like gender, socio-economic status or ethnicity. Miettinen calls the epidemiological research into causal relationships between disease and determinants, which can be generalized to the general population, 'scientific', nevertheless the epidemiological diagnosis conducted for administrative purposes to support health promotion planning makes as much use of scientific research methods. ${ }^{1}$

- Figure 14. Subsystems and aspect systems of the health promotion programs described in this thesis

\begin{tabular}{|c|c|c|}
\hline & $\begin{array}{l}\text { Object: what theme or } \\
\text { problem? }\end{array}$ & $\begin{array}{l}\text { Product: which outcomes or } \\
\text { solutions? }\end{array}$ \\
\hline Epidemiological diagnosis & - health outcome - determinant & $\begin{array}{l}\text { - prevalence } \\
\text { - risk groups } \\
\text { - risk indicators }\end{array}$ \\
\hline Intervention development & $\begin{array}{l}\text { - behaviour - determinant } \\
\text { - theories } \\
\text { - diffusion }\end{array}$ & $\begin{array}{l}\text { - targets, learning and } \\
\text { change objectives } \\
\text { - target groups } \\
\text { - methods, strategies, materials } \\
\text { - linkage strategies }\end{array}$ \\
\hline Effect evaluation & - outcome - exposure & - effectiveness \\
\hline
\end{tabular}

\section{Product}

The products of the epidemiological diagnosis in the Surinam and elderly populations were in the field of knowledge of prevalences, risk groups and risk indicators (see figure 14). A cross-sectional design was used, yielding prevalence rates of the health outcomes. The diagnostic studies helped to specify the Rotterdam Surinam and elderly populations as general risk groups, and to indicate subpopulations that were especially at risk. The study into the health of the Surinam population concluded higher mortality among the Surinamese compared to the Dutch. Moreover, Surinam migrants were at risk, in respect to their poorer self-rated health and more frequent use of general practitioners, compared to the Dutch. A closer study into the health of risk groups within the Surinam population, i.e. older age groups and students, was recommended. A deprived health situation also can be found among other immigrant groups in the Netherlands. Subjective health is rated more often as poor by Turks and Moroccans compared to the Dutch. ${ }^{2-4}$ A higher standardized mortality was observed among Turkish and female Moroccan inhabitants, however mortality among Antillian/Aruban and male Moroccan inhabitants was less. ${ }^{5}$

The results of the diagnostic study among Rotterdam older adults, showed a relative higher prevalence of psychosocial problems, compared to older adults in smaller communities. The higher prevalence of psychological problems, compared to relative smaller towns, corresponds with other studies. ${ }^{6,7}$ Several explanations are given for the urbanisation effect on psychological problems. ${ }^{8}$ The living circumstances in big cities, like criminality, losing touch with the neighbourhood and poor social con- 
tacts, can cause psychological problems; people with psychological problems move to big cities; mental health care is better organized and accessible in big cities; and finally, risk groups, like single people and low socio-economic groups, can more often be found in bigger cities.

The following risk groups appeared among the Rotterdam elderly population: women, men living alone, residents of service apartments and groups of low socio-economic status. The risk group of single individuals has been found in several studies. ${ }^{9} \mathrm{~A}$ distinction has to be made between men and women among the elderly. The psychosocial health among elderly women, living alone or not, turned out to be poor. Among men, those living alone were at risk. An explanation for the risk group of the institutionalized elderly is that psycho-social problems are admission criterium for service apartments. ${ }^{10,11}$ The result of low socio-economic groups at risk for poor health has been proven in many studies, including for old age groups. ${ }^{1214}$

Determinants in the field of lifestyles that affect health, like smoking, diet, stress or sexual practices, were not included in the epidemiological diagnosis studies. Strictly speaking these determinants are part of the behavioral diagnosis of PRECEDE-PROCEED. Many of the above mentioned determinants of health are static, unchangeable factors, like age, gender, ethnicity, or physical handicaps, however attention must be paid to static factors which are relevant to indicate risk groups. ${ }^{15}$ The interest of health promotion is in changeable behavioural and environmental factors. Knowledge of the prevalence of adverse lifestyles or environmental conditions is helpful to determine what preventive interventions are useful. Moreover, studying social psychological determinants of behaviour, like attitude or self-efficacy, is even more useful to intervention development. This so called educational diagnosis is placed in this thesis under intervention development and will be described in the next section. The epidemiological diagnosis in older adults included the changeable determinant social support. Support groups, counselling, meeting and leisure activities are among others instruments which affect the obtained social support by individuals. ${ }^{16}$ The study result of a high prevalence of limited social support among Rotterdam elderly provided the reason to start the loneliness intervention program 'In Good Company'. ${ }^{17}$ The study into the health of Surinamese immigrants was not followed by an intervention, apparently because changeable determinants were not studied.

\subsubsection{Intervention development}

\section{Object}

It can be seen from figure 14 that the objects of development of peer-led aids education, peer-led senior health education and the loneliness intervention are behavioural change theories, determinants of behaviour, and diffusion of the intervention. These objects are part of the intervention mapping procedure, which supports the making of decisions during the process of intervention development. ${ }^{18}$ The intervention mapping procedure encourages the development of theory based interventions, meaning that interventions are built on theories which explain behavioural change. 
The Health Belief Model was used in the peer-led AIDS education program. ${ }^{19,20}$ The peer-led senior health education program was based on the ASE-model. ${ }^{21}$

The diagnosis of determinants of behaviour is viewed in this thesis as part of intervention development. The determinants of condom use among Turkish and Moroccan men were studied. The senior health education program was grounded in theoretical or hypothetical models that explain behaviour. Empirical evidence of the applicability of these models to older adults was absent. A closer study into the determinants of social participation or anxiety about forgetfulness is recommended.

The diffusion of an intervention is an underestimated activity of intervention development. Disregarding the importance of systematic communication and implementation of the intervention among the target group can be one of the reasons for a program to be ineffective. Paying attention to diffusion should keep pace with the design of the health promotion program from the very beginning. ${ }^{22,18}$ The diffusion steps, dissemination and adoption were objects of the study into the expressed interest to participate in the course 'Successful Aging' among older adults. Moreover, diffusion of the loneliness intervention program 'In Good Company' was study object, when focusing on satisfaction with the strategies of linkage of needs and preferences of program users and program designers.

\section{Product}

The products of intervention development that were studied in this thesis were specification of program targets, identification of determinants of behaviour, differentiation of target groups, assessment of the adoption of the intervention by target groups, and satisfaction with strategies to link program plans and needs of intermediate target groups (figure 14). The studies supporting intervention development made decisions on program objectives, target groups and diffusion more transparent, which ameliorated the programs' quality.

A study was carried out into the objectives that were pursued in the AIDS-education practice of the peer-led program among Turkish and Moroccan men. Moreover, determinants of the behaviour to use condoms were analyzed. The specification of targets and determinants helped to make the program aims more explicit and to indicate target groups. The study into the interest to participate in the course 'Successful Aging' of the peer-led senior health education program was aimed at assessment of the adoption of the course by target groups and identification of groups whose recruitment need special attention. The interest to participate was the endpoint of the dissemination and adoption process. In total $5.8 \%$ of the older adults aged 55 to 79 years, showed interest in the course. The motives of those who decided not to participate were not studied and need further examination, for example barriers to entering a course, but also barriers to the adoption of healthy lifestyles and the stage of behavioural change.

Explicit involvement of target groups in the development of the peer-led health education programs was recommended to allow for the needs of the target groups and 
enhance their participation. The diffusion of an intervention is best warranted, when potential users are involved in the intervention development process, starting with an elaborate assessment of their needs. This linkage of program plans and users' needs is a matter which asks for paramount attention in health promotion. The study into 'In Good Company' showed a development from use of top down, instrumental linkage strategies to democratic linkage of the interests and needs of local intermediates and the city program developers. The satisfaction of the local intermediates with the program increased with the growing use of democratic linkage strategies, i.e. needs assessments, formulation of an action plan by local intermediates, and true two-way communication between program users and developers, which offered prospects for program continuation.

\subsubsection{Effect evaluation}

\section{Object}

The effectiveness of peer-led health education aimed at migrants and older adults was evaluated. The evaluation studies can be characterized as quantitative, summative, product evaluations, using experimental designs. The educational intervention was considered effective when program targets were attained. The intervention's learning objectives were the objects of the effect evaluations, i.e. the determinants of behaviour mentioned above.

\section{Product}

It can be seen from figure 15 that the peer-led health education programs did not affect all learning objectives. The peer-led Aids-education aimed at Turkish and Moroccan men during one session had an impact on the perceived threat of AIDS, i.e. misunderstandings and risk appraisal, however an influence on beliefs regarding condom use was only proven within subgroups. The course 'Successful Aging' of the peer-led senior health education program did not alter all general and health related determinants. An effect on the opinion that elderly have a little say in society (social influence), perceived social support and self-rated health was proven.

An influence of the senior health educator as a role model on self-efficacy and social influence could be expected from social learning theory. The study into the peer-led senior health education project showed some evidence of the effect of social learning. The empowerment of target groups is an attribute of peer education, giving them confidence in their capability to change their situation or behaviour. ${ }^{23}$ An effect of the course 'Successful Aging' on the influence of the societal opinion that the elderly have a little say, was found. At the end of the course participants had a more positive opinion of the influence of the elderly in society. Moreover, their belief in their competence to deal with forgetfulness had improved. An empowering effect, though small, may be concluded.

Several studies have reported on the effects of peer education on health-related behaviour. Two review articles have reported the positive contribution of peer education 
strategies to AIDS prevention in youth, gay men, injecting drug users and prostitutes. $^{24,2}$ The effectiveness of drug abuse prevention, using peer-led education, has also been established. ${ }^{25}$ Other studies have reported a lack of evidence about what mechanisms of peer education bring about the effects. ${ }^{23,27: 29}$ The unrestricted use of peer education especially in youths has been criticised and even called a religious movement. ${ }^{27}$ The theoretical base of peer education is claimed to be in social learning and diffusion of innovation theories, however little is known about what peer mechanism truly affects people's behaviour. The working of the role modelling concept of the social learning theory in peer education for instance has not been proven yet. Moreover, evidence is needed about the influence of characteristics of opinion leaders. Further research into the effects of peer education is recommended. Comparison with expert-led health education is mandatory.

- Figure 15. Effects of peer-education in migrants and older adults

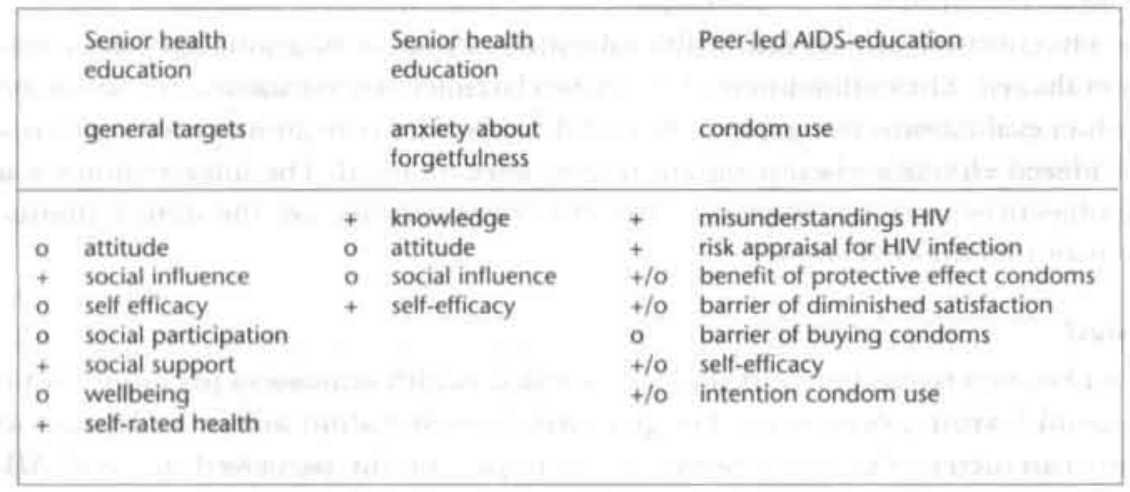

The question whether the products of the effect evaluation of peer education are relevant and satisfactory, can be answered in view of the effect sizes, the evaluation design used and program costs. The change of the outcomes, measured in the evaluation of senior health education, varied from 0.2 times the standard deviation for self-efficacy, and 0.4 for social influence. These should be valued as small to medium effect-sizes. ${ }^{30}$ The behaviour change, i.e. anxiety about forgetfulness and social participation, will be at the most limited, considering these moderate effect sizes and the change of only part of the determinants of behaviours. Moreover, the impact on society will be marginal with a participation rate of $5.8 \%$ in the course 'Successful Aging'.

The effect of the peer-led AIDS education in Turkish and Moroccan men on the perceived threat of AIDS should be valued as medium to large (ORs 5.9 and 2.9) and the effect on beliefs about condom use is small (ORs 0.8 to 1.8), however the effect sizes regarding the beliefs of condom use within subgroups are medium (ORs 2.0 to 3.7). These effects can be viewed as satisfactory, considering the principal aim was to enhance knowledge and awareness of AIDS. Moreover, the effects were reached in 
one shot sessions. The development of strategies to change expectations with regard to condom use in the Muslim communities is a future challenge for the peer-led AIDS education program.

The designs to evaluate the peer-led education programs met practical constraints, contrary to the randomized controlled trial (RCT) design, which can be applied when randomization of individuals is possible. The designs had to adapt to the practice of ongoing interventions. The opportunity to intervene in the intervention practice was limited. The subscription to a course in the real life setting of elderly organizations, or attendance in a mosque or cafe, bounded the inclusion of individuals in the study populations. The 'noise' in these non-selective populations will obscure the effectiveness found. The control of the variation between study groups through the measurement of potential confounders to reduce error variance, will probably not be achieved maximally. ${ }^{31}$ The observed effectiveness will be less than the theoretical efficacy, measured in a laboratory situation.

It can be argued that the costs of the peer-led programs are relatively low compared to personal education by professionals, although a cost-effectiveness study was not conducted. The potential widespread reach among the target population, added to the low costs, is an important rationale for using peer education strategies. ${ }^{23,28,32}$ The peer-educators worked on a free-lance base and were paid for the hours spent on the sessions or courses. With relatively little effort the senior health educators reached about 150 elderly inhabitants of a community in Rotterdam area over six courses, and the migrant peer-educators educated about 1000 immigrants in four cities over 48 sessions. The coordinating professionals who provide a sustaining role for the educators are the most costly, however their contribution is vital to the development and effectiveness of the programs.

\subsection{Validity}

A distinction was made in chapter 1 between internal and external validity. Internal validity is the degree to which the results are correct with respect to the population under study. External validity refers to the generalizability of the results to populations, that were not included in the study population. ${ }^{33}$

\subsubsection{Internal validity}

The designs used in the empirical studies of this thesis are cross-sectional and experimental in nature. The internal validity of the cross-sectional studies will be discussed first.

\section{Cross-sectional studies}

A drawback of the cross-sectional designs of the epidemiological diagnosis studies is the observation of determinants and outcomes at the same time point. A causal influence of the determinant cannot be concluded, however the cross-sectional design 
will do to assess the spread of determinants in the target-populations of health promotion programs. The difference in distribution of potential confounders among the study groups was controlled for in the statistical analysis. To compare mortality among the Rotterdam Surinam and Dutch populations, the mortality among the Surinamese was standardized indirectly, applying the age-specific mortality rates of the Dutch standard population to the age distribution of the Surinam index population. These Standardized Mortality Rates (SMRs) are more stable than Comparative Mortality Figures (CMFs), because the mortality rates of the, normally larger, standard population fluctuate less across the age groups, than those of the index population. ${ }^{3}$

Recall bias has to be considered with respect to questions included in the cross-sectional surveys about, for instance, use of health care services during the last three months or five years. The study into the judgement of intermediates about the 'In Good Company' program, 20 months after the start in their neighbourhood, was also liable to recall bias.

\section{Experimental studies}

Dangers to the internal validity of experimental studies are incomparability of populations, effects and information, which were mentioned in chapter 1 . The following solutions to meet these threats were included in the experimental designs of this thesis.

\section{Incomparability of populations}

The senior health education program was evaluated, using a quasi-experimental design. Randomization of members of the course 'Successful Aging' was not possible. The course was organized by a local welfare organization and the start of it could not be postponed until the entrance procedure was finished. Inclusion into the experimental group was in the order in which the applications were received. The control group was recruited from older adults on the waiting list. The study groups turned out to be comparable with respect to population characteristics. Randomization of study subjects was also not possible when evaluating the peer led AIDS education program. The localities in which the education took place were randomized instead. The confounding effect of an unbalanced distribution of subjects' characteristics among the study groups was controlled for using statistical analysis techniques.

\section{Incomparability of effects}

A theoretical solution to the incomparability of effects is the assignment of the control group to a placebo intervention. A placebo intervention was not included in the evaluation designs presented in this thesis. The control group was not exposed to a substitute intervention, to control for the confounding effect of, for instance, the attention a person gets from the educator, which is, from a parsimonious point of view, not part of the treatment of the education setting. The attention a person gets was regarded as part of the intervention, which agrees with the pragmatic attitude toward evaluation studies instead of explanatory trials. ${ }^{35}$ 


\section{Incomparability of information}

The experimental studies gathered in this thesis, are subject to information bias. For instance, the problem of 'testing' has to be considered, when study groups fill out the same questionnaires at different time points. The subjects may have become 'testwise' as a consequence of completing a pre-test, however both the experimental and control groups received the same questionnaires. ${ }^{36}$ The testing effect will be levelled out as it is indifferent for the experimental and control group. The theoretical remedy of 'blinding' the researcher to control for information bias, was not usable in the real life settings of the evaluation studies. Moreover, 'blinding' the study subjects using a placebo intervention, was not necessary as was mentioned above, considering the pragmatic character of the evaluation studies.

\subsubsection{External validity}

External validity applies to the generalizability of study results. Samples were drawn from the study populations for the cross-sectional studies. Representativeness of the response groups was reached in most studies. The representativeness of the population of the study into the interest of older adults in the course 'Successful Aging' was realized using a weighting procedure. The epidemiological diagnosis studies were particularistic in nature as mentioned above, sustaining the decisions on and development of potential health promotion activities. The possibility to generalize the conclusions to other populations than the study population was considered. The epidemiological study into the health of the Rotterdam Surinamese only applies to Surinamese of Dutch nationality, the great majority of the Surinam immigrants in the Netherlands. It is plausible that the results are applicable to all Surinamese of Dutch nationality in the Netherlands, as most Surinam immigrants live in the big cities of the Netherlands. This assumption is supported by the comparable mortality rates from a study into national census data. ${ }^{37}$

The epidemiological diagnosis study into the psycho-social health of older adults found higher prevalence rates of psycho-social problems among Rotterdam inhabitants, compared to studies in smaller Dutch cities. Generalizability of study results is therefore limited and at best applicable to cities of the same size as Rotterdam. Turkish and Moroccan men with a low educational level were underrepresented in the study population of the educational diagnosis of determinants of condom use. This study is therefore not applicable to low socio-economic groups. The conclusions of the study into the characteristics of older adults who showed interest in participation in the course 'Successful Aging' may be limited to communities in urban areas, with a magnitude of approximately 50,000 inhabitants. The results of the 'In Good Company' program, though a case study, will be illustrative for many health promotion programs. The bottom up - top down controversy is a general problem in health promotion planning.

The effect evaluation studies took place in real life settings, instead of laboratory situations, which enhances their external validity. An indication was derived of the effects 
of peer-led health education under conditions in practice, which is called the 'effectiveness' of a program..$^{36}$ Information on the maximum effects or efficacy of the education programs, which will be found in situations adapted to the demands of randomized controlled trials, is not available.

The studies presented in this thesis taken together are a good example of the health promotion activities of a present day public health service. The studies are not only of importance to the area of Rotterdam, the region of the public health service under which administration the programs took place, but also to other Dutch regions. Senior health education and peer-led AIDS-education for instance are activities available in a number of regions. The financial aid from national funds that made the evaluation studies possible, mark the national importance of the studies included in this thesis.

\subsection{Implications for health promotion at the local level}

The objects and products of the health promotion activities, studied in this thesis, are an illustration of the actual state of health promotion planning in public health services. The following five recommendations are given for the future of health promotion at the local level.

1. The planning of health promotion programs can depart from different starting points, though all planning subsystems should be included for the programs to be successful.

2. Behaviour and its determinants should, if possible, be the object of regular surveys.

3. Target groups have to be involved in program development at an early stage.

4. The linkage of health promotion strategies and materials with theories and methods has to improve.

5. The program designers' concern with criteria for program effectiveness has to increase.

\subsubsection{Recommendations}

The planning of health promotion programs can depart from different starting points, though all planning subsystems should be included for the programs to be successful

This thesis adheres to the definition of planning comprising gaining insight, making decision and taking action. A definition in which planning is described from stage to stage was deliberately not chosen. The planning process is viewed as iterative, going back and forth through the subsystems. This means that the planning of health promotion programs can depart from different starting points. This thesis includes 
program histories, starting from intervention development or epidemiological diagnosis. The programs had to go through a needs assessment, intervention development procedure and evaluation study to reach a successful end.

Conducting an epidemiological diagnosis was the initial activity with respect to the Surinam population, however this did not lead to an intervention. The earlier mentioned absence of changeable lifestyles in the epidemiological study may explain the lack of subsequent health promotion actions. Several studies showed a favourable economic and health situation among the Surinamese, compared to other minority groups like Turks or Moroccans, although their situation was still behind compared to the Dutch. ${ }^{395}$ This argument was used for leaving out the Surinamese as distinct target group for health promotion activities in the Municipal Health Service Rotterdam area.

The starting point of the peer-led AIDS-education program was the development of the intervention. The program was built, in the first instance, on practical knowledge and experiences regarding migrant education. Epidemiological figures on the incidence of STDs among immigrant populations and information about risk behaviours became available after the onset of the peer-led AIDS education program. ${ }^{40-14}$ The studies described in this thesis gave insight into program objectives and program's effectiveness.

The health promotion planning subsystems epidemiological diagnosis, intervention development and effect evaluation were conducted successively in the target group of older adults. The epidemiological diagnosis study showed little or no social support among the elderly and preceded the 'In Good Company' program and peer-led senior health education program. These programs were aimed among others at promotion of social participation in older adults. Both programs were evaluated with respect to their process or effect.

\section{Behaviour and its determinants should, if possible, be the object of regular surveys}

The primary interest of the health promotion worker, involved in designing an intervention, is in the determinants of the behaviour that have to be modified. The epidemiological surveys that are conducted at a regular base in public health services often include comprehensive measurement of health outcomes and limited measurement of behaviour. Measurement of determinants of behaviour is lacking. An epidemiological, behavioural and educational diagnosis together in one survey would be the ideal situation. Asking for determinants could be premature when a decision on what behaviour has to be changed has not yet been taken, however the inclusion of measures of determinants of behaviours in epidemiological surveys should be considered, when there are signals pointing to certain behaviours that induce health problems. For instance, an epidemiologist should not be satisfied when studying the prevalence of smoking alone as a predictor of disease, but should also include questions about the stages of change and determinants of quitting smoking in the survey. 
Conducting a separate survey into behaviour and its determinants among the target group of a specific health promotion program at its start, is of course also possible. An educational diagnosis often is omitted at the time of intervention development, because the intervention has to be developed under great time pressure. When there is little time, a qualitative analysis of determinants is advised, using for instance, focus group interviews among representatives of the target population. ${ }^{45}$

\section{Target groups have to be involved in program development at an early stage}

The involvement of the target group is essential for intervention development. The 'In Good Company' program showed higher satisfaction among intermediates when democratic linkage strategies were used. The investigation into the senior health education program recommended tighter involvement of representatives of older adults, to enhance program participation. Moreover, involvement of target groups in developing new strategies for AIDS education for immigrants was advised. Involvement of the peer educators in intervention development is not enough to tailor the program to the needs of the actual target group. The adaption of a program by offering program users the opportunity to modify an intervention to fit their needs can be viewed as re-invention, a concept from the diffusion of innovations theory. ${ }^{46}$ This means that needs assessment and intervention mapping is required at every stage of health promotion program planning. The program designer has to use all available means to secure the linkage of the program to the users' needs, conducting focus group interviews, organizing community advisory boards, writing action plans in collaboration with users etcetera. The program implementer has to enter consultation with the target group to check its needs and to adapt the intervention to its capacities. The health educator has to check with the audience whether the program satisfies their expectations. An impression of the stage of change has to be derived and the message has to appeal to the right determinants of behaviour.

\section{The linkage of health promotion strategies and materials with theories and methods has to improve}

The senior health education and peer-led AIDS education programs were interventions with some history and tradition at the time of the evaluation studies. The linkage between strategies and materials on the one side, and theories and methods on the other, appeared to be specified weakly during the effect evaluation. At what determinants was the condom demonstration of the peer-led AIDS-education aimed? What were the determinants of social participation that had to be altered? Why change anxiety about forgetfulness using peer education? More time should be spent on the definition of learning and change objectives, using intervention mapping. The technique of intervention mapping advises review of empirical findings, use of social psychological and sociological theories explaining behavioural and environmental change, and additional research among the target group, using surveys and focus group interviews. ${ }^{18}$ Public health officers should take more time to brainstorm program strategies and materials. The development of a program from, for instance, determinants from social learning theory, via the method of role modelling to the strategy of peer education and sustaining materials like an audiovisual aid, is a crea- 
tine process. The accent on intercst groups shith in this process from the program designers to the pregram users. Both parties should participate in brainstorming sessions, workshops and the like, to develop a succesvul intervention.

Fffect exaluation can contribute importantly to improvement of the intervention's qualify fors Clarity in kearning and change objectives, target groups, and diffusion stiat= egies is needed, when designing an cvaluation plan. Program designers are forced to think the program plans over to meet the evaluation requirements. In fact, the specification of the objectives of the pecr-led senior health edtication program and pee-led ADS education program, the identification of determinants of condom use, the differentiation of target groups were all byproducts of the effect evaluation studies, conducted into these programs.

\section{The program designers' concern with criterio for program effectiveness has to increase}

One can question whether the raised knowledge and awareness of the damgers of AIDS is a sufficient outcome of the peer-led AIDS education aimed at migrants, or what determinants of anxiety about forgetfulness should be altered in older adulis at the minimum. Health promotion workers' concern with formulating criteria for program effectiveness is little. They should reach consensus on the conditions under which effectiveness is achieved, before the effect evaluation and implementation of the program start. Criteria for program effectiveness can be delineated, when the learn= ing and change objectives are determined explicitly during the intervention development. The grounding of interventions in empirical insights into risk factors of adverse health and theories of behavioural change, provides the evaluator with a causal chain of what brings about health improvement. Change of determinants of behaviour will in the end lead to change of quality of life, however the time allowed for the evaluation study will determine at what level measurement of change will take place. For instance, change of self-efficacy to quit smoking can be ascertained at the short term, reduction of cardiovascular diseases will only be detectable after many years. The ascertainment of short term effects is satisfactory, when the theories on causal factors and the possibility to change human behaviour are correct. ${ }^{49}$

Further research has to be done into linkage of program strategies and program targets, when a program fails to meet effect criteria, and the program should be cvaluated again. If the program has shown to be effective, a shift to formative evaluation methods, like monitoring or registration of program activities can be proposed. ${ }^{50}$ The effectiveness of the peer-led education programs, evaluated in this thesis, is not yet satisfying. The programs only attained part of the targets, further development and effect evaluation of the programs is recommended.

\subsubsection{Conclusion}

It can be concluded that every health promotion planning subsystem has to be paid attention to, irrespective of the stage of the onset of a health promotion program. The anticipation of information needed for the performance of the health promo- 
tion subsystems and adequate use of available information, is to be recommended at every stage of health promotion planning. Information on lifestyles and determinants of behaviour should be gathered, if possible, in surveys. Evaluation criteria for success or failure of the program should be formulated at the start of intervention development. The target groups should be involved in intervention development at an early stage, for instance they should be consulted during the needs assessment. Theories, methods, strategies and materials of health promotion programs should be linked more systematically during the intervention development.

Many pitfalls will be met during the planning process of health promotion interventions. Descriptive epidemiological research into health problems of a community is adequate for health promotion planning, however the absence of identification of risk indicators and risk groups is a pitfall and decisions on the intervenion's direction cannot be taken. Moreover, the choice of the model for behavioural change is very critical to a program's success. Effectiveness will be low when the wrong determinants are aimed at. For example, the health belief model used in the peer-led AIDS education program turned out to be appropriate as for the determinant of perceived threat. The program objectives concerning expectations with regard to the barriers and benefits of condom use were less clearly formulated. Moreover, analysis of determinants showed only a relationship between beliefs about use of condoms and intention to use them within subgroups. The effect of the education program on beliefs about use of condoms was also less clear. Intervention mapping can be used to study the condom beliefs among unmarried and younger Turkish and Moroccan men and state new clear program objectives.

The existence of ongoing health promotion strategies and materials is another pitfall. In practice programs have to link up with the positive experiences of health promotion workers, and it will take considerable effort to modify ingrained habits. For instance, the evaluation study into senior health education recommended incorporation of other strategies above education by peers, that link up with the program objective of promotion of social participation among the elderly.

The collaboration with the target group is another factor essential for a program's success. Giving the users a voice in program development may have the consequence that intial aims have to be redefined, because of lack of interest. The development of the In Good Company program is an example of the need for modification of program aims.

Health promotion science offers a useful tool box to the health promotion officer, working for a local public health service. The intervention mapping procedure is one such a comprehensive planning tool. This thesis makes clear that health promotion at the local level finds a challenge in practicing the art of choosing the appropriate model for behavioural change, moving from existing health promotion strategies and materials to effective programs, and discussing health change with the local population. The following solutions that are discussed in this thesis are examples of how to 
encounter the obstacles to be met on the way in health promotion planning in the real life setting of local public health:

- Cross-sectional designs to conduct epidemiological diagnosis of prevalence of health problems in communities.

- Establishment of program objectives pursued in practice using group interviews with peer-educators.

- Enhancement of program adoption and implementation using democratic linkage strategies.

- Target group segmentation using survey methods.

- Application of theories of behavioural change to local health promotion issues.

- Random assignment of populations to the experimental and control conditions to evaluate effectiveness of health education programs.

\subsection{Implications for research}

Particularistic and scientific epidemiological studies were distinguished in section 1.4.1. This distinction is usable for all research in support of health promotion. Particularistic research applies to a problem which is specific for a certain period of time and place. Scientific research refers to general problems which are relevant for many situations, independent at what time or where the study is conducted.' Particularistic research also has to meet scientific requirements, therefore scientific research is denoted hereafter as 'general research'.

The results of particularistic research are often of direct importance to policy making. ${ }^{33}$ Particularistic research generates data, usable for the planning of health promotion programs. Health outcomes, risk factors, background characteristics, behaviours and determinants of behaviour are described within the target groups. The particularistic research questions that emerge from this thesis for further investigation are given in figure 16. For example, insight into the causes of mortality among the Rotterdam Surinamese, determines what interventions can be developed. Literature review of available theories and methods on change of condom use and group interviews among Turkish and Moroccan male immigrants, enable designers of the peer-led AIDS education program to increase its effectiveness and to tailor the intervention to the target group's needs.

The unravelling of complicated causal determinants of health problems and behaviour, and the mechanism that brings about the effects of peer education are objects of scientific, general research. Research into the general research questions, mentioned in figure 16, gives insight into the theories about mechanisms how to improve 
quality of life, which can be incorporated in programs of public health services at the local level. For instance, knowledge of risk factors of health problems in migrants, other than socio-economic status, is needed. A program has been proposed to conduct research into the influence of genetic factors, experiences in the home country before migration, experiences after migration regarding, for example, discrimination, the process of adaption to a new culture, and the process of migration itself..$^{51.52}$ Another example of a general research question, is further investigation into the confounding effect of physical health and social support on the relationship between psycho-social health in older adults on the one side and satisfaction with housing conditions and the living environment on the other. Understanding the association between living conditions and health produces insight into the environmental factors which should be aimed at in health promotion.

- Figure 16. Research questions emerging from this thesis

\section{Particularistic research questions}

1. What are the causes of mortality among the Rotterdam Surinam men 15-34 years and women 55.74 years?

2. What are the physical and psycho-social health problems of the Rotterdam Surinamese visiting a general practitioner?

3. What are determinants of condom use in Turkish and Moroccan unmarried and young men?

4. What are barriers of dissemination and adoption of a loneliness intervention program in intermediate users?

5. What are barriers for participation among older adults in the peer-led senior health education program?

6. What strategies and materials enhance the effectiveness of peer-led health education with respect to condom use among Turkish and Moroccan male immigrants?

7. What strategies and materials enhance the effectiveness of peer-led health education with respect to social participation and anxiety about forgetfuiness among older adults?

\section{General research questions}

1. What factors explain health problems among migrants in addition to socio-economic status? What are the backgrounds of psycho-social problems among Surinam students and psychiatric problems among Surinam men?

2. What is the effect of prevention of physical disabilities and social support on the psycho-social health in older adults?

3. What is the effect of physical health and social support on the relationship between living conditions and psycho-social health among older adults?

4. What are determinants of social participation in older adults?

5. What are determinants of anxiety about normal forgetfulness among older adults?

6. What is the effect of role modelling by peer educators, compared to non-peers, like young professional health educators?

7. What factors determine the credibility of peer educators compared to professional health educators? 


\section{References}

1. Miettinen OS. Theoretical epidemiology. Principles of occurence research in medicine. New York: Wiley, 1985.

2. Reelick NF, Gilst ECH van, Driel HF van. De gezondheid van Marokkanen in vijf steden. In: Bleeker JK. Reelick NF. De gezondheid van Marokkanen in de Randstad. Rotterdam: GGD Rotterdam e.o., 1998.

3. Uniken Venema HP. Toen ik hier kwam was ik kerngezond; de gezondheid van Turken in Nederland. Proefschrift. Rotterdam, 1989.

4. CBS. De gezondheidsenquéte Turkse ingezetenen in Nederland 1989/1990. Den Haag: Sdu Uitgeverij, 1991.

5. Wersch SFM van, Uniken Venema HP. Schulpen TW]. De gezondheidstoestand van allochtonen. Mackenbach JP, Verkleij H. Volksgezondheids Toekomst Verkenning 1997 II: Gezondheidsverschillen. Maarssen: Elsevier/de Tijdstroom. Bilthoven: RIVM, 1997, 199-223.

6. Hodiamont PPG, Sijben AES, Koeter MWJ, Oldehinkel AJ. Psychiatrische problematiek en urbanisatiegraad. Tijdschrift voor Psychiatrie 1992;34:426-4.38.

7. Dekker J, Peen J, Iping J. Jonghe F de. Urbanisatie en de relatie met pychiatrische opnames. Tijdschrift voor Psychiatrie 1994;36:585-596.

8. Lieshout P van, Schnabel P. Vragen naar GGZ: ondersteunende stukken voor de Nieuwe Nota Geestelijke Volksgezondheid. Utrecht: Nederlands centrum Geestelijke volksgezondheid, 1984.

9. Joung IMA. De relatie tussen burgerlijke staat en gezondheid. Ned Tijdschr Geneeskd 1997:141:277-282.

10. Wimmers WFHG, Buijssen HPJ. Mertens GHM. Welbevinden van ouderen na verhuizing: gegevens van een longitudinaal onderzoek. Nederlands Tijdschrift voor de Psychologie 1987;42:36-44.

11. Wierik MJM te, Frederiks CMA. De hulpbehoefte en opnamewens van positief geindiceerden: cen vergelijking met verzorgingshuisbewoners. Tijdschr Gerontol Geriatr 1990:21:115-123.

12. Stronks K, Mheen H van de, Mackenbach JP. Sociaal economische gezondheidsverschillen. Mackenbach JP, Verkleij H. Volksgezondheids Toekomst Verkenning 1997 II: Gezondheidsverschillen. Maarssen: Elsevier/de Tijdstroom. Bilthoven: RIVM, 1997, 199-223.

13. Pot AM, Deeg DJH. De gezondheidstoestand van ouderen. Mackenbach JP, Verkleij H. Volksgezondheids Toekomst Verkenning 1997 II: Gezondheidsverschillen. Maarssen: Elsevier/ de Tijdstroom. Bilthoven: RIVM, 1997, 105-132.

14. Marmot MG, Shipley MJ. Do socioeconomic differences in mortality persist after retirement? 25 year follow up of civil servants from the first Whitehall study. BMJ 1996:313:1177-1180.

15. Green LW. Kreuter MW. Health promotion planning: an educational and environmental approach. 2nd ed. Mountain View: Mayfield, 1991.

16. Linneman M, Leene G, Bettink K, Schram M. Voermans J. Uit eenzaamheid; over hulpverlening bij ouderen. Houten: Bohn, Stafleu, Van Loghum, 1990.

17. Kocken PL. Psychisch welbevinden op oudere leeftijd. Onderzoek naar de prevalentie van psychische problematiek en preventiemogelijkheden bij ouderen. Rotterdam: GGD Rotterdam e.o., 1991.

18. Bartholomew L.K, Parcel G, Kok G. Intervention mapping; a process for developing theory-and evidence-based health education programs. Health Education \& Behavior 1998;25:245-563.

19. Janz NK, Becker MH. The health belief model: a decade later. Health Educ Quarterl 1984;11:147. 
20. Rosenstock IM, Strecher VJ, Becker MH. The health belief model and HIV risk behavior change. DiClemente RJ. Peterson JL (ed). Preventing AIDS: theories and methods of behavioral interventions. New York: Plenum Press, 1994.

21. Kok G, Schaalma H, Vries H de, Parcel G, Paulussen Th. Social psychology and health education. Stroebe W, Hewstone M. European review of social psychology. Volume 7. Wiley \& Sons, 1996.

22. Kok $\mathrm{G}$. Why are so many health promotion programs ineffective. Health Promotion Journal of Australia 1993;3:12-17.

23. Turner G, Shepherd J. A method in search of a theory: peer education and health promotion. Health Educ Res 1999:14:235-247.

24. Janz NK, Zimmerman MA, Wren PA. Israel BA, Freudenberg N, Carter RJ. Evaluation of 37 AIDS prevention projects: successful approaches and barriers to program effectiveness. Health Education Quaterly 1996;23:80-97.

25. Coleman L.M. Ford NJ. An extensive review of the evaluation of HIV prevention programs. Health Educ Res 1996:11:327-338.

26. Klepp KI, Haiper A, Perry CL. The efficacy of peer leaders in drug abuse prevention.J of School Health 1986;56:407-411.

27. Frankham J. Peer education: the unauthorized version. Br Educ Res ] 1998:24:179-193.

28. Milburn K. A critical review of peer education with young people with special reference to sexual health. Health Educ Res 1995;10:407-420.

29. Rijke B, Vries N de, Peers doen het beter.... Peer-voorlichting bij jongeren. Tijdschr. Gezondheidsbevordering 1995;16:103-116.

30. Cohen J. Statistical power analysis for the behavioral sciences. 2nd ed. Hillsdale: Lawrence Eribaum, 1988.

3I. Cook TD, Campbell DT. Quasi-experimentation; design \& analysis issues for field settings. Boston: Houghton Mifflin. 1979.

32. Ho EE, Waltz J, Ramstack J, Homoki J, Kligman E, Meredith K, Cohen R, Meyskens F. Heafthpeers: a delivery model for health promotion among the elderly. Educational Gerontology 1987; 13:427-436.

33. Bouter L.M, Dongen MCJM van. Epidemiologisch onderzoek; opzet en interpretatie. Utrecht: Bohn, Scheltema en Holkema, 1995.

34. Veling SH], Sturmans F. Standaardisering van morbiditeits- en mortaliteitscijfers en indices. Tijdschr Soc Geneesk 1981;59:271-278.

35. Schwartz D. Lellouch J. Explanatory and pragmatic attitudes in therapeutical trials.J Chron Dis $1967 ; 20: 637-648$.

36. Popham WJ. Educational evaluation. Englewood Cliffs NJ: Prentice-Hall, 1975.

37. Tas RFj. Surinaamse en Antilliaanse bevolking in Nederland, 1 jantaari 1991. Mndstat Bevolk (CBS) 1992;40:6-8.

38. Sturmans F. Epidemiologie: theorie, methoden en toepassing, Nijmegen: Dekker \& van de Vegt. 1982.

39. ISEO. Minderhedenmonitor 1988: etnishe minderheden in Rotterdam: onderzoek verricht in opdracht van de gemeente Rotterdam. Rotterdam: COS, ISEO, 1999.

40. Laar MJW van de, Sleutjes MPM, Postema, CA. Water HPA van de. Sexueel overdraagbare aandoeningen bij allochtone bevolkingsgroepen; een oriēnterend onderıoek. Ned Tijdschr Geneesk 1991: 135:1542-1547. 
41. Hooykaas C, Van der Velde FW, Van der Linden MMD, Van Doornum GlI. Coutinho RA. The importance of ethnicity as a risk factor for STDs and sexual behaviour among heterosexuals. Genitourin Med 1991;67:378-83.

42. Hoek van den JAR, Coutinho RA. Seksueel overdraagbare aandoeningen, HIV en AIDS bij migranten. Ned Tijdschr Geneesk 1994;138:2188-92.

43. Gelder P van, Lamur HE. Tussen schaamte en mannelijkheid; seksuele relaties en beschermingsgedrag onder Marokkaanse mannen. Amsterdam: Het Spinhuis, 1993.

44. Everaert HA, Lamur HE. Alles wat geheim is, is lekker: seksuele relaties en beschermingsgedrag van Turkse mannen. Amsterdam: Het Spinhuis, 1993.

45. Schaalma H. De analyse van gedragsdeterminanten. Damoiseaux V, Molen HT van der, Kok G]. Gezondheidsvoorlichting en gedragsverandering. Assen: Van Gorcum, 1993.

46. Rogers EM. Diffusion of innovations. 3d ed. New York: Free Press, 1983.

47. Schuurman JH. Gezondheidsvoorlichting en -opvoeding. Onderzoek en actie met betrekking tot hart-en vaatziekten, geslachtsziekten en roken. Lisse: Swets \& Zeitlinger, 1983.

48. Haes WFM de, Gedragswetenschappelijk onderzoek ten dienste van gezondheidsvoorlichting en -opvoeding. Lisse: Swets \& Zeitlinger, 1983.

49. Kok, G. Proces- en effectevaluatie van GVO-interventies, TSG 1998;76:284-285.

50. Nutbeam D. Evaluatie van oorzaak en gevolg in gezondheidbevorderingsprojecten; aanpassing van onderzoeksmethoden aan interventiemethoden. TSG 1999;77:15-23.

51. Stronks K, Uniken Venema P, Dahhan N, Gunning-Schepers LI. Allochtoon, dus ongezond? Mogelijke verklaringen voor de samenhang tussen etniciteit en gezondheid geintegreerd in een conceptueel model. TSG 1999;77;33-40.

52. NWO, ZON. Onderzoeksprogramma cultuur en gezondheid. Den Haag: Nederlande Organisatie voor Wetenschappelijk Onderzoek en ZorgOnderzoek Nederland,1998. 


\section{Epilogue}

The process of how health promotion planning comes about was not the primary topic of interest of this thesis, however the inclination to make comments on the process is irresistible when discussing more than 10 years of health promotion work with colleagues. The introduction chapter started with the observation that traces of a planning effort in the daily life of a health promotion worker can be discovered, when looking from a more removed point of view. The health promotion programs described in this thesis went through the subsystems epidemiological diagnosis, intervention development and effect evaluation. It took about 10 years starting with an epidemiological diagnosis of psycho-social problems and finishing with the evaluation of interventions promoting social participation among older adults. The peer-led AIDS education program started in 1989 and was developed using practical information and experiences of migrant education. Information on the incidence of HIV and sexual behaviour among migrants was scarce and this epidemiological and behavioural information became available after the onset of the program. The effect evaluation was finished in 1999 and the insight into program objectives and determinants of condom use contributed to program development. The time span of 10 years again for program planning may be a coincidence, however the organization of the health promotion programs by public health services depends on complex decision making by local gouvernment. Those seeking funds for preventive health have to compete with other public expenditures. Decisions are made step by step. The decision making process should be viewed as incremental and not as rational. ${ }^{1,2}$ It is not 'homo-economicus' who has all the information to weigh the advantages and disadvantages of a complete set of decision options, leading to the programs now available. The decision outcomes resembled former outcomes and on the whole led to planned health promotion activities. For instance, the need to evaluate the effectiveness of peer-led AIDS education was a wish expressed several times by the Rotterdam area Municipal Health Service, and one that was realized at the moment the AIDS fund was willing to pay. The planning duration of health promotion programs developed at universities may be shorter, as they are less dependent on political decision making, once the research means have been secured.

Effect evaluation contributes to health promotion programs' success. ${ }^{3.4}$ It helps the planned decision making on objectives, target groups, methods and diffusion strategies. The designers of the programs studied in this thesis told me several times that the programs benefited from the discussions about the effect evaluation, although they often considered the requirements of evaluation research a nuisance. It should be an ambition to make intervention development a speciality in its own right, independent of effect evaluation. Research methods like literature review, surveys into determinants of behaviour, and focus groups are used at this moment to a limited degree or in an implicit way by program designers. The use of the transparant intervention mapping technique helps to ground the interventions in theory, to set clear targets, to link theories, methods, strategies and materials. ${ }^{3}$ It prevents the evaluator from being put in the situation that program objectives are not clear when the research starts. 
The investigation of particularistic research questions mentioned in section 10.4 is the primary concern of public health services, and the abstract, general research questions should be studied by universities, although the collaborative effort of both parties should be encouraged. In fact, an exchange between practitioners working at public health services and academics working at universities, giving public health services academic status, is proposed. ${ }^{6}$ Such an exchange will contribute to the academic foundation of health promotion practice. Universities can take advantage of such collaboration, as public health services can put forward relevant research questions arising from issues alive in society. Moreover, public health services have the infrastructure to approach study groups. An example of a research question relevant to society is the effectiveness of activities to prevent loneliness. These activities should be tailored to the needs of individuals. One person is prepared to participate in a support group, the other does not want to be labeled as a lonely person and likes to be a member of a choire, a third one is facing major psychiatric problems and is best of with personal counselling. An RCT into the effectiveness of a support group as panacea for loneliness problems would not give an answer to the question of how to organize effective interventions into loneliness, because these interventions do not meet the needs of all the people. The research question has to be transformed into the effectiveness of tailoring activities to the needs of individuals.

Public health services can take advantage of the methodological expertise present in universities. Universities and public health services have to work together to deveiop designs for conducting research in daily life settings. The RCT is the golden standard but difficult to apply in the practice of public health. For example, randomizing people to a loneliness support group or control group is a problem, considering their divergent needs. Randomizing people to a method assessing their needs and accompanying them to activities, or a control group looks more feasible, however in this case a conclusion on the effectiveness of specific activities cannot be drawn. The effectiveness of the total of tailor made activities, irrespective of their character, is studied. Optimal study designs have to be sought that meet the difficulty of applying research designs. Randomization of groups or communities, pre-randomization, observational methods, monitoring of program performance, and qualitative methods are examples of solutions which should be explored by universities in daily public health practice.

The recommendations given in chapter 10 are aimed at improvement of future health promotion practice. They refer to the anticipation of information needed in the planning subsystems, like including determinants of behaviour in surveys and stating effect criteria when developing interventions. The former Rotterdam area Municipal Health Service departments of Health Education, Epidemiology and Health Policy have been combined to form the new department of Health Promotion. Research scientists, health education consultants and policy makers work together in this new, encompassing department. The programs described in this thesis resulted from this merger process. Many improvements have been made, but there are more improvements still to be made. 


\section{References}

1. Vught FA van. Experimentele beleidsplanning; bestuurskundige expedities in de jungle van het planningsdenken. 's-Gravenhage: VUGA, 1982.

2. Lindblom, ChE. The science of muddling through. Public Administration Review 1975:19:7988 .

3. Haes WFM de. Gedragswetenschappelijk onderzoek ten dienste van gezondheidsvoorlichting en -opvoeding (GVO). Lisse: Swets \& Zeitlinger, 1983.

4. Schuurman JH. Gezondheidsvoorlichting en -opvoeding (GVO). Onderzoek en actie met betrekking tot hart- en vaatziekten, geslachtsziekten en roken. Lisse: Swetz \& Zeitlinger, 1983.

5. Bartholomew LK, Parcel G, Kok G. Intervention mapping: a process for developing theory- and evidence-based health education programs. Health Education \& Behavior 1998;25:245-263.

6. Sturmans F. De GGD als academische werkplaats voor de maatschappelijke gezondheidszorg. TSG 1999;77:65-66. 


\section{Summary}

This thesis comprises a number of empirical studies in support of health promotion in migrants and older adults. The objective of these studies was to contribute to the planned development and provision of health promotion programs. Health promotion is defined as any planned combination of educational, political, regulatory, and organizational supports for actions and conditions of living conducive to the health of individuals, groups or communities. Planning is viewed in this thesis as a system encompassing the subsystems, gaining insight, making decisions and taking action. The following subsystems of planning of health promotion were described: epidemiological diagnosis, invervention development and effect evaluation. Moreover, the aspectsystems, object and product were studied. The process of how the planning of health promotion comes about was not studied. The main research question was: what is the object and product of epidemiological diagnosis, intervention development and effect evaluation in health promotion planning, aimed at migrants and older adults?

Planning of health promotion and its subsystems were explained in chapter 1. Health education was distinguished from health promotion. Health education is aimed at learning experiences facilitating voluntary adoption of behaviour conducive to health. The broad definition of health promotion includes changes of both behaviour and environment. Factors in the environment were discussed in thesis, only when they indirectly hinder or facilitate behavioural change. The following four health promotion planning models were described: Green and Kreuter's PRECEDE-PROCEED framework, Roger's diffusion of innovations theory, Bracht and Kingsbury's community health promotion model, and the Intervention Mapping model developed by Bartholomew, Parcel and Kok. The models differ with respect to the accents on the subsystems and aspectsystems of planning. The intervention mapping model is the most encompassing model, as it pays attention to the object, process and product of epidemiological diagnosis, intervention development and effect evaluation.

Epidemiological diagnosis in support of health promotion can be characterized as descriptive and particularistic. The prevalence of health outcomes is studied in a time and place specific population. The intervention development subsystem includes the educational diagnosis of determinants of behaviour. Interventions have to be grounded in theories concerning behavioural change, for example the ASE (Attitude, Social influence and Efficacy) model and theories regarding peer education. Involvement of the target group and intermediates in intervention development is very important. Effect evaluation, using the Randomized Controlled Trial (RCT) design yields the most valid study results, however application of the RCT requirements, i.e. randomization, placebos and blinding, to the evaluation of health promotion programs is not always possible. Randomization of groups or communities, and use of multiple evaluation methods are recommended as alternatives. 


\section{Migrants}

The study into mortality, self-rated health and reported use of health care services among the Surinam citizens of Rotterdam is presented in chapter 2. Mortality data from the registrar's office were analyzed. Excess mortality in the Surinamese, compared to the Dutch, was found. Mortality was higher especially in male Surinamese aged 15 to 34 and female Surinamese aged 55 to 74 . Health status and health care use were analyzed using postal questionnaires sent to random samples of Rotterdam inhabitants aged between 16 and 75 . The results showed that a higher proportion of Surinamese than Dutch respondents considered their health to be poor and went to their general practitioner one or more times, two months prior to the research period, Further research into the health situation and causes of death in the Surinamese was recommended.

The AIDS education program aimed at male Turkish and Moroccan immigrants in the Netherlands was described in chapter 3. The AIDS education was given in the native language of the target group by peers. The aims of the study were to establish the actual program objectives, to examine determinants of condom use among Turkish and Moroccan men, and to make recommendations for program improvement. Program objectives in the field of knowledge of HIV transmission, the risk of getting AIDS, and condom use were established, using qualitative research methods. Registration of 48 education sessions in coffee houses and mosques showed that the most attention to condom use was paid by the Moroccan educators. The Turkish educators stressed knowledge of HIV transmission. Frequenters of coffee houses and mosques filled out a questionnaire before they received the AIDS education, to examine determinants of intention to use condoms. The following predictors of intention were found: misunderstandings about HIV transmission and beliefs regarding the risk of getting AIDS. The barrier of diminished satisfaction with sex if using a condom, and self-efficacy, were predictors of the intention to use condoms among married men and men aged 30 years and above. The continuation of knowledge transfer and change of beliefs with regard to HIV transmission and susceptibility to AIDS were recommended. Ample discussion of condom use during the education session and attention to selfefficacy with regard to condom use among subgroups was advised. A closer study into the motives for condom use among unmarried and younger Turkish and Moroccan men was recommended, considering the absence of a clear pattern of determinants of condom use.

The evaluation study into the effects of peer-led AIDS education on the perceived threat of AIDS and beliefs about condom use is to be found in chapter 4. A comparison was made between the experimental group, which filled out a short questionnaire at the end of the education session, and the matched control group, who participated in the questionaire before they received the AIDS education. The following effects could be established: decrease of misunderstandings regarding HIV transmission and more realistic beliefs about the risk of HIV infection. Beliefs about condom use were changed within subgroups. The perceived benefit of the protective effect of condom 
use was affected in men of 30 years and older, the perceived barrier of diminished satisfaction if using condoms was changed among unmarried men, condom self-efficacy was affected in men who valued peer education as important, and an effect on intention to use condoms was found among Moroccans. Continuation of peer-led AIDS education for immigrants and adaption of the message to the needs of specific target groups was recommended.

\section{Older adults}

The aim of the study presented in chapter $\mathbf{5}$ was to examine the occurrence of psycho-social problems among the elderly in order to plan prevention programs. A questionnaire was sent to a sample of inhabitants of the city of Rotterdam aged 65-79 years living on their own. The results showed that one third of the respondents experienced psycho-social problems. The elderly in Rotterdam seemed to have psycho-social problems more frequently, compared to elderly people in other Dutch cities and to norm scores. Groups at risk were women, men who lived alone, those with a low socio-economic status, and people who lived in apartment buildings. Risk indicators for psycho-social problems were problems with the performance of the activities of daily living (ADL) and household activities (HHA) as well as decreased social support. The relationship between satisfaction with living conditions and psycho-social problems was affected by these risk indicators. Elderly people who experienced both psycho-social and ADL/HHA-problems had visited their general practitioner most frequently during the three months prior to the questionnaire being received. Preventive activities in the field of $\mathrm{ADL} / \mathrm{HHA}$ and social support, aimed at the risk groups for psycho-social problems were recommended.

Intermediates' satisfaction with linkage of program plans and users' needs in the Dutch loneliness intervention program In Good Company (IGC) is presented in chapter 6. The intermediates were volunteers and professional workers in the field of health care and social welfare. The program targets of IGC were prevention and diminishment of loneliness in older people, aged 55 years and over, and improvement of helping and cooperation skills of intermediates. Experiments with different linkage approaches were carried out successively in three neighbourhoods. In the first neighbourhood an instrumental linkage strategy was used and local organizations were asked to carry out a pre-designed program. In the other two neighbourhoods involvement of the intermediates in program design increased, using bottom up, democratic linkage strategies. The intermediates' satisfaction was measured retrospectively, using postal questionnaires. Satisfaction was highest in the neighbourhood where the intermediates were consulted most explicitly and they had a clear voice in the design and organisation of the intervention, using democratic linkage strategies. The needs assessments among older adults and intermediates showed that there was a demand for change in environmental determinants using meeting and recreational activities for older adults, instead of the behaviour oriented support groups and skills courses which had been proven efficacious from research. It is concluded that the use of democratic linkage strategies, like needs assessments, local action plans and two way 
communication between program designers and users, is essential for the successful dissemination of health promotion activities.

The study into the characteristics of older adults showing an interest in participating in a health education course Successful Aging given by peers is described in chapter 7 . Determining the degree of interest in health education is important for assessing the impact on the target-population and evaluating the dissemination strategy. The course was given by senior health educators aged 55 years and over drawn from the peer group. The aim of the course was to empower older adults to participate in society and to promote their wellbeing. Groups of older adults came together to discuss health related issues. Change of behaviour was aimed at, for instance diminishment of anxiety about normal forgetfulness. To determine interest in the course answer cards were sent with a letter of invitation to all independently living inhabitants aged between 55 an 79 in a Dutch community. The rate of expressed interest in the course was $5.8 \%$. Interest was highest among females in the 55-64 age group, the unmarried and those with low wellbeing. Males in the age group $65-79$, females aged $75-79$, those with a lower socio-economic status and the inactive were comparatively less interested. Subscription to the course was distinguished from mere interest in the course. From those who expressed interest, more people of low socio-economic status, with a reduced level of wellbeing, many physical limitations and poor self-efficacy actually subscribed. It was concluded that the health education program had to be continued and that special attention had be paid to groups that showed lower levels of uptake. Involving intermediates from these groups in the course development was recommended.

The effects of the course Successful Aging on social participation, the determiants of social participation (attitude, self-efficacy and social influence), perceived social support, and wellbeing of the participants aged 55 to 79 years are evaluated in chapter 8 . A comparison was made between the experimental group of course participants and the control group of older adults on the waiting list. The respondents filled out postal questionnaires at three time points, before starting the course (t0), immediately after termination ( $\mathrm{t} 1$ ) and three months later ( 2 2). The current idea that elderly occupy a marginal position in society (social influence) found less favour with the experimental group than the control group at $t 2$. The perceived social support and subjective health improved significantly among the course members at $\mathrm{t} 1$ and $\mathrm{t} 2$. No effect was found on attitude, self-efficacy, social participation and wellbeing in the short time span of a three months follow-up. A closer study into the determinants of social participation and inclusion of other strategies that link up with the course objective of promotion of social participation was recommended.

A study into the effectiveness of an education session about forgetfulness is presented in chapter 9. The session was part of the course Successful Aging. The aim of the education session was to diminish anxiety among older adults regarding normal forgetfulness. The knowledge about factors relevant to the functioning of the memory increased among the course members. The education session also had an impact on self-efficacy with respect to how to cope with forgetfulness. An effect on attitude to- 
ward anxiety about forgetfulness and social influence concerning the taboo on talking about forgetfulness was not found. A closer study into the determinants of anxiety about forgetfulness was recommended. Moreover, the inclusion of peers in memory programs and attention to self-efficacy in the field of memory and other fields was advised.

The conclusions regarding the central research question of this thesis on the object and product of epidemiological diagnosis, intervention development and effect evaluation, are presented in chapter 10. The accent of the epidemiological diagnosis in the Surinamese and older adults was too much on the association between static background characteristics, like gender and age, and health outcomes. Only limited attention was payed at changeable determinants in the field of healthy behaviours and life styles. The study into the health of Surinamese immigrants was not followed by an intervention, apparantly due to the absence of changeable determinants. The products of development of the interventions studied in this thesis were, specification of the objectives of the peer-led AIDS education aimed at Turkish and Moroccan men, identification of determinants of condom use, differentiation of target groups, assessment of the adoption of the course Succesful Aging by target groups among older adults, and insight into the satisfaction with strategies to link program plans and needs of target groups. The theoretical determinants of behaviour at which the senior health education program was aimed require to be studied more in depth. It was concluded from the evaluation studies into the effects of the peer-led AIDS education and senior health education programs, that only part of the learning objectives, i.e. change of determinants of behaviour, was achieved. The attained effects were small to moderate, however the 'noise' encountered doing research in daily life, compared to the ideal circumstances of the RCT, and the low costs of use of peers, have to be taken into account.

The studies included in this thesis showed that health promotion planning can start with epidemiological diagnosis, intervention development or effect evaluation, however every subsystem has to be paid attention to, irrespective of the stage of the onset of a health promotion program. The anticipation of the information needed for the performance of the health promotion subsystems and adequate use of available information, is to be recommended at every stage of health promotion planning. Information on lifestyles and determinants of behaviour should be gathered in surveys, if possible. Evaluation criteria for success or failure of the program should be formulated at the start of intervention development. The target groups should be involved in intervention development at an early stage, for instance they should be consulted during the needs assessment. Theories, methods, strategies and the materials of health promotion programs should be linked more systematically during the intervention development. Particularistic and general research can be supportive for the planning of health promotion. Public health services and universities should conduct these studies in close collaboration. 


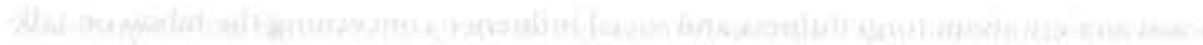

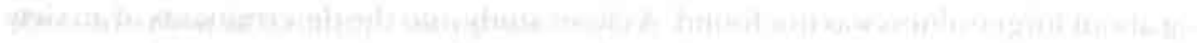

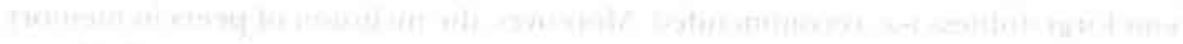

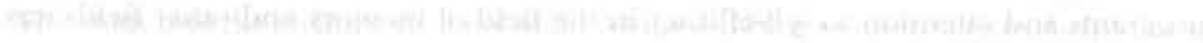
chats and

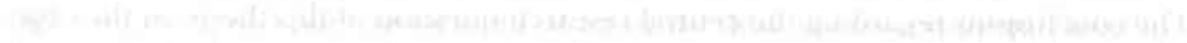

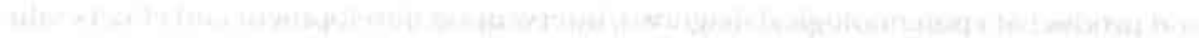

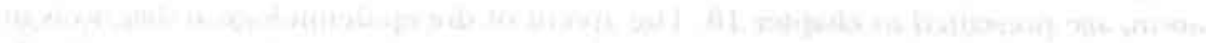

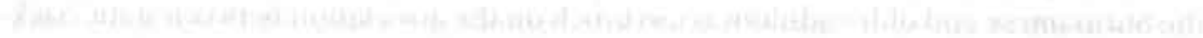

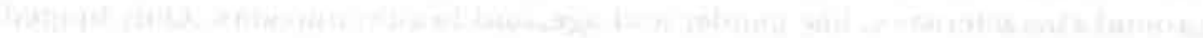

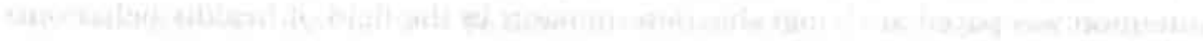

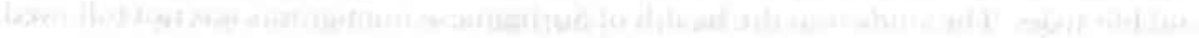

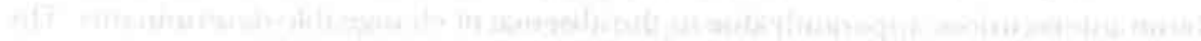

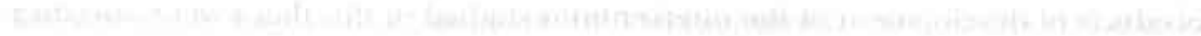

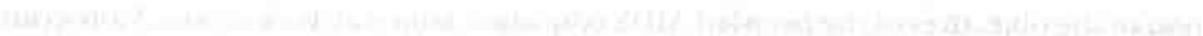

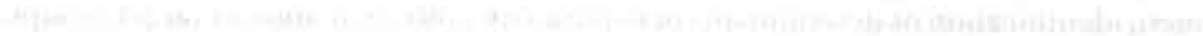

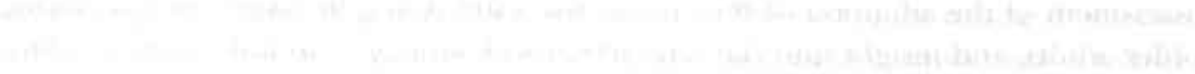

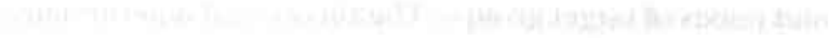

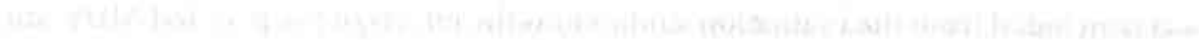

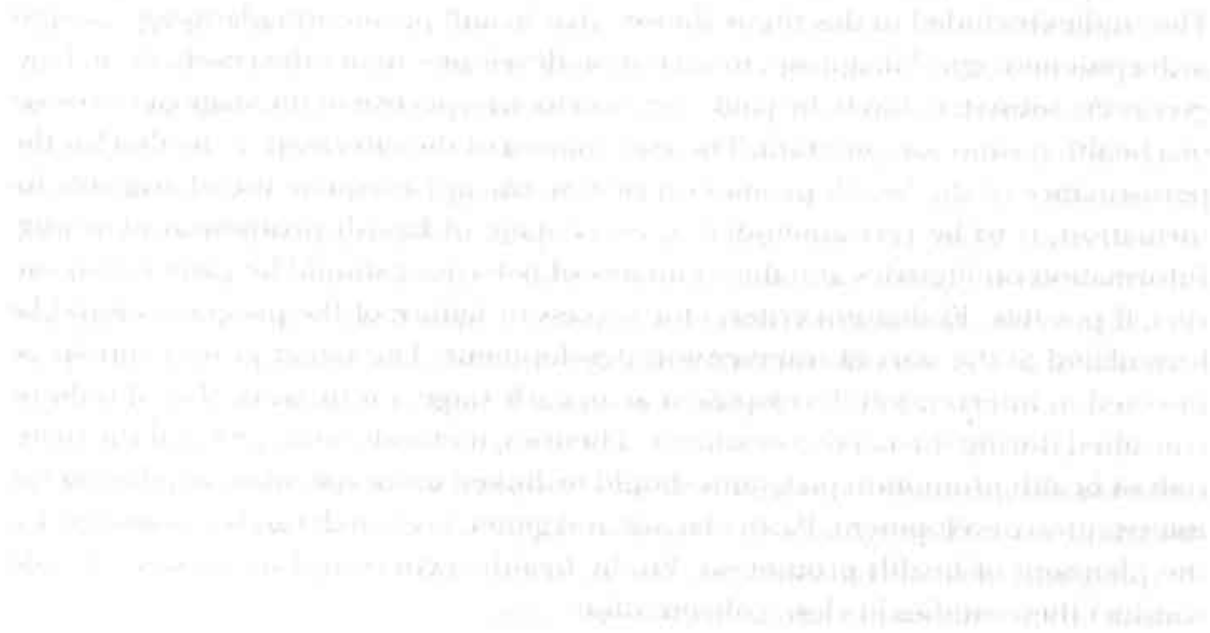




\section{Samenvatting}

Dit proefschrift bevat een aantal empirische onderzoeken op het terrein van de bevordering van de gezondheid van migranten en ouderen. Het doel van deze onderzoeken was een bijdrage te leveren aan de planmatige voorbereiding en uitvoering van gezondheidsbevorderingsprogramma's voor deze doelgroepen. Gezondheidsbevordering wordt gedefinieerd als de geplande combinatie van voorlichting, beleid, regelgeving en organisatie, ten gunste van leefomstandigheden die de gezondheid van individuen, groepen of buurten positief beinvloeden. Planning wordt in dit proefschrift gezien als een systeem bestaande uit de subsystemen inzichtvorming, besluitvorming en actie. In dit proefschrift worden de volgende subsystemen van planning van gezondheidsbevordering beschreven: epidemiologische diagnose, interventie-ontwikkeling en effectevaluatie. Bovendien worden het object en product (aspectsystemen) van gezondheidsbevordering bestudeerd. Het proces van hoe gezondheidsbevordering tot stand komt heeft in dit proefschrift geen aandacht. De vraagstelling van het proefschrift is: wat is het object en product van de subsystemen van planning van gezondheidsbevordering, te weten epidemiologische diagnose, interventie-ontwikkeling en effectevaluatie, gericht op migranten en ouderen?

In hoofdstuk 1 wordt een nadere toelichting gegeven op planning van gezondheidsbevordering en zijn subsystemen. Gezondheidsvoorlichting wordt onderscheiden van gezondheidsbevordering. Gezondheidsvoorlichting is gericht op de vrijwillige verandering van gedrag ten gunste van de gezondheid van individuen, door middel van leerervaringen. Gezondheidsbevordering in brede zin is zowel gericht op het veranderen van gezondheidsgedrag, als op omgevingsfactoren. In de onderzoeken van dit proefschrift wordt aandacht besteed aan omgevingsfactoren, wanneer deze de gedragsverandering van individuen, en daarmee de gezondheid indirect beinvloeden. Vier modellen van planning van gezondheidsbevordering worden behandeld: 'PRECEDE-PROCEED' van Green en Kreuter, 'Diffusion of innovations' van Rogers, het 'Community health promotion model' van Bracht en Kingsburry, en 'Intervention Mapping' van Bartholomew, Parcel en Kok. De modellen verschillen wat betreft het accent op de subsystemen en aspectsystemen van planning. 'Intervention Mapping' is het meest complete model, met aandacht voor zowel het object, proces als product van epidemiologische diagnose, interventieontwikkeling en effectevaluatie.

Het epidemiologisch diagnostisch onderzoek ten dienst van gezondheidsbevordering kan worden gekenschetst als descriptief en particularistisch. De prevalentie van gezondheidsproblemen en determinanten in een plaats- en tijdgebonden onderzoekspopulatie wordt beschreven. Onder het subsysteem van interventie-ontwikkeling is in dit proefschrift tevens begrepen de voorlichtingsdiagnose van determinanten van gedrag. Interventies dienen gebaseerd te worden op theoretische inzichten van gedragsverandering. Voorbeelden van theorieēn zijn het ASE (Attitude, Eigen effectiviteit en Sociale invloed) model van gedragsverandering, en theorieën met betrekking tot 'peer educa- 
tion: Het is tevens van belang de doelgroep bij het ontwikkelen van interventies te betrekken. Evaluatie van de effectiviteit van de interventies volgens de onderzoeksopzet van de 'Randomized Controlled Trial' (RCT) levert de meest valide onderzoeksresultaten op. Echter, in de praktijk van gezondheidsbevorderingsinterventies is het niet altijd mogelijk aan de voorwaarden van de RCT te voldoen. Alternatieven zijn de randomisatie van groepen of buurten, en het in combinatie toepassen van verschillende onderzoeksmethoden.

\section{Migranten}

Hoofdstuk 2 bevat het onderzoek naar de sterfte, de ervaren gezondheid en het gerapporteerd voorzieningengebruik van Surinaamse inwoners van Rotterdam. Uit de analyse van sterftecijfers kon worden geconcludeerd dat in zijn algemeenheid bij Surinamers een significante oversterfte kon worden waargenomen, in vergelijking tot Nederlanders. De sterfte was vooral hoger bij Surinaamse mannen tussen 15 en 34 jaar en Surinaamse vrouwen tussen 55 en 74 jaar. Aan steekproeven van Rotterdamse inwoners met de Nederlandse nationaliteit van 16 tot en met 75 jaar werden in post-enquêtes vragen voorgelegd over ervaren gezondheid en voorzieningengebruik. Meer Surinamers dan Nederlanders beoordeelden de gezondheid als matig tot slecht en meer Surinamers hadden de afgelopen twee maanden één of meer keren de huisarts geraadpleegd. Nader onderzoek dient te worden gedaan naar doodsoorzaken en achtergronden van gezondheidsproblemen bij de Surinamse bevolkingsgroep.

In het project Voorlichting Eigen Taal en Cultuur (Vetc) wordt Aids-voorlichting gegeven door 'peer-educators'. In hoofdstuk 3 is het onderzoek opgenomen naar de doelstellingen van de Aids-voorlichting voor de Turkse en Marokkaanse doelgroep en naar determinanten van condoomgebruik, teneinde aanbevelingen te kunnen doen voor de voorlichtingspraktijk. Uit kwalitatief onderzoek kwam naar voren dat de doelstellingen lagen op het terrein van kennis over Hiv-overdracht, de inschatting van het risico op Aids, en condoomgebruik. Uit registratie-onderzoek bij 48 voorlichtingsbijeenkomsten in koffiehuizen en moskeeēn bleek dat bij Marokkanen condoomgebruik meer aandacht kreeg dan bij Turken. Bij Turken kreeg de kennisoverdracht over Hiv-transmissie de meeste aandacht. Aan de bezoekers van koffiehuizen en moskeeën werd vooraf aan de voorlichting een vragenlijst voorgelegd, teneinde de determinanten van condoomgebruik te onderzoeken. Misverstanden rond transmissie van Hiv en opvattigen over het risico op Aids voorspelden de intentie tot condoomgebruik. Bij gehuwde mannen en mannen boven 30 jaar waren bovendien de barrière van verminderde satisfactie bij condoomgebruik en de eigen effectiviteit determinanten van intentie tot condoomgebruik. Aanbevolen werd om in de AIDS-voorlichting aan Turkse en Marokkaanse mannen aandacht te blijven besteden aan verandering van opvattingen over overdracht van Hiv en het risico op Aids, de discussie over condoomgebruik een duidelijke plaats te geven, en bij subgroepen aandacht te besteden aan eigen effectiviteit. Gezien de afwezigheid van een verband met de determinanten bij ongehuwden en jongeren, werd geadviseerd 
om bij deze groepen nader onderzoek te doen naar de motieven voor condoomgebruik.

Het effect van de 'peer' voorlichting voor Turksen en Marokkaanse mannen op de ervaren dreiging van Aids en opvattingen over condoomgebruik staat beschreven in hoofdstuk 4. Een vergelijking werd gemaakt tussen de experimentele groep die na de voorlichting een vragenlijst invulde en de gematchte controlegroep die vooraf aan de voorlichting de vragenlijst invulde. De voorlichting had tot effect dat misverstanden rond Hiv-transmissie verminderden en opvattingen over het risico op Aids realistischer werden. Binnen subgroepen werd een effect gevonden op de opvattingen over condoomgebruik. Bij mannen van 30 jaar en ouder was er een effect op het ervaren voordeel van de beschermende werking van condoomgebruik, bij ongehuwde mannen op de ervaren barrière van een verminderde satisfactie bij condoomgebruik, bij mannen die Aids-voorlichting in de eigen taal en cultuur belangrijk vonden op eigen effectiviteit, en bij Marokkanen op de intentie tot condoomgebruik. Geconcludeerd werd dat het Aids-Vetc project dient te worden gecontinueerd en dat de boodschap van de voorlichting meer dient te worden aangepast aan de behoeften van subgroepen.

\section{Ouderen}

Hoofdstuk 5 bevat het onderzoek naar de psychosociale gezondheid van ouderen in Rotterdam. Het onderzoek had tot doel aanbevelingen te doen voor preventie- en zorgbeleid. Een steekproef van zelfstandig wonende ouderen tussen 65 en 79 jaar werd een schriftelijke vragenlijst toegestuurd. Ongeveer eenderde deel van de ouderen ervoer psychosociale problemen. De prevalentie van psychosociale problemen was bij Rotterdamse ouderen hoger, wanneer werd vergeleken met normscores en met ouderen uit enkele andere steden. Risicogroepen waren alleenwonende mannen, vrouwen (al dan niet alleenwonend), ouderen met een lage sociaal economische status en serviceflatbewoners. Risico-indicatoren voor psychosociale problematiek waren problemen met het uitvoeren van algemene dagelijkse levensverrichtingen (ADL) en huishoudelijke activiteiten (HHA) en geringe sociale steun. De relatie met ontevredenheid over de woonsituatie werd beînvloed door de twee hiervoor genoemde risico-indicatoren. Het vaakst hadden ouderen met zowel psychosociale als ADL/HHA-problemen de laatste drie maanden contact gehad met hun huisarts. Activiteiten op het terrein van ADL/HHA en sociale steun, en gericht op de risicogroepen voor psychosociale problemen werden aanbevolen.

Het onderzoek naar de tevredenheid van intermediairen met de afstemming, ofwel 'linkage', tussen de plannen van het eenzaamheidsproject In Goed Gezelschap en de behoeftes van de doelgroep, wordt beschreven in hoofdstuk 6. De intermediairen waren zowel professionals als vrijwilligers, werkzaam op het gebied van gezondheidszorg en welzijn. In Goed Gezelschap was gericht op het voorkómen en verminderen van eenzaamheid bij ouderen $(55+)$. Tevens werd verbetering beoogd van de hulpverlening aan eenzame ouderen en van de samenwerking tussen intermediairen. 
In drie buurten werd geẽxperimenteerd met verschillende 'linkage' benaderingen. In de eerste buurt waar In Goed Gezelschap actief was, was sprake van een instrumentele benadering. De lokale organisaties werden gevraagd om een vooraf bepaald programma van activiteiten uit te voeren. In de twee andere opeenvolgende buurten, was er in toenemende sprake van betrokkenheid van intermediairen bij de opzet van het project. Dit werd een bottom up of democtratische benadering genoemd. De tevredenheid van de intermediairen werd door middel van schrifelijke vragenlijsten achteraf onderzocht. De grootste tevredenheid werd aangetroffen in de buurt waar een democratische 'linkage' strategie werd gebruikt, door de intermediairen expliciet te betrekken bij de opzet en organisatie van activiteiten. De behoefte aan ontspanningsactiviteiten met een ontmoetingsfunctie bleek groter, dan aan ondersteuningsgroepen en vaardigheidstrainingen. Met ander woorden de behoefte aan verandering van omgevingsfactoren was groter, dan aan uit onderzoek effectief gebleken activiteiten die gericht waren op verandering van gedrag. Geconcludeerd werd dat democratische 'linkage' strategieēn, zoals behoefteonderzoeken, locale actieplannen en interactie tussen programma-ontwerpers en -gebruikers, essentieel zijn voor de disseminatie van gezondheidsbevorderingsactiviteiten.

Hoofdstuk 7 bevat het onderzoek naar de kenmerken van Ridderkerkse ouderen die interesse toonden in de cursus Succesvol Ouder Worden, teneinde uitspraken te kunnen doen over de effectiveit van de cursus op bevolkingsniveau en over de gehanteerde disseminatie strategie. De cursus werd gegeven door 'peer' voorlichters, zogenaamde seniorenvoorlichters die zelf 55 jaar en ouder waren. De cursus was gericht op het bevorderen van de participatie van ouderen in de samenleving en op het verbeteren van het welbevinden. Tevens werden in de cursus gezondheidsthema's behandeld, gericht op gedragsverandering. Een voorbeeld is het verminderen van zorgen over vergeetachtigheid. Alle zelfstandig wonende ouderen tussen 55 en 79 jaar werden schriftelijk uitgenodigd om deel te nemen aan de cursus. $\mathrm{Zij}$ konden hun interesse kenbaar maken door middel van een antwoordkaart. Het percentage ouderen dat belangstelling toonde bedroeg $5,8 \%$. De interesse was het grootst onder vrouwen van 55 tot 64 jaar, ongehuwden en ouderen met een laag psychosociaal welbevinden. Mannen van 65 tot 79 jaar, vrouwen van 75 tot 79 jaar, ouderen met een lagere sociaal-economische status en zij die niet actief waren in hobby's of andere activiteiten, waren relatief gezien minder geĩnteresseerd. Binnen de groep ouderen met interesse werd een onderscheid gemaakt tussen ouderen die zich direct aanmeldden voor deelname en ouderen die nog afwachtten. Het waren vooral ouderen met een lage sociaal-economische status, met een laag welbevinden, met veel lichamelijke beperkingen en met een geringe eigen effectiviteit die zich direct aanmeldden voor de cursus. Geconcludeerd werd dat de cursus zal worden gecontinueerd, met speciale aandacht voor de subgroepen ouderen die minder belangstelling toonden. Aanbevolen werd om deze subgroepen bij de opzet van de cursus te betrekken. 
In hoofdstuk 8 wordt het effect geèvalueerd van de cursus Succesvol Ouder Worden op maatschappelijke participatie, de determinanten van maatschappelijk participatie (attitude, sociale invloed en eigen effectiviteit), ervaren sociale steun en welbevinden van de deelnemers tussen 55 en 79 jaar. De experimentele groep van ouderen die deelnamen aan de cursus werd vergeleken met een wachtlijst controlegroep. Op drie meetmomenten werden schriftelijke vragenlijsten afgenomen: vooraf aan de cursus $(t 0)$, direct na afloop ( $t 1)$ en na drie maanden ( $t 2)$. Op $t 2$ bleek de experimentele groep het in vergelijking tot de controlegroep minder eens te zijn met de opvatting in de samenleving dat ouderen een marginale positie hebben in de maatschappij (sociale invloed). De ervaren sociale steun en subjectieve beleving van de gezondheid van de deelnemers was op tl en $t 2$ significant verbeterd. Een effect op de attitude, eigen effectiviteit, maatschappelijke participatie en het algemeen welbevinden werd niet aangetroffen in het korte tijdsbestek van 3 maanden dat de onderzoekgroep werd gevolgd. Aanbevolen werd om nader onderzoek te doen naar de determinanten van maatschappelijke participatie en om aanvullend aan de cursus andere strategieèn ter bevordering van maatschappelijke participatie te organiseren.

Het effect van een voorlichtingsbijeenkomst over vergeetachtigheid in de cursus Succesvol Ouder Worden wordt beschreven in hoofdstuk 9. De doelstelling van de voorlichtingsbijeenkomst was de bezorgdheid van ouderen over alledaagse vergeetachtigheid en daaraan gekoppelde angst voor dementie weg te nemen. De kennis van de cursisten over factoren die het geheugen beïnvloeden was toegenomen. Ook ging van de voorlichting een effect uit op de eigen effectiviteit met betrekking tot het leren omgaan met vergeetachtigheid. Effecten op de attitude ten aanzien van het zich zorgen maken over vergeetachtigheid en op de ervaren sociale invloed van het taboe op vergeetachtigheid werden niet aangetroffen. Aanbevolen werd om nader onderzoek te doen naar de werking van determinanten op bezorgdheid over vergeetachtigheid. De inzet van 'peers' en aandacht voor eigen effectiviteit op verschillende levensterreinen in geheugentrainingen werd aanbevolen.

In hoofdstuk 10 worden de volgende conclusies getrokken ten aanzien de hoofdvraagstelling van het proefschrift betreffende het object en product van epidemiologische diagnose, interventie-ontwikkeling en effectevaluatie. De nadruk van de epidemiologische diagnoses bij Surinamers en ouderen lag te veel op de relatie tussen gezondheidsuitkomstmaten en onveranderbare achtergrondkenmerken, zoals geslacht en leeftijd. Onvoldoende aandacht werd besteed aan veranderbare gezondheidsgedrag of -leefstijl. Dit was mogelijk de reden waarom aan de epidemiologische diagnose bij Surinamers geen vervolg werd gegeven in de vorm van een interventie. De onderzoeken ter ondersteuning van interventie-ontwikkeling leverden de volgende producten op: specificatie van programmadoeleinden van Aidsvoorlichting aan Turkse en Marokkaanse mannen, identificatie van determinanten van condoomgebruik, differentiatie van doelgroepen, inschatting van de adoptie van de cursus Succesvol Ouder Worden door doelgroepen van ouderen, en inzicht in de tevredenheid van intermediairen met gehanteerde 'linkage' strategieẻn teneinde programmaplannen af te stemmen op behoeftes. Een onderbouwing van de 
determinanten van gedrag die onderwerp waren van het project seniorenvoorlichting was onvoldoende aanwezig. De conclusie ten aanzien van de effectevaluatie van de 'peer' voorlichtingsprojecten Aids-Vetc en seniorenvoorlichting was, dat slechts een gedeelte van de leerdoelen, ofwel verandering van determinanten van gedrag, werd bereikt. De bereikte effecten waren veelal klein tot middelmatig. Echter, bij de beoordeling van de effecten moet rekening worden gehouden met 'ruis' van onderzoek in de praktijksituatie, in vergelijking tot het ideaal van de RCT in een laboratorium situatie. Bovendien zijn de kosten van inzet van 'peer' voorlichters relatief laag.

De onderzoeken hebben laten zien dat de planning van gezondheidsbevorderingsprogramma's kan starten met epidemiologische diagnose, interventieontwikkeling of effectevaluatie. Ongeacht in welke fase er wordt gestart, dient er wel voldoende aandacht te zijn voor de andere subsystemen. Aanbevolen wordt om in elke fase van de planning van gezondheidsbevordering meer te anticiperen op de behoefte aan informatie benodigd bij de andere subsystemen, evenals meer gebruik te maken van de beschikbare informatie. Informatie over gezondheidsleefstijlen en determinanten van gedrag zou indien mogelijk moeten worden verzameld in surveys. Al aan het begin van interventie-ontwikkeling moeten evaluatie-criteria worden geformuleerd voor het succes of falen van een programma. Ook zou in een vroeg stadium de doelgroep meer moeten worden betrokken bij interventieontwikkeling, bijvoorbeeld wanneer de behoeftes van de doelgroep worden onderzocht bij de diagnose van gezondheidsproblemen. Bij interventieontwikkeling zouden voorlichtingsstrategieèn en -materialen meer moeten worden afgestemd op theorieën en methoden van gedragsverandering. Zowel particularistisch onderzoek als algemeen wetenschappelijk onderzoek, waarbij GGD'en en universiteiten intensief samenwerken, kunnen de planning van gezondheidsbevordering ondersteunen. 


\section{Curriculum Vitae}

Paul Kocken is geboren op 15 september 1963 te Boxmeer. Hij behaalde in 1981 het VWO-diploma aan het Elzendaalcollege te Boxmeer. Van 1981 tot 1985 studeerde hij Gezondheidswetenschappen aan de Rijksuniversiteit Limburg, thans Universiteit Maastricht. Hij volgde daar de afstudeerrichting Beleid en Beheer van Gezondheidszorgvoorzieningen. Na zijn studie Gezondheidswetenschappen werkte hij voor zijn vervangende dienstplicht bij de vakgroep Beleidswetenschap van de Rijksuniversiteit Limburg. Sinds 1988 is hij als onderzoeker werkzaam bij de Gemeentelijke Gezondheidsdienst Rotterdam e.o., alwaar het onderzoek opgenomen in dit proefschrift werd uitgevoerd. In 1992 volgde hij het 1 jarige post-academische opleidingsprogramma epidemiologie aan de Erasmusuniversiteit Rotterdam. Zijn werkterreinen betroffen de epidemiologie, openbare geestelijke gezondheidszorg en gezondheidsbevordering, met als doelgroepen ouderen, dak- en thuislozen en migranten. 
Epidemiologists, health educators, policy makers and research scientists are active from day to day in developing health promotion programs at the local level. This thesis comprises empirical studies in support of the planning of these programs. The studies are examples of planned epidemiological diagnosis, intervention development and effect evaluation in the fields of migrant groups, AIDS education, and interventions for older adults. The reader will learn about the object and product of today's practice of local health promotion and opportunities for improvement of program planning. 